UNIVERSIDADE DE SÃO PAULO

ESCOLA DE ENFERMAGEM

ALINE OLIVEIRA SILVEIRA

\title{
DEFININDO O PROJETO DE VIDA FAMILIAR: \\ a família na transição para o cuidado domiciliar da criança com necessidades especiais
}

SÃO PAULO 


\section{DEFININDO O PROJETO DE VIDA FAMILIAR: \\ a família na transição para o cuidado domiciliar da criança com necessidades especiais}

Tese apresentada à Escola de Enfermagem da Universidade de São Paulo para obtenção do título de Doutor em Ciências.

Área de concentração:

Cuidado em Saúde

Orientadora:

Profa $^{a}$. Dra . Margareth Angelo 
AUTORIZO A REPRODUÇÃO E DIVULGAÇÃO TOTAL OU PARCIAL DESTE TRABALHO, POR QUALQUER MEIO CONVENCIONAL OU ELETRÔNICO, PARA FINS DE ESTUDO E PESQUISA, DESDE QUE CITADA A FONTE.

Assinatura:

Data:

\section{Catalogação na Publicação (CIP) \\ Biblioteca "Wanda de Aguiar Horta" \\ Escola de Enfermagem da Universidade de São Paulo}

Silveira, Aline Oliveira

Definindo o projeto de vida familiar: a família na transição para o cuidado domiciliar da criança com necessidades especiais / Aline Oliveira Silveira. - São Paulo, 2010.

$249 \mathrm{p}$.

Tese (Doutorado) - Escola de Enfermagem da Universidade de São Paulo.

Orientadora: Prof ${ }^{a}$. Dra . Margareth Angelo

1. Pesquisa qualitativa 2. Enfermagem da família 3. Crianças 4. Doença Crônica 5. Cuidados domiciliares de saúde 6. Coleta de dados I. Título 
Nome: Aline Oliveira Silveira

Titulo: DEFININDO O PROJETO DE VIDA FAMILIAR: a família na transição para o cuidado domiciliar da criança com necessidades especiais de saúde.

Tese apresentada à Escola de Enfermagem da Universidade de São Paulo para obtenção do título de Doutor em Ciências.

Aprovado em:

\section{Banca Examinadora}

Prof $^{\mathrm{a}} . \mathrm{Dr}^{\mathrm{a}}$ Instituição:

Julgamento:

Assinatura:

Prof $^{a} . D^{a}$. Instituição:

Julgamento: Assinatura:

Prof $^{a}$. Dr $^{a}$. Instituição:

Julgamento: Assinatura:

Prof $^{\mathrm{a}}$. Dr ${ }^{\mathrm{a}}$. Instituição:

Julgamento: Assinatura:

Prof $^{\mathrm{a}} . \mathrm{Dr}^{\mathrm{a}}$. Instituição:

Julgamento: Assinatura: 
Ao Welitom 


\section{AGRADECIMENTOS}

A finalização deste trabalho representa a superação de intensos desafios que se apresentaram ao longo do caminho, ao escrever estes agradecimentos fui levada a olhar minha trajetória e revisitar pessoas significativas que fazem parte da construção minha história e, que, a sua maneira, contribuíram para o meu fortalecimento e enriquecimento pessoal e profissional.

Sinto-me abençoada pela família que tenho, fonte de amor e de fé, e sou grata a todos, em especial...

Ao Welitom, companheiro de todas as horas, na saúde e na doença, a quem tenho muito a agradecer, por ser quem é, pelo seu amor, por tudo que vivemos e conquistamos, pelo seu apoio preciso e incondicional, pela sua serenidade tranquilizadora, pela dedicação, pelo espírito bondoso e inúmeras qualidades que me fazem uma pessoa melhor a cada dia. Aprendi, mais que tudo, o verdadeiro significado do casamento. Não teria conseguido finalizar esse trabalho sem teu encorajamento e ajuda!

Aos meus pais, Marino e Susana, pelo amor, cuidado e apoio constante em todos os momentos de minha vida, pelo exemplo que são para mim e por ensinarem-me a manter o otimismo. Mãe, obrigada por suas orações! Pai, seu bom-humor tornou essa trajetória mais leve!

A minha querida irmã Marina, pelo carinho e ajuda na transcrição das entrevistas.

A minha querida avó Vera por seu cuidado e preocupação constante.

Ao meu tio Marco e sua família, pelo carinho e por estarem sempre próximos.

Sou, também, grata aos professores que partilharam dessa trajetória, em especial...

A Prof ${ }^{a}$ Dr $^{a}$ Elaine Damião e Prof $^{a}$ Dr $^{a}$ Lisabelle Mariano, por partilharem de suas experiências e pelo incentivo.

A Prof ${ }^{a}$ Dr $^{\text {a }}$ Regina Szylit Bousso, por contribuir com seus conhecimentos ao longo do curso e pelas sugestões no Exame de Qualificação. 
A Prof ${ }^{\mathrm{a}}$. Dr ${ }^{\mathrm{a}}$. Maria Aparecida Gaíva, por inserir-me na pesquisa com família e pelo incentivo.

A Prof ${ }^{\mathrm{a}}$ Dr ${ }^{\mathrm{a}}$ Myriam Pettengill, pelas sugestões no Exame de Qualificação.

A Escola de Enfermagem da Universidade de São Paulo pela oportunidade e por facilitar meu desenvolvimento na área de pesquisa.

As colegas e amigas do Programa de Pós-Graduação em Enfermagem, Maira, Mariana, Sandra e Nara, pela experiência partilhada e disposição em ajudar. Senti falta de vocês neste último ano!

Em especial sou profundamente grata à minha querida amiga Monika Wernet, tive o privilégio de conhecê-la nos anos de pós-graduação e agradeço por sua presença em minha vida, por sua ajuda, pelo encorajamento constante e pelas reflexões valiosas. Também, divido com você a satisfação desta conquista!

Aos funcionários da Escola de Enfermagem, especialmente da Biblioteca, da Secretaria do ENP e da Secretaria de PósGraduação, em especial a Silvana e Dayse, pelo atendimento gentil e ajuda.

Ao Hospital Universitário da Universidade de São Paulo, por possibilitar o desenvolvimento da pesquisa. Agradeço, também, a equipe do Programa de Assistência Domiciliar, em especial a Enfa. Terezinha, a Enf ${ }^{\text {a }}$. Beth e a Dra $^{\mathrm{a}}$. Eloisa pela acolhida e pelo apoio constante ao longo da coleta de dados. Aprendi muito com vocês!

A Dra . Débora Garcia, em nome de quem agradeço à Sociedade Brasileira de Medicina de Família, por possibilitar a coleta de dados da pesquisa. Sou grata por sua generosidade e pelo incentivo.

As colegas e amigas da Universidade Paulista, em especial a Ana Paula Zanelatto, Alexandra Silva, Aline Gulo, Miria Ribeiro, Thais Batoni e Sonia Lara, que tanto me apoiaram, nos momentos de dificuldade e assumindo minhas aulas.

Aos meus alunos de graduação e pós-graduação, pelo incentivo e pelo reconhecimento $\mathrm{e}$, sobretudo, pelas oportunidades de aprendizado.

A Eliane e ao Etelvaldo, pela bondade e pela ajuda com as referências.

Aos Amigos da Universidade Federal de Mato Grosso, em especial a Simone, a Naudia e ao Lando. 
As famílias deste estudo, pela disponibilidade em partilhar de suas experiências de vida e sofrimento, pela confiança e por oportunizarme aprendizados tão intensos e enriquecedores.

$E$, finalmente aos amigos de todos os momentos, pela alegria e força que me proporcionam simplesmente por serem que são e fazerem parte da minha vida, em especial...

Ao casal Daniely e Jorge, por tudo que fizeram por mim, pela presença constante em todos os momentos, pelo incentivo, mais que amigos, meus "compadres", a querida Ana Beatriz e a Isabela, por me fazerem esquecer por um momento a angústia da finalização da tese. Estendo este agradecimento a Dona Cida e Sr. Pedro, pela acolhida, pela generosidade e pela consideração que tem por mim. Meus grandes presentes em São Paulo!

Ao casal Marcos e Fabiana meus "compadres" mais antigos, por estarem próximos, pela torcida e companheirismo de sempre. A Camila, a Julia, ao Pedro e a minha querida afilhada Luana, pela alegria que proporcionam. Fabi, obrigada por sua companhia, por seus conselhos e por sua alegria, talvez não tenha demonstrado 0 quão próxima de você eu sempre estive! Meus grandes presentes em Cuiabá!

Ao Alexandre, pela sua generosidade, pela preocupação e bom humor, ao casal Rodrigo e Tânia, ao casal Selma e Paulo, ao casal Enrico e Janaína, ao casal Marcelo e Kátia, a Elizete, a Manuelle, ao Rodrigo Toffolli, pela gentileza com a revisão de português, ao Leandro (Cabelo), ao Sérgio Bezerra, a Karina, ao Sergio Fachin (Bob), pelos momentos de distração e pelo incentivo.

Deus se fez presente em meu cotidiano, me amparando e fortalecendo.

A todos meu reconhecimento e gratidão! 


\title{
Agradecimento Especial
}

\author{
À Prof $=$ Dr ${ }^{a}$ Margareth Angelo
}

Por acreditar em minha capacidade de produzir conhecimentos sobre família e pela compreensão nos momentos de dificuldade, por partilhar de sua sabedoria, pelos seus conselhos e suas orientações, que tanto contribuíram para minha formação como pessoa e como profissional. Terás sempre minha profunda admiração e respeito! 
"A medida que prestamos maior atenção ao cotidiano das famílias e nos envolvemos com sensibilidade e abertura para o sofrimento e a possibilidade, nos tornamos melhores pesquisadores, clínicos e seres humanos"

(Chesla) 
Silveira AO. Definindo o projeto de vida familiar: a família na transição para o cuidado domiciliar da criança com necessidades especiais. [tese]. São Paulo (SP): Escola de Enfermagem, Universidade de São Paulo; 2010.

\section{RESUMO}

A transição para o cuidado domiciliar de uma criança com necessidades especiais de saúde é um aspecto desejado e ao mesmo tempo desafiador por gerar mudanças definitivas na vida familiar. A presente pesquisa teve por objetivos compreender a experiência da família na transição para o cuidado domiciliar da criança com necessidades especiais de saúde e desenvolver um modelo teórico representativo dos padrões de interação familiar na transição para o domicílio. Trata-se de uma pesquisa qualitativa orientada pelo Interacionismo Simbólico, enquanto referencial teórico e pela Teoria Fundamentada nos Dados, como abordagem metodológica. A coleta de dados foi realizada através de entrevista em profundidade com onze famílias que estavam cuidando de suas crianças com necessidades especiais de saúde, em seu próprio domicílio. A compreensão teórica resultante da análise interpretativa permitiu a construção do modelo teórico DEFININDO O PROJETO DE VIDA FAMILIAR que integra os fenômenos PRESERVANDO A VIDA DA CRIANÇA e PRESERVANDO A VIDA FAMILIAR representativos das decisões e das ações familiares que conduzem a diferentes padrões interacionais que refletem o modo de organização do sistema familiar na experiência de transição para o cuidado domiciliar da criança com necessidades especiais de saúde. O modelo teórico apresentado destaca as forças e as fragilidades que determinam os padrões de enfrentamento no sistema familiar.

PALAVRAS-CHAVE: Pesquisa qualitativa. Enfermagem da família. Criança. Necessidades especiais. Cuidado no domicílio. Teoria Fundamentada nos Dados. 
Silveira, AO. Defining Family Life Project: family in transition to home care of child with special needs [thesis]. São Paulo (SP), Brasil: Escola de Enfermagem, Universidade de São Paulo; 2010.

\begin{abstract}
Transition to home care of children with special health needs is a wanted situation at the same time is a challenging for generating unquestionable changes in family life. This research aimed at understanding family's experience in the transition to home care of children with special health needs, and developing a theoretical model of family interaction patterns in the transition to home. It is about a qualitative research guided by Symbolic Interactionism, as theoretical framework, and by Grounded Theory, as methodological approach. Data collection was conducted through in-depth interviews with eleven families who were caring their children with special health care needs in their own home. Resulting theoretical understanding of interpretative analysis allowed the construction of theoretical model DEFINING FAMILY LIFE PROJECT integrating phenomena PRESERVING CHILD'S LIFE and PRESERVING FAMILY'S LIFE reflecting decisions and actions that lead to different family interaction patterns reflecting the organizing way of family system in transition experience to home care of children with special health needs. Theoretical model highlights strengths and weaknesses that determine patterns of coping in family system.
\end{abstract}

KEYWORDS: Qualitative Research. Family Nursing. Child. Special Needs. Home Care. Grounded Theory. 
Silveira AO. Definiendo el proyecto de la vida familiar: la transición de la familia al cuidado domiciliarios de los niños con necesidades especiales: [tesis]. São Paulo (SP), Brasil: Escola de Enfermagem, Universidade de São Paulo; 2010.

\section{RESUMEN}

La transición al cuidado domiciliar de un niño con necesidades especiales de salud es algo que desea y, al mismo tiempo, un reto para generar cambios definitivos en la vida familiar. Esta investigación tuvo como objetivo comprender la experiencia de la familia en la transición al cuidado domiciliario de niños con necesidades especiales de salud y desarrollar un modelo teórico de los patrones de interacción familiar en la transición al hogar. Se trata de una investigación cualitativa guiado por el Interaccionismo Simbólico como el marco teórico y la Teoría Fundamentada como enfoque metodológico. La colección de datos se llevó a cabo a través de entrevistas en profundidad con once familias que cuidaban de sus hijos con necesidades especiales de salud en su propia casa. La comprensión teórica resultante del análisis interpretativo permitió la construcción del modelo teórico DEFINIENDO EL PROYECTO DE VIDA FAMILIAR que integra los fenómenos PRESERVANDO LA VIDA DEL NIÑO y PRESERVANDO LA VIDA FAMILIAR que reflejan las decisiones y las acciones que llevan a diferentes patrones de interacción familiar que reflejan el modo de organización del sistema familiar en la experiencia de transición para el cuidado domiciliario de niños con necesidades especiales de salud. EI modelo teórico presentado destacan las fortalezas y debilidades que determinan los patrones de afrontamiento en el sistema familiar.

PALABRAS CLAVES: Investigación cualitativa. Enfermería de familia. Niños. Necesidades especiales. Cuidado domiciliario. Teoría Fundamentada. 


\section{LISTA DE ILUSTRAÇÕES}

Diagrama 1: Modelo Teórico DEFININDO O PROJETO DE VIDA FAMILIAR......218 


\section{LISTA DE QUADROS}

Quadro 1 - Exemplo de codificação inicial, linha a linha .......................... 100

Quadro 2 - Exemplo de categorização dos dados ................................. 101 


\section{LISTA DE SIGLAS}

\begin{tabular}{ll} 
CEI & Centro de Educação Infantil \\
CEP-HU & Comitê de Ética em Pesquisa do Hospital Universitário \\
CONEP & Comissão Nacional de Ética em Pesquisa \\
CRIANES & crianças com necessidades especiais de saúde \\
CSHCN & children with special health care needs \\
EMEI & Escola Municipal de Educação Infantil \\
GEENF & Grupo de Estudos de Enfermagem da Família \\
MEDLAR & Medicina Familiar e Preventiva \\
MS & Ministério da Saúde \\
PAD & Programa de Assistência Domiciliária \\
PAE & Programa de Aperfeiçoamento de Ensino \\
PED & Programa de Atendimento Domiciliário Pediátrico \\
POD & Programa de Oxigenoterapia Domiciliar \\
PROAFE & Programa de Atendimento à Família Enlutada \\
SISNEP & Sistema Nacional de Informação sobre Ética em \\
SOBRAMFA & Pesquisa envolvendo Seres Humanos \\
UCIN & Sociedade Brasileira de Medicina de Família \\
USP & Unidade de Cuidados Intensivos Neonatais \\
UTI & Universidade de São Paulo \\
& Unidade de Terapia Intensiva \\
\hline
\end{tabular}




\section{SUMÁRIO}

\section{CAPÍTULO I - INTRODUÇÃO}

1.1 PENSANDO E REPENSANDO FAMÍLIA E DOENÇA ................... 2

1.1.1 Motivações e evolução da questão da pesquisa.............. 2

1.2 CONTEXTUALIZANDO A QUESTÃO DA PESQUISA .................. 14

1.2.1 A criança com necessidades especiais de saúde e a família no contexto das políticas públicas.................... 14

1.2.2 A família na transição para o cuidado domiciliar da criança com necessidades especiais de saúde........... 20

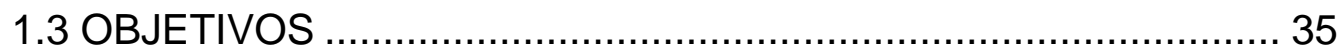

\section{CAPÍTULO II - REFERENCIAL TEÓRICO E METODOLÓGICO}

2.1 O INTERACIONISMO SIMBÓLICO COMO REFERENCIAL

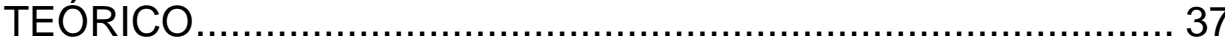

2.1.1 Conceito de símbolo...................................................... 41

2.1.2 Conceito de self ............................................................. 42

2.1.3 Conceito de mente .......................................................... 43

2.1.4 Conceito de assumir o papel do outro.......................... 45

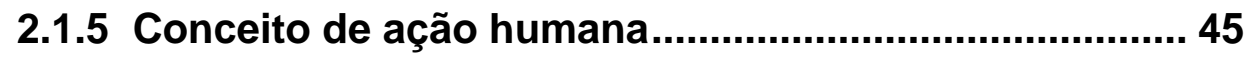

2.1.6 Conceito de interação social.......................................... 46

2.1.7 Conceito de sociedade ................................................. 48

2.2 O INTERACIONISMO SIMBÓLICO E A FAMÍLIA ......................... 50

2.3 A TEORIA FUNDAMENTADA NOS DADOS COMO ABORDAGEM METODOLÓGICA ............................................................... 53 


\section{CAPÍTULO III - O PROCESSO DE PESQUISA}

3.1 REALIZANDO A PESQUISA COM FAMÍLIA ............................ 59

3.1.1 Considerações éticas ..............................................62 62

3.1.2. Localização e acesso às famílias ............................... 63

3.1.2.1 Caracterização dos Serviços de Atendimento Domiciliar 66

3.1.3 O ambiente doméstico como contexto da pesquisa... 70

3.1.4 Coleta de dados .......................................................... 73

3.1.5 Caracterização das famílias participantes ................... 82

3.1.6 Análise dos dados .................................................... 100

\section{CAPÍTULO IV - RESULTADOS}

4.1 APRESENTANDO A HISTÓRIA E O UNIVERSO SIMBÓLICO FAMILIAR 105

4.2 COMPREENDENDO A EXPERIÊNCIA DA FAMÍLIA................ 133

4.3 O MODELO TEÓRICO ................................................ 215

\section{CAPÍTULO V - DISCUSSÃO DOS RESULTADOS}

5.1 RECONTEXTUALIZANDO A COMPREENSÃO DA EXPERIÊNCIA DA FAMÍLIA 224 
Introdução

\section{CAPÍTULO I}




\subsection{PENSANDO E REPENSANDO A FAMÍLIA E A DOENÇA}

\subsubsection{Motivações e evolução da questão da pesquisa}

Pensar e repensar a família e sua intersecção com saúde, doença, sofrimento e bem-estar de seus membros têm se tornado uma exigência crescente na enfermagem, tanto no âmbito da pesquisa, quanto do ensino e da prática.

A produção de instrumentos para a modificação das pesquisas de enfermagem - desde o nível individual para a unidade familiar, a extensiva e crescente produção de conhecimento sobre a família e a inclusão cada vez mais significativa da família nos diversos cenários de atendimento à saúde, bem como no ensino e no escopo de políticas públicas - tem indicado um movimento em direção ao cuidado centrado na família e na comunidade ${ }^{(1-3)}$.

Tal movimento evidencia que enfermeiras estão modificando seus padrões de prática, do cuidar focalizado apenas na doença e no indivíduo, para o cuidado que contemple a família também como paciente ${ }^{(4)} \mathrm{em}$ um contexto social.

Esse padrão é pautado na concepção de que a doença é um "evento de família" e que o enfermeiro tem como obrigação explorar e descrever o impacto da doença sobre a família, de ouvir e testemunhar as narrativas de doença, como aspecto central para o reconhecimento do sofrimento da família e, sobretudo, ajudar a família a lidar com as mudanças advindas da doença, aliviando ou curando o sofrimento. Ter o conhecimento e a habilidade para diminuir o sofrimento da doença, no seio da família, mais do que apenas prover educação e apoio para os membros, individualmente, está, definitivamente, no âmbito da prática de enfermagem ${ }^{(1)} \mathrm{e}$, portanto, pensar a família configura-se como uma exigência e, ao mesmo tempo, um desafio $^{(5)}$. 
Envolver a família como unidade de pesquisa ou de intervenção constitui-se, desse modo, um desafio, pois requer uma mudança de conceitos e de paradigmas para pensar-se a família sob uma perspectiva sistêmica e interacional ${ }^{(5)}$. Nessa perspectiva, é preciso refletir-se sobre a interação e a reciprocidade existente entre saúde, doença, sofrimento e funcionamento familiar. A interação entre enfermeiras e famílias e, também, considerar os amplos sistemas sociais dentro dos quais enfermeiras e famílias se inserem ${ }^{(2)}$.

O pensar a família sob essa perspectiva, entretanto, não ocorre de forma automática ou incidental. O pensar a família é uma habilidade crescente, adquirida quando, intencionalmente, focalizamos a aquisição de conhecimentos da família e desenvolvemos pesquisas sobre família, nos permitindo uma evolução conceitual e o movimento da sensibilidade "ingênua" para a sensibilidade teórica relativa à intersecção entre família, saúde e doença.

Partilhando de minha trajetória e motivações pessoais, acredito que meus primeiros estudos relativos à família, desenvolvidos ainda durante a graduação em enfermagem, partiram de uma sensibilidade ingênua, visto que não dispúnhamos de conhecimentos específicos da área de Enfermagem da Família, como conteúdos formais integrados à formação profissional.

Entretanto, a sensibilidade para as questões relacionais envolvidas nos encontros entre profissionais e famílias no contexto da doença e hospitalização da criança, introduzira-me na busca de conhecimentos sobre família, pautada, sobretudo, na grande preocupação de "como ajudar a família a lidar com os desafios gerados pela situação de doença da criança?". Essa questão tem acompanhando minha formação e atuação profissional, orientando o olhar sobre a relação entre doença e família e indicando os caminhos que tenho percorrido na busca de melhor conhecimento sobre a família. 
De acordo com os caminhos percorridos, tal proposição assumiu diferentes delineamentos e passou de uma questão ingênua, pautada em indicadores superficiais de necessidades familiares e no desejo de querer ajudar a família, para uma questão cada vez mais conceitual, que tem orientado o desenvolvimento de modelos teóricos com o potencial de contribuir para o desenvolvimento do pensamento interacional sobre a família e, desse modo, elevar o nível do cuidado à família, passando do cuidado linear ao relacional.

Acredito que o pensar a família, como unidade de pesquisa e de cuidado, não acontece repentinamente, é um processo por vezes lento, que depende de inúmeros fatores, cujos principais são os internos que tornam as pessoas diferentes em seu modo de ser, sensibilizadas para aspectos específicos e dispostas a vivenciar novas experiências e desafios.

O interesse em compreender e ajudar as famílias de crianças doentes surgiu durante os estágios de saúde da criança, ainda na graduação em enfermagem, acredito que sob uma forma de compaixão e de um ser solidário com a família, durante o cuidado da criança.

A aproximação com a realidade vivida pelas famílias fez que eu apreendesse a intensidade do impacto da doença sobre as vidas delas e como as famílias procuravam lidar com este problema na tentativa de manter ou restabelecer seu bem-estar, na maior parte das vezes de forma extremamente solitária e fragmentada, visto que o serviço permitia apenas um acompanhante com a criança doente e, em outros setores, como a Unidade de Cuidados Intensivos Neonatais (UCIN), restrições quanto ao tempo de permanência e participação dos pais com o cuidado do filho hospitalizado.

As restrições quanto à participação da família no cuidado da criança doente e hospitalizada passaram a fazer parte de minhas inquietações pessoais. Desse modo, meu primeiro estudo, pautado em preocupações relativas à família, fez parte de um amplo projeto sobre as condições de atendimento referente aos direitos da pessoa internada nos serviços 
públicos de saúde ${ }^{(6)}$ que teve como recorte os direitos da criança hospitalizada e da família, cujo desenvolvimento era baseado no questionamento sobre a consciência dos pais com respeito aos direitos que Ihes eram assegurados na legislação vigente. Esse estudo, desenvolvido sob uma perspectiva quantitativa, revelou o desconhecimento dos pais acerca dos direitos da criança hospitalizada e de seus próprios direitos à participação integral no cuidado durante a hospitalização.

Aos poucos, fui direcionando meu olhar para a família e para os aspectos pertinentes às restrições impostas à participação, as quais se somaram preocupações concernentes à relação estabelecida entre equipe de saúde e família. Esses aspectos relacionais me deixavam pouco confortável, me inquietavam ao mesmo tempo em que suscitavam diversos questionamentos.

O comportamento de constante aceitação dos familiares e a atitude da equipe que, ao contrário de aproximá-los, afastavam-nos ainda mais do cuidado da criança, ou, mesmo, geravam conflitos no ambiente hospitalar, fizeram-me perceber duas coisas: (1) a extrema fragilidade da família diante da situação vivenciada e (2) o despreparo dos profissionais em ajudar tais familiares em suas necessidades.

Os sentimentos negativos frequentemente expressos pelos familiares e sua evidente dificuldade em lidar com 0 advento da doença e hospitalização da criança, levaram-me a refletir sobre suas necessidades e preocupações e como estas poderiam ser atendidas pelos profissionais de saúde. Tais indagações foram acolhidas por uma de minhas professoras, Maria Aparecida Gaíva, a qual, na época, era uma das poucas pesquisadoras que desenvolvia um trabalho sobre família.

Direcionei tais questionamentos e suas respostas para um estudo desenvolvido com as mães de recém-nascidos prematuros e a equipe de saúde da unidade de cuidados intensivos neonatais (UCIN), focalizando a compreensão de como a família do recém-nascido prematuro e a equipe percebem o preparo para a alta hospitalar ${ }^{(7,8)}$. 
A relação estabelecida com os familiares e as respostas frente aos questionamentos emergentes propiciou uma maior reflexão sobre a importância da comunicação efetiva entre profissionais de saúde e família, visto que os resultados evidenciaram que o preparo para a alta se dava, principalmente, com o acompanhamento da rotina da UCIN pela mãe e centrava-se nos cuidados físicos do prematuro. Diante dessa evidência, passei a considerar os desafios para a construção de uma assistência centrada na criança e na família.

As incertezas e as dificuldades relacionadas à compreensão da família como uma unidade de cuidado permaneciam, mas estava motivada a aprender mais sobre família e doença, para que pudesse mudar o olhar de uma perspectiva de cuidado individual para uma que contemplasse a unidade familiar. Precisava aprender a pensar interacionalmente sobre família ${ }^{(5)}$.

Assim, a consciência de que precisava ampliar meu olhar estimuloume na busca por conhecimentos sobre família ao fazer o Mestrado do Programa de Pós-Graduação da Escola de Enfermagem, sob a orientação da Prof $^{a}$. Dr ${ }^{\mathrm{a}}$. Margareth Angelo. Tal atitude visava instrumentalizar-me conceitualmente para pensar a família, marcando o início da parceria entre orientadora e orientanda assim como de uma experiência pessoal e científica profundamente transformadora e enriquecedora.

No curso de mestrado, deu-se meu contato com a Enfermagem da Família como área específica de conhecimento e, por sua vez, com os referenciais teóricos e metodológicos para a compreensão da família, que passaram a orientar minhas reflexões, meu pensar família e minhas pesquisas com a família.

Cabe destacar, entre os referenciais teóricos que passaram a integrar meu olhar sobre a família, o Modelo Calgary de Avaliação e Intervenção na Família ${ }^{(1,9)}$, o Modelo de Crenças ${ }^{(10)}$, a Teoria de Sistemas ${ }^{(11)}$ e o Interacionismo Simbólico ${ }^{(12)}$ aplicados à compreensão da família. 
Assim, o início do mestrado e a participação no Grupo de Estudos de Enfermagem da Família (GEENF) ${ }^{1}$ representaram etapas importantes para aprofundar o conhecimento sobre a família como unidade de pesquisa e de cuidado da enfermagem assim como sobre a intersecção entre família e doença.

A descoberta de novos aspectos sobre a experiência de doença da família, de conceitos e de abordagens de cuidado centrados na criança e na família desvelou novos caminhos para a compreensão da família e, ao mesmo tempo em que modificaram e solidificaram minhas crenças, impulsionaram-me a buscar novas respostas para os problemas que atingem as famílias no cuidado de saúde pediátrico.

Assim, surgiram reflexões teóricas sobre o cuidado centrado na família e a concepção de sua limitada incorporação à filosofia assistencial dos sistemas de cuidado de saúde pediátricos ${ }^{(5)}$. Se, por um lado, a família estava inserida no contexto assistencial, por outro, não conhecíamos a extensão e nem como era envolvida como unidade de cuidado. Adicionado a esses aspectos, as lacunas de conhecimento sobre os significados atribuídos pela família às interações vivenciadas durante a hospitalização da criança e da necessidade de compreensão do processo de intervenção com família, conduziram ao questionamento "qual o significado que a família atribui às interações vivenciadas no contexto de hospitalização da criança?"

Esse estudo pautou-se na concepção sistêmica de família e de intervenção com a família. Sob essa perspectiva, a intervenção com a família é compreendida como um fenômeno interacional ${ }^{(13,14)}$ que ocorre e é atualizado em uma relação terapêutica estabelecida entre a família e o profissional ${ }^{(1)}$.

Desse modo, a intervenção envolve qualquer ação ou resposta do profissional que inclua ações terapêuticas e respostas internas cognitivo-

${ }^{1}$ O Grupo de Pesquisas de Enfermagem da Família (GEENF) foi organizado em 1995 sob a liderança da Profa. Dra. Margareth Angelo, na Escola de Enfermagem da Universidade de São Paulo. O grupo tem como propósito desenvolver conceitos, teorias e abordagens que fomentem uma prática clínica avançada junto com a família na experiência de doença. 
afetivas evidentes que ocorreram em um contexto relacional para afetar o funcionamento individual, familiar ou da comunidade pela qual o profissional é responsável ${ }^{(15)}$.

Outra concepção importante sobre a intervenção que orientou a compreensão do fenômeno estudado foi a de que intervenção efetiva é tudo aquilo que as famílias dizem fazer diferença em sua experiência de doença (16).

Utilizando o Interacionismo Simbólico como referencial teórico e a Teoria Fundamentada nos Dados como caminho metodológico para a construção do conhecimento sobre a família, desenvolvemos o estudo com famílias de crianças hospitalizadas, o que nos permitiu o desenvolvimento do modelo teórico "Buscando segurança para desenvolver suas competências", que integra os fenômenos "sentindo-se segura para assumir riscos" e "sentindo-se insegura para assumir riscos", representativo da experiência de interação da família durante a hospitalização da criança ${ }^{(17,18)}$.

A compreensão da experiência interacional da família nos permitiu identificar um conjunto de intervenções efetivas articuladas à experiência empírica da família, promotoras da segurança da família como elemento interacional que a conduz ao fortalecimento na experiência de doença e hospitalização da criança. Esse conhecimento nos permitiu, de forma especial, avançar na compreensão do componente relacional do cuidado centrado na família e proporcionar um caminho para a reflexão e aplicabilidade prática da abordagem.

Ao mesmo tempo em que o estudo possibilitou respostas, ele também nos conduziu a novos questionamentos sobre o cuidado centrado na família em uma situação de doença e sofrimento, visto que os resultados evidenciaram que este aspecto não é um componente sistemático e explícito do papel do profissional e que, desse modo, em muitas situações, o alívio do sofrimento ou alcance de bem-estar ocorre pelo próprio esforço da família. 
Tal concepção reforçou a ideia de que são muitos os desafios a serem superados para a transformação do cuidado centrado na família em uma prática prevalente. Visto que são inúmeras as dificuldades encontradas pelos enfermeiros e pelas famílias para se coenvolverem estratégias úteis que permitam consonância entre as expectativas e demandas de cuidado da família e as habilidades do enfermeiro em compreender e atender tais expectativas $(17,19,20)$.

Concordamos com Bell ${ }^{(21)}$ de que o conhecimento sobre os aspectos da experiência da família frente a situações de doença é importante para despertar a sensibilidade dos profissionais às respostas da família a tais eventos. No entanto, acredita-se que seja focalizando-se no processo interacional e de intervenções que se poderá fazer algo para, sistematicamente, ajudar as famílias.

A intervenção de enfermagem com família tem como meta efetuar uma mudança. As intervenções efetivas, capazes de gerar mudanças positivas na família, são aquelas nas quais exista um ajuste funcional entre intervenção proposta pela enfermeira e estrutura biopsicossocial e espiritual da família ${ }^{(1)}$.

Assim, a mudança terapêutica envolve sinergismo entre 0 conhecimento da família sobre sua experiência de doença e o conhecimento da enfermeira sobre o manejo da doença ${ }^{(22)}$.

O conhecimento e a habilidade para ajudar as famílias com as mudanças geradas pela doença estão definitivamente dentro do âmbito da enfermagem, entretanto o cuidado precisa evoluir do nível linear, focalizado no indivíduo, para o nível relacional, focalizado tanto no indivíduo quanto na família ${ }^{(2)}$.

A prática relacional com famílias experienciando doenças precisa refletir sua meta e essência que é reconhecer e aliviar o sofrimento, seja este físico, emocional ou espiritual ${ }^{(2,22)}$. Para tanto, existe uma necessidade de maior compreensão tanto dos processos interacionais quanto de 
intervenções com famílias experienciando sofrimento e dificuldades na situação de doença. É preciso determinar quais intervenções são mais efetivas para que tipo de família e para quais situações ou problemas específicos ${ }^{(2)}$.

Portanto, a pesquisa de enfermagem da família precisa evidenciar os processos pelos quais enfermeiros e famílias se engajam em uma relação de cuidado de saúde e como a família encontra alívio ou cura do sofrimento na experiência de doença.

Essas concepções são fundamentais para as mudanças de paradigmas de cuidar, para o avanço teórico da Enfermagem da Família e, consequentemente, para $\circ$ aperfeiçoamento da prática relacional com famílias vivenciando doenças e, desse modo, ampliar as possibilidades de apoiar a família em seus processos de enfrentamento.

Diante dos resultados trazidos no relatório de pesquisa de mestrado e as considerações com respeito à necessidade de ampliarmos a compreensão sobre a intervenção com famílias, dei continuidade no curso de Doutorado às reflexões, questionamentos e novas possibilidades de construção de conhecimentos sobre família.

No curso de doutorado, aprofundei o conhecimento sobre os instrumentos para a compreensão psicossocial da família e de intervenções com a família, especialmente articulando os de intervenção aos conceitos de competência familiar.

Nesse sentido, entendendo a competência familiar como um conjunto de habilidades aplicado pela família para lidar com as mudanças geradas pela doença, desenvolvemos, nos anos iniciais do curso de doutorado, um estudo que teve como questionamento: "que habilidades a família precisa aprender para incorporar e enfrentar as demandas da doença $e$ hospitalização da criança?” (23). 
Assim, identificamos cinco categorias de habilidades familiares: (1) adquirir segurança para cuidar da criança doente; (2) lidar com a solidão e o isolamento; (3) lidar com os rituais hospitalares; (4) administrar recursos financeiros limitados e (5) conformar-se à situação. Tais habilidades foram compreendidas como forças familiares mobilizadas para incorporar e enfrentar as mudanças geradas pela situação de doença e hospitalização da criança. As categorias de habilidades também revelaram importante interrelação com as particularidades de cada família, como estrutura, dinâmica, padrões sócio-culturais e de relacionamento, bem como com a situação de doença vivenciada e a forma como a família define tal situação ${ }^{(23)}$.

Este estudo reforçou tanto a evidência de que as famílias têm capacidade de lidar efetivamente com a situação de doença quanto à evidência de que as famílias têm necessidade de desenvolver novas habilidades para lidar com as mudanças trazidas pela doença e hospitalização.

Cabe ressaltar, entretanto, que a doença da criança ameaça profundamente o senso de segurança e de competência da família e que muitas famílias não conseguem se engajar sozinhas de forma ativa no processo de reestruturação e alívio do sofrimento $(17,18,24)$. Essas famílias devem ser compreendidas como sobrecarregadas e em situação de vulnerabilidade $(24,25)$ e, portanto, precisam de suporte e intervenção imediata da enfermagem.

As concepções apresentadas nos resultados dos estudos anteriores conduziram-me a novos questionamentos sobre como intervir com famílias, sobretudo em situações de cronicidade da doença e de continuidade do cuidado da criança no ambiente domiciliar, pois, apesar de a pesquisa ter sido conduzida no hospital, grande parte das crianças eram portadoras de condições crônicas e muitas famílias estavam vivenciando o preparo para o cuidado domiciliar. Diante disso, passei a questionar-me sobre como é feito o preparo da família e quais serão as conseqüências? Que decisões a família precisa tomar? Como a família se organiza para lidar com essa 
situação? $O$ que acontece com a vida familiar após a transição para o domicílio?

Esses questionamentos foram aprimorados ao longo das discussões no Grupo de Pesquisa de Enfermagem da Família, durante as leituras sobre a experiência da família e as reflexões que surgiram de meus encontros com as famílias nas supervisões clínicas dos estágios das disciplinas de Enfermagem da Família e de Saúde da Criança, onde atuei como docente por quatro anos. Tais questionamentos também surgiram ao longo dos estágios do Programa de Aperfeiçoamento de Ensino (PAE), que se deram como parte do programa da disciplina "Enfermagem no Cuidado da Criança e da Família na Experiência de Doença”, da Escola de Enfermagem.

Nessas ocasiões, os encontros com as famílias de crianças portadoras de condições crônicas e necessidades especiais de cuidado de saúde, levaram a diversos questionamentos sobre a intervenção com as famílias. A constatação de, ao menos, dois aspectos contribuiu para dar densidade as minhas reflexões e à questão de pesquisa como: (1) a peregrinação das famílias para o encontro dos recursos necessários para 0 cuidado da criança no contexto ambulatorial; (2) 0 isolamento de determinados membros da família, especialmente as mães, diante de uma hospitalização prolongada e o preparo para o cuidado domiciliar.

As crianças com necessidades especiais de saúde são clinicamente frágeis, dependentes de tecnologias médicas como meio de compensar a perda de uma função vital e de cuidados complexos e altamente especializados como forma de manter a vida. Essas crianças passam por hospitalizações prolongadas em unidades de cuidados intensivos e, sempre que possível, é feita a transição para o cuidado domiciliar. No entanto, tais crianças demandam serviços de saúde e sociais para além dos requeridos por qualquer outra criança como forma de manter o seguimento do cuidado no domicílio ${ }^{(26-28)}$.

Articulando tais aspectos ao conhecimento disponível na literatura de enfermagem sobre a experiência de famílias cuidando de crianças 
portadoras de condições crônicas e com necessidades especiais de saúde, identificamos que a transição do hospital para o domicílio, apesar de ser um aspecto desejado, é, ao mesmo tempo, um desafio importante na experiência da família, especialmente quando os recursos familiares são limitados e quando surge a situação de vulnerabilidade ${ }^{(29)}$. Portanto, essas famílias precisam de acompanhamento, avaliação sistemática, suporte e intervenção precoce.

A transferência de responsabilidade do cuidado para os pais e o tipo de suporte que será oferecido para o cuidado domiciliar não têm sido efetivamente negociado entre os profissionais e a família ${ }^{(30)}$. É comum a família não se sentir preparada, seja no âmbito técnico, de conhecimento, no financeiro e no emocional.

A transição do hospital para a casa, no que se refere ao preparo da família para lidar como sua nova condição de vida, ocorre muitas vezes de maneira solitária, sem o suporte dos profissionais, sendo a escassez de recursos e $o$ isolamento social expressivos na experiência dessas famílias (31).

A competência familiar é um aspecto que pode ser modificado severamente na situação de doença crônica e contínua necessidade de cuidados especiais devido às persistentes e múltiplas rupturas na vida cotidiana ${ }^{(32)}$. Desse modo, as famílias precisam, constantemente, manter um ajuste funcional entre desafios e recursos assim como nas diferentes dimensões da vida familiar ${ }^{(24,27)}$.

Diante de tais aspectos, fomos capazes de identificar que a experiência de transição da família de crianças com necessidades especiais de cuidado de saúde ainda é pouco compreendida, o que, por sua vez, pode estar contribuindo para a dificuldade de intervir de forma efetiva com essas famílias, visto que as evidências situam a experiência da família em termos de impacto e sobrecarga, mas ainda são escassas para a condução de intervenções sob uma perspectiva sistêmica e relacional. 
Desse modo, elegemos como questões do estudo: como a família vivencia a transição do cuidado da criança com necessidades especiais do hospital para o domicílio? Como a família se organiza para viver com a criança no domicílio?

Compreendendo a transição como um fenômeno interacional, acreditamos que podemos avançar no sentido de compreender os processos interacionais que facilitam ou dificultam a trajetória da família, como uma unidade funcional, na reestruturação, recuperação do sofrimento e na adaptação à situação de cuidado domiciliar da criança com necessidades especiais de cuidado de saúde. Tal conhecimento poderá contribuir para uma abordagem sistêmica da intervenção ajustada às particularidades dessa circunstância específica de vida familiar.

\subsection{CONTEXTUALIZANDO A QUESTÃO DA PESQUISA}

\subsubsection{A criança com necessidades especiais de saúde e a família no contexto das políticas públicas}

Os avanços nas tecnologias médicas e a incorporação destas nas áreas de terapia intensiva neonatal e pediátrica têm possibilitado um crescente aumento nos índices de sobrevivência entre neonatos de altorisco, crianças com malformações congênitas, traumas adquiridos entre uma ampla variedade de doenças anteriormente considerados incompatíveis com a vida.

Enquanto que presenciamos significativo e progressivo declínio da mortalidade infantil, também acompanhamos uma transição epidemiológica, evidenciada pelas complexas mudanças nos padrões de saúde e doença 
que acompanham essa população e suas implicações demográficas, econômicas, políticas e sociais ${ }^{(33)}$.

No que se refere à população pediátrica, tal transição tem se refletido no crescente número de crianças portadoras de condições crônicas, clinicamente frágeis, dependentes de dispositivos médicos como forma de compensar perdas de funções vitais e de cuidados de natureza altamente técnica, complexa e contínua como forma de manter a vida. Esse grupo de crianças é definido na literatura internacional como children with special health care needs (CSHCN) ${ }^{(26)}$. No Brasil, o conceito é introduzido no final da década de $1990^{{ }^{(34)}}$ como crianças com necessidades especiais de saúde (CRIANES).

As necessidades especiais de saúde dessas crianças geram demandas de cuidados classificadas em quatro grupos: de desenvolvimento, tecnológicos, medicamentosos e de cuidados habituais modificados (35). Dada a condição e a natureza do cuidado, essas crianças necessitam de serviços de saúde e sociais para além dos requeridos por qualquer outra criança, em geral, e por um período de tempo indeterminado $(26,35-37)$.

A incidência e a prevalência são desconhecidas em termos oficiais, devido aos diversos termos empregados para classificar esse grupo de crianças e a multiplicidade de condições clínicas que agrega. Entretanto, há um amplo consenso entre pesquisas desenvolvidas em diversos contextos específicos de que é crescente e expressivo o número de crianças com necessidades especiais de saúde cuidadas por suas famílias no ambiente domiciliar ${ }^{(38-45)}$. No entanto, estudos desenvolvidos em contextos brasileiros específicos, como no Rio de Janeiro, revelam que $74,2 \%$ dos bebês egressos da terapia intensiva neonatal apresentavam alguma necessidade especial de saúde; no sul do Brasil, o índice de necessidades especiais atribuídas a intercorrências no período perinatal foi de $58,5 \%{ }^{(45)}$.

A crescente transição das crianças com necessidades especiais para o cuidado domiciliar é apontado como conseqüência do movimento cada vez mais intenso em prol da desospitalização. Nesse âmbito, duas forças 
confluíram para a casa tornar-se uma alternativa cada vez mais aceita em vez do hospital: (1) aumento dos custos com a internação prolongada dessas crianças as quais, até pouco tempo atrás, eram confinadas ao ambiente hospitalar e "residentes" até a morte; (2) uma crescente consciência entre profissionais e famílias de que a casa representa o contexto ideal de cuidado, cujas questões de desenvolvimento e de qualidade de vida dessas crianças foram fatores considerados cruciais ${ }^{(46)}$.

O desenvolvimento de tecnologias adaptadas para o uso doméstico e as políticas públicas com ênfase no cuidado centrado na comunidade como forma de apoiar o seguimento domiciliar das crianças com necessidades especiais de saúde também têm contribuído para esse processo ${ }^{(46)}$.

Somados a esses aspectos, evidencia-se uma melhora significativa das taxas de sobrevivência de crianças que são clinicamente frágeis e dependentes de tecnologia, com a crescente capacidade de transferência de tecnologia médica e do cuidado para o domicílio ${ }^{(41)}$. Entretanto, cabe destacar que não é apenas a tecnologia que é transferida para o domicílio, mas, especialmente, os papéis e as responsabilidades são transferidos para a família ${ }^{(49)}$.

Com o crescimento desse grupo e crianças, políticas governamentais em países desenvolvidos têm reconhecido suas demandas e particularidades e provido a implantação de serviços de suporte à criança com necessidades especiais de saúde e sua família, como uma forma de apoiá-las na continuidade do cuidado domiciliar.

Nos Estados Unidos, país pioneiro na implantação desses serviços, o cuidado domiciliar para crianças dependentes de tecnologia foi implantado no início dos anos de 1980, data em que a primeira criança dependente de ventilação mecânica foi transferida para seu domicílio ${ }^{(50)}$. Desde então, o suporte ao cuidado domiciliar dessas crianças tem sido promovido como um ideal fundamentado nos princípios de normalização da vida da criança e de que a transição para o domicílio deve beneficiar tanto a criança quanto a

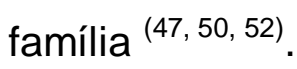


Assim, foram estabelecidos os critérios de elegibilidade para a alta dessas crianças, pautados nas condições sociais da família e de segurança suplementar à criança no domicílio. Destaca-se, nesse processo, o papel central do enfermeiro hospitalar, como profissional responsável pelo planejamento da alta, em assegurar o preparo da família e do ambiente domiciliar, sendo apontado como um recurso para a família e suas ações delineadas em torno do reforço educativo para a execução de cuidados complexos e de apoio à adaptação familiar ${ }^{(47,50)}$.

Além disso, há na figura da Enfermeira de Comunidade um papel de articulador dos diversos níveis de atenção à saúde e à família da criança com necessidades especiais, de modo a promover a interface entre a família como unidade de cuidado e o sistema de saúde ${ }^{(53)}$.

Acompanhando essa tendência, o Canadá implanta na mesma época a política nacional de suporte ao cuidado centrado na comunidade, para crianças com necessidades especiais de cuidado de saúde ${ }^{(54)}$. $\mathrm{Na}$ Inglaterra, as políticas de saúde têm promovido a cuidado no contexto da comunidade e como parte dessa tendência existe um reconhecimento específico da necessidade de transição do cuidado dessas crianças, do hospital para o domicílio, articulada com a prestação de serviços continuados $^{(55-57)}$.

Entre os serviços e recursos requeridos por essas crianças e suas famílias, inserem-se as linhas de financiamento para custeio das adaptações domésticas para a acomodação da tecnologia médica e a adequação às necessidades de cuidado da criança, a disponibilização de serviços de cuidados temporários e de apoio ao cuidador, a disponibilização de materiais de consumo, requeridos para a execução dos cuidados, de medicamentos e de equipamentos que a criança necessita, os serviços de transporte especial, os sistemas de referência para a continuidade dos tratamentos requeridos e a disponibilização de profissionais especializados responsáveis pela coordenação tanto dos serviços de saúde quanto dos sociais ${ }^{(48)}$. 
De forma adicional a tais políticas, têm sido delineados indicadores de uma "boa prática", disponibilizando equipes de enfermeiros pediatras comunitários para as crianças com necessidades especiais de saúde que vivam em suas casas e, também, para suas famílias ${ }^{(58)}$ e o desenvolvimento de serviços de cuidados paliativos ${ }^{(59)}$.

Nesse contexto, os atributos mais específicos para a prestação de serviços domiciliares têm sido claramente descritos, com destaque para a forte promoção do cuidado centrado na família e do conceito de parceria como um princípio norteador das relações entre os prestadores e usuários dos serviços ${ }^{(48)}$.

No âmbito das políticas públicas de suporte ao cuidado domiciliar, implantadas nos países desenvolvidos, as crianças com necessidades especiais de saúde e seus familiares possuem uma oferta variada de programas vinculados ao sistema de saúde que asseguram o bem-estar, o conforto, a segurança e o repouso dos cuidadores familiares. Sendo exemplos disso, o sistema cuidados temporários disponibilizados tanto na comunidade quanto no domicílio e a consulta de enfermagem da família ${ }^{(60)}$.

No Brasil, o benefício da prestação continuada de cuidado no domicílio é assegurado pela Lei Orgânica da Assistência Social ${ }^{(61)}$ por meio da qual é concedido recurso financeiro no valor de um salário mínimo à pessoa portadora de deficiência e cuja família seja incapaz de prover sua manutenção. O critério econômico para a elegibilidade ao recurso é a família cuja renda mensal per capita seja inferior a um quarto do salário mínimo, sendo, desse modo, assegurado às famílias de crianças com necessidades especiais, em situação de pobreza, recorrer a esse recurso para assegurar os custos de sobrevivência de sua criança. Não existe qualquer outro programa sustentável ou recurso público específico para crianças com necessidades especiais de saúde e suas famílias ${ }^{(28)}$.

Muitas crianças recebem alta hospitalar para o domicílio com demandas altamente complexas e ainda, como agravante, as famílias 
possuem recursos financeiros insuficientes ou limitados para arcar com os custos envolvidos ${ }^{(28,29,35)}$.

Em outras circunstâncias, quando há necessidade de sustentação da vida da criança, esta é mantida institucionalizada diante da condição social da família. Sendo comum, nesses casos, os familiares terem que recorrer a Vara de Proteção da Infância, na esfera municipal, para receber o apoio financeiro do Estado e assegurar as condições mínimas de implantação do cuidado em seu domicílio ${ }^{(35,60)}$.

Cabe destacar que no Brasil, temos presenciado significativos avanços no sistema de saúde e social, com a implantação do Sistema Único de Saúde, norteado pelos princípios de universalidade de acesso, descentralização e equidade ${ }^{(62)}$, do Programa de Saúde da Família, que em suas diretrizes concebe a família como unidade de cuidado de saúde ${ }^{(63)}$ e a implantação do Estatuto da Criança e do Adolescente ${ }^{(64)}$ que se configura como um marco no que se refere à proteção e promoção da infância, assegurando entre outros direitos fundamentais, o direito à saúde e à inclusão social.

Embora a legislação tenha avançado no campo do direito à saúde e ao bem-estar social e em estratégias de atenção à saúde da criança e da família, ainda não existe uma cultura de reconhecimento dos direitos da criança com necessidades especiais de cuidado de saúde e de sua família, por meio de uma oferta regular, sistematizada e organizada de sistemas de apoio social e de serviços de saúde especializados ${ }^{(60)}$.

O desafio no âmbito das políticas públicas brasileiras, no que se refere à continuidade do cuidado no domicílio, está na modificação da visão, na qual estas crianças e famílias não sejam consideradas portadoras de deficiências ou desvantagens ${ }^{(60)}$, mas, sim, como crianças e famílias com necessidades altamente complexas e que vivem desafios para a inclusão social e que possuem direitos como qualquer outro cidadão, sendo necessário ampará-las. 
Essa breve contextualização comparativa nos permite identificar as particularidades contextuais, que por sua vez influenciam não apenas a experiência das famílias, mas o tipo de pesquisa que é conduzida e seus achados, que muitas vezes se limitam a contextos ou serviços específicos. Também nos sugere pensar no nível de dificuldades que as famílias brasileiras enfrentam.

No entanto, cabe destacar que estudos de avaliação dos serviços de suporte ao cuidado domiciliar de crianças com necessidades especiais indicam que estes ainda são pouco desenvolvidos e deficientes em planejamento e, consequentemente, se tornam insuficientes e pouco efetivos em termos de apoio a família ${ }^{(65)}$. Como conclusão, a problemática da transição para o domicílio não se limita apenas ao Brasil.

\subsubsection{A família na transição para o cuidado domiciliar da criança com necessidades especiais de saúde}

A experiência da família vivendo com a criança com necessidades especiais de cuidado de saúde, retratada na literatura, releva o impacto multidimensional da situação na vida da criança e na vida familiar e, por outro lado, a fragilidade do apoio social e a ausência de serviços efetivos sensíveis às necessidades desse grupo.

As famílias de crianças com necessidades especiais de cuidado de saúde enfrentam constantes mudanças em suas vidas, diante da complexidade dos desafios, das dificuldades e dos estressores psicossociais e emocionais que acompanham essa situação. Entre estes aspectos destaca-se a realização de cuidados de natureza altamente técnica, complexa, contínua e intensiva compatíveis com a de uma formação profissional e a infinidade de responsabilidades e papéis assumidos pelos pais para cuidar dessas crianças no domicílio. Entre os aspectos relacionados à experiência da família cuidando da criança com necessidades especiais no domicílio, destacam-se as dimensões éticas e 
morais envolvidas nos processos de tomada de decisão e que perpassam a vida familiar; a dimensão social e a dimensão temporal, como aspectos globais da experiência que influenciam o funcionamento e a adaptação da família. Os conceitos de incerteza, de normalização e de isolamento social são fortemente associados ao nível de funcionamento familiar e de sofrimento experimentado pela família.

$\mathrm{Na}$ trajetória dessas crianças e suas famílias, a transição para 0 cuidado domiciliar no que se refere ao manejo da alta é considerado problemático tanto na perspectiva dos pais como dos profissionais de saúde e do serviço social ${ }^{(53)}$. A ausência de negociação de papéis tanto no hospital quanto no domicílio, de planejamento e de coordenação dos serviços direcionados à criança e sua família, bem como a intensa fragmentação dos sistemas de suporte são destacados como desafios adicionais no curso do cuidado da criança com necessidades especiais de saúde no domicílio, podendo gerar os mais variados desdobramentos na vida familiar ${ }^{(30,65-68)}$.

Estudos que abordam os aspectos envolvidos nas tomadas de decisões da família com respeito ao tratamento da criança, quanto ao suporte tecnológico e a escolha do local de provisão de cuidado da criança com necessidades especiais de saúde, revelam que os padrões éticos e legais de tomada de decisão estabelecidos nas instituições de cuidado de saúde visam o respeito à autonomia e à privacidade familiar ao garantir aos pais a autoridade sobre o bem-estar de sua criança.

O respeito pela escolha dos pais promove o valor da integridade familiar, permite a liberdade de identificação daqueles que poderão tomar as melhores decisões e reconhece o papel legítimo e constante dos pais na vida da criança ${ }^{(69,70)}$. No entanto, a tomada de decisão nessa circunstância apresenta-se eticamente desafiadora e pode gerar problemas complexos, que afetam não só a vida da criança, mas a dos profissionais de saúde, bem como alteram, de forma definitiva, a vida da família.

A decisão partilhada entre pais e demais membros da família com os profissionais de saúde, na qual os respectivos pontos de vista possam ser 
conciliados, é vista como a estratégia ideal em situações difíceis no sentido de promover a melhor escolha, pois a família depende dos conhecimentos médicos e de suas recomendações sobre o melhor curso possível de ação para sua criança e aqueles, por sua vez, têm a obrigação legal e moral de prover o suporte para a tomada de decisão familiar ${ }^{(70)}$.

A complexidade da condição da criança e do tratamento, a inexperiência da família com tomadas de decisão dessa natureza e dessa dimensão, as características sociais, religiosas, culturais e de linguagem são aspectos que devem ser considerados na abordagem familiar, podendo dificultar a comunicação e o entendimento entre o profissional e a família. $O$ entendimento que a família faz da situação e suas ações podem fundamentar-se muito mais em um prognóstico baseado em valores e crenças do que em estatísticas médicas ou resultados comparativos de outros pacientes ${ }^{(70)}$.

Muitas vezes são requeridos julgamentos e tomadas de decisão complexas no contexto de recursos materiais e de tempo limitados ${ }^{(71)}$, e as considerações éticas tendem a ser restritas a episódios críticos de tomada de decisão ${ }^{(72)}$. Cabe ressaltar que a capacidade de os pais absorverem informações é particularmente desafiada em situações de sobrecarga e choque emocional, o que pode gerar o sentimento de despreparo para a tomada de decisão e levar os pais a consentirem com as decisões médicas $(73,74)$.

A forma como o diálogo é estabelecido com a família e como as informações são transmitidas pode influenciar as decisões familiares, tanto encorajando quanto desencorajando a escolha pelo tratamento de suporte de vida e cuidado domiciliar ${ }^{(75)}$.

O estudo de Kirk ${ }^{(30)}$ mostra que os pais inicialmente estão em uma posição de fragilidade para negociar os papéis na provisão de cuidados com os profissionais, além de lidar com o estresse da doença e hospitalização e estarem em um território desconhecido, tornam-se dependentes dos profissionais para informação. Os sentimentos dos pais de dever e obrigação 
e seu forte desejo de cuidar da criança em casa fizeram que os pais aceitassem, inquestionavelmente, os papéis para facilitar a alta da criança, sem estarem totalmente conscientes das potenciais implicações em longo prazo, para eles e para suas famílias.

Tal processo passa, inclusive, por respeito e compreensão das preocupações dos pais em renunciar o cuidado do filho a outra pessoa, citando por vezes como razão a complexidade de tecnologia da qual a criança é dependente e a imprevisibilidade de sua condição ${ }^{(76)}$.

Em estudo que aborda a transição da criança dependente de tecnologia do hospital para o domicílio, destaca-se que questões éticas podem ser ocultadas pelos valores culturais dominantes, políticas institucionais, precedentes históricos e normas legais, as quais, ao centrarem-se no direito da criança a segurança, privam a família do direito à autonomia $^{(47,77)}$.

A complexidade dos aspectos envolvidos na tomada de decisão quanto à tecnologia de suporte de vida e quanto ao cuidado domiciliar deve ser considerada. Os interesses da família como um todo devem ser reconhecidos e negociados no processo de tomada de decisão ${ }^{(72)}$. As famílias devem ser preparadas para as consequências de suas escolhas, ao mesmo tempo em que deve ser assegurada a responsabilidade partilhada pela vida da criança e da família após a transição para o domicílio ${ }^{(70)}$. Tal concepção dos aspectos interacionais envolvidos nos processos de tomada de decisão podem reduzir os problemas vividos pelas famílias ao ficar em casa com a criança.

A análise conceitual do cuidado parental de caráter altamente técnico provido à criança dependente de tecnologia no domicílio desafia a visão prevalente de que os pais têm a obrigação moral de cuidar de seus filhos. Os estudos destacam que as famílias precisam de ajuda mais do que coação legal ou pressão para assumirem o cuidado de suas crianças em casa $^{(30,78)}$. 
Apesar dos dilemas envolvidos nas decisões de suporte de vida e nas decisões relacionadas ao ambiente de cuidado de crianças com necessidades especiais de saúde, a importância de apoiar o cuidado domiciliar é destacada, o qual é visto como forma de aliviar o intenso nível de adversidade que tais crianças e famílias encontram na hospitalização prolongada ou permanente ${ }^{(79)}$. Além disso, a necessidade da família de ir para casa com a criança se sobrepõe aos possíveis efeitos negativos que essa decisão possa acarretar à vida familiar ${ }^{(50)}$.

O sucesso do cuidado domiciliar, entretanto, irá depender da avaliação da criança e da família para essa opção, a avaliação do potencial da comunidade em oferecer os serviços que a criança e a família precisam e o desenvolvimento de um plano de cuidado compreensivo continuamente ajustado às demandas e à realidade de vida da criança e da família ${ }^{(47,80)}$.

As famílias são capazes de alcançar uma significante normalização em suas vidas ao ficarem em casa. Entretanto, isso envolve um processo altamente exigente e uma ampla variedade de recursos. Profissionais de todos os níveis ao longo do contínuo cuidado podem coordenar os esforços da família no sentido de facilitar a transição para o cuidado domiciliar ${ }^{(74)}$.

O apoio formal, especialmente da enfermagem, durante a transição do hospital para o domicílio, pelo estabelecimento da parceria com a família, pode facilitar a adaptação e fortalecer os membros da família, especialmente os pais, para assumirem as responsabilidades de cuidado da criança ${ }^{(47,50,}$ 81). A parceria é, portanto, o conhecimento, a habilidade e recurso intensivo e o ponto-chave no relacionamento, fundamental para a prestação efetiva de serviços ${ }^{(76)}$.

Apesar de todas as recomendações com respeito ao processo de transição e dos benefícios do cuidado domiciliar para a criança, este ainda permanece intensamente desafiador, visto o nível de estressores que são colocados sobre a família e as ilimitadas responsabilidades assumidas pelos pais. Embora o cuidado e a promoção de um ambiente social que otimize 0 crescimento, o desenvolvimento e o bem-estar humano seja um componente 
autêntico da parentalidade ${ }^{(82)}$, este conceito assume diferentes dimensões e significados quando a criança possui necessidades especiais de saúde.

A transformação do significado cultural da casa e a natureza do cuidado provido à criança influenciam a construção da parentalidade da criança dependente de tecnologia ${ }^{(49)}$. A casa torna-se medicalizada. $O$ espaço familiar é dominado pela tecnologia e pela presença contínua ou frequente de profissionais de saúde ${ }^{(29,49,83)}$.

Nesse contexto, os pais desempenham papéis multifacetados, que envolvem tanto o manejo da complexa condição clínica da criança como a negociação de serviços de suporte domiciliar, gerando nos pais uma identidade social ambígua ${ }^{(49,83,84)}$.

Adicionalmente às atividades naturalmente associadas à parentalidade, os pais desempenham uma ampla variedade de procedimentos clínicos tradicionalmente pertencentes ao domínio profissional, os quais, além de habilidades técnicas, exigem dos pais estratégias cognitivo-emocionais para lidarem com a ambiguidade entre prover conforto e proteção e infringir dor ao próprio filho além de preservar a identidade parental. Desse modo, a parentalidade é construída envolvendo tanto a dimensão parental quanto a dimensão profissional. Os pais manejam essa tensão de forma a definirem a si mesmos como pais ${ }^{(49)}$.

Essa definição é fundamentada no relacionamento que constroem com a criança e no conhecimento único e individualizado que possuem sobre seu próprio filho, que se estende além do conhecimento científico sobre a condição clínica ou sobre o tipo particular de suporte tecnológico que a criança depende ${ }^{(49)}$. Tudo isso transformam os pais em experts em relação à criança deles e a experiência de cuidar o que, muitas vezes, justifica a postura dos profissionais de saúde de depositarem nos pais a total responsabilidade pelo cuidado, deixando pouco espaço para a negociação e o diálogo ${ }^{(85,86)}$. 
A forma como a parentalidade é construída em condições de alto nível de incerteza é abordada em um estudo com pais de crianças portadoras de doenças ameaçadoras à vida ${ }^{(87)}$. Nesse estudo, os pais definem seu papel protetor como parentalidade extraordinária, que envolve um esforço para além dos requeridos na parentalidade típica, de forma a assegurar a sobrevivência da criança e proteger o próprio self, preservando a si mesmos como pais e como um casal. A construção da parentalidade, nesse estudo, é caracterizada como um "assunto de família" (87:834), evidenciado pela cooperação entre os pais e o envolvimento dos avôs como fatores determinantes para a minimização das tensões e dos conflitos envolvidos em tal processo.

A parentalidade extraordinária ${ }^{(87)}$ ou a parentalidade de crianças com necessidades especiais ${ }^{(84)}$ envolve um alto nível de contínua adaptação. Os pais se veem no constante movimento de aprender a manejar novos papéis, muitos dos quais se sentem despreparados para assumir. A natureza e 0 processo de paternidade são reestruturados para 0 atendimento dos múltiplos desafios e tem consequências em toda a família ${ }^{(84)}$. Os pais vivem uma tensão constate e intensas dificuldades para manter o equilíbrio dinâmico entre o assegurar as necessidades de cuidado, o normalizar a vida da criança e o atender as demandas da família ${ }^{(84,87)}$.

As responsabilidades dos pais correspondem a uma ampla variedade de atividades complexas e invisíveis ${ }^{(84)}$. Entre as crianças dependentes de tecnologia de suporte de vida, o cuidado altamente técnico e especializado se torna o aspecto mais visível e de maior reconhecimento, tanto entre os profissionais quanto entre o público leigo. Entretanto, para muitos pais e famílias, o aspecto tecnológico do cuidado é visto como de menor importância, os pais tornam-se especialistas no cuidado ${ }^{(29)}$ e integram essa função de forma quase automática em suas vidas. Por outro lado, os aspectos invisíveis do cuidado incluem o monitoramento dos sintomas da criança, a antecipação de estratégias adaptativas, o facilitar e o monitorar o sucesso da criança em situações sociais e o negociar com os setores de saúde, educação e de serviço social ${ }^{(84)}$. 
Os papéis administrativos e políticos desempenhados pelos pais permanecem trabalhosos e problemáticos diante das novas situações e desafios que, constantemente, surgem na vida familiar. Os pais ressentemse do tempo, do esforço e da energia emocional que necessitam empregar em tais funções. No entanto, esta é a parte mais invisível de seu papel de cuidadores ${ }^{(84,88)}$.

Cabe destacar que, quanto maior a experiência dos pais com suas responsabilidades de cuidado, mais invisíveis e tidos como garantidos se tornam seus esforços. Isso coloca os pais em uma situação de risco para adquirir cada vez mais responsabilidades até vacilarem em manter a carga do trabalho ${ }^{(84)}$.

O significado do papel parental para mães de crianças com necessidades especiais em situações de incerteza e de dependência tecnológica é descrito como um processo de vigilância constante ${ }^{(89)}$ e de envolvimento absoluto ${ }^{(90)}$. Além disso, as mães enfrentam complexas obrigações ao lutar para manter a personalidade e os valores de sua criança (91).

As ações de cuidado são priorizadas pela mulher em seu cotidiano existencial. No entanto, as práticas aprendidas na socialização feminina não são suficientes para atender a complexidade dos cuidados exigidos pelas crianças com necessidades especiais de saúde. Para essas mães, o cuidado de sobrevivência assume um caráter "sobrenatural e singular", que exige um esforço para além de sua capacidade natural de cuidadora e que, ao mesmo tempo, mantém a singularidade ao adquirir um caráter protetor à medida que vai tecendo seu próprio estilo de cuidar ${ }^{(92)}$.

As cuidadoras expressam uma necessidade contínua de aliar seu próprio estilo de cuidar à prevenção de danos, à minimização de riscos e à vigilância constante. Essas mulheres aprendem suas práticas de cuidar na interação com os profissionais, com o tempo e na intensidade de convivência com a condição da criança ${ }^{(92)}$. 
Ao enfocarmos os benefícios do cuidado provido pela família à criança é evidente a expressiva melhora na expectativa e na qualidade de vida de crianças clinicamente frágeis e dependentes de tecnologia cuidadas no ambiente doméstico ${ }^{(41)}$.

Além disso, estudos que abordam a perspectiva da criança, ainda que de forma restrita, revelam que essas crianças alcançam significativo nível de bem-estar e normalização em suas vidas devido aos esforços extraordinários empreendidos por seus pais. As crianças tornam-se bem adaptadas à tecnologia e a seu ambiente social. A dependência tecnológica não é vista como um problema pelas crianças e, sim, como algo que as ajuda a restabelecer sua independência ${ }^{(93)}$. As crianças veem a si mesmas como normais e expressam o desejo de serem tratadas como uma criança normal ${ }^{(94)}$.

Por outro lado, à medida que inúmeros benefícios são incorridos à vida da criança ao ser cuidada em casa pela família, eles podem não atingir a mesma proporção quando consideramos as consequências geradas para os demais indivíduos que compõem a unidade familiar e para a família como um todo.

A experiência de cuidar de uma criança com doença crônica e necessidades complexas de saúde no domicílio gera uma mudança constante na vida familiar, acompanhada por intensas dificuldades, estressores e desafios ${ }^{(95)}$. Os estressores físicos, financeiros, emocionais e sociais, incluindo sentimentos de angústia e incerteza sobre a condição da criança, o isolamento social bem como a busca de normalização são legitimidades dessa experiência ${ }^{(41,47,94-97)}$.

Muitas famílias descrevem sua experiência como um contínuo processo de desenvolvimento e de adaptação ${ }^{(98)}$. A adaptação requerida por estas famílias envolve um complexo processo de negociação e de reestruturação da vida para assegurar as demandas de cuidado por longo tempo e que a casa permaneça com seu significado pessoal e cultural ${ }^{(99)}$. 
A dinâmica familiar é alterada de forma a incluir as demandas altamente complexas da criança e isso pode gerar conflito e ambiguidade de papéis e impacto nas relações conjugais ${ }^{(41)}$, os quais podem ser agravados quando as famílias enfrentam sobrecarga instrumental e financeira e vivem o isolamento social ${ }^{(41)}$.

As questões financeiras são preocupações comuns e fonte de angustia para as famílias de crianças com necessidades especiais de cuidado de saúde ${ }^{(47,100)}$. Tais questões impõem à família uma dificuldade legítima diante da escassez de recursos e geram um ciclo de estresse e esgotamento físico e emocional ${ }^{(29)}$.

A estrutura familiar, as intensas restrições, a dimensão da incerteza e a opressão ao funcionamento normativo da família podem ter um impacto negativo sobre a qualidade de vida familiar ${ }^{(89,101)}$. A análise da experiência da família no que tange ao cuidado da criança dependente de tecnologia no domicílio, sob uma perspectiva temporal, releva os múltiplos ritmos e rotinas, descritos como "tecnológicos", "sociais" e "naturais" ao redor dos quais as vidas das famílias estão estruturadas ${ }^{(42)}$.

O estudo evidencia que os ritmos e as rotinas da vida familiar variam em função do tipo e da quantidade de dispositivos tecnológicos utilizados pela criança, as necessidades individuais da criança e da quantidade de pessoas que proveem o cuidado técnico no ambiente domiciliar ou em outros contextos de cuidado de saúde. Entretanto, é afirmativo que o cuidado de uma criança dependente de tecnologia no ambiente domiciliar gera considerável demanda de tempo para a família e que a incompatibilidade com outras temporalidades sociais e institucionais tem implicações negativas na vida familiar ${ }^{(42)}$.

A tecnologia não apenas gera um novo tipo de infância para a criança doente, como também para os irmãos saudáveis. O foco e o planejamento das rotinas ocorrem em torno da criança dependente de tecnologia e os irmãos participam da divisão do trabalho, ordenando seus papéis e responsabilidades individuais em casa ${ }^{(42)}$. 
A natureza das atividades assumidas pelos irmãos varia ao longo do tempo, aumentando conforme a idade. Muitos irmãos iniciam participando das atividades domésticas, depois progridem tomando parte dos cuidados técnicos e de enfermagem, bem como supervisionando o irmão dependente de tecnologia, também cuidam de outros irmãos na ausência dos pais ou quando estes se encontram excessivamente ocupados com a criança doente, assim como levam e buscam na escola e em consultas hospitalares quando adquirem idade para tal função ${ }^{(42)}$.

Para os irmãos saudáveis, viver em uma família com uma criança dependente de tecnologia gera limitação de suas atividades sociais e afeta a frequência e o desempenho escolar, devido às consideráveis responsabilidades que assumem diante do regime de cuidado domiciliar da criança dependente de tecnologia. Também descrevem a atmosfera da casa como tensa e testemunham conflitos entre seus pais. Essa atmosfera é exacerbada pela falta de espaço pessoal, dentro de uma casa fisicamente limitada ${ }^{(42)}$. Tal perspectiva nos permite pensar no comprometimento do bem-estar psicossocial dos irmãos de crianças dependentes de tecnologia.

As limitações e as complexas demandas de tempo associadas ao cuidado de uma criança dependente de tecnologia, adicionadas à ausência de habilidades sociais podem isolar as famílias de suas fontes de apoio. Estudos evidenciam que com o tempo, à medida que a situação se torna mais estável, a natureza, a qualidade e a variedade das interações sociais da família diminuem, incluindo o apoio que recebe do sistema profissional de saúde ${ }^{(29,47,102,103)}$.

Com isso, ao longo do tempo, há um déficit crescente de lazer e de oportunidades de emprego. As famílias ficam limitadas ao domicílio, pois o transporte dessas crianças é complexo e de difícil acesso, o que, por sua vez, mantém o ciclo de isolamento social ${ }^{(72)}$.

A dimensão social da experiência dos pais revela que, comumente, eles se sentem confrontados com visões depreciativas acerca da condição da criança e com a desvalorização social da criança diante da escassez de 
serviços disponíveis $(74,84)$. Tais sentimentos podem ser reforçados pelos encontros com os profissionais que, constantemente, questionam o desejo da família em continuar mantendo a vida da criança ${ }^{(74)}$.

A vivência de alto nível de isolamento é atribuído a barreiras relacionadas em muitos aspectos de sua própria comunidade, mas também a uma escolha internalizada dos pais como um modo de proteger a criança e a si mesmos de encontros sociais ofensivos ${ }^{(84,104)}$.

Outro aspecto relacionado ao isolamento social, característico do viver dessas famílias e crianças, é a falta de informação ${ }^{(88)}$. Muitas famílias são "deixadas à própria sorte" para obter recursos na comunidade, e famílias com vida financeira mais desafiadora são mais limitadas em suas habilidades para manejar o estresse diário ${ }^{(29,74)}$.

As estratégias parentais utilizadas na busca de apoio social, no contexto do cuidado de crianças com necessidades especiais, variam de acordo com a consciência dos pais sobre a disponibilidade de recursos, de suas preferências pessoais ou expectativas em relação aos serviços e padrões de comportamento ${ }^{(105)}$.

Estudos que examinam o processo de busca e obtenção de apoio social revelam que os pais preferem sistemas informais ao contrário de sistemas formais de apoio social, que buscam ajuda apenas quando estão fracassando na resolução dos problemas e que se sentem angustiados e desmotivados quando os sistemas formais de apoio são julgados não efetivos e diante do desconhecimento dos profissionais sobre aspectos da dinâmica familiar ${ }^{(105)}$.

As famílias têm pouco ou nenhum acesso a cuidadores devidamente treinados que possam prover o cuidado técnico requerido pela criança, tanto dentro quanto fora de casa, de modo permitir aos pais e a toda a família oportunidade de pausas em suas atividades de cuidar nos momentos que sentirem tal necessidade $(103,106)$. Desse modo, questões instrumentais, como aumento do número de pessoas na família treinadas para cuidar da 
criança, a disponibilidade de serviços de cuidado especializado de curto prazo e a melhora no design e na acessibilidade a dispositivos médicos portáteis podem reduzir os efeitos negativos das demandas de cuidado sobre a família ${ }^{(42)}$.

A adaptação à condição da criança é vista como um intenso desafio para muitas famílias, sobretudo quando têm de lidar com seus limitados recursos pessoais e materiais para negociar com uma rede de serviços fragmentados e pouco efetivos. Essa é uma situação problemática para os pais, que se sentem responsáveis por assegurar que a criança receba os complexos serviços que necessita ${ }^{(74)}$.

As intensas e constantes demandas associadas ao cuidado de uma criança com necessidades especiais podem afetar adversamente a saúde física e mental dos cuidadores familiares ${ }^{(107-109)}$, especialmente entre as mães que diminuem, drasticamente, suas atividades de promoção da saúde pessoal ${ }^{(109,110)}$.

Os pais sentem-se sobrecarregados em função de suas responsabilidades como pais e cuidadores e, predominantemente as mães, podem entrar em fadiga emocional crônica experimentando medo, culpa, problemas conjugais e não-aceitação ${ }^{(27)}$ diante do estresse vinculado às necessidades de sua criança, tanto físicas quanto emocionais e de seu bemestar social ${ }^{(72)}$.

Conforme mostra Agazio ${ }^{(111)}$, um declarado realinhamento de papéis começa a ocorrer quando a mãe percebe que não é capaz de prover, sozinha, o cuidado da criança e quando, dentro dos casais, as mães tomam a iniciativa de preparar os pais para assumirem maior responsabilidade e participação no cuidado da criança e irmãos.

A intensidade das restrições financeiras e sociais bem como da sobrecarga instrumental e emocional podem resultar em significativos dilemas morais. Os pais podem experienciar tensões morais ao querer 
proporcionar a seu filho as vantagens de ser cuidado em casa, enquanto lutam com todos os conflitos pessoais e familiares de tal condição ${ }^{(74)}$.

A experiência dos pais com recém-nascidos com incapacidades funcionais severas revela que estas crianças tornam-se altamente dependentes de seus pais, os quais, por sua vez, podem ser pegos em um dilema moral entre o amor e a aversão por seu filho. A casa transforma-se em uma prisão da qual não conseguem visualizar as possibilidades de escapar ${ }^{(112)}$.

A experiência moral da família em viver em casa com a criança dependente de ventilação mecânica revela o fenômeno "vivendo diariamente com angústia e enriquecimento", o que reflete o impacto complexo e potencialmente opressor da situação na vida familiar. Essa tensão relacionase ao confronto com as responsabilidades parentais, a busca de normalidade, o conflito com valores sociais e a vivência de isolamento social, aspectos que determinam o constante questionamento da ordem moral de suas vidas. Os indivíduos descrevem suas vidas como uma situação injusta, para a qual não têm opções de escolha além de fazer o que deve ser feito. Entretanto, também identificam profundos enriquecimentos e recompensas em cuidar da criança em casa ${ }^{(74)}$.

A não conciliação entre a angústia e o enriquecimento é particularmente estressante para as famílias. Ao passo que ter o filho permanentemente institucionalizado ou "desligado" da ventilação e da vida sejam opções consideradas fora da realidade familiar, pois não imaginam suas vidas sem a experiência de cuidar da criança em casa ${ }^{(74)}$.

A perspectiva da família sobre sua experiência de cuidar por longo tempo de uma criança dependente de tecnologia, especialmente no que se refere à dimensão da incerteza na vida familiar, é representada pelo fenômeno "vivendo em um castelo de cartas" ${ }^{(89)}$. Nesse estudo, as famílias identificam que as áreas de desafio, de mudança e de crescimento pessoal incluem: (1) atribuir sentido à vida, (2) manejar a vida diária com a tecnologia e (3) manter o funcionamento da família. 
A autora afirma que as mudanças em qualquer uma dessas áreas altera o equilíbrio em todas as outras e força a família a se reestruturar, pois manter o funcionamento familiar é apontado como o principal desafio. No entanto, quando os pais são capazes de identificar aspectos positivos na dinâmica familiar, as habilidades organizacionais são aperfeiçoadas e a família desenvolve estratégias de enfrentamento efetivas, como encontrar tempo para a família e manter a conexão com a família extensiva, o que, por sua vez, atenuam o sentimento de isolamento e melhoram a qualidade da comunicação intrafamiliar.

Cabe destacar que ainda são poucos os estudos que abordem especificamente a experiência da família como uma unidade, na situação de transição para o cuidado domiciliar da criança com necessidades especiais. Concordamos com Carnevalle et al. ${ }^{(72)}$ que tal evento tem gerado um novo tipo de infância, de parentalidade e de vida familiar e que ainda é pouco conhecido, explorado e compreendido.

Tal cenário retratado na literatura nos permite afirmar que as famílias vivem desafios complexos e multifacetados e que nem sempre têm suas necessidades e expectativas atendidas pelos profissionais de saúde, que a negociação de papéis e a parceria são conceitos ainda imperceptíveis na prática e que esta interação pode ser fonte adicional de estresse para a família.

Entre todos os aspectos apresentados na literatura, podemos afirmar que esse evento tem sérias repercussões na vida familiar, visto que a experiência da família é situada em termos de sobrecarga e ausência de recursos, o que nos leva a pensar no alto nível de vulnerabilidade desse grupo familiar e na necessidade emergente de um cuidado centrado na família que integre todos os níveis de atenção à saúde da criança e da família.

Acreditamos que reflexões com respeito ao papel fundamental do enfermeiro na vida dessas famílias devam ser consideradas, visto o potencial que dispõe para assegurar a filosofia do cuidado centrado na 
família, no sentido de fortalecer a família como unidade de cuidado, nas áreas de enfrentamento, funcionamento familiar tanto instrumental quanto expressivo e a adaptação na situação de transição para o cuidado domiciliar da criança com necessidades especiais de saúde.

Para tanto, se faz necessário aprofundarmos a compreensão da experiência da família, especialmente focalizando nos padrões interacionais, para que a vida familiar com todas as suas complexidades, tensões e riquezas seja iluminada e os focos de intervenção reconsiderados. Essa, sem dúvida, é uma demanda e um desafio para a Enfermagem da Família.

\subsection{OBJETIVOS}

- Compreender a experiência da família na transição para o cuidado domiciliar da criança com necessidades especiais de saúde do hospital para o domicílio.

- Construir um modelo teórico representativo da experiência da família na transição para o cuidado domiciliar. 
Referencial Teórico e Metodológico

\section{CAPÍTULO II}




\subsection{O INTERACIONISMO SIMBÓLICO COMO REFERENCIAL TEÓRICO}

Ao definir-se como foco de estudo a experiência da família na transição para o cuidado domiciliar da criança com necessidades especiais de saúde, compreende-se a transição como um processo interacional, visto que a família é composta por pessoas em interação e atribui significados às experiências resultantes de suas interações ${ }^{(5)}$.

Para tanto, elegeu-se o Interacionismo Simbólico como perspectiva teórica para conferir sustentação ao desenvolvimento da pesquisa, orientar o processo de pensamento e de compreensão sobre os fenômenos, processos e padrões de interação familiar, aspectos estes extremamente compatíveis com a abordagem qualitativa de pesquisa com família ${ }^{(113)}$, quando se busca compreender o funcionamento interno da família e a essência da realidade de vida, construída por meio do significado.

O Interacionismo Simbólico se focaliza nos aspectos internos ou experienciais do comportamento humano. Sob essa perspectiva, os indivíduos ordenam seu mundo pelo processo de negociação e renegociação da realidade; fazem uso reflexivo de símbolos, interpretam e criam significados mais do que simplesmente reagem a eles. As pessoas constroem, julgam e modificam a si mesmas como objetos sociais em relação ao significado que atribuem à situação e as perspectivas e os planos emergem da interação social. Desse modo, as percepções da realidade são negociadas e, constantemente, criadas de acordo com as definições e significados atribuídos à situação e de acordo com o processo de resposta do Self negociada na interação com os outros que estão presentes na situação vivenciada ${ }^{(12)}$.

Essa perspectiva apresenta a visão das pessoas, da ação organizada e do ambiente como fluxos continuamente construídos e reconstruídos, pelos processos definitórios e interpretativos ${ }^{(12)}$. 
O ponto de partida do comportamento humano está no fato de que a interação é simbólica, ou seja, o significado está diretamente relacionado ao ato, o qual se dá, necessariamente, na interação ${ }^{(12)}$. O Interacionismo Simbólico implica na abordagem do significado, tanto no que concerne a emergência quanto ao funcionamento dele no contexto de interação social.

O Interacionismo Simbólico surgiu no século XVIII e tem suas raízes na Psicologia Social e Sociologia, sendo que George Herbert Mead, professor de filosofia da Universidade de Chicago, foi o primeiro a preocupar-se com o estudo aprofundado das inter-relações sociais, ampliando e difundindo, entre os anos de 1893 a 1931, os conceitos fundamentais do Interacionismo Simbólico ${ }^{(114)}$.

Os princípios fundamentais da interação simbólica, que contribuíram significativamente para a conceitualização da perspectiva interacionista, encontram-se na obra Mind, Self and Society, livro póstumo de Mead, publicado pela primeira vez em 1934, organizado e editado por Charles Morris, aluno de Mead ${ }^{(114)}$. No entanto, foi o sociólogo Herbert Blumer, discípulo de Mead, que apresentou de maneira sistemática os pressupostos fundamentais da abordagem interacionista simbólica, dando continuidade e maior elaboração ao trabalho de Mead.

De acordo com Blumer ${ }^{(12)}$, o Interacionismo Simbólico está fundamentado em três premissas básicas: (1) os seres humanos agem em relação às coisas (tudo que possa ser percebido) com base no significado que estas têm para eles; (2) o significado atribuído às coisas é derivado da interação social que os seres humanos estabelecem entre si; (3) os significados são modificados por meio de um processo interpretativo utilizado pela pessoa ao lidar com as coisas que encontra.

Diante do exposto, pode-se dizer que o Interacionismo Simbólico estuda o comportamento humano individual e grupal, tratando da questão vivencial, isto é, de como as pessoas definem os eventos ou a realidade e de como agem em relação a suas definições ou crenças. A perspectiva interacionista concentra-se na natureza das interações, na dinâmica das 
atividades sociais entre as pessoas, no significado dos eventos para as pessoas no mundo em que vivem, nos ambientes naturais de seu cotidiano e nas ações por elas desempenhadas ${ }^{(114)}$.

A descrição do comportamento humano, sob a perspectiva do Interacionismo Simbólico, é feita com base no ato social, em duas dimensões: a atividade manifesta, concebida como o comportamento externo observável, e a atividade encoberta, a experiência interna da pessoa $^{(12)}$.

Nenhum objeto no mundo (coisas, pessoas, eventos) possui significados intrínsecos ou valores inerentes. O significado é criado pela experiência, sendo por meio da interação com o objeto e com o próprio indivíduo que ele é definido. Assim, o valor de um determinado objeto e a ação em relação a ele surge do significado que a pessoa lhe atribui ${ }^{(12)}$.

As idéias fundamentais do Interacionismo Simbólico, segundo Charon $^{(114)}$, focalizam: (1) o papel da interação social; (2) o papel do pensamento; (3) o papel da definição; (4) o papel do presente e (5) o papel da atividade humana. Todos esses papéis serão definidos a seguir:

(1) O papel da interação social: ao enfocar as interações entre os indivíduos, o Interacionismo Simbólico cria uma imagem mais ativa do ser humano e rejeita sua condição passiva e determinada. A interação implica em pessoas agindo em relação a outras, percebendo, interpretando e, novamente, agindo. A ação individual é construída ao longo do tempo, o que pressupõe que poderá ser continuamente modificada. Na interação, há uma influência constante e dinâmica de um indivíduo sobre o outro, que inicia no passado e emerge na ação humana, mais do que uma mera resposta ao outro. A interação se torna central para quase tudo que se faz.

(2) O papel do pensamento: a interação não se refere simplesmente ao que está acontecendo entre as pessoas, mas também no interior da pessoa. Os seres humanos agem de acordo com a 
maneira como definem a situação na qual se encontram. Essa definição pode ser influenciada pelas pessoas com as quais interagem.

(3) O papel da definição: os seres humanos definem os objetos em sua situação e agem de acordo com essa definição. A definição é construída no decorrer do tempo e é resultado da interação social e do pensamento. Assim como o indivíduo interage com os outros e consigo mesmo, ele desenvolve suas definições e, de acordo com elas, decide agir na situação que se apresenta. A realidade externa tem menor importância que a definida pelo indivíduo. Definição é tudo que é feito, não como um resultado simples da realidade, mas de como esta realidade é definida pelo indivíduo.

(4) O papel do presente: a ação resulta, essencialmente, do que está acontecendo no presente, não do que aconteceu no passado. $O$ passado entra na ação porque o indivíduo o evoca (pensa) e o aplica à situação que está vivenciando, definindo-o na situação. $O$ que está acontecendo na situação presente fará total diferença em como o indivíduo agirá.

(5) O papel da atividade humana: o Interacionismo Simbólico descreve o ser humano como imprevisível e ativo no mundo. O ser humano é, até certo ponto, livre naquilo que faz. Todos definem o mundo em que agem e parte dessa definição é própria de cada um: escolhas conscientes são feitas que direcionem o indivíduo de acordo com tal definição; então avaliam suas ações e a dos outros e se redirecionam.

O Interacionismo Simbólico reúne conceitos fundamentais, sendo eles: símbolo, self, mente, assumir o papel do outro, ação humana e interação social e sociedade. Tais conceitos serão descritos a seguir com base em Charon ${ }^{(114)}$. 


\subsubsection{Conceito de símbolo}

Símbolo é o conceito central de toda perspectiva do Interacionismo Simbólico. Sem ele não se pode interagir com os outros. O símbolo é um objeto social utilizado pelo indivíduo para representar e comunicar algo. Será simbólico quando dotado de intenção, de significado, ou seja, o indivíduo utiliza-se do símbolo intencionalmente com o objetivo de atribuir um significado, um sentido para si e para o outro com quem interage.

Objeto social é tudo que pode se perceber no mundo, como objetos físicos, humanos, passado, futuro e o self. Tudo poderá tornar-se objeto social para o ser humano, mas os objetos não possuem significado por si só. O significado deles é resultado da interação do ser humano com eles. O ser humano define os objetos e usa-os para atingir seus objetivos, podendo modificar sua definição conforme mudam os objetivos. No entanto, nem todos os objetos sociais são símbolos, pois nem sempre representam algo.

Os símbolos, significados e valores são aprendidos pelo indivíduo na interação com outras pessoas (socialização) e são parte do conjunto da cultura de um grupo. Os símbolos são objetos sociais usados pelas pessoas para a representação e a comunicação. A socialização por meio de símbolos permite uma realidade social partilhada, o entendimento dos atos uns dos outros e torna possível a complexa e contínua vida social. A comunicação simbólica torna a sociedade possível, pois é a base para a cooperação humana.

A linguagem é um tipo especial de símbolo. As palavras, mais do que qualquer outro símbolo, podem ser produzidas intencionalmente e podem representar a realidade, por isso, são o mais importante tipo de símbolos e tornam possível todos os outros. Para identificar se um símbolo tem significado para o outro, muitas vezes é preciso que este seja complementado pela palavra. Por meio da linguagem e dos símbolos 0 indivíduo se torna ativo na natureza e não responde passivamente aos estímulos. 
As palavras formam um sistema simbólico definido na interação. São usadas para descrever aos outros o se que observa, se pensa e se imagina. As perspectivas são um grupo de símbolos que permitem ao ser humano ver a realidade. Os símbolos são guias do que se vê, do que se nota e de como as situações são interpretadas. A interação humana faz surgir objetos sociais, símbolos, linguagem e perspectiva que levam à interação e à ação. Como a interação é um processo dinâmico e continuo, sua definição pode também mudar e sua interpretação e ação serão afetadas. Os objetos sociais, símbolos, linguagem e perspectiva também são dinâmicos, eles surgem e são transformados por meio da interação.

Os símbolos são importantes para o entendimento da conduta humana. O ser humano, por causa do uso dos símbolos, não responde passivamente à realidade imposta, ao contrário, cria e recria, define e redefine sua situação social, ativamente. Por meio dos símbolos, os seres humanos identificam, relembram, categorizam, percebem, pensam, deliberam, resolvem problemas, transcendem o espaço, o tempo e a si mesmos, criam abstrações e novas ideias e direcionam a si próprios.

\subsubsection{Conceito de self}

Na perspectiva do Interacionismo Simbólico, o self é a representação de um processo social interiorizado no indivíduo: da mesma forma que o indivíduo age socialmente em relação aos outros, interage socialmente consigo mesmo. O self é, portanto, um objeto social. O indivíduo consegue olhar e ver a si mesmo como faz com qualquer outro objeto social.

O self surge na interação e, como todo objeto social, é definido e redefinido na interação. Ele surge na infância por meio da interação com os pais e outras situações significativas, mudando, constantemente, à medida que o indivíduo interage com outros em diferentes situações. 
O self apresenta duas fases: o EU e o MIM. O Eu refere-se à resposta do organismo às atitudes dos outros, é o indivíduo como sujeito e, como tal, não se sujeita a regras socialmente estabelecidas. O MIM são atitudes organizadas que o indivíduo adota, fruto da interiorização da sociedade, constitui a pessoa como objeto. O MIM é o self social, o objeto que surge da interação, cuja ação é norteada pelas definições e expectativas dos outros que cercam o indivíduo. O EU impulsiona o indivíduo e o MIM representa a incorporação do outro no indivíduo. Portanto, a ação é impulsionada pelo EU e o ato é direcionado pelo MIM.

A importância desse conceito está relacionada a todo processo de interação interna do indivíduo, em relação a si próprio, como autocomunicação e autoconceito, identidade, percepção e julgamento de si, autocontrole e autodireção. Estas ações são denominadas comunicação simbólica e tornam possíveis todas as demais.

\subsubsection{Conceito de mente}

Segundo Mead ${ }^{(115)}$, o cérebro permite ao indivíduo exercer domínio consciente sobre sua conduta. É a simbolização que permite a conduta mentalmente controlada, a partir da indicação que o indivíduo faz a si mesmo e aos outros na situação vivida. Desse modo, cérebro é diferente de mente. Para a mente, são necessários cérebros para armazenar e manipular símbolos, mas os cérebros por si sós não se constituem em mente. É a sociedade, a interação social, usando cérebros que forma a mente.

A mente é definida como ação simbólica do indivíduo em relação ao self. É o constante processo de fazer indicações para si mesmo, sobre objetos em seu ambiente, especialmente seus usos para alcançar objetivos e metas. Mente é um conceito ativo. Deve ser vista como atividade encoberta em que $O$ ator se empenha. É o que se chama pensamento. Mente não é um objeto social como o símbolo e o self, é uma ação que o indivíduo faz por meio de si. É uma comunicação ativa com o self pela 
manipulação de símbolos. Em quase todas as situações, o ator empenha-se em manifestar e encobrir a atividade mental. A atividade manifesta é causada por uma atividade encoberta e a própria ação evidente é considerada quando a ação encoberta retorna em direção ao self.

Pela atividade mental (pensar), o indivíduo faz indicações para si próprio, atribui significados, interpreta, dando sentido às coisas em relação àquela situação ou ao fato vivenciado. Dessa forma, a ação é a resposta não a objetos, mas à interpretação ativa do indivíduo a esses objetos.

Pela mente, o indivíduo fala consigo mesmo sobre como agir em determinada situação e seus atos fazem sentido para ele; aplica-se o que se sabe na situação, planeja-se o que fazer, predizendo as reações dos outros e, com base nas ações dos outros, altera-se planos e definições. Mente significa que o ator seja perfeitamente capaz de interromper uma ação, retomá-la e colocá-la fora de ação, de imediato, imaginando o que fazer antes de fazê-lo.

A atividade mental é intensificada quando as pessoas deparam-se com problemas. Consciente do problema, o ator deliberadamente irá tentar reajustar-se a situação, para poder seguir em frente. Diante dos problemas, independente da natureza, a atividade mental torna-se mais consciente, planejada e ensaiada, requerendo escolhas deliberadas.

A atividade mental acompanha toda a interação social, desde 0 entendimento das constantes demandas da interação, interpretação, definição e outras situações. A interação envolve a avaliação dos outros, a qual faz indicações a respeito deles para que se possa definir e redefinir 0 que eles estão fazendo em relação ao indivíduo e avaliar o que eles estão fazendo em relação a eles. A interação não é resposta ao estimulo, fixada e automática ou, simplesmente, evidente e física. Ela acompanha a atividade mental. 


\subsubsection{Conceito de assumir o papel do outro}

Assumir o papel do outro é uma qualidade do ser humano, sendo uma atividade mental importante, pois torna possível o desenvolvimento do self, a aquisição e uso de símbolos e a própria atividade mental. Envolve a habilidade em assumir a perspectiva do outro quando se age no mundo, vendo o mundo a partir do ponto de vista da outra pessoa. É um processo que acompanha toda a interação social, toda a comunicação simbólica e grande parte da colaboração humana. Diz muito do que se aprende e muito de como o ser humano influencia os outros.

Mesmo assumindo o papel do outro e capturando com precisão a perspectiva do outro, o ser humano continua não podendo deixar sua própria perspectiva de lado e seu entendimento será colorido, em parte, por sua própria perspectiva.

Ao assumir o papel do outro, o indivíduo busca uma explicação para a ação que observa e, em consequência disso, alinha sua ação à razão identificada. Assim, tal conceito é considerado uma condição para a comunicação e interação simbólica.

\subsubsection{Conceito de ação humana}

A ação humana refere-se à capacidade que o ser humano possui de fazer indicações para si mesmo, sendo processo simbolicamente construído e diz muito a respeito do indivíduo que a realiza. $O$ indivíduo investiga significados dos outros e define sua própria linha de ação com base na interpretação. Por meio do processo de autointeração o indivíduo manipula seu mundo e constrói sua ação.

A ação humana é um fluxo de ação continuo, desenvolvido em um processo constante em que um ato leva ao outro e, assim, nunca se encerra, exceto quando se morre. O ser humano engaja-se em uma linha de ação influenciado por decisões, as quais, por sua vez, sofrem influência da 
interação com outros e consigo mesmo. É uma continua decisão que surge de uma continua definição. A ação tem uma história que é direcional. E as direções mudam por causa das muitas decisões, definições e ações que são realizadas.

O fluxo da ação humana é separado por atos. Um ato é um seguimento dentro do fluxo de ação e torna-se um objeto social conforme seja isolado e definido de acordo com as metas do presente. As ações do indivíduo são determinadas pela definição da situação no presente. $O$ passado não causa uma ação no presente, embora possa contribuir baseado nas experiências para definir a situação e guiar a ação. A ação no presente também é influenciada pelo futuro, pois esta poderá ter consequências futuras. Desse modo, as possíveis consequências dos atos são imaginadas antes da ação.

Assim, experiências passadas, futuro, motivos e emoções entre outros, são objetos sociais usados para definir a situação, em uma ação encoberta, para guiar a ação aberta.

\subsubsection{Conceito de interação social}

Todos os conceitos básicos do Interacionismo Simbólico surgem da interação social e fazem parte desta. Quando se interage, o indivíduo se torna objeto social para o outro, usa símbolos, direciona o self, engaja-se em atividade mental (encoberta), toma decisões, muda as direções, compartilha perspectivas, define a realidade, define a situação e assume papéis. Para compreender-se a natureza da interação deve-se reconhecer a existência de todas estas fases.

A interação é constituída na ação social e significa atores levando em consideração uns aos outros, comunicando e interpretando uns aos outros. E é este processo de troca que é entendido por interação, a qual significa 
linhas de ação cruzada, cada uma influenciando a outra, ambas determinadas por decisões unilaterais.

A interação social coloca a ação humana diretamente na esfera de sua vida social. O que as pessoas fazem, revelam, ao longo do tempo, como elas tentam experimentar suas ações nas situações, alterando seus atos com base no que os outros fazem. Mudar planos, estabelecer metas, definições e direções dependem da troca estabelecida na interação social.

A interação é simbólica quando a ação de cada indivíduo tiver significado para quem a criou e para o receptor da ação. Isto significa que cada um estará interagindo simbolicamente consigo, enquanto age em relação ao outro e observa o outro. O indivíduo, de forma intencional, comunica-se quando age e os outros interpretam o que ele faz.

A interação simbólica continua é necessária para a cooperação e para a sociedade, sendo uma importante causa para o que os atores fazem ou tornam-se. Os outros não causam o que um indivíduo faz, ele interage com eles e esta interação causa tudo o que ele faz.

A interação social é central para o Interacionismo Simbólico, pois cria perspectivas, torna-se o ângulo de visão, o guia para a realidade que surge da interação com os outros. A interação cria objetos sociais e símbolos, as pessoas falam umas com as outras e apontam coisas em seu ambiente, coisas que possuam significado, simbolizando uma linha de ação. $O$ significado é visto como um produto social, formado na e pela definição das atividades das pessoas com as quais um indivíduo interage.

A interação cria e define o self, os seres humanos veem-se como objetos devido à interação deles com os outros. Aqueles interagem com outros significantes, grupos de referência, desenvolvem autocontrole e, assim, são capazes de um número de coisas em relação a seu self. Além disso, o processo de agir em direção ao self (controlar, comunicar, analisar, nomear e julgar) depende em grande parte dos tipos de ação que são direcionadas a eles na interação. Como os outros os tratam, os veem e 
agem em direção a eles é importante para o que fazem em relação aos outros.

A interação cria e influencia a mente, a ação mental é a resolução de problemas, devendo levar-se em conta o que está acontecendo no ambiente, o qual inclui especialmente as ações dos outros em direção a eles e as ações deles em direção aos outros.

$\mathrm{E}$, finalmente, a interação cria e influencia a habilidade do indivíduo de assumir papéis. Como assumem os papéis depende da interação deles e quanto melhor os assumirem melhor será sua capacidade de compreender os outros.

A interação é uma qualidade humana central que possibilita todas as outras qualidades. Quando eles interagem, definem os outros pela perspectiva, os outros são objetos sociais, os vários atos de cada pessoa são simbólicos, eles agem em direção ao self como agem em direção aos outros, engajam-se em atividade mental quando interagem e o assumir papéis é uma parte central do que fazem para compreender os outros.

\subsubsection{Conceito de sociedade}

Sociedade é um conceito central no Interacionismo Simbólico e integra todos os outros, ajudando a compreender a natureza dos seres humanos. A sociedade, na perspectiva interacionista simbólica, é concebida como qualquer tipo de organização. Cada díade, cada grupo, cada organização, cada situação interacional, cada mundo social ou, ao menos, uma sociedade em estágio inicial de desenvolvimento.

A sociedade é formada, reafirmada, alterada e mantida pela interação social. A ausência de uma continua interação, desse modo, faz que a sociedade deixe de existir. A sociedade depende de indivíduos, continuamente, interagindo uns com os outros e consigo mesmos, em uma linha de ação infinita. A interação social significa que os atores considerando 
os atos dos outros e, o que eles decidem sobre a ação, dependerá dos fatos partilhados em uma relação interdependente.

No entanto, sociedade é mais que apenas interação, pois envolve comunicação e interpretação das ações por parte dos atores. A sociedade é caracterizada, portanto, pela interação simbólica que envolve indivíduos engajando-se em ação cooperativa. A maioria das interações envolve cooperação para a resolução dos problemas, embora não seja uma regra. Entretanto, se não existir ação cooperativa para lidar com as situações, não haverá sociedade, pois esta é construída pelo esforço cooperativo no qual os atores buscam trabalhar juntos apesar das metas e interesses individuais. É o agir cooperativamente que permite que se forme uma sociedade.

A sociedade é, portanto, uma interação cooperativa que desenvolve a cultura. Cada sociedade possui uma cultura, que é a perspectiva partilhada ou de referência para a realidade. A cultura significa o consenso do grupo, a concordância, o entendimento, a linguagem e o conhecimento partilhado e as regras que orientam a ação. A cultura da sociedade torna-se o guia para a definição e ação do indivíduo. As regras internalizadas pelo indivíduo guiar a ação são definidas como o outro generalizado ${ }^{(115)}$. O outro generalizado são as leis que devem ser obedecidas, o sistema moral, a consciência do grupo que o indivíduo usa para guiar a interação social. O outro generalizado é necessário para o autocontrole e autodirecionamento, que torna a ação consistente com o que os outros estão fazendo na situação e permite que a ação entre em acordo com a direção estabelecida na interação. A cultura, desse modo, mantém a sociedade.

$E$, por fim, a sociedade é a interação cooperativa que desenvolve a estrutura social. A estrutura refere-se ao padrão de relações, como as pessoas interagem. A estrutura social é vista como a realidade que é definida, negociada e alterada na interação e usada pelo indivíduo para alcançar suas metas. A estrutura é a realidade que confronta o indivíduo e, como qualquer realidade, é interpretada pelo ator de acordo com suas próprias necessidades na situação. 


\subsection{O INTERACIONISMO SIMBÓLICO E A FAMÍLIA}

A abordagem teórica para a pesquisa de família em enfermagem, proposta por Angelo ${ }^{(5)}$ resulta de uma reformulação dedutiva, de uma articulação entre os conceitos do Interacionismo Simbólico e a definição de família, de forma a contribuir para pensar interacionalmente sobre a família e a aplicação dos conceitos na pesquisa.

A partir da visão de que família pode ser considerada pessoas em interação simbólica ${ }^{(5: 29)}$, a autora elabora os pressupostos de que família é composta por membros em interação entre si e com os elementos presentes nas experiências que vivencia; a família atribui significados às experiências que vivencia; os significados resultam das interações que a família tem com os elementos presentes na experiência.

O caminho adotado por Angelo ${ }^{(5)}$ para tal aproximação foi o de analisar o que os autores interacionistas Blumer e Mead propunham sobre sociedade destacando dois conceitos: a visão de sociedade como indivíduos em ação cooperativa e o outro generalizado.

Aplicando os conceitos de sociedade à família, Angelo ${ }^{(5)}$ apresenta uma visão de família sob a perspectiva interacionista:

- Família são indivíduos em interação simbólica;

- Família são indivíduos cooperando;

- Família é composta por indivíduos capazes de assumir o papel do outro;

- Família é composta por indivíduos com selfs;

- Família é composta por indivíduos com mentes;

- Família provê ao indivíduo uma perspectiva na figura do outro generalizado.

Considerando a interação não apenas como causa dos comportamentos humanos individuais na família, mas a base da vida familiar 
que tem seu funcionamento caracterizado por cooperação, Angelo ${ }^{(5: 44)}$, traz uma nova definição de família sob a perspectiva interacionista:

Família é um grupo de indivíduos (atores), chegando às situações com os outros significantes ou grupos de referência; com símbolos perspectivas, self, mente e habilidade para assumir papéis. Cada ator tem um passado a resgatar para ajudar a definir a situação e cada um tem uma visão de futuro. Os atores dão significado às situações usando estes instrumentos, às vezes prestando especial atenção àqueles com quem interagem na situação, outras vezes usando algo localizado fora da situação como guia.

A definição que a família atribui à situação vivenciada, segundo Angelo ${ }^{(5)}$, será aquela resultante do alinhamento de cada ação individual. Ao considerar a natureza individual dinâmica do processo de definição e também seu aspecto circunstancial, destaca o elemento cooperação na família, atuando no sentido de resolver os problemas do momento, determinados por uma definição específica.

O caminho apontado por Angelo ${ }^{(5)}$ para a compreensão do funcionamento de interno da família, na perspectiva de sua interação com a situação que vivencia, parte da ideia de tomar a família como uma unidade de atores e buscar duas dimensões, sendo a primeira a ação coletiva simbólica e a segunda a cooperação na resolução dos problemas.

A dimensão da ação coletiva simbólica fornece inicialmente informações sobre os comportamentos da família, objetivamente observados ou descritos por ela, como chorar, discutir, iniciar uma ação. A partir desse contato, tem-se informações sobre qual é a interação dos indivíduos entre si e com a situação. Aprofundando em direção à compreensão do funcionamento da família, busca-se compreender como se dá o alinhamento das ações individuais de forma a aprender as indicações que cada elemento da família faz para si mesmo, o que observa e como interpreta a situação e quais perspectivas considera. A dimensão coletiva simbólica nos diz a respeito das ações da família, mas não dos motivos que tornam as ações coletivas. 
Desse modo, a segunda dimensão é a cooperação na solução dos problemas. Esta é acessada a partir das indicações identificadas nos membros da família e, por meio dela, é possível compreender os motivos das ações no processo interacional simbólico da família. O elemento central dessa definição consiste na habilidade para assumir o papel do outro, que não é algo que acontece como um resultado acidental no indivíduo, mas é o que dá a ideia precisa sobre o controle que cada indivíduo é capaz de ter sobre sua própria resposta, na perspectiva da interação familiar ${ }^{(5)}$.

A habilidade para assumir o papel do outro, demanda que cada indivíduo compreenda a ação que o outro desenvolve, tanto as ações cobertas como as encobertas, de modo a alinhar seus atos aos dos outros. Trata-se de uma atividade mental, que significa que cada um sabe onde o outro esteja, o que está fazendo e o que está pensando ${ }^{(5)}$.

O comportamento familiar demanda não apenas a divisão de tarefas, mas a compreensão de como o comportamento pessoal se encaixa no processo como um todo. A compreensão do que está ocorrendo em termos dos próprios atos e, também, dos atos dos outros membros da família é o elemento essencial da dimensão cooperação na solução de problemas ${ }^{(5)}$.

A tentativa de compreender as interações no processo familiar em direção a solução dos problemas requer a identificação do processo mental realizado, pois a tentativa de compreender o outro demanda capacidade para ver o significado das palavras e ações dos outros ${ }^{(5)}$. 


\subsection{A TEORIA FUNDAMENTADA NOS DADOS COMO ABORDAGEM METODOLÓGICA}

Dentre as abordagens qualitativas interpretativas, elegeu-se a Teoria Fundamentada nos Dados (Grounded Theory) ${ }^{(116,117)}$ para a construção do conhecimento sobre família.

A estrutura metodológica da Teoria Fundamentada nos Dados articula-se ao Interacionismo Simbólico, visto esta perspectiva pressupor que a interação é inerentemente dinâmica e interpretativa e tratar de como as pessoas criam, representam e modificam os significados das ações. A construção da ação é o foco principal da Teoria Fundamentada nos Dados, a qual tem por finalidade descobrir processos sociais ou psicossociais fundamentais dentro de uma determinada experiência ou ambiente social estudado ${ }^{(116,118)}$.

Desse modo, A Teoria Fundamentada nos Dados é totalmente compatível como o foco de estudo e para a construção de teoria sobre família, pois pressupõe a vida social como um processo tal como ocorre em seu ambiente natural. Sob esta perspectiva, os seres humanos são vistos como agentes ativos em suas vidas e esferas de vida, o que pressupõe realidades e processos emergentes a partir das significações subjetivas, das práticas da solução de problemas e do estudo irrestrito da ação (118). Portanto, revela-se adequado à descoberta de processos de interação familiar na experiência estudada, pois sua estrutura metodológica busca descobrir explicações teóricas a partir dos significados que emergem da interação social.

A Teoria Fundamentada nos Dados foi desenvolvida pelos sociólogos Barney G. Glaser e Anselm L. Strauss, publicada pela primeira vez no livro The discovery of grounded theory (1967) que reúne as estratégias e defende o desenvolvimento de teorias ou modelos teóricos a partir da pesquisa baseada em dados, em vez da dedução de hipóteses analisáveis a partir de 
teorias existentes. Nesse método, a coleta, a análise e a teoria emergente mantém estreita relação entre si.

Assim, abordagem metodológica tem por objetivo gerar teorias ou modelos teóricos fundamentados em dados sistematicamente obtidos e analisados por meio do método comparativo constante ${ }^{(116)}$. As teorias fundamentadas são classificadas em dois grandes grupos: as teorias substantivas, quando tratam de problemas específicos, delimitados a áreas substantivas, situações e contextos particulares assim como as teorias formais, que significa gerar conceitos de alto nível de abstração e explicitar a relação entre eles para a compreensão de problemas em múltiplas áreas substantivas ${ }^{(118)}$.

A Teoria Fundamentada nos Dados é um processo sistemático de coleta e análise de dados qualitativos por meio de comparação constante destes, envolvendo várias etapas não-lineares as quais proporcionam um contínuo desenvolvimento para as etapas seguintes, com o objetivo de gerar teoria que explique e possibilite a compreensão de fenômenos sociais e culturais ${ }^{(116)}$.

Dessa forma, trata-se de um movimento do pesquisador de ir e vir aos dados, formulando perguntas e hipóteses que sirvam como suporte para o desenvolvimento de estruturas teóricas sobre os conceitos e a maneira como se relacionam ${ }^{(116)}$.

A coleta de dados realiza-se por meio de entrevista, observação, análise de documentos e publicações, ou por meio da combinação destas técnicas, as quais ocorrem concomitantes à análise pelo método comparativo constante ${ }^{(115)}$.

Os procedimentos metodológicos da Teoria Fundamentada nos Dados, por se tratar de um processo essencialmente analítico, exigem do pesquisador habilidades pessoais, tais como sensibilidade teórica e social, capacidade de utilizar dados experienciais, domínio da técnica e habilidade analítica ${ }^{(117)}$. A rigorosa obediência aos passos característicos de coleta e 
análise de dados e o desenvolvimento da sensibilidade teórica do pesquisador são exigências dessa metodologia.

O pesquisador precisa ser sensível teoricamente ${ }^{(117)}$. Com essa postura, o pesquisador será capaz de manter-se próximo aos dados e detectar acontecimentos, sem antes filtrá-los em hipóteses pré-existentes, possibilitando manter-se aberto aos incidentes e aos fenômenos ocorridos (117).

A coleta de dados inicia-se apenas com a questão básica da pesquisa, sendo a orientação da pesquisa determinada pelas observações e sensibilidade teórica do pesquisador. Assim, o pesquisador coleta, codifica e analisa seus dados e, em função dos dados disponíveis, decide que tipo de dados coletará em seguida, formando os chamados grupos amostrais de modo a desenvolver a teoria, buscando eventos ou incidentes indicativos de categorias, até que ocorra a saturação teórica. A saturação teórica é atingida quando nenhum dado novo ou relevante emerge, quando as categorias desenvolvidas alcançam densidade e permitem a compreensão do fenômeno estudado ${ }^{(116)}$.

Desse modo, o processo de coleta de dados é controlado pela teoria emergente. Esse processo é denominado amostragem teórica e tem por objetivo gerar uma teoria que integre conceitos relevantes ao fenômeno estudado ${ }^{(116)}$.

A análise dos dados é realizada por meio do método comparativo constante, que segundo Glaser e Strauss (116) é composto por quatro estágios: comparar incidentes aplicáveis para cada categoria; integrar as categorias e suas propriedades; delimitar a teoria e escrever a teoria.

No primeiro estágio, a análise dos dados tem início com a codificação aberta. A codificação inicial requer uma leitura atenta dos dados e o objetivo é que o pesquisador se mantenha aberto a todas as direções teóricas possíveis indicadas pela leitura dos dados. Assim, os dados são examinados minuciosa e exaustivamente, linha a linha, para que se possa identificar 
incidentes que conduzam a elaboração dos códigos. A codificação inicial se fixa rigorosamente aos dados, e ações são observadas em cada segmento de dados. Os códigos iniciais são provisórios e comparativos, devem ser comparados com outras codificações, dentro da mesma entrevista, grupo ou em entrevistas diferentes.

A comparação constante entre os códigos iniciais permite que estes sejam agrupados por similaridades e diferenças conceituais. Tal processo dá início às propriedades teóricas da categoria. Nesse momento da análise comparativa constante é indicado que o pesquisador escreva os chamados memorandos. Os memorandos provêm uma imediata ilustração das ideias sobre os códigos, categorias e relações entre eles e auxiliam o pesquisador na formulação de questões e hipóteses que permitam a densificação das categorias e a integração clara da teoria.

No segundo estágio, integrar as categorias e suas propriedades, a comparação constante muda de incidente a incidente, para uma comparação entre incidente e propriedades de categorias que resultaram da comparação inicial entre incidentes. Esta etapa é chamada de codificação teórica e consiste em realizar agrupamentos de categorias que se referem a um mesmo fenômeno. Com isso, as categorias são reorganizadas, fazendo-se conexões entre as categorias e subcategorias de forma a realizar agrupamentos, unindo as categorias a um fenômeno.

A delimitação da teoria, terceiro estágio da análise, ocorre em dois níveis: da teoria e da categoria. A teoria solidifica-se, primeiramente, quando as modificações ocorridas na comparação dos próximos incidentes de uma categoria e suas propriedades vão diminuindo. No segundo momento, as modificações ocorrem para esclarecer propriedades, integrando detalhes e reduzindo as categorias. A redução da teoria significa a descoberta de uniformidades subjacentes no conjunto original de categorias ou suas propriedades, permitindo a formulação da teoria com um menor grupo de conceitos de alto nível. O segundo nível de delimitação da teoria e categorias permite a compreensão do fenômeno ou categoria central, 
representando o elo entre todas as outras categorias, integrando-as e permitindo formar uma teoria.

O quarto estágio é o da redação da teoria. Após terem sido seguidas todas as etapas de análise preconizadas pelo método comparativo constante, o pesquisador possui dados codificados, uma série de memorandos e uma teoria. O conjunto de memorandos e categorias é integrado de forma a construir a teoria fundamentada nos dados.

As estratégias metodológicas da Teoria Fundamentada nos Dados utilizadas na pesquisa com família serão descritas com maiores detalhes no próximo capítulo. 
O processo de pesquisa

\section{CAPÍTULO III}




\subsection{REALIZANDO A PESQUISA COM FAMÍLIA}

O processo de pesquisa com família impõe ao pesquisador uma série de desafios conceituais e metodológicos, devido à complexidade da trajetória a ser percorrida entre a elaboração da questão da pesquisa e a construção de um conhecimento sobre família.

Entre os desafios envolvidos na pesquisa com família, destacam-se: a conceituação de família; a definição e a operacionalização da unidade de análise, a escolha dos sujeitos para a obtenção dos dados e as formas como serão inclusos na pesquisa. $E$, também, o acesso à família, assim como o recrutamento de múltiplos membros da família ${ }^{(119)}$; a escolha do ambiente para a condução da coleta de dados; a escolha de estratégias metodológicas compatíveis à complexa tarefa de capturar a experiência da família a partir de um ponto de vista interacional; bem como a habilidade para gerar e analisar dados relacionais, provenientes de respostas de múltiplos membros da família ${ }^{(113)}$.

A questão da pesquisa determina o foco e o desenho da investigação, determinando, portanto, o tipo de pesquisa que será realizada sobre família. Ao definir-se como questão de pesquisa "como a família experiencia o processo de transição do cuidado da criança com necessidades especiais de saúde do hospital para o domicílio? conduz-se a estudar a vida familiar nessa circunstância específica. Assim, o foco de investigação é a unidade familiar em interação com e em seu ambiente natural, portanto, caracterizase como uma pesquisa de família. Entende-se que a mudança do hospital para o domicílio, mais que um evento, é um processo interacional, que pode ser melhor compreendido na perspectiva da família como uma unidade em interação, devido à transformação concreta de suas condições de vida.

A diferença entre uma pesquisa de família e uma pesquisa relativa à família está na definição da unidade de análise. Uma pesquisa relativa à 
família é aquela que considera as respostas individuais de membros da família. A Pesquisa de família é compreendida como aquela segundo a qual a família é considerada a unidade de análise e, portanto, é conduzida de forma a possibilitar uma compreensão da unidade familiar, no qual o individuo não é destacado do todo, e sim o comportamento da unidade familiar como uma totalidade é considerado. $\mathrm{O}$ foco se modifica do indivíduo para suas inter-relações, as quais constituem em si categorias de análise (119).

Ao adotar-se a perspectiva sistêmica, aplicada à definição de família, é possível compreendê-la como um complexo de indivíduos e mútua interação, o que possibilita visualizar a família como uma unidade e focalizar a interação entre seus membros e destes com os sistemas mais amplos ou os suprassistemas, representados pelas instituições sociais e pessoas com as quais a família tem contato significativo, envolvendo, por exemplo, os sistemas de cuidado de saúde, os sistemas de trabalho, comunidade e a sociedade mais ampla.

O sistema familiar é, portanto, parte de um suprassistema e composto de muitos subsistemas, como o subsistema individual, subsistema conjugal, subsistema paterno e/ou materno, subsistema de irmãos, subsistema de avôs, entre outros sistemas que podem ser criados para estabelecer limites internos na unidade familiar, como sistemas de valores morais, crenças, expectativas ou papéis ${ }^{(1)}$. Desse modo a totalidade da família é muito mais do que a simples soma de seus membros ${ }^{(1)}$, sendo compreendida como um sistema estrutural e funcional, em constante interação com seu ambiente (121).

Cabe ao pesquisador destacar premissas importantes ao considerarse a família como sistema, as quais influenciam diretamente a operacionalização da unidade de análise: (a) ênfase sobre padrões de interação; (b) compreensão do comportamento sob o ponto de vista da causalidade circular; (c) subjetividade e (d) complexidade. 
Considerando a família, sob a perspectiva interacionista, esta é compreendida como um grupo social em interação entre si e com os elementos presentes nas experiências que vivencia, atribuindo significados a estas experiências resultantes de suas interações ${ }^{(5)}$. A família, desse modo, pode ser vista como um grupo autoidentificado, que partilha de uma realidade histórica e simbolicamente construída.

A fim de respeitar tanto a subjetividade assim como as particularidades das composições dos sistemas familiares, os relacionamentos significativos e as experiências de saúde e doença, uma definição de família aplicável a esta pesquisa é "família é quem seus membros definem que são" ${ }^{(1: 48)}$.

Família pode ser definida como um grupo de indivíduos unidos por fortes vínculos emocionais, com senso de pertencimento e a inclinação para participar das vidas uns dos outros ${ }^{(10)}$. Tal definição aproxima de atributos para o conceito de família, tais como a existência de compromisso e vínculo afetivo entre os membros, que abrange obrigações futuras e de família como uma unidade de cuidados ${ }^{(122)}$, que tem como principais funções a proteção, o sustento, a socialização de seus membros ${ }^{(1)}$, funções estas promotoras da vida e do bem-estar ${ }^{(122)}$. Desse modo, pode-se conceber a família como um sistema cultural de cuidado de saúde diferente e complementar ao sistema profissional de saúde ${ }^{(123)}$.

De acordo com a especificidade da pesquisa, a unidade de análise foi definida como sendo composta por, pelo menos, dois indivíduos capazes de representar a unidade familiar e contribuir para a compreensão do fenômeno estudado, bem como as interações familiares produzidas em seu cotidiano.

A força da pesquisa qualitativa de família está na capacidade para gerar dados ricos em torno da experiência subjetiva da família ${ }^{(119)}$, com o potencial para compreender, tanto a experiência dentro da família, quanto entre a família e sistemas externos, dados estes que podem aumentar a compreensão dos processos psicossociais familiares, das relações, assim como do funcionamento do sistema familiar na situação de transição do 
hospital para o domicílio e ajustamento a condição de viver com a criança com necessidades especiais de saúde em seu próprio ambiente.

\subsubsection{Considerações éticas}

O compromisso e o respeito aos aspectos éticos envolvidos no processo de pesquisa com seres humanos assumem particularidades em função do tipo de pesquisa que é desenvolvida em cada uma de suas etapas (antes, durante e após o término da coleta de dados).

Então, em respeito às diretrizes que regulamentam a pesquisa com seres humanos, contidas na resolução 196/96 do Conselho Nacional de Saúde ${ }^{(124)}$, o projeto de pesquisa foi encaminhando ao Comitê de Ética em Pesquisa do Hospital Universitário da Universidade de São Paulo (CEPHU/USP), o qual é aprovado pela Comissão Nacional de Ética em Pesquisa do Ministério da Saúde (CONEP/MS) e registrado no Sistema Nacional de Informação sobre Ética em Pesquisa envolvendo Seres Humanos (SISNEP). Assim, uma vez que o projeto foi aprovado pelo CEP-HU/USP, em novembro de 2008 (Anexo 1), a autorização para a realização da pesquisa foi concedida pelos serviços envolvidos, após processos de análise internos.

A pesquisa qualitativa com famílias requer informações profundas e detalhadas sobre as experiências de vida dos indivíduos, as quais vêm acompanhadas de fortes memórias e emoções, em especial, quando pesquisa-se situações que envolvam dor e sofrimento, em especial o caso do viver com a doença grave e limitadora do tempo de vida da criança. $O$ acesso a informações privilegiadas, que fazem parte da vida privada do indivíduo e da família, deve vir acompanhado pela responsabilidade e o compromisso, tanto de criar uma ética relacional ${ }^{(125)}$, durante o diálogo estabelecido na situação de entrevista, como de representá-la de forma autêntica e respeitosa no relatório de pesquisa ${ }^{(125-127)}$. 
A obrigação moral existe para o pesquisador assegurar que haja uma justificativa sólida para a investigação e o método de pesquisa, que se estende além da curiosidade intrusiva e que atinge mais do que contar histórias tristes ${ }^{(128)}$.

Dada a complexidade das relações interpessoais desenvolvidas entre o pesquisador e a família, no contexto da investigação qualitativa, o pesquisador deve ter como preocupação constante de manter-se sensível ao risco dos participantes, enquanto é assegurada a integridade da pesquisa. Essa preocupação quanto aos componentes éticos da relação entre o pesquisador e os pesquisados, na investigação qualitativa, deve estar evidenciada desde a concepção do estudo até a comunicação dos resultados ${ }^{(127)}$.

\subsubsection{Localização e acesso às famílias}

A definição do foco da pesquisa, voltado para a compreensão da experiência da família na transição de crianças com necessidades especiais de saúde, do hospital para o domicílio, conduz à busca por grupos familiares específicos. Os critérios estabelecidos foram que os sujeitos participantes da pesquisa seriam indivíduos representantes do sistema familiar, com vínculos afetivos e de compromisso com a criança, diretamente envolvidos no processo de transição.

No que se refere aos critérios estabelecidos em relação à condição clínica da criança, dentro do grupo de crianças com necessidades especiais de saúde, foi determinado que a criança tivesse uma condição crônica de natureza física, com demandas de cuidados contínuos e permanentes, e devesse ser dependente de tecnologia médica de suporte de vida. O tempo de diagnóstico e de hospitalização, o tempo de cuidado domiciliar assim como o estágio de desenvolvimento da doença não foram considerados como critérios para a seleção dos participantes. 
A busca pelas famílias, com base nos critérios definidos, teve início no hospital. Essa busca inicial teve como finalidade, fazer um levantamento de famílias que estavam vivendo o preparo para a transição do hospital para o domicílio e de famílias que já haviam vivenciado a transição, e, portanto, estavam cuidando da criança em seu próprio ambiente doméstico.

Após esse primeiro contato, com base no expressivo número de crianças vivendo em casa com suas famílias, tomou-se a decisão de coletar os dados com esses grupos familiares, a fim de explorar a trajetória do sistema familiar, como se deu a inserção concreta do cuidado da criança com necessidades especiais de saúde no ambiente da família, bem como a forma como sistema familiar lida com essa condição circunstancial de vida e os elementos de força ou fragilidade presentes na experiência.

A localização e o acesso às famílias se deram via serviços de saúde de atendimento domiciliar, na cidade de São Paulo, sendo um vinculado ao setor público e outro ao setor privado. Apenas uma família, por não possuir vínculo com serviços domiciliares, foi contatada mediante indicação de outros participantes da pesquisa.

O primeiro grupo, composto por sete famílias de crianças com necessidades especiais de cuidado de saúde, vinculado ao serviço público, foi contatado por conta do Programa de Assistência Domiciliária (PAD) do Hospital Universitário da Universidade de São Paulo (HU-USP).

O acesso às famílias se deu por conta do acompanhamento das visitas e dos atendimentos domiciliares realizados pela equipe multiprofissional. Na ocasião, os profissionais do programa atuaram como facilitadores do primeiro contato com a família, bem como do acesso ao domicílio da família, inserindo o pesquisador em suas atividades e apresentando-o às famílias.

Nesse contexto de visita domiciliar, era realizada a abordagem da família, primeiro com 0 fornecimento de esclarecimentos sobre 0 pesquisador e de seu papel, passando a esclarecimentos sobre a pesquisa e 
os procedimentos envolvidos e, então, era feito o convite à participação no estudo. Nessa ocasião, era combinado com os familiares presentes que seria feito um contato telefônico para verificar 0 interesse quanto à participação. Verificado o interesse da família, agendava-se o melhor dia e horário para a realização da entrevista, de acordo com o que fosse conveniente para a própria família e de modo que as pessoas escolhidas pelo grupo pudessem estar presentes. Na véspera do dia marcado para a entrevista, era feito um novo contato telefônico com o núcleo familiar para confirmação, dada a possibilidade de haver desistência por parte deles ou de intercorrências com relação à criança.

O segundo grupo, composto por três famílias de crianças com necessidades especiais de cuidado de saúde vinculado ao serviço privado, foi contatado por meio do serviço Medicina Familiar e Preventiva (MEDLAR), vinculado a Sociedade Brasileira de Medicina de Família (SOBRAMFA). Nesse, apesar de ter acompanhado algumas visitas junto com a médica pediatra, o contato com as famílias se deu de forma diferenciada, visto que, entre as famílias inicialmente visitadas, apenas uma se encaixava no perfil do estudo e esta não se mostrou acessível para a participação na pesquisa. Assim, a fim de facilitar e agilizar o contato com famílias, a médica responsável pelo atendimento domiciliar realizou, previamente, um contato telefônico com as famílias. Nesse contato, foram fornecidas informações sobre a pesquisa e solicitado a autorização da família para a informação de seus dados para contato, como endereço e telefone. Diante da autorização das famílias, os dados foram fornecidos ao pesquisador.

De posse dessas informações, procedeu-se o contato telefônico com a família, foram fornecidas explicações detalhadas sobre o motivo do contato, sobre o pesquisador e a pesquisa que estava se propondo a desenvolver, esclarecidas as dúvidas da família e feito o convite para a participação na pesquisa. Nessa ocasião, apesar de todas as famílias prontamente aceitarem, combinava-se um novo contato telefônico para confirmar o interesse, para que tivessem um tempo para conversarem entre si e decidirem sobre os detalhes de sua participação. Verificado o interesse, 
agendava-se o melhor dia e horário para a ida à residência da família e a possível realização da entrevista, visto que era o primeiro contato pessoal com a família, e poderiam existir ainda dúvidas ou receios.

A última família participante do estudo foi indicada, por uma das famílias que haviam participado do estudo. O contato com a família indicada foi mediado pela família entrevistada. Nesse caso, a própria mãe participante da pesquisa foi quem acompanhou o pesquisador até a residência da família e quem procedeu às apresentações. Do mesmo modo, feito o contato com a família, procedia-se a abordagem em relação à pesquisa, e verificado o interesse agendava-se a data e horário para a realização da entrevista.

Assim, todas as entrevistas foram realizadas nos domicílios das famílias, tanto pela dificuldade de locomoção das famílias devido à dependência da criança, e por considerar-se ser uma opção que possibilita uma melhor compreensão do fenômeno estudado, bem como a operacionalização da categoria de análise, no que se refere à captação de múltiplos membros da família e a observação das interações familiares em seu ambiente natural.

\subsubsection{Caracterização dos serviços de atendimento domiciliar}

Os serviços de atendimento domiciliar são classificados de acordo com sua forma de trabalho em, basicamente, quatro modalidades: atenção domiciliar, visita domiciliar; atendimento domiciliar e internação domiciliar ${ }^{(129,}$ 130)

A atenção domiciliar é a modalidade que, de forma ampla, envolve ações de promoção à saúde, prevenção e tratamento de doenças e reabilitação desenvolvidas em domicílio. A visita domiciliar pode ser entendida como o atendimento realizado por profissional e/ou equipe de saúde na residência do paciente, com o objetivo de avaliar as necessidades deste, de seus familiares e do ambiente onde vive, para estabelecer um plano assistencial voltado à recuperação e/ou reabilitação ${ }^{(129,130)}$. 
O atendimento domiciliar compreende as atividades assistenciais exercidas por profissionais e/ou equipe de saúde na residência do paciente, para executar procedimentos mais complexos, que exijam formação técnica para tal. Também são realizadas orientações aos responsáveis pelo cuidado no domicílio e a periodicidade do atendimento é realizada de acordo com a complexidade do cuidado requerido. Já a modalidade de internação domiciliar envolve atividades assistenciais especializadas, exercidas por profissionais e/ou equipe de saúde na residência do cliente, com oferta de recursos humanos, equipamentos, materiais e medicamentos, assemelhando-se ao cuidado oferecido em ambiente hospitalar. A permanência de profissionais de enfermagem junto ao cliente é preestabelecida, podendo ser de seis, doze ou vinte e quatro ${ }^{(129,130)}$.

O Programa de Assistência Domiciliar (PAD), desenvolvido pelo Hospital Universitário da Universidade de São Paulo (HU-USP), desde maio de 2000, está vinculado ao serviço de ambulatório, que compreende quatro áreas, a saber: clínica médica e cirúrgica, ginecologia, obstetrícia e pediatria. São objetivos deste programa a diminuição do tempo de hospitalização do paciente e otimização do leito hospitalar; prevenir reinternações, orientar o cuidador e familiares, reinserir o paciente ao ambiente familiar, melhorar a qualidade de vida do paciente e de seus familiares e proporcionar a formação de profissionais de saúde.

O serviço é desenvolvido por uma equipe multiprofissional, formada por médicos, sendo dois clínicos e um pediatra, três enfermeiras, fisioterapeuta, odontólogo, terapeuta ocupacional, psicólogo, farmacêutico, assistente social, fonoaudióloga. E também conta com apoio do grupo de voluntários do Hospital Universitário.

Os critérios de inclusão ou de elegibilidade do paciente compreendem: indicação e pedido da equipe que o assiste, devendo reunir condições clínicas para o atendimento domiciliar (incapacidade funcional determinada por meio da aplicação da Escala Funcional da Cruz Vermelha Espanhola), possuir um cuidador domiciliar eleito pela família e ser residente 
na área de abrangência do HU-USP, que compreende a região da subprefeitura do Butantã, na zona oeste da cidade de São Paulo.

A avaliação inicial é realizada com o paciente ainda internado pelo assistente social e pelo enfermeiro. Após a alta, o atendimento é executado por agendamento, segundo o estado de dependência dos pacientes, sendo que os enfermeiros realizam, em média, oito atendimentos por dia, sendo quatro por turno. $O$ cuidador familiar pode também solicitar orientações ou comunicar complicações com o paciente, mediante contato telefônico com os profissionais e os atendimentos agendados podem ser reorganizados em função da necessidade do paciente ou do cuidador.

Cada procedimento de atendimento ou visita domiciliar realizada é anotada em um formulário próprio e único para todos os profissionais, em duas vias, sendo que uma delas permanece na residência do paciente e a outra passa a integrar o prontuário do paciente, arquivado no serviço.

Atualmente, o PAD acompanha cerca de 100 pacientes domiciliados, incluindo adultos, idosos, que representam cerca de $70 \%$ dos pacientes, e crianças, todos portadores de doenças crônicas graves, como câncer, neuropatias e doenças pulmonares crônicas. O Programa também atendente pacientes em cuidados paliativos.

Dentro do PAD, devido ao aumento da demanda de crianças em estado considerado crônico, foi criado o Programa de Atendimento Domiciliário Pediátrico (PED), cujo objetivo é agilizar a desospitalização, diminuição das reinternações e inserção destes no convívio familiar. Também foi instituído o Programa de Oxigenoterapia Domiciliar (POD), uma vez que havia um grande número de crianças necessitando de suporte ventilatório sem que, no entanto, precisassem ficar internadas.

O PAD desenvolve como atividades: a visita e a assistência em domicílio; o fornecimento de materiais de consumo, como sondas de aspiração, materiais para curativo; o empréstimo de materiais e equipamentos de uso prolongado, por exemplo, cadeira de rodas, cama 
hospitalar, aspirador, a fim de facilitar o atendimento do paciente; serviço de coleta domiciliar laboratorial e imunização; supervisão dos cuidados prestados e realização de reorientações quando necessário, bem como reuniões com cuidadores e com as famílias; realização de atividades lúdicas, passeios e oficinas de terapia ocupacional com pacientes e suas famílias. $O$ PAD também presta apoio à família após o óbito do paciente, por meio do Programa de Atendimento à Família Enlutada (PROAFE).

No que se refere aos pacientes pediátricos, O PAD acompanha entre 17 e 20 crianças portadoras, em sua maioria, de neuropatias crônicas, dependentes de tecnologia de suporte ventilatório e nutricional e acamadas. A média de idade é de 5,8 anos e o principal cuidador eleito é a mãe, sendo eventualmente substituída por outro membro da família, identificado como cuidador secundário.

Os cuidadores eleitos recebem um treinamento em relação aos cuidados que serão prestados no domićlio, realizado ainda no período em que o paciente se encontra internado, ministrado pelo enfermeiro responsável pela clínica ou unidade de internação. Após a alta e quando já estão em sua residência, os profissionais do PAD/PED supervisionam os cuidados prestados, realizando reorientações quando necessárias.

A firma Medicina Familiar e Preventiva (MEDLAR) é uma empresa privada, cujos serviços são desenvolvidos por profissionais vinculados à Sociedade Brasileira de Medicina de Família (SOBRAMFA), lugar no qual desenvolvem o trabalho acadêmico de formação de médicos de família. A entidade presta serviços para outras empresas, entre elas hospitais e empresas de cuidado domiciliar. A área de abrangência envolve a Grande São Paulo e a Região do ABC Paulista, parte da região Metropolitana de São Paulo, a qual abrange os municípios São André, São Bernardo, São Caetano do Sul, Diadema, Mauá, Ribeirão Pires, e Rio Grande da Serra.

Os serviços prestados para as empresas compreendem a abordagem da medicina de família para o gerenciamento de pacientes no domicílio, cuidado de pacientes crônicos, cuidados paliativos e cuidado de crianças 
com doença crônica; atendimento hospitalar; atendimento ambulatorial e atendimento em casas de repouso ou de retaguarda.

No que se refere ao gerenciamento dos pacientes pediátricos, a MEDLAR centraliza $o$ atendimento domiciliar da criança e promove 0 cuidado da família, evitando internações hospitalares em enfermarias ou Unidade de Terapia Intensiva e buscando adequar os cuidados necessários no próprio domicílio.

O atendimento é realizado por uma equipe contendo: pediatra com enfoque na dinâmica familiar, enfermeira, fisioterapeuta, fonoaudióloga e nutricionista. As visitas domiciliares são programadas conforme a complexidade de cada criança, podendo ser quinzenais, mensais ou bimestrais. São acompanhadas entre sete e doze crianças, portadoras, em sua maioria, de neuropatias e pneumopatias crônicas e de malformações congênitas, a média de idade é de 4,3 anos. No que tange aos cuidadores, parte das crianças é cuidada por profissionais de empresas de Home Care em tempo integral ou parcial e parte é cuidada pelos pais ou avôs.

Cabe destacar que as famílias contatadas para a participação no estudo, tanto vinculadas ao setor público como privado, dispunham das modalidades assistenciais de visita domiciliar e de atendimento domiciliar, ou seja, as famílias participantes do estudo não dispunham em seu domicílio de profissionais atuando de forma permanente ou contínua. Desse modo, as crianças com necessidades especiais de saúde eram cuidadas de forma constante por seus pais, predominantemente pela mãe, e raramente por outros membros da família extensiva como avós.

\subsubsection{O ambiente doméstico como contexto da pesquisa}

A pesquisa foi realizada no ambiente doméstico das famílias. No que se refere à região geográfica dos domicílios, seis estavam localizados na Zona Oeste da cidade de São Paulo, em comunidades pertencentes à região 
do Butantã; um estava localizado no município de Osasco, limite de divisa com a Zona Oeste de São Paulo; outros dois estavam localizados em comunidades da Zona Sul de São Paulo; outros dois no município de Diadema, região metropolitana de São Paulo/SP. Quanto ao contexto, os domicílios tinham em comum: estarem situados em comunidades de baixa renda, inseridas em meio a bairros de classe média e classe média alta.

A realização da pesquisa no ambiente doméstico apresenta vantagens concretas: maior oportunidade dos membros da família de diferentes idades estarem presentes e de encontrar indivíduos com os quais a família mantém relacionamentos significativos; também é possível o conhecimento imediato do ambiente físico e ter acesso a experiência social da família, o que, por sua vez, possibilita a compreensão da situação familiar. No entanto, também apresenta desvantagens no que se refere ao custo envolvido no deslocamento e maior possibilidade de interrupções das entrevistas, exigindo maior habilidade e flexibilidade do pesquisador ${ }^{(1)}$.

A realização da pesquisa no ambiente doméstico foi um aspecto desafiador e, ao mesmo tempo, trouxe inúmeras contribuições para a compreensão do fenômeno estudado.

Entre as dificuldades encontradas no processo de conduzir a pesquisa nas casas das famílias, pode-se destacar o deslocamento, o acesso à comunidade e ao domicílio, visto que, apesar de ter uma oportunidade prévia de contato com o ambiente familiar junto da equipe multiprofissional, a ida até o domicílio para fins de realização da pesquisa foi desenvolvida sem um suporte administrativo ou de pessoal. Esse é um aspecto que demanda tempo, investimento pessoal e, por vezes, pode gerar algum nível de tensão no pesquisador. Algumas estratégias que ajudaram a lidar com essas dificuldades foram: o estabelecimento do trajeto e reconhecimento prévio da região geográfica onde o domicílio estava inserido, para identificação das facilidades ou dificuldades de acesso, bem como a determinação do tempo do percurso até as residências localizadas 
em regiões mais afastadas e, no que diz respeito à entrada na comunidade, foi útil as recomendações da equipe de atendimento domiciliar.

As informações fornecidas pela equipe de profissionais responsáveis pelas visitas domiciliares no que se refere ao contexto, foram de fundamental importância, tanto para a superação das dificuldades, como para a análise dos riscos envolvidos. Assim, diante de ausência de suporte operacional, de pessoal e de transporte para o pesquisador, isto acabou sendo um aspecto a ser considerado na abordagem das famílias.

No que se refere à condução da entrevista no domicílio, a dificuldade foi lidar com as interrupções, especialmente quando a unidade familiar continha outras crianças muito pequenas ávidas por atenção e quando a entrada e saída de vizinhos, amigos e parentes ao domicílio se dava de forma constante. Dada a rotina de cuidados da criança com necessidades especiais de saúde, a entrevista, algumas vezes transcorreu paralela a determinado procedimento executado por um dos pais e em outras circunstâncias precisou ser interrompida e retomada após o término dos cuidados. O que determinou um maior tempo de permanência no domicílio da família, entrevistas que estavam programadas para durar entre 60 e 90 minutos, acabaram se estendendo por, até, quatro horas.

Essas situações são alguns exemplos das dificuldades encontradas, as quais foram inclusas como parte das entrevistas subsequentes. Tais aspectos foram de fundamental ajuda na compreensão da dinâmica interna da família, da forma como os membros da família se relacionam entre si e com seu entorno social no cotidiano e, mesmo, o testemunhar as intensas demandas de cuidado da criança impostas à unidade familiar e da transformação do espaço da família pela tecnologia médica.

São inúmeros os aspectos que poderiam ser comentados sobre essa experiência riquíssima que foi conduzir a pesquisa no domicílio, no entanto, destacar-se o aspecto relacional no que se refere à confiança da família para com o pesquisador, à forma calorosa como o recebe e ao envolvimento comprometido com a pesquisa. Estes aspectos são estímulos genuínos, que 
contribuíram para a segurança na condução da pesquisa e o conforto ao estar dentro da casa da família, testemunhando de sua vida privada.

A habilidade, a flexibilidade e capacidade de concentração a fim de capturar tudo que estava sendo ouvido e observado, percebido e sentido foram aspectos desafiadores, mas, sobretudo, de extremo aprendizado. O conhecimento imediato da condição de vida familiar e do cenário do cuidado, foi fundamental para a compreensão do fenômeno estudado, acredita-se que o mesmo não poderia ter sido acessado sob essa forma se não houvesse a entrada nas casas e nas vidas das famílias.

Nota-se, que pesquisas realizadas no ambiente doméstico, considerando as ações e interações familiares que caracterizam o modo como cada família vive em seu ambiente natural, provém ideias valiosas sobre as necessidades, as forças e os recursos da família.

\subsubsection{Coleta de dados}

A qualidade e a credibilidade de uma pesquisa têm início com os dados. A lógica da teoria fundamentada orienta os métodos de coleta de dados, bem como a elaboração teórica. Pesquisadores geram teorias de fortes fundamentações a partir de dados relevantes. Os dados relevantes são detalhados, focados e completos, sendo, por sua vez, reveladores das opiniões, dos sentimentos, das intenções e das ações dos participantes, e também do contexto e da estrutura de suas vidas ${ }^{(118)}$.

$\mathrm{Na}$ Teoria Fundamentada, "tudo são dados" (131). Tudo que é descoberto no ambiente de pesquisa ou sobre o tema de pesquisa pode servir como dado. No entanto, o pesquisador constrói os dados e isso exige habilidade de discernimento de dados úteis, assim como da eficácia para registrá-los. Tal habilidade é denominada de "sensibilidade teórica" (117).

O primeiro passo para adquirir sensibilidade teórica é entrar no campo no qual se procede a coleta de dados, com o mínimo possível de ideias 
predeterminadas, especialmente, deixar de lado a lógica dedutiva ou hipóteses a princípio estabelecidas. Com essa postura o pesquisador é capaz de manter-se sensível aos dados e detectar acontecimentos, sem antes filtrá-los em hipóteses preexistentes, possibilitando, desse modo, manter-se aberto a incidentes e fenômenos que emergem da vida e do contexto estudado ${ }^{(117)}$.

Assim, a Teoria Fundamentada pode ser construída com diversos tipos de dados, tais como: dados de notas de campo, de observação participante, de entrevistas, de relatórios técnicos, análise de documentos entre outros ${ }^{(116)}$. Tudo irá depender do assunto e da acessibilidade do fenômeno, na esfera da vida dos participantes ${ }^{(118)}$.

Neste estudo, as estratégias combinadas de observação participante e de entrevista qualitativa em profundidade constituíram-se os melhores meios de acessar a experiência de vida familiar, na transição para o cuidado domiciliar da criança com necessidades especiais de saúde.

A coleta de dados ocorreu entre os meses de fevereiro e novembro de 2009. Seguindo os métodos da Teoria Fundamentada nos Dados, a estratégia inicial foi o acompanhamento das visitas domiciliares realizadas pelas equipes de saúde como meio de aproximação com as famílias e seus contextos de vida, bem como a utilização da observação participante como forma de apreender informações relevantes à orientação da coleta de dados e a configuração dos grupos amostrais.

A observação é uma estratégia que permite a captação de uma variedade de situações ou fenômenos que não são obtidos por meio de perguntas, uma vez que permite uma aproximação com o que há de mais imponderável e evasivo na realidade vivida pelos sujeitos ${ }^{(132)}$. $\mathrm{Na}$ observação participante, o pesquisador imerge no contexto escolhido para a realização da pesquisa por um determinado período de tempo para obter uma perspectiva interna do cenário ou da cultura do grupo ${ }^{(133)}$. 
Essa estratégia, inicialmente possibilitou o contato com a família em seu próprio ambiente e à medida que foi desenvolvida possibilitou a observação das interações familiares internamente, com seu meio social e com os profissionais de saúde e, conforme se estabelecia uma relação com a família, eram elaboradas questões sobre os aspectos observados na vida cotidiana dela e também introduzidas nos diálogos estabelecidos durante as visitas.

Essa estratégia aproximativa foi essencial para o estabelecimento de confiança e afinidade ${ }^{(118)}$ como forma de se obter o acesso para a realização das entrevistas e para as observações subsequentes.

Desse modo, as observações participantes ocorreram tanto antes, quanto durante, como depois da realização da entrevista de pesquisa. As visitas permitiram continuidade da observação da vida familiar, dos comportamentos, da dinâmica interna, as mudanças e as preocupações vivenciadas, bem como introduzir as crianças que compõe a unidade familiar em diálogos informais e elucidar aspectos das próprias entrevistas. Esses dados foram registrados como notas de observação, conforme exemplificado abaixo.

Eu chego à residência da família para a realização da entrevista, por volta de 14 horas. Este é o terceiro encontro com a família. Fui recebida pelo avô paterno. Ele estava reformando o tanque de lavar roupas e colocando um piso na entrada da casa. A mãe está no quarto e ao ser avisada de minha chegada diz "pode entrar estou terminado de dar o banho na S". Uma das crianças está na escola, uma está em casa e outros dois não estão. Percebo que a criança está chorando, aproximo-me dela e digo "oi S. (menina de 10 anos) o que foi?" e ela responde "minha mãe brigou comigo, porque não eu quis ajudar ela" continuo conversando com S. e pergunto o que sua mãe pediu e você não quis fazer? E ela responde "pegar as coisas para a S. (irmã doente) ela (mãe) só fica me chamando toda hora", pergunto "o que você estava fazendo, quando ela te chamou?, e ela responde "brincando ali na rua". Abraço S. e tento consolá-la e pergunto "por quê você não foi a escola hoje?", e ela responde: "não teve aula", digo que vou subir para conversar com a mãe e pergunto se quer ir comigo. Ela balança a cabeça negativamente. Eu subo até o quarto do casal e da criança doente. A mãe estava vestindo a criança. Procedemos aos cumprimentos e a mãe apresenta-me outras pessoas que estavam presentes, um o padrinho da criança dependente de tecnologia, que havia ido visitá-la e duas vizinhas, uma delas, uma menina adolescente, estava ajudando nos cuidados. O espaço é pequeno para tantas pessoas. Eu fico aguardando o término do 
procedimento, e conversando informalmente com os presentes na cena, nesse tempo o padrinho e uma das vizinhas vão embora. $O$ procedimento termina por volta de 15 horas. Uma das vizinhas (menina adolescente) permanece cuidando da criança, que agora está no berço. Estávamos nos preparando para iniciarmos a entrevista, quando uma das crianças (menino de 6 anos) chega correndo da escola e sobe até o quarto e entrega para a mãe um cartão de dia das mães que havia feito na escola. A mãe abraça-o, beija-o, agradece-o e o elogia. O menino vem abraçar-me e logo vai trocar de roupa para brincar. A mãe prefere que a entrevista seja realizada ali no quarto mesmo. Então nos acomodamos sentadas na cama do casal. Logo as duas crianças, a menina de 10 anos e o menino de 6 anos sobem, e sentam no canto da cama para assistir televisão. Entrego a eles um conjunto de desenho e pintura que havia trazido para Ihes dar. Ficam contentes e pegam com rapidez tudo. Ficam desenhando ao nosso lado. A menina faz um desenho de uma menina solitária e um parque e o menino faz uns rabiscos coloridos, e depois cobre tudo de preto. Outros dois filhos de 12 e de 20 anos subiram algumas vezes para cumprimentar-me e em outras para fazer perguntas à mãe sobre coisas triviais como "onde esta o telefone do W? (amigo)" ou "você conseguiu comprar a meia?" (filho 20 anos). (Nota de Observação, Maio, 2009).

Assim, foi possível estar em contato com as famílias além do momento da entrevista, o que foi de grande enriquecimento tanto para os dados como, para o pesquisador. O número de contatos com cada grupo familiar variou de dois a seis encontros. Esse não foi um critério definido no âmbito da pesquisa. A estratégia para a condução da observação participante foi a inserção na dinâmica de trabalho da equipe e os encontros com as famílias foram se configurando em função das demandas de assistência domiciliar.

Conforme foi se dando o contato com as famílias e de acordo com os critérios estabelecidos, estas eram abordadas para a participação na entrevista da pesquisa. A oficialização da participação dos familiares na pesquisa se deu por meio do "Termo de Consentimento Livre e Esclarecido" (Anexo 2).

A entrevista é considera um método vantajoso para coleta de dados em pesquisas qualitativas, nesse âmbito pode ser compreendida como uma conversa orientada ${ }^{(134)}$. A entrevista em profundidade permite o exame detalhado de determinado tópico ou experiência, representando um método 
útil para a investigação interpretativa. A estrutura de uma entrevista qualitativa pode variar de uma exploração vagamente orientada dos tópicos a questões focais semiestruturadas ${ }^{(118)}$.

A flexibilidade da pesquisa qualitativa permite ao pesquisador seguir as indicações que vão surgindo, enquanto se coleta os dados. Os métodos da Teoria Fundamentada nos Dados ampliam essa flexibilidade, oferecendo diretrizes e instrumentos apurados para gerar, extrair e produzir o sentido dos dados que, se forem bem utilizados, aceleram a obtenção de um foco claro do que ocorre nos dados, sem sacrificar o detalhe das ações desempenhadas ${ }^{(118)}$.

Desse modo, a entrevista com a família teve início com informações sobre a unidade familiar, sobre a situação de doença vivenciada e com a construção do genograma e do ecomapa ${ }^{1}$ da família. Estes dados foram registrados no instrumento denominado ficha da família (Anexo 3).

A estrutura da entrevista a princípio foi composta por questões amplas e abertas, como forma de nortear o início da conversa com a família. Assim, o dialogo teve início com a questão "gostaria de ouvir sobre como foi para vocês trazer o (nome da criança) para casa?".

À medida que a narrativa de cada indivíduo era construída, de forma concomitante ou complementar, de modo a prover uma perspectiva da família, eram introduzidas questões específicas sobre o que era contado, como forma de aprofundar a compreensão ou elucidar novos aspectos relativos ao processo estudado, introduzindo questões circulares ${ }^{(1)}$ do tipo "o que vocês pensaram quando surgiu a oportunidade de trazer o filho de vocês para casa?", "como foi tomada essa decisão?", "o que foi mais difícil nesse tempo?" Também foram exploradas as estratégias utilizadas pelo grupo familiar para lidar com as dificuldades e a percepção sobre o apoio na

\footnotetext{
${ }^{1}$ O genograma e o ecomapa são instrumentos utilizados para a avaliação estrutural da família. O genograma é uma árvore genealógica familiar que representa a estrutura familiar interna. O ecomapa representa os relacionamentos dos membros da família com os sistemas mais amplos (comunidade, sociedade), representando uma visão geral da situação da família, demonstrando o fluxo ou a falta de recurso e as privações familiares $\left({ }^{(1)}: 84\right.$ e 91).
} 
transição com a criança para o domicílio, mediante questões assim formuladas: "como vocês tem lidado com as dificuldades encontradas?", "vocês tiveram que tomar outras decisões difíceis?", "como foi tomar essas decisões?", "o que vocês fizeram?Por quê?", "O que ajudou ou poderia ter ajudado"?

Questões específicas direcionadas a apreender as transformações na vida familiar também foram introduzidas de forma intermediária, como exemplo: "o que vocês consideram que mudou na vida da família?"; "como era a vida da família antes e como é hoje?"; "O que vocês faziam antes e agora não fazem mais?" e "Vocês sentem falta de alguma coisa, o que vocês sentem mais falta?".

A fim de obter-se um enriquecimento dos dados sobre a vida familiar, a metáfora foi uma estratégia considerada útil, com o uso de questões como: "como você vê sua própria vida e a vida em família hoje"? e "quando você pensa em sua vida que imagem the vem em mente?" essas questões visam acessar o domínio cognitivo do funcionamento familiar, ajudaram na obtenção de dados sobre a vida familiar, na perspectiva individual e coletiva e foram reveladoras de conceitos relacionados com a autoimagem, autodefinição, autoestima e identidade. Questões focalizadas no sofrimento também foram utilizadas a fim de obter-se uma compreensão da dimensão deste na vida familiar.

Questões sobre a história de vida familiar foram introduzidas durante a construção do genograma familiar e avançaram, no decorrer da entrevista, de acordo com a particularidade de cada grupo familiar, à medida que determinados comportamentos eram evidenciados nas narrativas. Esse movimento de buscar a história de um determinado comportamento permitiu elucidação de valores e crenças, assim como de padrões de relacionamento familiar. Alguns exemplos de questões desse tipo, inclusas nas entrevistas são: "Você esta me contanto que você e seu marido têm muitos conflitos e que têm visões diferentes. Sempre foi assim? Quando vocês começaram a 
ter visões diferentes? Você acha que isso tem a ver com a situação de doença? Por quê?”.

Além do passado, aspectos relacionados ao futuro também foram explorados, como planos, medos e dúvidas. Outras questões introduzidas para compreender os processos familiares utilizados de forma obter adaptação à condição de vida, também permitiram a geração de dados relacionais. Descreve-se abaixo uma forma de obter dados relacionais, ir finalizando a entrevista e, ao mesmo tempo, demonstrar respeito pelos sujeitos participantes do estudo.

[...] "Durante a nossa conversa vocês me transmitiram muita tranquilidade, serenidade e que vocês têm muita afinidade um com o outro. Eu fiz estas perguntas para aprender com vocês esse jeito tão bonito que vocês encontraram para lidar com uma situação que, sabemos, que não é fácil, é uma situação que exige, como vocês falaram um esforço constante e vocês são muito esforçados, vocês têm uma força muito grande em lidar com as dificuldades, com aquilo deixa triste e com o que sobrecarrega. $\mathrm{E}$ vocês me contam que hoje estão adaptados e que são uma família firme e feliz. Gostaria de aprender um pouco mais sobre o que vocês foram fazendo para se adaptar, e como vocês vivem o dia a dia?" [...] (Trecho de uma entrevista conduzida com o casal, maio de 2009).

$\mathrm{Na}$ pesquisa qualitativa, o respeito é um aspecto importante, destacado no processo de coleta de dados, por se tratar de métodos interpretativos que se destinam à entrada na esfera da vida privada dos participantes. $O$ respeito aos sujeitos de pesquisa permeia a forma como os dados são coletados e seu conteúdo é elaborado ${ }^{(12)}$. O respeito aos participantes é demonstrado quando são realizados esforços conjuntos na tentativa de entender a vida dos participantes a partir de suas próprias perspectivas. À medida que se tenta ver o mundo dos participantes por meio de seus próprios olhos, é-lhes oferecido todo o respeito e a compreensão com toda a habilidade possível para interpretar suas opiniões ${ }^{(118)}$.

Cabe destacar que as entrevistas tiveram a duração de 70 a 120 minutos, foram gravadas em áudio e, a medida que cada entrevista era realizada, procedia-se à transcrição na íntegra e à análise textual delas. $\mathrm{A}$ 
análise textual ${ }^{(118)}$ é um método preconizado na Teoria Fundamentada nos Dados, que ajuda o pesquisador a definir o foco de investigação. Dessa forma, as questões da entrevista são ajustadas para a compreensão em profundidade da lógica que é construída nos dados.

Participaram do estudo 11 famílias vivendo com crianças com necessidades especiais de cuidado de saúde. Os informantes da pesquisa, ou seja, aqueles que participaram da entrevista foram onze mães, sete pais, um tio, duas avós, totalizando 21 membros entrevistados. Em relação à forma de participação dos pais, seis entrevistas foram conduzidas com o casal e uma foi conduzida com ambos os pais separadamente, por dificuldade de o pai estar presente no dia agendado para a entrevista, e posterior oportunidade para sua participação.

Com relação à participação dos pais, em quatro famílias não foi possível o contato com o pai da criança, em duas delas devido à separação conjugal e desse modo não serem acessados pela mãe para a participação na pesquisa e, nas outras duas famílias, foi devido à dificuldade de conciliar um horário para a realização da entrevista, devido à jornada de trabalho que atingia os finais de semana. Em sete famílias foi possível o contato com todos os integrantes do núcleo familiar.

Em relação à participação das crianças com necessidades especiais de saúde, estas não foram inclusas nas entrevistas devido à própria condição delas, pois diante de suas limitadas formas de interação não se permitiu explorar suas próprias perspectivas.

Quanto à participação das demais crianças, irmãos saudáveis, que compunham a unidade familiar, também tiveram uma participação restrita nas entrevistas. Como a decisão de quem iria participar da entrevista é da família, a inclusão dos irmãos foi considerada pela família como dispensável e a decisão da família foi respeitada.

Os dados obtidos com as crianças, e demais membros da família que não participaram da entrevista foram registrados nas notas de observação e 
ajudaram a compreender aspectos da entrevista e os padrões interacionais da família.

Além dos indivíduos que compõem o núcleo familiar, foi possível estabelecer contato com outros membros significativos da família extensiva, como avós, tios e padrinhos, assim como com vizinhos e amigos íntimos presentes de forma constante na vida familiar. Os dados provenientes desses encontros integram o conteúdo das notas de observação e permitiram a elucidação de aspectos relacionados à interação do sistema familiar com seu meio social.

O número de famílias participantes e os grupos amostrais foram se configurando em função dos critérios de amostragem teórica ${ }^{(116)}$ da Teoria Fundamentada nos Dados. A análise minuciosa dos dados, enquanto são coletados, permite ao pesquisador elaborar hipóteses e decidir quais dados deverá coletar e onde encontrá-los de modo a densificar as categorias analíticas emergentes e desenvolver a teoria.

Desse modo, o primeiro grupo amostral foi composto por sete famílias vinculadas a um serviço público de assistência domiciliar que estavam cuidando da criança com necessidades especiais de saúde em casa. $\mathrm{O}$ primeiro grupo permitiu a aproximação com a experiência estudada e a construção das primeiras categorias teóricas. Entre as diversas reflexões que o conhecimento emergente suscitou, foi considerada a questão sobre "como o serviço de saúde poderia influenciar a experiência de transição da família para o cuidado domiciliar da criança?".

Tal hipótese conduziu à busca de um segundo grupo amostral composto por três famílias vinculadas a um serviço privado de assistência domiciliar e um terceiro composto por uma família sem vínculo com serviços de cuidado domiciliar.

A decisão de parar de coletar os dados deu-se devido ao alcance de uma compreensão adequada dos conceitos que integram a experiência de transição da família, contemplando elementos indicativos de processo que 
refletem a ênfase interacionista simbólica, tais como perspectivas, definições, ações e consequências.

\subsubsection{Caracterização das famílias participantes}

A descrição das características das famílias participantes foi elaborada com base nos dados registrados na ficha da família e informações registradas em notas de observação.

\section{Família 1}

Família procedente da Zona Oeste da cidade de São Paulo, residente em uma comunidade de baixa renda inserida em meio a um bairro de classe média alta.

A família é composta pelo pai F., 39 anos, saudável, ensino médio, ex-metalúrgico, atualmente desempregado, desenvolvendo atividades informais de trabalho como pintor ou porteiro em condomínios residenciais; a mãe, N., 37 anos, saudável, ensino fundamental incompleto (5ำ ano), exdiarista (deixou o emprego para cuidar da filha doente), atualmente do lar; casados, consensualmente, há 20 anos. O casal possui dois filhos, A. um adolescente de 14 anos, estudante da $8^{\circ}$ ano do ensino fundamental, frequenta escola de futebol, faz acompanhamento psicológico desde março de 2007, devido ao impacto do diagnóstico da doença da irmã e alterações comportamentais decorrentes; e uma menina ㄴ.. de 2 anos e 7 meses de idade, portadora de Síndrome de Werdnig-Hoffman, diagnosticada aos 6 meses de idade. Entre 2 meses e 1 ano de idade a criança passou por várias hospitalizações recorrentes em Unidades de Terapia Intensiva Pediátrica. A última hospitalização, anterior a transição para o domicílio, teve a duração de cinco meses, ocorrendo entre 1 ano até 1 ano e cinco meses de idade. Nesse período, a criança tornou-se dependente de tecnologia de suporte de vida. Atualmente a criança, é acamada, possui traqueostomia, 
gastrostomia e é dependente de ventilação mecânica. É cuidada pelos pais em casa há 1ano e 3 meses e dispõe toda a infra-estrutura física, equipamentos e materiais necessários. A família possui suporte público de atendimento domiciliar.

A renda familiar mensal fixa corresponde a um salário mínimo, renda proveniente do beneficio social. No entanto pode sofrer variações em função das atividades informais desenvolvidas pelo pai.

A família é migrante da região nordeste do país e residem em São Paulo há 20 anos. Da família de origem de F. ficaram no nordeste o pai, com o qual perdeu o contato há muitos anos, e dois irmãos que migraram para outras regiões do país. Da família de N., todos os membros da família de origem migraram juntos para São Paulo e se alocaram em bairros periféricos da região metropolitana.

A casa em que a família vive está localizada em uma rua ampla, limite entre a comunidade e o bairro e adequada às necessidades da família. $A$ casa foi reformada pelo próprio pai, para prover uma estrutura física adequada para o cuidado da criança, como instalações de sistema de oxigênio e gerador de energia elétrica entre outros equipamentos médicos de modo a priorizar o conforto e a segurança da criança. $\mathrm{O}$ quarto do casal foi ampliado (passou a ocupar o espaço que era do quarto do filho adolescente) e é dividido com a criança e com seus aparatos tecnológicos. Tudo foi adaptado às necessidades da criança e de forma a facilitar o cuidado realizado pelos pais, como cama adaptada, bancada para equipamentos, banheira de fibra de vidro, implantada ao lado da cama, lavabo, cadeira de transporte, entre outros. Desse modo, o quarto do filho adolescente também precisou ser remanejado, sendo transferido para outro extremo da casa.

$\mathrm{Na}$ ocasião da entrevista estavam presentes todos os integrantes do núcleo familiar e a avó materna. No entanto, participaram da entrevista o casal e a avó, o filho adolescente sentiu-se envergonhado em participar e ficou por vezes observando à distância. Além do encontro para a realização 
da entrevista, foram realizados outros contatos durante o acompanhamento das visitas da equipe de assistência domiciliar. Ao todo foram quatro contatos com a família, dois antes e um após a entrevista.

\section{Família 2}

Família procedente do município de Osasco, região da Grande São Paulo, residente em um bairro de baixa renda, inserido na divisa com a zona Oeste da cidade de São Paulo.

Composta pela mãe, L., 22 anos, ensino médio, ex-caixa de padaria (deixou o trabalho na ocasião da doença da filha), atualmente do lar; em tratamento de hemorragia uterina, decorrente de complicações do parto; pai, E. 29 anos, saudável, ensino fundamental incompleto ( $7^{\circ}$ ano), Maitre; atualmente vivem uma separação conjugal, foram casados consensualmente por 2 anos e 5 meses e estão separados há 4 meses. Possuem dois filhos, Y., um menino de 2 anos, saudável, e $\underline{\mathbf{M}}$. uma menina de $1 \mathrm{a} 1 \mathrm{~m}$, portadora de Pneumopatia Crônica/Broncodisplasia, secundária a complicações decorrentes da prematuridade. Hospitalizada desde o nascimento até 11 meses de idade, tornando-se, nesse período, dependente de tecnologia. Atualmente é acamada, possui traqueostomia, gastrostomia e é dependente de oxigenoterapia contínua. Após 11 meses de hospitalização, ocorreu a transição para o cuidado domiciliar. A criança é cuidada em casa pela família há dois meses, com suporte de serviço público de atendimento domiciliar.

A separação conjugal ocorreu durante a hospitalização da criança e, após a alta da criança, a mãe mudou-se para a casa de seus pais, onde recebeu um quarto amplo para acomodar a criança e os equipamentos. Desse modo, passa a morar junto com o Sr. D., 47 anos, tabagista, portador de gastrite crônica, ensino fundamental incompleto ( $4^{\circ}$ ano), mestre de obras, e a Sra. A., 43 anos, tabagista, nódulo mamário em tratamento, ensino fundamental incompleto ( $3^{\circ}$ ano), diarista. 
A renda familiar média é em torno de três salários mínimos por mês, renda proveniente do benefício social e do trabalho do pai, renda destinada a manutenção das necessidades da mãe e dos seus filhos. A renda dos avôs não é contabilizada, visto que é destinada a manutenção de suas despesas pessoais e da casa.

E. é migrante da região nordeste do país. Da família de origem de E. ficaram no nordeste três irmãos e os pais, com os quais mantém contatos telefônicos, e visitas esporádicas, sendo a última visita da mãe de E. na ocasião do nascimento de seu primeiro filho. Em São Paulo, vive seu irmão mais velho (39 anos), casado e com três filhos, como representante de sua família extensiva.

L. é natural de São Paulo, e tem uma irmã L., 20 anos, casada, ensino médio, caixa de restaurante; e um irmão, A., 19 anos, ensino médio, garçom. Grande parte da família extensiva de L., mora próxima a sua residência, muitos na mesma rua.

$\mathrm{Na}$ ocasião da entrevista, estavam presentes os pais e os filhos, ambos os pais participaram. Além do encontro para a realização da entrevista, foram realizados outros contatos durante o acompanhamento das visitas da equipe de assistência domiciliar. Ao todo foram três contatos com a família, sendo dois antes e um após a entrevista. Nesse ultimo encontro, foi possível, saber que o casal havia se reconciliado e estavam reformando a antiga casa, contigua a casa dos pais da L, para voltarem a viver juntos e sua própria casa.

\section{Família 3}

Família procedente da Zona Oeste da cidade de São Paulo, residente em uma comunidade de baixa renda inserida em meio um bairro de classe média alta. 
A família é composta pela mãe S., 34 anos, ensino médio, exoperadora de microfilmagem (deixou o trabalho para cuidar da filha doente), atualmente do lar e principal cuidadora da criança com necessidades especiais de saúde, portadora de Hipertensão Arterial Sistêmica e depressão em tratamento; pelo pai, A., 31 anos, ensino médio incompleto ( $2^{\circ}$ ano), ajudante de mecânico, saudável; casados consensualmente há oito anos. Possuem juntos dois filhos, J. um menino de 6 anos, estudante da $2^{\text {a }}$ fase do EMEI, e $\underline{\mathbf{S}}, 2$ anos, portadora de Síndrome de Werdnig-Hoffman, diagnosticada aos 3 meses de idade; permanecendo hospitalizada por um período de 10 meses, entre 3 meses e 1 ano de idade, tornando-se dependente de tecnologia de suporte de vida nesse período, atualmente, é dependente de traqueostomia, gastrostomia e ventilação mecânica e é cuidada, em casa, pela família há 10 meses.

Além dos dois filhos do casamento atual S. possui mais três filhos de relacionamentos anteriores, que residem na mesma casa, sendo L., um menino de 20 anos, ensino médio incompleto ( $1^{\circ}$ ano), desempregado, saudável; L., menino de 13 anos, estudante do $5^{\circ}$ ano do ensino fundamental, saudável; e S. uma menina de 10 anos, estudante do $4^{\circ}$ ano do ensino fundamental, saudável.

S. refere não ter contato e nem ajuda financeira dos pais dos dois filhos mais velhos, dos quais se separou ainda durante a gravidez. O pai de L. morreu vitima de assassinato, há 16 anos. A filha $\mathrm{S}$. de 10 anos tem contato esporádico com o pai, e recebe eventualmente o valor de 150 reais de pensão.

A renda familiar mensal varia em torno de três salários mínimos, renda proveniente do beneficio social e do trabalho de $\mathrm{A}$.

Os pais do A. são casados e moram próximos a casa da família, na mesma rua; Sr. C., 50 anos, pedreiro, alcoólatra e Sra. S., 61 anos, aposentada e trabalha como babá ("cuida de três crianças em casa de família"). A. tem duas irmãs, A. de 32 anos, e N. de 33 anos, que é casada com o irmão de S., F. de 38 anos, mecânico, e tem um filho A. de 8 anos. 
O Pai da S. é falecido há 20 anos, vítima de doença de chagas, e a mãe Sra. A., 58 anos, aposentada, portadora de diabetes e Hipertensão, mora na mesma rua junto com o filho mais novo D. de 20 anos, ensino médio, desempregado. A Sra. A. teve outros cinco filhos que nasceram mortos ou morreram logo após o nascimento, sendo a causa da morte desconhecida.

A casa da família é contigua a casa de outra família. O espaço é pequeno, os filhos dormem em um mesmo quarto e o espaço da criança doente fica junto ao quarto do casal, um cômodo único localizado no piso superior da residência. A família está reformando a casa, com a ajuda do Sr. C. (avô paterno que é pedreiro). Estão ampliando o espaço e planejam mudar o quarto do casal para o térreo, para facilitar o cuidado e o transporte da criança que é dependente de tecnologia.

$\mathrm{Na}$ ocasião da entrevista, estavam presentes a mãe, e os filhos. A mãe foi a informante principal, as informações na perspectiva dos irmãos foram obtidas a partir de conversas informais ao longo das visitas domiciliares e, portanto, compõe as notas de observação.

\section{Família 4}

Família procedente da Zona Oeste da cidade de São Paulo, residente em uma comunidade de baixa renda, inserida em meio a um bairro de classe média alta.

Composta pelo pai, F., 27 anos, ensino fundamental, balconista de padaria, saudável; pela mãe S., 31 anos, ensino fundamental incompleto ( $7^{\circ}$ série), ex-auxiliar de limpeza, atualmente do lar (parou de trabalhar quando a filha nasceu). São casados consensualmente há 11 anos e tem uma filha, ㄴ. 9 anos, que é portadora da doença de Niemann-Pick tipo $\mathrm{C}$, diagnosticada aos 2 anos e 6 meses de idade. Com a progressão da doença, a criança tornou-se dependente de tecnologia. Atualmente, é dependente de 
gastrostomia, traqueostomia e de ventilação mecânica. Ao tornar-se dependente de ventilação mecânica (aos 6 anos de idade), a criança permanece hospitalizada durante 1 ano e 2 meses e, após esse período, foi feita a transição para o cuidado domiciliar. Recebe cuidado em casa dos pais há 1 ano e 5 meses.

Os avôs maternos, Sr. J. e Sra. S., são separados há 25 anos. O Sr. J. tem 82 anos, aposentado, mora em Taboão da Serra junto com os três filhos mais novos (E. 26 anos, A. 18 anos e L. 17 anos), frutos de relacionamentos posteriores à separação. A Sra. S. tem 53 anos, recebe beneficio do INSS por problemas psiquiátricos, mora no mesmo terreno, aos fundos da casa da família. Além de S. o casal teve outra filha C., 33 anos, ensino médio, ajudante de Centro de Educação Infantil (CEI). C. mora em Taboão da Serra, é casada com B., 48 anos, ensino superior, segurança noturno, e tem dois filhos $R$. uma menina de 10 anos, estudante $4^{\circ}$ ano, EF, e N. um menino de 3 anos, frequenta CEI. S. tem outras duas irmãs por parte de pai, H., 56 anos, casada, tem três filhos, mora no Jaguaré e E., 53 anos, viúva, tem três filhos, mora em Carapicuíba.

S. tem contato com todos os irmãos, mas tem maior intimidade com a irmã C. e sua família.

Os avôs paternos são separados cerca de 10 anos. O avô Sr. A. tem 54 anos, $3^{\circ}$ ano do ensino fundamental, vigia, saudável. A Avó, $\mathrm{Sr}^{\mathrm{a}}$. M., tem 41 anos e não tem notícias dela.

F. tem um irmão, Fl. de 24 anos, ensino médio incompleto ( $2^{\circ}$ ano), montador de móveis; e uma irmã Fa., de 20 anos, ensino médio incompleto ( $2^{\circ}$ ano), do lar, casada com E. 21 anos, ensino fundamental, operário, e tem um filho K. de 2 anos, frequenta CEl.

O pai de $F$. e seus irmãos moram na mesma comunidade. E tem intimo relacionamento com a família, sendo a irmã de F. a principal fonte de apoio para o casal. 
A casa da família é pequena, possui três cômodos, sendo o quarto do casal, o quarto da criança, cozinha e banheiro, distribuídos em dois pisos, o que dificulta o transporte da criança por conta das escadas. A renda familiar varia em torno de dois salários mínimos, renda proveniente do beneficio social e do trabalho de F.

$\mathrm{Na}$ ocasião da entrevista, estavam presentes, o casal e a filha. Além do encontro para a realização da entrevista, outros dois encontros ocorreram durante a visita da equipe de assistência domiciliar.

\section{Família 5}

Família procedente da Zona Oeste da cidade de São Paulo, residente em um bairro de classe baixa.

A família é composta pela mãe F., 33 anos, saudável, ensino médio, atualmente do lar e principal cuidadora da criança, pelos seus filhos, S. uma adolescente de 14 anos, estudante do $1^{\circ}$ ano do ensino médio, saudável, filha do primeiro casamento; e L. um menino de 10 anos, estudante do $4^{\circ}$ ano do ensino fundamental, faz acompanhamento ambulatorial para controle de rinite e sinusite, $\underline{\mathbf{M}}$ uma menina de 5 anos, portadora de Síndrome de West, secundária a complicações da prematuridade, acamada, dependente de gastrostomia, traqueostomia e oxigenoterapia contínua, e E., uma menina de 2 anos e 6 meses, frequenta o centro de educação infantil no período da tarde, portadora de imunodeficiência de imunoglobulina $A$, atraso no crescimento pondero-estatural, faz acompanhamento.

F. é divorciada do pai de sua filha mais velha há 11 anos. No entanto, refere que o pai preserva suas responsabilidades, funções e cuidados paternais em relação à menina. Com relação ao segundo casamento, F. foi casada, consensualmente, por dez anos com o pai dos três filhos mais novos e está separada há quadro meses. A separação conjugal ocorreu em 
meio à última hospitalização da criança com necessidades especiais de saúde. Atualmente o pai está preso.

Além de seus filhos, F. considera como parte de sua família seus pais, apesar de não morarem juntos. Os avôs maternos Sr. F., 79 anos e Sra. M.53 anos, são casados há 35 anos. O Sr. F., possui ensino médio, trabalha como autônomo, também é cardiopata e portador de câncer de pele e está em constante tratamento. A Sra ${ }^{a}$. M., possui ensino médio, é tabagista e do lar. Os avôs residem em Barueri e são responsáveis pelo sustento econômico da unidade familiar.

F. refere ter íntimo contato e contar com o apoio de sua avó (bisavó das crianças) H., 71 anos, aposentada, reside em Santos. A casa da bisavó é o lugar onde a família se reúne para passar férias e datas comemorativas.

F. tem três irmãs por parte de pai, S., 54 anos, S., 50 anos, e C., 46 anos, com as quais refere ter apenas contato social.

Os avôs paternos da filha mais velha residem em São Paulo e mantém íntimo contato com a neta. Os avôs paternos dos três filhos mais novos residem na região norte do país e a mãe não têm contato nem informações sobre eles.

A criança tornou-se dependente de tecnologia aos três anos de idade. Atualmente, é acamada, dependente de gastrostomia, traqueostomia e oxigenoterapia contínua. Nesse período, a criança passou por várias internações recorrentes e última hospitalização teve a duração de quatro meses ocasião em que foi realizada a cirurgia de traqueostomia e transição para o cuidado domiciliar. É cuidada em casa há dois meses pela mãe, com suporte de serviço público de assistência domiciliar.

A casa é ampla e adequada às necessidades da família. Localiza-se em uma rua de fácil acesso e próxima a serviços de saúde.

Estavam presentes na ocasião da entrevista a mãe, a avó materna e os filhos. A mãe foi a informante principal, a avó complementou as 
informações e os dados obtidos com as crianças compuseram as notas de observação.

\section{Família 6}

Família procedente da Zona Oeste da cidade de São Paulo, residente em condomínio residencial localizado em um bairro de classe baixa.

A família é composta pelo pai, R., 28 anos, ensino médio, coordenador de expedição de uma distribuidora de tapetes, saudável; pela mãe, C., 30 anos, ensino fundamental incompleto ( $7^{\circ}$ ano), ex-diarista, atualmente do lar; o casal vive uma união consensual há sete anos. São primos de primeiro grau e tem dois filhos com necessidades especiais, A., uma menina de 5 anos de idade, portadora de hiperglicemia não-cetótica, dependente de gastrostomia e acamada e J., um menino de 1 ano e 1 mês, portador da mesma doença, dependente de gastrostomia e de oxigenoterapia contínua via cateter nasal e acamado. C. tem outro filho, fruto de união anterior, P., um menino de 9 anos de idade, saudável, estudante do $4^{\circ}$ ano do Ensino Fundamental.

Com relação às crianças com necessidades especiais, ambas viveram hospitalização prolongada, do nascimento até 1 ano de idade. A menina é cuidada em casa pela mãe há quatro anos, sem suporte de serviço de assistência domiciliar. A criança perdeu o direito a ser assistida pelo serviço público por mudar da área de abrangência do programa. O menino é cuidado em casa pela mãe, há dois meses, com suporte do serviço público de assistência domiciliar, devido o retorno da família para a área de abrangência do programa e o nascimento da criança ter se dado no hospital onde o programa é implantado.

O casal é migrante da região nordeste do país. Da família de origem do R., ficaram no nordeste seus pais e parte dos seus irmãos. Dois irmãos residem em São Paulo em bairros próximos à residência da família. Da 
família de origem da C. ficaram no nordeste seu pai e os irmãos por parte de pai, com os quais perdeu o contato. Dos irmãos por parte de mãe, dois ficaram no nordeste, e mantêm contatos esporádicos e duas moram em São Paulo junto com a mãe, em bairro periférico da Zona Oeste de São Paulo. Uma das imãs de C., que migrou junto para São Paulo, morreu em janeiro de 2009, devido a choque séptico após uma tentativa de aborto, deixando três filhos pequenos, que são criados pela avó. A avó materna, Sr ${ }^{a}$. E., 50 anos, faz tratamento para problemas psiquiátricos, portadora de atrite reumatóide e trabalha como diarista.

O apartamento da família é amplo e adequado às necessidades do grupo. No entanto, a família enfrenta sérias restrições financeiras para poder pagar o aluguel como forma de garantir conforto para as crianças doentes. A renda familiar varia em torno de três salários mínimos.

Estavam presentes no momento da entrevista a mãe e os filhos. A participação do pai foi impossibilitada pela jornada de trabalho que abarcava, inclusive, os finais de semana.

\section{Família 7}

A família é procedente da Zona Oeste da cidade de São Paulo, residente em um bairro de classe baixa. A casa da família situa-se de forma contígua à de outra família.

A família é composta pelo pai, R., 25 anos, estudante do $6^{\circ}$ ano do ensino fundamental, auxiliar de serviços gerais; pela mãe, S., 29 anos, ensino médio, ex-supervisora de lotérica, atualmente, do lar, faz tratamento para depressão. $\mathrm{O}$ casal vive em união consensual há três anos e tem uma filha E.., uma menina de 2 anos e 6 meses de idade, portadora de Síndrome de West. A criança viveu várias hospitalizações recorrentes e tornou-se dependente de tecnologia com 1 ano e 2 meses de idade, ficando hospitalizada por 4 meses e, após esse período, foi feita a transição para o 
domicílio. Atualmente é dependente de oxigenoterapia contínua, via cateter e, mais recentemente, de gastrostomia, realizada em novembro de 2009, pouco antes da realização da entrevista. Antes era alimentada por sonda naso-jejunal. É cuidada em casa pela mãe há um ano, com suporte do serviço público de assistência domiciliar realizado por equipe multiprofissional.

Residem juntos com o casal e a filha, o tio paterno, R., 28 anos, ensino fundamental, metalúrgico.

O casal é migrante. O pai do nordeste, Pernambuco e a mãe do sudeste, do Espírito Santo.

Os avôs paternos são falecidos, o avô em 2008, secundário a Infarto Agudo do Miocárdio e a avó em 1996, sendo a causa da morte desconhecida. O pai tem três irmãos, além daquele que mora em sua casa, outros dois residem em São Paulo, na zona norte.

O avô materno é falecido, em 2004. A mãe refere não saber a causa da morte, devido a não ter tido convivência com o pai. A avó materna, Sr. L, 47 anos, ensino fundamental básico, faxineira de condomínio, é separada do pai de S. há 23 anos e mora em Vitória no Espírito Santo. S., possui dois irmãos, S. 27 anos, casado, técnico em engenharia elétrica, que continua morando em Vitória/ES, e F. de 23 anos, casado, com um filho, estudante de ciências contábeis, trabalha como cozinheiro e residente em São Paulo em um bairro próximo.

A renda familiar varia em torno de dois salários mínimos, proveniente tanto do beneficio social como do trabalho do pai.

Na ocasião da entrevista, estavam presentes, a mãe e a filha. O casal está vivendo uma separação conjugal e o pai "não quis participar" segundo a informação materna este não participa da vida da criança. 


\section{Família 8}

Família procedente da Zona Sul da cidade de São Paulo, residente em uma comunidade pobre, inserida em meio a bairros de classe média baixa.

A família é composta pelo pai, Z., 38 anos, ensino fundamental incompleto ( $4^{\circ}$ ano), trabalha como cozinheiro em restaurante, saudável; pela mãe S., 30 anos, estudante do $4^{\circ}$ ano do ensino fundamental, do lar; são casados, consensualmente, há 12 anos. O casal possui um filho, $\underline{\mathbf{U}}$, um menino de 9 anos, estudante do $2^{\circ}$ ano do ensino fundamental, portador de pneumopatia crônica secundária a bronquiolite obliterante que o acometeu logo após o nascimento. Atualmente, é dependente de oxigenoterapia contínua via cateter nasal.

A criança é considerada uma criança em estado grave, e frequentemente precisa de atendimento de emergência, devido a obstrução pulmonar e parada respiratória. Passou por várias internações longas até os 6 anos de idade e foi dependente de gastrostomia até os 7 anos.

Atualmente, a criança se comunica com muita dificuldade, tem acentuados comprometimentos motores e cognitivos, anda com dificuldade e não consegue pegar objetos ou comer sozinha. Possui dispositivo de oxigênio portátil e transporte especial, ambos os recursos da prefeitura, para poder frequentar a escola.

A criança é cuidada em casa pelos pais há oito anos, com suporte de serviço privado de atendimento domiciliar, os diferentes profissionais, como nutricionista, fonoaudióloga, fisioterapeuta e médico pediatra, vinculados a diferentes serviços de assistência domiciliar, realizam o atendimento da criança em seu domicílio.

O casal é migrante da região nordeste do país, ambos da Bahia, sendo primos em segundo grau. Ambos possuem uma vasta rede de parentes residindo na mesma rua de sua casa. 
Da família materna, migraram para São Paulo e residem na mesma rua, sua avó materna, Sra . E., 67 anos, saudável, residente há 1 ano em São Paulo; a mãe, Sra. M., 50 anos, viúva, ensino fundamental básico, diarista e saudável, e seu irmão, R., 26 anos, casado com R. de 24 anos. O pai da S. morreu em 2001, secundário a infarto agudo do miocárdio. S. tem mais quatro irmãos por parte de pai, todos residentes na Bahia, e com os quais tem pouco contato.

Da família paterna, os avôs permaneceram na Bahia, o Sr. A, aposentado, saudável e a Sra. E., 55 anos, do lar, saudável. O casal de avôs têm juntos 12 filhos, incluindo o Z. (pai). Destes onze irmãos de Z., oito residem em Valinhos, interior de São Paulo e dois residem na mesma rua de sua casa e uma irmã, V. 23 anos, mora numa casa contígua à da família.

A casa da família é pequena, mas adequadas as necessidades do grupo. U. tem seu próprio quarto, mas dorme no quarto do casal. A renda familiar varia em torno de três salários mínimos, proveniente do trabalho paterno e do beneficio social.

Estavam presentes na ocasião da entrevista o casal e o filho.

\section{Família 9}

Família procedente do município de Diadema, residente em um bairro periférico, de classe baixa, próximo à divisa com a Zona Sul de São Paulo.

A família é composta pelo pai J., 41 anos, ensino fundamental incompleto (5aㅡ ano), trabalha como segurança em escola municipal; pela mãe R., 45 anos, ensino médio, ex-auxiliar de enfermagem (deixou o emprego na ocasião da doença da filha), atualmente, do lar e principal cuidadora da criança com necessidades especiais; São casados há 5 anos e possuem juntos uma filha, ㄴ. de 4 anos, portadora de paralisia cerebral, secundária à infecção gestacional por Citomegalovírus. A criança passou por várias hospitalizações em Unidade de Terapia Intensiva Pediátrica desde o 
nascimento. Tornou-se dependente de gastrostomia aos 2 anos de idade; antes, era alimentada por sonda naso-jejunal. Atualmente, está acamada, não se comunica, faz uso de anticonvulsivantes e frequenta escola especial. A escola e o transporte escolar são recursos públicos concedidos pela prefeitura local.

Além do casal e a filha, reside na casa um tio materno, R., 47 anos, ensino médio, fiscal de transporte metropolitano, saudável.

O pai possui um filho de 14 anos, estudante do $7^{\circ}$ ano do ensino fundamental, saudável; fruto de seu primeiro casamento. O menino reside com a mãe, mas mantém íntimo contato no núcleo familiar do pai.

A criança com necessidades especiais de saúde é cuidada, em casa, pelos pais há 3 anos e 6 meses, com suporte de serviço privado de assistência domiciliar. A criança é atendida em casa por diferentes profissionais, tais como: nutricionista, fonoaudióloga, fisioterapeuta e médico pediatra, todos vinculados a diferentes serviços de assistência domiciliar.

O avô paterno faleceu em 2005, em decorrência de hemorragia intestinal. A avó, Sr ${ }^{\text {a }}$. A., 65 anos é aposentada e portadora de hipertensão e cardiopatia, casou-se novamente em 2008 com Sr. J., 65 anos, pedreiro, saudável. O casal reside em Jaú, interior de São Paulo.

J. (pai) possui três irmãos, dois residentes em São Paulo e uma irmã residente em Jaú. Uma de suas irmãs faleceu em 2008, vítima de acidente vascular cerebral.

A avó materna faleceu em 1997, devido a um infarto agudo do miocárdio. O avô materno, Sr. E., 70 anos, aposentado e saudável, casou-se novamente no ano de 2000, com M., 60 anos, do lar. O casal reside em Belo Horizonte/MG, cidade natal do avô materno, para a qual retornou após longo tempo vivido em São Paulo. 
Além do irmão que reside junto com a família, a mãe possui outro irmão C., 40 anos, engenheiro mecânico, casado, tem duas filhas adolescentes e residentes em bairro próximo à casa da família.

A casa que a família reside era dos avôs maternos, é adequada às necessidades de conforto e segurança do grupo. O trabalho do pai é próximo à residência. $\mathrm{E}$ a família tem parentes e vizinhos de longa data, na rua onde vive. A renda familiar varia em torno de três salários mínimos, proveniente do trabalho paterno e do beneficio social.

Estavam presentes na ocasião da entrevista a mãe, a filha e o tio materno. O pai não pode participar pela jornada de trabalho e indisponibilidade da família para a realização da entrevista no final de semana, os quais costumam passar no interior de São Paulo.

\section{Família 10}

Família procedente do município de Diadema, residente em um bairro periférico, de classe baixa.

A família é composta pelo pai, N., 46 anos, ensino médio, mecânico, estudante de técnico em mecatrônica; pela mãe M., 40 anos, ensino médio, operadora de máquina em empresa de confecção de tapetes automotivos, saudável. São casados há 19 anos, e possuem dois filhos, G., um menino de 15 anos, estudante do $1^{\circ}$ ano do ensino médio e portador de bronquite; e P. um menino de 1 ano e 7 meses de idade, portador de Sequência de Pierre Rubin. A criança nasceu com malformação congênita cardíaca e fenda palatina. Ficou hospitalizada em UTI neonatal por dois meses e, após esse período, recebeu alta para o cuidado domiciliar. Com 1 ano de idade, tornouse dependente de gastrostomia; antes se alimentava via sonda naso-jejunal e com 1 ano e 6 meses fez a cirurgia corretiva da fenda palatina. Atualmente, a criança é acamada e não fala. É cuidada, em casa, há 1 ano e 5 meses, pelos pais e, no período de trabalho materno, pela avó paterna. 
Faz acompanhamento especializado em serviço público, localizado a 200 $\mathrm{Km}$ da residência da família.

Os pais dispõem de serviço particular de atendimento domiciliar, mas apenas as consultas médicas e de fonoaudiologia são realizadas no domicílio. Os demais tratamentos são oferecidos em clinicas especializadas e os pais têm que levar a criança.

A casa da família localiza-se contígua a casa dos avôs paternos, Sr. T. 78 anos, aposentado e hipertenso, e Sra. G., 77 anos, aposentada e portadora de osteoporose.

Os avôs maternos são falecidos. A avó no ano de 2003, em decorrência de acidente vascular cerebral e o avô, em 2006, devido à infecção generalizada secundária a traqueostomia. A mãe é migrante de Minas Gerais e tem sete irmãos, destes apenas uma irmã. M. de 42 anos, reside na região metropolitana de São Paulo, os demais permanecem em Minas Gerais. O pai é natural de São Paulo e tem quatro irmãos, todos morando perto de sua residência.

A renda familiar varia em torno de quatro salários mínimos. A família não possui o beneficio social. Recebe da prefeitura ajuda financeira para o custeio das passagens de um dos acompanhantes da criança para a ida ao centro especializado.

Estavam presentes, na ocasião da entrevista, o casal e os filhos.

\section{Família 11}

Família procedente da Zona Sul da cidade de São Paulo, residente em uma comunidade de baixa renda.

A família é composta pelo pai P. G., 30 anos, ensino fundamental incompleto ( $4^{\circ}$ ano), encanador, saudável; pela mãe, G., 26 anos, do lar, saudável; casados há sete anos, e têm uma filha $\underline{\underline{L}}$, de 6 anos, portadora de 
Distrofia Muscular tipo II, diagnosticada com 1 ano de idade. A criança tornou-se dependente de gastrostomia aos 2 anos de idade e de traqueostomia e ventilação mecânica aos 3 anos de idade, quando permaneceu hospitalizada por 11 meses. Após esse período foi realizada a transição para o cuidado domiciliar. A criança é cuidada em casa pelos pais há três anos, e não dispões de suporte formal ou vínculo com serviços de atendimento domiciliar. A família paga fisioterapia domiciliar para a criança, como um meio de evitar reinternações.

O casal é migrante da região nordeste do Brasil, da zona rural da Bahia. Os avôs paternos moram na Bahia, Sr. D., 70 anos, aposentado, agricultor, depressivo e a Sr ${ }^{\text {a }}$ D., 66 anos, aposentada, saudável. O casal de avôs teve 15 filhos, destes dois morreram recém-nascidos, parte dos filhos mora no estado de São Paulo, na capital e, em Valinhos, e outra parte permanece na Bahia.

Os avôs maternos também moram na Bahia, Sr. A., 75 anos, aposentado, agricultor, hipertenso e a Sra. M., 63 anos, aposentada, portadora de artrite reumatóide. O casal teve 10 filhos, dois morreram na infância, tendo como causas diarréia e sarampo. Das sete irmãs maternas, duas moram em São Paulo, no mesmo terreno; três em Valinhos e duas permanecem na Bahia.

A renda familiar varia em torno de dois salários mínimos. Renda proveniente do trabalho paterno e composta com o beneficio social.

Estavam presentes, na ocasião da entrevista, o casal e a filha. 


\subsubsection{Análise dos dados}

A análise dos dados seguiu as fases preconizadas pelo método comparativo constante da Teoria Fundamentada nos Dados ${ }^{(116)}$. O método comparativo constante permite estabelecer distinções analíticas e assim realizar comparações a cada nível do processo analítico.

$\mathrm{Na}$ primeira fase analítica, é realizada a codificação inicial ou codificação aberta dos dados, em que os fragmentos de dados são estudados rigorosamente, palavras, linhas, segmentos e incidentes são questionados e comparados.

$\mathrm{Na}$ codificação inicial segmentos de dados recebem uma denominação concisa que, simultaneamente, sintetiza e representa cada parte dos dados. Esses segmentos de dados são chamados de códigos, e permite a seleção, a classificação e a separação dos dados para a interpretação analítica.

Desse modo, procedeu-se a leitura atenta dos dados e cada entrevista foi quebrada em pequenos pedaços (incidentes), examinada e questionada, linha a linha, buscando a denominação de cada segmento de dados e a descoberta das primeiras propriedades analíticas dos dados, representativas dos significados contidos nos segmentos de dados. Conforme o Quadro 1, de uma codificação linha a linha.

Quadro 1: Exemplo de codificação inicial, linha a linha.

\begin{tabular}{|c|c|}
\hline Trecho da entrevista & Códigos \\
\hline $\begin{array}{l}\text { [...] a desvantagem era saber que ela (filha) } \\
\text { estava no hospital, e que a gente não podia } \\
\text { fazer nada e... tornar isso vantagem é estar } \\
\text { junto, fazer tudo junto e... lutar junto para } \\
\text { poder ter trazido ela (filha) para casa... né?, } \\
\text { mesmo sabendo que no começo, quando } \\
\text { ficamos sabendo que era praticamente } \\
\text { impossível..., mas a gente... deu a volta por } \\
\text { cima, bateu um pouco... esta certo... não } \\
\text { vamos dizer que né?, não deixou marcas, } \\
\text { vamou um pouco..., mas assim, que nem eu } \\
\text { deixou falei por causa da pressão que foi } \\
\text { te alocada, acho que muito premeditada em } \\
\text { colocada gente, né? }\end{array}$ & $\begin{array}{l}\text { Sendo uma desvantagem ter a filha } \\
\text { hospitalizada } \\
\text { Sabendo que não poderiam fazer nada pela } \\
\text { filha } \\
\text { Transformando a desvantagem em } \\
\text { vantagem } \\
\text { Estando juntos } \\
\text { Lutando juntos para trazer a filha para casa } \\
\text { Sabendo que era praticamente impossível } \\
\text { trazer a filha para casa } \\
\text { Superando as dificuldades } \\
\text { Ficando marcas } \\
\text { Sentindo-se pressionados de forma } \\
\text { precipitada }\end{array}$ \\
\hline
\end{tabular}


A codificação inicial permite que o pesquisador se mantenha aberto a todas as direções teóricas possíveis indicadas na leitura dos dados. Desse modo, é possível, mediante constante exercício reflexivo, ir determinando o que ocorre nos dados e dar sequência ao processo de busca e análise de dados.

Após a codificação inicial, a codificação na Teoria Fundamentada torna-se mais focalizada. Os códigos iniciais passaram por um novo processo de comparação. Dessa maneira, os códigos foram comparados entre si e códigos mais significativos foram comparados com grande quantidade de dados. Esse nível do processo de comparação permitiu classificar e integrar os códigos de acordo com suas propriedades analíticas.

Os códigos conceituais foram agrupados de acordo com suas similaridades e suas diferenças. Esta etapa permitiu detectar e desenvolver as primeiras categorias contidas nos dados, conforme exemplifica o Quadro 2.

Quadro 2: Exemplo de categorização dos dados.

\begin{tabular}{|l|c|}
\hline \multicolumn{1}{|c|}{ Códigos } & Categoria \\
\hline \hline \hline Persistindo na decisão de voltar com o filho para casa & \\
Fazendo de tudo para poder voltar com o filho para casa & Lutando para voltar \\
Tendo que resistir & com o filho para \\
Encarando os desafios & \multicolumn{1}{c|}{ casa } \\
Empenhando-se vinte e quatro horas & \\
Mobilizando os recursos & \\
Sendo determinados & \\
Não ficando parados pensando se seria difícil & \\
Mobilizando forças inimagináveis & \\
Agarrando-se às todas as possibilidades & \\
\hline
\end{tabular}

Esse momento da análise dá início à integração teórica, que se estenderá nas etapas subsequentes e aponta direcionamentos para a sequência dos dados que serão refinados conforme se avança o nível de comparação envolvido no processo analítico, de forma a obter-se uma progressiva compreensão do processo representado nos dados. 
Desse modo, as categorias iniciais recebem nomes conceituais provisórios, que têm como característica serem mais abstratos que os códigos que integram. Conforme se avança no processo analítico e novos dados são buscados, as categorias e suas propriedades são comparadas entre si, em com amplos segmentos de dados contidos em diversas partes da entrevista. Assim, as categorias foram questionadas e literalmente postas à prova, foram contrapostas, fragmentadas ou fundidas, de forma a serem reorganizadas, tornarem-se cada vez mais abstratas e expressarem relações conceituais entre si.

Em meio a esse processo comparativo, as ideias analíticas que surgiram sobre as categorias e a possível relação entre os dados foram registradas. Este registro recebe o nome de memorando ${ }^{(117)}$. A redação do memorando é a etapa intermediária fundamental entre a coleta de dados e redação do relatório de pesquisa. A redação de memorandos sucessivos em todas as partes do processo de análise constitui um método crucial na Teoria Fundamentada nos Dados, pois mantém o pesquisador envolvido com os dados e ajuda a elevar o nível de abstração das ideias analíticas.

Os memorandos representam o registro dos pensamentos, das comparações e conexões estabelecidas pelo pesquisador, cristalizam seus questionamentos e as direções que serão buscadas, de forma explicar e densificar as categorias ${ }^{(118)}$. Conforme o exemplo contido no memorando a seguir:

Memorando: sobre a categoria "vivenciando a sobrecarga materna": A sobrecarga materna vivenciada ao longo da experiência de transição parece ser resultante de dois fatores: um interno (self materno - indicações que a mãe faz para si mesma) assumindo para si a responsabilidade integral pelo cuidado da criança (sendo seu dever de mãe) e vendo-se apenas como mãe; e outro contextual - não tendo com quem dividir (independente de ter o companheiro morando junto ou não, pois a responsabilidade e parceria entre os pais é um fenômeno que parece independer de estarem morando juntos, parece ter a ver com as visões e a disponibilidade interna para prover suporte para aqueles que precisam - senso de comprometimento com o bem-estar uns com os outros). Esse movimento de a mãe assumir para si toda a carga faz com que encontre dificuldades para conciliar outras demandas da sua própria vida e da vida dos outros membros da família, vendo-se apenas como mãe, parece representar a invasão da 
situação de ter uma criança com necessidades de cuidados especiais na vida materna, o seu papel de mãe e sua identidade materna se sobrepõem a todos os outros, de mulher/esposa, de filha e de irmã, trabalhadora, restringindo suas possibilidades de ser algo além de mãe ou mesmo ser mãe dos filhos saudáveis. Esse padrão gera instabilidade nos demais relacionamentos familiares, cobranças e sofrimento. As cobranças direcionadas à mãe, por parte dos outros membros da família, especialmente do esposo, são percebidos pela mãe como estressores adicionais, para os quais não vê meios de lidar e se vê ainda mais exigida e sobrecarrega. Existe um ciclo de cobranças externas e autocobrança e sobrecarga e intenso desgaste físico e emocional. Quais a causas e conseqüências desse processo? O que faz com que algumas mães não consigam direcionar a sua própria vida e se afundem no sofrimento, enquanto que outras decidem 'mudar de vida' e recuperar o controle sobre o curso de sua própria vida e da vida familiar? (25 de março, 2010).

O segundo nível de análise na Teoria Fundamenta nos Dados é denominado de codificação teórica ${ }^{(117)}$. Os códigos teóricos são integrativos, e especificam a relação entre as categorias desenvolvidas e explicitam formas de serem integradas em uma teoria.

Nessa etapa do processo, as categorias e as subcategorias foram reorganizadas e integradas em torno de conceitos possíveis de explicar processos psicossociais ou fenômenos centrais que ocorrem nos dados. Então, foram realizadas várias representações gráficas de forma a testar a relação entre as categorias e fenômenos desvelados nos dados, que, por sua vez, conduz à orientação teórica.

$\mathrm{Na}$ última etapa analítica, procurou-se desenvolver o refinamento e a integração teórica entre as categorias, de modo a descobrir a categoria central capaz de representar a compreensão do fenômeno estudado.

Dessa forma, após seguir todas as etapas do método comparativo constante, foi possível construir uma teoria fundamentada nos dados, substantiva, representativa da experiência de vida familiar na transição do cuidado da criança com necessidades especiais de saúde do hospital para o domicílio. 
Resultados

\section{CAPÍTULO IV}




\subsection{APRESENTANDO A HISTÓRIA E O UNIVERSO SIMBÓLICO FAMILIAR}

\section{CONSTRUINDO O PROJETO DE VIDA FAMILIAR}

O movimento de construção do projeto de vida familiar contém aspectos da história e do universo simbólico, os quais ordenam e conferem singularidade, complexidade e dinamizam a vida familiar.

O projeto envolve a noção de liberdade de escolha e de ações deliberadas orientadas a metas pré-estabelecidas. O projeto de vida familiar articula-se à cultura e aos valores fundamentais, incorporados como legados transmitidos pelas famílias de origem, os quais são reafirmados, reconstruídos e reaprendidos diante da sucessão de acontecimentos e de vivências específicas que acompanham a existência de cada família, ao passo que orienta as obrigações e expectativas para o futuro.

O projeto de vida familiar se manifesta mediante ações e interações familiares, estruturadas pelo tempo e pelo espaço da família. As condições de vida são determinantes na forma como a família estabelece e viabiliza seu projeto e vai, paulatinamente, organizando o viver e construindo uma história familiar.

O projeto de vida familiar envolve a união de indivíduos com valores, objetivos e trajetórias de vida que podem revelar semelhanças ou divergências. As circunstâncias pelas quais o núcleo familiar é gerado influenciam sua construção.

O projeto que atribui sentido e aporta a vida familiar, pois promove ligações com a história, com a memória, com a identidade individual e coletiva. O projeto integra os planos para o futuro, como um processo a ser construído, que parte dos meios que a vida concreta proporciona e envolve componentes emocionais, um conjunto de possibilidades e diferentes níveis de sonho e fantasia. 
Cada sistema familiar vive um tempo específico em sua trajetória e organiza o viver, criando um espaço relacional que lhe é próprio, com maior ou menor grau de individualização, permeabilidade e de vinculação com seu entorno social, o qual, por sua vez, afeta a disponibilidade de suporte para a viabilização de seu próprio projeto.

Em sua essência, o projeto é dinâmico, visto que é um processo que se manifesta nas interações familiares e, como tal, envolve o alinhamento de ações individuais. Desse modo, cada projeto individual está sujeito à ação dos outros com os quais é partilhado, ao mesmo tempo em que projetos coletivos ou individuais estão sujeitos às mudanças, substituições, interrupções e transformações, conforme as circunstâncias de vida se alteram.

O projeto de vida é elaborado e construído em função de experiências sociais e culturais. Ele determina o movimento dos indivíduos e do sistema familiar, ao longo do tempo, no sentido de torná-lo viável e de transformá-lo em resultados concretos.

Portanto, o projeto de vida familiar é estabelecido no movimento BUSCANDO O FUTURO SONHADO. O TRABALHO, A CASA, OS VÍNCULOS e O APOIO SOCIAL são os meios empregados para viabilizar e para concretizar tal projeto. O projeto, articulado aos meios empregados para sua construção, revela as formas expressivas do CUIDADO nas ações e interações familiares interconectadas com o trabalho, a casa e a comunidade como elementos simbólicos estruturantes das relações familiares, dos papéis sociais e dos padrões de comportamento.

O significado que cada sistema familiar expressa no movimento BUSCANDO O FUTURO SONHADO dependerá das condições contextuais concretas de vida, dos planos estabelecidos e das interações interpretadas. Enquanto que para alguns indivíduos e sistemas familiares significa buscar ascensão social, representada pela oportunidade de acesso a bens e serviços, para outros significa buscar condições de sobrevivência, seja esta física ou relacional, quando as restrições e os conflitos emergem em função 
de expectativas e sonhos que se tornam difíceis de serem realizados no contexto da vida familiar.

Entretanto, BUSCANDO O FUTURO SONHADO está pautado na crença em si mesmos, na possibilidade de ser e se ter mais na vida, na crença de que a vida pode ser mais digna e o futuro mais promissor.

A forma como o projeto de vida é construído dependerá do tempo e do espaço familiar, bem como das circunstâncias de vida particulares de cada sistema familiar, os quais determinam movimentos diferenciados frente aos desafios sociais que encontram em sua trajetória de se viver e construir juntos, da forma como organizam a vida cotidiana e lutam para a garantia do bem-estar de seus membros.

\section{O TRABALHO}

BUSCANDO O FUTURO SONHADO envolve ações de luta por uma vida melhor. Lutar por uma vida melhor é um movimento e um valor herdado das gerações anteriores, simbolizado pelo valor moral do trabalho. O valor do trabalho é incorporado à vida dos indivíduos que compõem o sistema familiar desde muito cedo, sendo comum o abandono dos estudos, assim que se tornam aptos a partilhar com suas famílias da força de trabalho.

O valor do sacrifício como meio de alcançar uma vida digna, simbolizada pelo o respeito, o reconhecimento, a honestidade e a recompensa gerada pelo próprio esforço se associam ao trabalho e introduzem códigos de conduta ética às ações e interações estabelecidas entre o sistema familiar e seu ambiente.

Nesse contexto, trabalho e cuidado se inter-relacionam, se complementam e são conduzidos ao longo da história de vida familiar, como um modo de organização interacional em torno de deveres e obrigações mútuas. 
[...] eu sempre..., eu nunca desde novinha, eu nunca pedi nada para ninguém (choro, fala com dificuldade), tipo... quando eu morava lá na Bahia, desde pequena assim..., eu não trabalhava, mas eu cuidava da casa, desde os sete anos, eu cuidava da casa, da casa da minha mãe e dos meus irmãos todos e a minha mãe chegava estava tudo limpo, tudo bonitinho, então ela trazia as coisas para mim, então, eu achava que eu estava fazendo por merecer... e quando eu vim da Bahia, eu vim já para trabalhar, eu tinha onze anos, nunca precisei pedir [...] (Mãe, família 6)

[...] eu sempre trabalhei sabe? desde os oito anos de idade, eu comecei trabalhando em casa de família, ia lá ajudava, olhava criança, sabe? E com oito anos eu tinha a mente de hoje uma criança de quinze mais ou menos sabe? Hoje uma criança de quinze está brincando, né? Eu tinha outro tipo de pensamento, meu pensamento era ajudar minha mãe, sabe? Ela ter orgulho de mim [...] (Mãe, família 7)

Em determinadas circunstâncias, BUSCANDO O SONHADO implica em movimentos sociais de migração. Quando o ambiente sócio-geográfico em que vivem não lhes oferece opções dignas de trabalho, de saúde ou de sobrevivência, surge, então, a necessidade de migrar em busca de trabalho, do sonho de ter mais oportunidades e de ter uma vida melhor na grande cidade. A migração representa uma transição sociocultural transformadora, por gerar rupturas na história e na identidade social, ao mesmo tempo em que adiciona desafios, expõe a fragilidade e desafia as forças na vida dos indivíduos e dos grupos familiares.

A privação socioeconômica gera a necessidade de romper e lutar contra a realidade opressora e, ao mesmo tempo, ceder lugar à opressão, deixando seu lugar de pertencimento, representado pela terra natal e pela rede familiar e social. Ao migrarem, indivíduos e grupos familiares rompem vínculos significativos construídos ao longo de sua história de vida, os quais constituíam sua rede de relacionamento e de apoio social; rompem ainda com a cultura em que construíam e afirmavam suas identidades pessoais e familiares.

Desse modo, o projeto de migração associa-se ao projeto de vida familiar, em função das circunstâncias e contingências sociais e/ou familiares que provocam o movimento BUSCANDO O FUTURO SONHADO. Nesta circunstância, a necessidade de mudança, representada pela 
ausência de opção de sobrevivência em seus lugares de origem, decorre de dois motivos distintos: o movimento opressor da pobreza e a ausência de tratamento para uma doença grave. No último caso, a mudança do núcleo familiar (ou de parte dele) para uma cidade grande, que ofereça os recursos diagnósticos e terapêuticos necessários para a sobrevivência da criança, ocorre simultaneamente ao tempo de vivenciar o surgimento da doença como fato novo na vida da família; fato para o qual os pais não dispõem de informações sobre a doença e, portanto, ao migrarem buscando diagnóstico e tratamento, não fazem ideia dos desdobramentos que possam ter e/ou terão em suas vidas.

Quando ocorrem de forma simultânea, a migração e a doença colocam o sistema familiar no limiar de suas fraquezas e desafiam suas forças diante de uma vida desconhecida.

O impacto das rupturas e dos danos gerados pela migração, como um aspecto da história de vida da família, que pode se manifestar na situação de doença grave da criança, irá depender do tempo decorrido entre o evento de migração e o surgimento da doença, do momento da trajetória de vida que ambos os eventos ocorrem, da habilidade da família reconstruir seu espaço relacional no novo ambiente de vida. Ambiente este representado pelo espaço doméstico, pelos vínculos e pela rede de apoio social; e ainda: da conexão que mantém com sua rede familiar, intra e intergeracional, que sofre diferentes graus de fragmentação em função do movimento de migração e com sua cultura, como forma de manter um senso de continuidade com sua história e identidade. Elementos estes que podem representar tanto as fragilidades, quanto as forças do sistema familiar em seu processo de viver e construir projetos.

No movimento BUSCANDO O FUTURO SONHADO, o sistema familiar vai organizando o viver e tentando manter a continuidade dos valores e um compromisso com a história familiar frente aos desafios que encontra em sua trajetória. 
Assim, BUSCANDO O FUTURO SONHADO, como um processo construído pelas ações e interações do sistema familiar, articula-se ao trabalho e ao cuidado.

Os valores associados ao trabalho são incorporados, como legados transmitidos pelas famílias de origem, os quais se manifestam em função das circunstâncias que são vivenciadas por cada sistema familiar.

O trabalho é o meio de viabilizar o projeto de vida individual e familiar, e nele são depositadas as esperanças para o futuro. $O$ trabalho possibilita 0 viver e o sonhar e integra o universo simbólico de cada individuo e do sistema familiar. Os significados atribuídos ao trabalho variam em função da história individual e da família, do tempo e das circunstâncias vivenciadas. Assim sendo, o trabalho pode ser definido como um meio de independência dos indivíduos em relação à sua rede familiar e da mulher em relação ao homem.

O valor do trabalho para a mulher, como meio de independência em relação ao homem, apresenta-se como uma consequência da fragilidade dos vínculos conjugais experienciados ao longo do tempo como sucessivos abandonos e como ausência de comprometimento dos companheiros com o sustento econômico dos filhos e da unidade familiar.

Como meio de independência, o trabalho pauta-se na necessidade dos indivíduos e do núcleo familiar em diferenciarem-se dos sistemas mais amplos, representados tanto pela família extensiva, quanto pela própria comunidade. Logo, o trabalho promove a individualização do núcleo familiar, por meio da garantia do próprio sustento e do próprio espaço, que possibilitam a construção do projeto de vida familiar.

[...] “... antes das crianças (da união atual), nós brigávamos muito, coisa de ciúmes, mas depois que veio as crianças assim, acabou... é porque eu tinha meus filhos, mas não eram dele, então... e eu era independente, tinha meu carro, tinha minha profissão, então era bem... eu falo para ele (esposo) que ele tinha ciúmes e ele 'que ciúmes o quê?', eu falo 'não, ficava aí se roendo, marcava até os minutos para eu chegar no portão' (risos), era uma briga, dava até raiva... por que eu sempre fui independente e nunca fui de ter horário para chegar em casa, aí 
era (risos)... eu ficava mais brava do que tudo, eu era brava, menina (risos), eu não gostava de tudo ter que dar satisfação, eu era bem assim, hoje em dia eu mudei, mas antigamente, se cobrasse uma satisfação de mim, eu já ficava brava, nossa! eu já falava, 'ah faz o que você quiser, pense o que você quiser', sabe?, eu não queria nem saber..." [...] (Mãe, família 3)

[...] Independência. Sabe?, ser independente, de não depender só do dinheiro dos meus pais, é uma coisa de realização tanto pessoal, profissional, acho que todos os sentidos, acho que a pessoa precisa trabalhar, ela precisa se sentir útil não dentro de casa, como eu sempre fui, ela tem que se sentir útil lá fora [...] (Mãe, família 5)

O trabalho também assume um significado de sendo meio de prover 0 sustento econômico da unidade familiar e, desse modo, a garantia de uma sobrevivência digna. Essa função pode ser partilhada ou individual e dependerá das necessidades e da forma como os papéis são incorporados e negociados dentro do sistema familiar.

Dessa maneira, o trabalho também pode ser um meio de exercer e de legitimar os papéis sociais de homem e de mulher, além de reafirmar as diferenças de gênero e, também: do lugar, dos deveres e das obrigações complementares entre homens e mulheres, dentro do sistema familiar. Neste âmbito, é comum a mulher intercalar suas entradas e saídas no mercado de trabalho, em função das necessidades de cuidado da unidade familiar, que envolvem o cuidado de si mesma, da casa, do marido e dos filhos.

[...] "quando eu casei, eu não trabalhava, porque ele (marido) achava que o que ele ganhava dava para me manter, né? Conseguia o que eu queria, porque eu não tenho obsessão por muita coisa exagerada, só mesmo o básico, então assim ele preferia eu, cuidar da minha casa e cuidar das coisas dele, e a noite o tempo que eu tinha para ele é suficiente entendeu?" [...] (Mãe, família 8)

[...] MÃE: "a gente morava na roça, então, eu fazia era só... arrumar a casa, fazia comida, cuidava das coisas da casa... e ele cuidava dos bichos da terra, da plantação... O PAI continua: ... "eu trabalhava na lavoura, né? Criava alguns animais, cabra, ovelha, porco, tinha umas cabeças de gado... Cuidava da terra, que a gente trabalhava com lavoura e alguns animais... então, mudou bastante, porque lá a gente vivia nisso, né? Cuidar dos animais e da terra, né? Chega aqui... aqui é mais corrido, aqui a gente tem... lá (Bahia), a gente trabalhava para a gente mesmo, aqui a gente trabalha para os outros, então a gente tem um horário para cumprir, então é mais corrido, é... trabalhar e cumprir o 
horário...então se tornou... não digo ruim, mas uma experiência diferente" [...] (Família 11)

[...] "a gente trabalhava, nós dois (casal); antes, quando eu não tinha a A.(filha) e ele (esposo) me ajudava na casa, e eu não precisava naquele tempo... eu acho que eu não precisava tanto como agora. Eu chegava tinha almoço pronto, ele (esposo) chegava mais cedo, porque ele (esposo) trabalhava a noite, quando eu chegava de tarde do trabalho tinha comida pronta, tinha casa limpa" [...] (Mãe, família 6)

[...] "eu trabalhava em casa de família, como diarista e cuidando de criança, depois trabalhei quatro anos na USP, numa empresa de limpeza terceirizada e quando a L. (filha) nasceu eu parei de trabalhar para cuidar dela" [...] (Mãe, família 4)

Assim, o homem pode assumir para si a responsabilidade integral pelo sustento da unidade familiar, ou esta pode ser divida pelo casal, ou pode ser incorporada como uma função exclusiva da mulher, quando esta não dispõe de um companheiro para partilhar de tal tarefa.

Quando esse for o caso, o trabalho como forma de garantir o sustento da unidade familiar, é incorporado pela mulher, passando, portanto, a ser sua obrigação e ela se vê tendo que trabalhar para garantir o sustento de si mesma e daqueles pelos quais se sente responsável, o que inclui seus filhos, quando estes se fazem presentes na unidade familiar e os demais membros da família extensiva com os quais partilha deveres e obrigações mútuas, pois, para trabalhar, precisa do apoio de sua rede familiar para a garantia do cuidado dos filhos e, em troca, provê, por meio de seu trabalho, recursos que são partilhados com aqueles com quem divide o cuidado dos filhos e da casa. Desse modo, o trabalho the permite independência econômica, mas gera interdependência em relação à rede familiar e social.

[...] "Eu trabalhava e eles (filhos) ficavam com a minha mãe, quase não me viam. Eu saia de manhã, eles (filhos) estavam dormindo, chegava tarde da noite e eles (filhos) dormindo, então eles não me viam. Eu trabalhava por produção, então eu trabalhava muito antigamente, eu não tinha muito tempo para as crianças assim, a minha vida era trabalhar, era de segunda a sábado, e domingo às vezes, meio período; chegava em casa era roupa, casa, não saia com eles (filhos), não ficava muito com eles (filhos), e eles sentiam necessidade disso, eles me cobravam muito, eles eram muito chorões... eu não tive muita participação no crescimento deles. Minha vida era trabalhar" [...] (Mãe,família 3) 
O trabalho é uma forma de cuidar e, ao mesmo tempo, é o meio que viabiliza os recursos para o cuidado da unidade familiar. Trabalho e cuidado são, portanto, eixos organizadores da vida familiar, que se manifestam no funcionamento instrumental e expressivo do sistema familiar ao longo do tempo e das circunstâncias de vida. Trabalho e cuidado determinam os movimentos, as ações e interações dos indivíduos, dentro do sistema familiar e na construção de seus espaços relacionais.

Assim, mais que uma obrigação, o trabalho é o que dá sentido à vida e é visto como sendo um meio de obter satisfação pessoal. Os resultados do trabalho trazem satisfação, pautado na percepção de que a vida está melhorando, representada pela possibilidade de acesso aos bens de consumo e aos de serviços como carro, melhores condições de morada e de lazer, computador com acesso à internet e suprir as necessidades individuais e coletivas de proteção e de socialização. Dessa forma, o sentimento de satisfação também se associa à possibilidade de inclusão social.

[...] "Quantos anos eu trabalhei em hospital, ganhei um bom dinheiro, tinha meu carro, viajava para cima e para baixo, comprava roupas, tudo que eu queria, tudo que eu queria eu tinha na mão, dinheirinho no bolso, dinheiro no banco, minha vida inteira eu trabalhei e sempre tive uma vida folgada" [...] (Mãe, família 9)

O trabalho, na qualidade de uma atividade formal que ocorre no âmbito da vida pública, representa um meio de visibilidade e inserção social. Ter um trabalho coloca os indivíduos em um status social diferenciado daqueles que são desempregados e dependentes de outros na comunidade. Ao status de trabalhador, associa-se o sentimento de poder pessoal, representado pelo aumento da possibilidade de acesso a bens, de inserção, de participação e de reprodução social.

Entretanto, para os indivíduos que migraram em busca de trabalho, ele representa mais que inserção, representa uma ancoragem, que traz a sensação de segurança social, ao se perceberem fixando-se a sociedade 
por meio do trabalho. O trabalho retira-Ihes a sensação de estar à deriva na vida e na própria história, sem rumo certo e sem possibilidades de construir um projeto de vida familiar e, ao mesmo tempo, Ihes propicia o sentimento de estar honrando o projeto que deu origem à migração, o que, ao contrário, assume significado de fracasso.

O trabalho exige força e sacrifício pessoal, visto que a baixa escolaridade molda as qualificações profissionais e coloca os indivíduos em uma posição de terem que se submeter à condições de trabalho, por vezes, "árduas". A jornada de trabalho é "dura", "Ionga" e "cansativa" e nem sempre representa estabilidade. É comum os indivíduos iniciarem sua trajetória no mundo do trabalho com um subemprego, caracterizado por vínculo informal. Com o tempo e a aquisição de qualificação, o trabalho pode evoluir para um emprego formal, com garantia de direitos, benefícios sociais e melhores rendimentos, assim como, pode também gerar situações de desemprego. Tais situações são vistas como experiências desmoralizadoras para os indivíduos que vinham projetando no trabalho suas esperanças para o futuro.

No processo de construir um projeto de vida, os indivíduos vão assumindo, ao longo de sua trajetória, uma multiplicidade de papéis, de acordo com as circunstâncias que vivenciam, as quais são incorporadas como parte de suas identidades e, desse modo, internalizadas e transportadas para os relacionamentos conjugais e familiares.

Assim, o trabalho torna-se parte da identidade individual, visto que representa uma grande parcela daquilo que os indivíduos fazem em seu cotidiano e de como definem a si mesmos; bem como, do modo como definem suas responsabilidades e deveres uns para com os outros no processo de viver e de construir seus projetos BUSCANDO O FUTURO SONHADO.

Entre o simbolismo construindo em torno do trabalho, como meio de viabilizar o projeto de vida individual e familiar, associam-se outros valores fundamentais como a dignidade, a liberdade, o respeito e a autonomia. 
Desse modo, o trabalho é o meio de viver com dignidade e vencer na vida por conta da própria força e sacrifício. O trabalho é o meio de ser valorizado e de obter respeito dentro da família, provendo o sustendo e a garantindo a satisfação das necessidades individuais e da unidade, e também fora do âmbito doméstico, uma vez que é o meio de adquirir representatividade social e diferenciar-se na comunidade em que vive.

O trabalho permite aos indivíduos e aos sistemas familiares construírem seus espaços de liberdade, representados pela possibilidade de escolha, de exercício da cidadania e de autonomia, visto que ele, o trabalho, proporciona o sonhar, o estabelecimento de projetos de vida e o senso de autodirecionamento em busca de realização.

Ao mesmo tempo em que viabiliza, a cada conquista, o trabalho também permite a satisfação de ver a concretização do projeto de vida, dos sonhos realizados, que envolvem o casamento, a casa e a criação dos filhos. Isso motiva continuidade BUSCANDO O FUTURO SONHADO em direção a busca de realização para novos sonhos, pautados nas necessidades concretas de existência e na crença de que de a vida familiar pode ser cada vez melhor.

A concretização do projeto de vida não depende apenas do trabalho, mas das expectativas e dos planos que são estabelecidos nas relações familiares, da expressividade do cuidado, das dificuldades que cada sistema familiar encontra em sua trajetória e do tempo que estão lutando, juntos, para construir seu projeto de vida. Desse modo, a própria ausência de realização dos sonhos e de concretização do projeto de vida que estabelecem é a motivação para a persistência BUSCANDO O FUTURO SONHADO. 


\section{A CASA}

No movimento BUSCANDO O FUTURO SONHADO, a casa é um sonho, uma aspiração, que acompanha o projeto de vida familiar. E, assim como o automóvel, se torna objeto imperativo e um dado da realidade vivida, que permite, aos indivíduos, a sensação de liberdade em seus movimentos e responderem às demandas de status social, internalizadas como parte do futuro sonhado, com o significado de vencer na vida.

Vencer ou fracassar na vida articula-se à casa, ao trabalho e ao conjunto de objetos adquiridos em sua materialidade e, em seu simbolismo, significa construir uma família e ser capaz de sustentá-la por meio do trabalho e do cuidado de modo a garantir o bem-estar, o fortalecimento individual e das relações familiares, no interior da casa, e em seu ambiente social mais amplo.

A natureza dinâmica do projeto se manifesta nas ações e interações familiares e, por sua vez, envolve o alinhamento de ações individuais. Desse modo, a construção de uma casa e de uma família, como um projeto de vida, envolve a negociação de expectativas e emoções, visto que cada indivíduo projeta no outro seu próprio futuro sonhado.

A depender do tempo que cada família vive, a casa e o casamento podem significar a concretização de um projeto, ou pode representar o inicio do projeto de vida familiar, ou a depender das circunstâncias vividas, podem constituir em si o próprio futuro sonhado. O projeto de construir uma casa e uma família pode vir acompanhado pelos planos e sonhos relacionados aos filhos, ou adquirir os meios de criar os filhos, constituem-se como meta estabelecida nas relações familiares.

Adquirir uma casa própria representa materialização de um projeto de vida construído em conjunto, enquanto que para outras famílias ainda é um sonho a ser realizado. Assim como o casamento pode ser a consolidação de um projeto, que foi cuidadosamente elaborado, pensando, decidido e vivido, ou pode ser a consequência de um acontecimento que leva à decisão de 
viverem juntos, como o nascimento de um filho. Bem como, ter filhos pode fazer parte do projeto de vida individual ou do casal, ou ambos serem acontecimentos, na vida, com os quais os pais têm que desenvolver meios para aprender a lidar.

Conforme os acontecimentos planejados ou inesperados e as dificuldades vividas, os projetos tendem a mudar como ações. No entanto, permanecem orientados à meta BUSCANDO O FUTURO SONHADO.

[...] "a gente (casal) planejava um monte de coisas, pensava em casar (oficialmente), mas isso tudo gasta dinheiro, a gente planejava um monte de coisas, comprar um carro" [...] (Mãe, família 6)

[...] "eu pensava que eu iria casar, que iria viajar para lá e para cá, que teria uma vida assim, iria ter uma filhinha, iria por ela na escolinha lá do hospital, que ia junto comigo, e mudou completamente os planos" [...] (Mãe, família 9)

Retoma-se a ideia de que cada família vive um tempo e uma circunstância em sua trajetória e que ambas influenciam a forma como o núcleo familiar é gerado e os projetos são estabelecidos, negociados, viabilizados no modo como seguem organizando o viver em função dos desafios que encontrados, das fragilidades vivenciadas, das forças forjadas e dos recursos que estão ao alcance.

Desse modo, os significados atribuídos para a casa e ao casamento, variam em função da história e das interações interpretadas e, sobretudo, relacionadas à maneira como organizam o viver no presente.

A casa, o casamento e a família, como símbolos associados entre si, permitem a individualização do núcleo familiar em relação às famílias de origem ou rede familiar ampliada. Atribuem a homens e mulheres um novo status e, com isso, deveres, obrigações e compromissos partilhados.

A casa, o casamento e os filhos podem representar conquistas na vida da família, que se configuram em marcos em sua trajetória ou podem representar intensos desafios a serem superados. 
Como espaço relacional, a casa é estruturada e significada pelas ações e interações familiares, ao mesmo tempo em que é estruturante e concretiza as relações familiares. Ligações estas, determinantes na dinâmica relacional do sistema familiar no âmbito privado e nas trocas que estabelece com o âmbito público.

Desse modo, assim como o trabalho, a casa e o casamento, integram a história e o universo simbólico do sistema familiar, dimensionam o tempo e o espaço familiar, e também determinam um destino comum aos indivíduos que se unem para viverem e construírem, juntos, seus projetos na trajetória BUSCANDO O FUTURO SONHADO.

A casa, mais que um espaço físico e relacional, carrega em seu simbolismo uma história, capaz de despertar fortes emoções. A casa assume diferentes representações na vida familiar, que variam em função do tempo e de como as ações e interações familiares ocorrem no interior ou em torno da casa.

A casa, para famílias que tem uma longa trajetória de vida construída em conjunto, representa a materialização de uma vida de trabalho e contém a história da família. Assim, casa, história e memória se fundem. Na história de vida, a conquista da casa e suas modificações, remetem às lembranças de acontecimentos significativos na vida familiar, como as transformações realizadas na casa para dar espaço aos novos integrantes da família, desempenhadas com zelo e esforço partilhado.

A casa, também pode conter a história transgeracional do sistema familiar, por ser uma a herança deixada pela família de origem, o que integra e acentua o compromisso com a preservação da casa/memória e com a continuidade da história familiar.

A casa traz o orgulho de ver um projeto realizado, representa a superação e a recompensa diante de um longo tempo de empenho e de luta BUSCANDO O FUTURO SONHADO. As melhoras na casa representam as 
melhoras na vida e proporcionam para a família continuar vivendo e sonhando com as possibilidades de melhorar seu viver cotidiano.

[...] "quando chegamos aqui, viemos morar dentro da casa da minha irmã, ficamos três anos morando na casa da minha irmã, a gente não tinha nada, aí conseguimos alugar aqui, hoje aqui (cidade) é bom" [...] (Mãe, Família 11)

[...] "antes, logo que a gente casou eu morava em dois comodozinhos lá no Nakamura, era nosso também, do meu marido também, né? Aí nossa eu falava 'Z. (marido) o U. (filho) vai crescer e não vai ter espaço para ele brincar nessa casa, dois cômodos só, isso e aquilo, será que um dia nós não vamos conseguir uma casa para ter o quarto dele?'... a firma mandou ele (esposo) embora depois de mais de 10 anos trabalhados na época, mandou ele embora, mas com o direito da firma, ele comprou aqui, né?... aí depois, de um ano e pouco que a gente estava aqui, conseguimos a reforma, o U. (filho) teve o quarto dele, né? o lugar é melhor, então a vida melhorou muito para a gente" [...] (Mãe, família 8)

[...] "graças a Deus a gente esta vivendo bem, está morando aqui, que a gente morava antes, antes sempre foi pior, a gente morava em uma casa que era ruim sabe?" [...] (Mãe, família 6)

[...] "eu sempre morei aqui, eu nasci e cresci aqui nesta casa... esta casa era dos meus pais e... depois que minha mãe faleceu, meu pai casou novamente e mudou com a esposa para Belo Horizonte, e eu e meu irmão, que é esse que mora aqui, que é solteiro, ficamos morando na casa que foi deles, depois eu casei e continuei morando aqui" [...] (Mãe, família 9)

A casa se torna o lugar de pertencimento da família e uma categoria moral e social. Ela ganha uma aura de uma entidade sagrada, um lugar dotado de valores incorporados como legados transmitidos ao longo das gerações, dotados de positividade e lugar de preservação e de transmissão da cultura familiar.

A casa torna-se um espaço de ação social e provê uma estrutura para a organização do sistema familiar em torno de deveres e obrigações mútuas, e para o desempenho de uma multiplicidade de papéis sociais (de homem e mulher, de pai e mãe, de esposa e de marido, de filho, de cuidador, de trabalhador, de chefe da família, de dona de casa entre outros) e para o desenvolvimento de relações complementares que delimitam subsistemas e os integram ao todo e ao meio em que vivem. 
[...] "eu sempre falo, 'aqui em casa eu não sou auxiliar, eu sou mãe', então para mim é tudo novidade, estou aprendendo agora, eu não sei nada" [...] (Mãe, família 9)

[...] "eu como o dono da casa, que sou o que falo mais mesmo (risos)" [...] (Pai, família 1)

A casa com seus objetos e símbolos impõem aos indivíduos que a habitam um conjunto de relações nas quais cada coisa e cada indivíduo ocupam um lugar simbolicamente atribuído, configurando o arranjo simbólico do sistema familiar, que permite aos indivíduos ordenarem o mundo social, mediante significado interacional. A espacialidade e temporalidade contida na casa atribuem sentido as ações e interações cotidianas. A casa se torna o espaço do costume e do ritual familiar.

A casa é o lugar do descanso, após uma longa jornada de trabalho. É - lugar de encontrar conforto por reunir a família, espaço de convívio, de diálogo, de partilha, de transmitir o que é certo, de orientar e encaminhar os filhos para a vida. É o lugar da vida familiar, da intimidade e da profundidade das relações. A casa e as relações que preserva representam proteção diante dos riscos ambientais ou sociais.

[...] "a gente prefere ficar os três juntos, ele (esposo) fala 'para eu ficar fora de casa já basta o trabalho que eu tenho que ir, saio duas horas de casa e chego meia noite e meia, quinze para a uma da manhã', ele (esposo) sai as duas horas da tarde, nós estamos na escola, eu chego três e meia, aí eu vou almoçar, porque eu não como na escola, aí tem dia que ele (filho) dorme cedo, eu procuro controlar quando eu posso, aí eu não deito, não durmo enquanto meu marido não chega [...] (Mãe, família 8)

[...] "aqui dentro é nosso, nossa casa, nosso espaço, sem outra pessoa, decidi que eu não quero outra pessoa na minha casa, quando em casa está bem, é fácil de educar, de você dar um alicerce para eles (filhos), porque quando está confuso, eles (filhos) não tem boas lembranças, não carregam boas coisas, quando está bem dentro de casa, eu consigo, dar atenção, sentar, conversar, dar carinho, ensinar o que é certo, porque acho que muitas coisas que eles (filhos) viram não era certo" [...] (Mãe, família 5)

[...] "nessa parte eu sou durão, ela (esposa) mesmo sabe que eu sou meio ignorante, assim nessa parte, o A. (filho) eu não solto ele com qualquer pessoa, primeiramente se chegar um amigo dele chamando ele aqui, eu 'digo não, é seu amigo?' é, faz favor entra aqui, onde você mora?, de onde você é? Quem é seu pai, sua 
mãe? você mora com seu pai, sua mãe? E não solto ele, não... 'hoje eu vou num baile, hoje a noite, mais fulano, fulano', eu 'digo não, não vai não, e acabou a conversa, vão vai mesmo!' Por que se eu não segurar ele, quem é que vai segurar? Hoje, em dia, se eu chegar a soltar ele ai na rua, só vão oferecer é...coisa...fazer coisa errada com ele...vão querer oferecer drogas, essas coisas, ainda mais na idade que ele está, 14 anos, então eu pego no pé mesmo, nessa parte eu sou, mas quando eu deixo também ele sair, digo, vai, mas é assim, assim e assim, tem horário para chegar" [...] (Pai, família 1)

A casa é um lugar em que deve ser cuidado e o ambiente no qual as formas de cuidar se expressam por meio das ações e interações familiares, desenvolvidas entre o casal, na criação dos filhos, entre os irmãos e no cuidado com as gerações anteriores.

A casa representa uma conquista fundamental do sujeito, como cidadão, o direito a morar, a ter privacidade e a ter seu próprio entorno social. Direito este conquistado com sacrifício, com o tempo e com o trabalho.

Em sua trajetória, é comum as famílias viverem um longo tempo em espaços de moradia partilhado com a família extensiva, mesmo após o casamento ou o nascimento dos filhos, até por meio do trabalho ou herança adquirirem seu próprio espaço de moradia. A casa fornece, então, as bases simbólicas para a continuidade do movimento de construção do projeto de vida familiar BUSCANDO O FUTURO SONHADO.

A casa, assim como o trabalho, configura-se como um espaço de liberdade e de autonomia. A ausência da conquista desse espaço e desse direito na vida dos indivíduos e na construção do projeto de vida familiar, pode representar privação e dependência, como formas de fragilidade, a depender de como os indivíduos seguem organizando o viver e BUSCANDO O FUTURO SONHADO.

A casa também pode ser o lugar do conflito, da ausência de diálogo e do desacordo, quando projetos e expectativas individuais não são correspondidos com o casamento e diante de uma série de sonhos não 
realizados, o que adiciona ao movimento BUSCANDO O FUTURO SONHADO a luta para preservar o casamento e continuidade unidade familiar.

[...] "quando eu comecei a me relacionar com o pai da E. (filha) eu nunca tive paz, daí para frente não tive paz, era muito ciumento. Eu trabalhava em um lugar público, mas tinha um vidro na minha frente, ele não via isso, era ciúmes demais, sabe?...então assim eu lutei tanto com ele (marido) no namoro, depois no casamento, na convivência a dois, depois lutei com ele na gravidez, lutei com ele no nascimento da E.(filha) e lutei com ele sabe?Sobrevivência. Sempre isso, isso mesmo, e agora eu não estou, estou fechando os olhos para muita coisa, estou fingindo que eu não estou vendo muita coisa, mais para quê? Para ter um pouquinho de união dentro de casa, para quê? Para não haver gritaria, para não haver xingação, para não haver nada, sabe? Só para ver se clareia um pouco a minha casa" [...] (Mãe, família 7 )

A ausência de condições adequadas de moradia também expõe 0 sistema familiar aos riscos secundários, a uma proteção precária e a estressores gerados pela dificuldade de acomodar as necessidades de conforto e de privacidade de todos os indivíduos que compõem a unidade. Assim, o movimento BUSCANDO O FUTURO SONHADO centra-se nos planos e nos meios para melhorar as condições do ambiente familiar.

Enquanto que a casa própria não se torna uma conquista, permanece sendo, ainda, projeto, sendo ainda o futuro sonhado. $O$ movimento BUSCANDO O FUTURO SONHADO para conquistar uma casa própria é interpretado como a possibilidade de aquisição de segurança social, diante da instabilidade de renda e de trabalho e, portanto, uma forma de reduzir a ameaça quanto a manter o local de moradia.

[...] "A gente fazia planos de comprar uma casa, comprar... nós estamos sem carro, a gente planejava comprar um carro" [...] (Pai, família 10)

[...] MÃE: "a gente pensava em fazer uma casa para não viver de aluguel, seria bom, né, para ter mais conforto para a gente, porque a gente paga aluguel, ao menos teria uma casa que seria mais..., teria um quartinho para ela (filha), então a gente não teria essa despesa... O PAI continua: é... eu tenho planos de aumentar o salário, tenho planos de conseguir assim as coisas, a gente queria construir aqui, só que é muito difícil, isso é um problema que a gente tem planos, mas não tem condições de realizar [...] (Família 11) 
A individualização do núcleo familiar, por meio de um espaço de moradia próprio, a depender das circunstâncias de vida, nem sempre ocorre de forma articulada ao casamento ou nascimento dos filhos. Algumas famílias iniciam sua trajetória e permanecem dividindo o espaço com parentes, de gerações anteriores ou da mesma geração. E enquanto a individualização do núcleo familiar não se tornar possível, também constitui um projeto de vida o ter-se um espaço próprio.

As rupturas que acompanham o desenvolvimento da família, no âmbito doméstico, a trajetória de ausência de paternidade partilhada, os rompimentos conjugais e a ausência de individualização do núcleo familiar, bem como, as dificuldades estruturais e relacionais que os sistemas familiares encontram para viver e construírem juntos um projeto de vida, são todos elementos de fragilidade experienciados pelo sistema familiar, na forma como vem organizando o viver e construindo uma história. Também podem gerar desesperança diante de um futuro sonhado que nunca se realiza.

O sistema familiar pode permanecer frágil ou fortalecer-se em função dos VÍNCULOS E APOIO SOCIAL que estabelecem como meios para viabilizar o projeto de vida ou fortalecer o cuidado nas relações familiares e manterem-se proativos BUSCANDO O FUTURO SONHADO.

\section{VÍNCULOS E APOIO SOCIAL}

A história dos vínculos revela aspectos da estrutura dos sistemas familiares e seus modos de organizar a vida cotidiana frente aos desafios que encontram em sua trajetória, das interpretações que realizam e das habilidades que desenvolvem em função de suas experiências de vida.

Assim, os vínculos estão articulados com o tempo, com as circunstâncias vividas e com o espaço relacional revelador, tanto das 
necessidades e desafios particulares, quanto das características de sociabilidade dos indivíduos e sistemas familiares.

Cada sistema familiar ao viver um tempo específico em sua trajetória, organiza o viver e cria um espaço relacional particular, com maior ou menor grau de individualização, permeabilidade e de vinculação com seu entorno social, o que, por sua vez, afeta a disponibilidade de apoio para a viabilização de seu projeto de vida BUSCANDO O FUTURO SONHADO.

Construir vínculos é uma habilidade que pode ser inata, como um traço individual ou aprendida e aperfeiçoada, conforme as circunstâncias e experiências sociais e culturais permitem. Construir vínculos duradouros e seguros, para alguns sistemas familiares, pode significar um intenso desafio. Desse modo, os vínculos podem indicar, tanto as forças, quanto as fragilidades estruturais e relacionais presentes no sistema familiar.

Sistemas familiares que trazem em sua história movimentos de migração social que, por sua vez, rompem com sua rede de vínculos significativos, são expostos ao risco de uma estrutura social fragilizada e desafiados a reparar as perdas sofridas pela migração, substituindo as funções dos vínculos rompidos.

Assim como a instabilidade de vínculos empregatícios e a instabilidade de vínculos conjugais podem expor a fragilidade, também podem revelar uma organização sistêmica de fortalecimento de vínculos com a rede familiar e social.

O sistema familiar é capaz de fortalecer-se em função de suas próprias vulnerabilidades vivenciadas. Desse modo, a organização do sistema familiar em torno de obrigações e deveres mútuos, expande os limites domésticos, integra a família extensiva e a comunidade, como espaços relacionais de apoio social. Esse tipo de organização integra a individualização e a interdependência de forma dinâmica, o que possibilita a ativação de sistemas de apoio social, diante das dificuldades vivenciadas. 
Entretanto, a inabilidade para construir vínculos, adicionada sobreposição de desafios cotidianos, pode ser representativa das principais fragilidades do sistema familiar.

A forma como o sistema familiar organiza o viver em função dos vínculos que estabelece, representa os meios que encontra para viabilizar seu projeto de vida e orientar-se na trajetória BUSCANDO O FUTURO SONHADO.

Assim como a casa, a comunidade provê uma estrutura para os relacionamentos familiares, enriquece 0 cotidiano e promove novas dimensões de ação e interação. A cultura familiar, como forma de comunicação estabelecida entre os indivíduos dentro do sistema familiar e com o mundo em que vivem, é uma herança simbolizada pelo conjunto de valores absorvidos das famílias de origem, mas também é um reaprendizado relacional, que se amplia nas interações e nas trocas de informação e comunicação com o meio social.

O sentimento de pertencimento ou não pertencimento à comunidade surge em função da história de como o sistema familiar interage e se integra com seu meio, do tempo, das características dos vínculos que estabelece e das formas comunicacionais desenvolvidas.

O sentimento de pertencimento e a integração com a comunidade tendem a ser mais forte nos sistemas familiares que se formaram e construíram uma vida em família e na comunidade e, desse modo, também tomaram parte da construção da comunidade em que vivem.

Os indivíduos e famílias migrantes que se inserem em uma comunidade com características socioculturais, por vezes, intensamente contrastantes daquelas contidas em seus ambientes de origem e, dada a ausência de referenciais simbólicos para a atuação, precisam desempenhar esforços adaptativos de forma a organizar o viver, integrando-se à comunidade e, ao mesmo tempo, mantendo a conexão com a rede familiar, preservando a identidade cultural e mantendo a continuidade da história. 
Nem sempre esse é um processo fácil ou possível na vida das famílias migrantes, pois muitas, ao migrarem, rompem de forma definitiva com suas famílias de origem e demais relacionamentos significativos ou vão perdendo o vinculo com a família, com a cultura e com a história conforme o tempo avança. Somado a isso, a inabilidade para reconstruir os vínculos, como forma de reparar as perdas e rupturas geradas pela migração e restaurar as funções de sua rede social de apoio, adicionam dificuldades estruturais e funcionais ao sistema familiar.

A integração dos migrantes à comunidade ou acolhimento dos migrantes pela comunidade, é facilitado quando migrantes de origem sóciogeográficas semelhantes ou familiares que migraram em tempos anteriores residem na comunidade e, desse modo, fornecem apoio para o migrante recém-chegado.

A identificação étnico-cultural que ocorre entre os indivíduos que vivem na comunidade permite a manutenção das tradições, hábitos e de costumes, como uma forma de reduzir os danos gerados pela migração, restabelecer os vínculos e o apoio social e ao mesmo tempo preservar a identidade cultural, como se estivessem reproduzindo o viver no novo ambiente sócio-geográfico.

As formas como os sistemas familiares se estruturam, por meio das interações simbólicas que estabelecem com a comunidade, permitem tanto a limitação, quanto a ampliação de seus espaços relacionais de ação e de participação social.

O sentimento de não pertencimento à comunidade, diante da inabilidade de construir vínculos ou hostilidade presente no ambiente, leva a uma limitação do espaço relacional do sistema familiar que é estruturado pelo trabalho e a casa, o que, a depender das circunstâncias e dificuldades vivenciadas, pode expor a fragilidade diante da escassez de recursos.

O sentimento de pertencimento à comunidade está fundamentado na habilidade de construir vínculos e nas características de sociabilidade dos 
indivíduos que compõe o sistema familiar. Tais habilidades expandem os limites delimitados pelo espaço da casa e configuram a rede de apoio social do sistema familiar. O sentimento de pertencimento à comunidade torna família e a comunidade sistemas interdependentes.

A interdependência está pautada na capacidade de cooperação em beneficio das necessidades individualizadas do sistema familiar, bem como, das necessidades apresentadas nos sistemas comunitários. Dessa maneira, os sistemas família e comunidade sentem-se responsáveis um pelo outro.

A identificação, a integração e a confiança que decorrem da interação estabelecida entre o sistema familiar e seu meio social permitem o desenvolvimento de um forte senso de conexão e de uma rede de solidariedade dentro da comunidade em que vivem. A casa e a rua se tornam complementares, ao mesmo tempo em que mantém seus limites simbólicos de diferenciação.

A ampliação do espaço relacional, por meio do desenvolvimento de vínculos fortes, representa os caminhos que possibilitam o suporte para 0 projeto de vida familiar, estabelecido em torno dos ideais de moradia, do trabalho, do casamento, da educação dos filhos e da convivência familiar e social, os quais caracterizam o desenvolvimento do sistema familiar ao longo do tempo BUSCANDO O FUTURO SONHADO.

Os vínculos iluminam as visões do futuro e mantêm os indivíduos proativos BUSCANDO O FUTURO SONHADO. Os vínculos têm o potencial de enriquecer a vida cotidiana, ao passo que adicionam emoção, entusiasmo e afetividade ao projeto de vida familiar.

O projeto de vida familiar acontece na comunidade e a família vai organizando o viver e segue construindo uma história em comunidade.

A vida familiar ocorre, sobretudo, no âmbito da casa e da comunidade. Como contexto de vida, a comunidade acomoda padrões educacionais, de trabalho e de renda. Essa particularidade da estrutura de 
vida dos indivíduos e sistemas familiares é delineada por um status sociocultural caracterizado pela baixa escolaridade, que molda os padrões de emprego, renda e visões de mundo; pelas condições de trabalho, como a instabilidade empregatícia, o estresse, baixos salários e escassos benefícios; a instabilidade ou restrição econômica, que determinam o estilo de vida, as opções de lazer e de acesso a bens e serviços sociais, entre os quais se destaca as condições e a insegurança associada à moradia.

A estrutura sociocultural dos sistemas familiares influencia a forma como organizam o viver e estabelecem seus projetos BUSCANDO O FUTURO SONHADO, a partir da realidade que a vida concreta oferece e de como ordenam e constroem seu mundo simbólico.

A estrutura social delimita certos padrões de comportamento e as interações dos indivíduos e do sistema familiar com a sociedade mais ampla. A vida da familiar e seus projetos ocorrem na comunidade, com maior ou menor grau de integração. É como se os sistemas familiares construíssem um mundo social à parte, que individualiza a vida na comunidade e a separa da sociedade mais ampla, o que faz que a vida familiar e social, assim como as continuas interações estabelecidas pelo sistema familiar se limitem à comunidade e à casa.

$\mathrm{Na}$ comunidade na qual vive, é que o sistema familiar se integra a outros sistemas, tais como, a igreja e a escola, e em geral, o próprio trabalho. É nessa comunidade que ocorre a vida social, representada pelo convívio, trabalho e lazer. De tal modo que o casamento entre pessoas que residem na mesma comunidade passa a ser comum, o que traz em si uma identificação por vezes étnica, cultural ou de classe social, ocorrendo, muitas vezes, casamentos entre parentes (primos de primeiro e segundo grau), especialmente entre migrantes, o que reforça a relação dos indivíduos migrantes com seu próprio grupo.

O lazer também ocorre predominantemente no âmbito da comunidade. As atividades de lazer tornam a vida mais alegre e mais leve diante da dureza do trabalho. Ele é o meio de manter o contato com a 
comunidade, com a família extensiva e de fortalecer os vínculos com aqueles que vivem a seu redor.

O lazer ocorre, predominantemente, nas reuniões com amigos, vizinhos e parentes, em festas e bailes comunitários e muitas vezes dentro da própria casa, entorno de almoços de domingo e das comemorações de datas especiais, como aniversários e feriados festivos. As viagens de final de ano são mais expressivas para os migrantes que veem nestas ocasiões uma oportunidade para manter a conexão com membros de suas famílias que residem em diferentes regiões geográficas.

[...] PAl: "A gente sempre teve muitos amigos mesmo que era do peito mesmo, do tempo que eu era solteiro tudo, que era da minha casa mesmo..." MÃE: "que eram daqui... que viviam aqui quando a gente não tinha a $L$ (filha doente) ainda, né? que a gente saía, quando convidava a gente ia passear, se divertir, fazia churrasco, era a casa cheia"... MÃE: eu gostava muito de sair (risos), gostava muito de sair, né? final de semana, passear um pouco, sair a noite, a gente sempre gostou muito de sair, ir em festas, sair os dois juntos (casal)... PAl: todo o final de ano a gente viajava para norte... [...] "na rua que a gente mora tem muita gente conhecida minha, da minha cidade lá, lá do norte, e da cidade dela (esposa) também, da Bahia, aí as pessoas se juntaram, e sempre um ajuda o outro quando precisa" (Família 1)

Assim, pertencendo e integrando-se à comunidade, o sistema familiar recria sua cultura e estrutura social, ao mesmo tempo em que a cultura partilhada mantém a comunidade. A realidade social torna-se um produto da interpretação que os indivíduos e os sistemas familiares fazem acerca de suas próprias necessidades e, desse modo, determina a forma como direcionam seus projetos de BUSCANDO O FUTURO SONHADO.

O sentimento de pertencimento, somado à forte integração entre o sistema familiar e a comunidade, permitem a construção de fortes vínculos de confiança e de afetividade. Os vínculos de confiança e de afetividade são evidenciados nas relações de cuidado que perpassam o sistema familiar e expandem os limites domésticos, especialmente no que se refere ao cuidado das crianças, que passa a ser uma função partilhada pelas mulheres que compõem a rede social familiar. 
A família é definida como aqueles com quem se pode confiar e contar com o apoio, especialmente nos momentos de dificuldade econômica ou na situação de doença. A família envolve além daqueles que vivem na mesma casa, a rede de parentes e de vizinhos que compõem a comunidade. Por mais difíceis que sejam as situações que perpassam a rede social, sempre há mobilização e cooperação em casos de necessidade, constituindo-se em uma fonte primária e constante de apoio.

[...] "os vizinhos gostam muito de mim, vem aqui sempre que podem vir, perguntam se eu estou precisando de alguma coisa, você vê, que eles vem, me ajudam. Assim, eu nasci e cresci aqui então todo mundo gosta muito de mim" [...] (Mãe, família 3)

[...] "eu não tenho apego de família, não tenho ninguém, sabe?, não tenho ajuda de ninguém, nem do meu marido que vive comigo... a gente precisa de apoio pra tudo nessa vida, e eu me sinto como um carro sem óleo, que não vai para frente, porque eu não tenho o apoio de ninguém, nunca tive" [...] (Mãe, família 7)

O sentimento de independência econômica e emocional entre os indivíduos em relação à própria família e à comunidade leva-os a projetarem no trabalho todos os seus esforços e vê-lo como o único meio para a realização de seu projeto de vida.

A carência de vínculos seja pela ausência de familiares geograficamente próximos, seja pela ausência de afetividade que resulta na não incorporação dos vínculos com as famílias de origem pelo casal, leva a uma vivência de desapego ou desamor nas relações familiares e, por sua vez, conduz à carência de apoio social diante das dificuldades. A carência de vínculos afetivos pode conduzir a sentimentos e ações desagregadoras e os vínculos frágeis tendem a ser rompidos diante de uma situação na qual se sentem ameaçados, inseguros ou que acarreta a impotência diante de um desafio que excede seus próprios recursos.

Assim, o sistema familiar pode fortalecer-se em razão de suas próprias fragilidades, graças à sociabilidade e aos vínculos desenvolvidos em seu espaço de pertencimento, seja no âmbito da vida privada, mantendo a coesão interna do sistema familiar, como no âmbito da vida pública, na 
comunidade e no trabalho, mantendo a conexão e a interdependência como meios de viabilizar o projeto de vida.

De acordo com tais características, é possível dizer que a família pode ter uma estrutura fragilizada, pela fragilidade dos vínculos e de apoio social. A estrutura social fragilizada reflete a fragilidade dos indivíduos que compõem a família e se manifesta nas ações e interações familiares, nos projetos que estabelecem e nas dificuldades que encontram para viabilizá-lo.

A estrutura social revela a forma como a família interage com seu ambiente. Embora o contexto molde padrões educacionais, de trabalho e de renda, é possível perceber que organização familiar pode transformar a estrutura social pelo fortalecimento de vínculos internos entre o casal e entre pais e filhos e sustentação e ampliação de vínculos com sua rede social de apoio, representada pela rede de parentesco, de amizade e de vizinhança, o que permite a forte conexão e cooperação, alinhamento de forças, recursos e papéis sociais para o enfrentamento dos problemas cotidianos e alcance de metas comuns à unidade familiar.

A ampliação do espaço relacional e o fortalecimento dos vínculos internos e com a comunidade amplia e fortalece o apoio social permite ao sistema familiar flexibilidade e adaptabilidade frente aos desafios sociais, permite ainda aos indivíduos sentirem-se protegidos e seguros na casa e na comunidade em que vivem e, desse modo, alcançarem bem-estar em seu próprio ambiente.

A ampliação da rede de relacionamentos do sistema familiar, que integra indivíduos de diferentes gerações, que integra religião e trabalho, que integra indivíduos de diferentes status sociais, amplia a cultura familiar e as visões dos indivíduos sobre os desafios cotidianos, capacitando-os para tomadas de decisões e aumentando suas habilidades de resolução dos problemas.

As formas como os sistemas organizam a vida diária refletem padrões de comportamento, que evidenciam maior ou menor grau de coesão interna 
e de conexão com o meio social, de flexibilidade ou de rigidez, que podem ser barreiras ou facilitadores, quando padrões adaptativos são exigidos diante de uma transformação definitiva nas circunstâncias de vida.

Estas particularidades constituintes da vida familiar influenciam a forma como o sistema familiar interage entre si e com o ambiente em que vive, com o cuidado de saúde, bem como os significados atribuídos aos eventos de seu ciclo de vida, que podem impedir ou facilitar a vivência do tempo da doença na trajetória de vida familiar.

\section{VIVENDO O TEMPO DA DOENÇA}

Ao confrontar-se com a situação de doença grave da criança, cada sistema vinha construindo seu projeto de vida familiar em BUSCA DO FUTURO SONHADO, vivendo um tempo específico em sua trajetória, organizando o viver e construindo uma história de acordo com as circunstâncias, os desafios vivenciados e os meios que a vida concreta thes oferece.

O tempo familiar influencia o movimento empreendido para a realização dos sonhos. Desse modo, o tempo tornarem-se pais, está relacionado ao sonho e as expectativas projetadas em relação ao filho. $\mathrm{O}$ tempo de unirem-se sobre a mesma casa está relacionado ao sonho de construir um casamento e uma família próspera, ou ao tempo de lutar pela promoção do casamento, dos filhos e da unidade familiar.

Assim, como os tempos de trabalho e de desemprego, os tempos de coesão e de fragmentação, os tempos de saúde e de doença também descontinuam e transformam o viver, os projetos e expectativas para 0 futuro.

Desse modo, cada indivíduo e sistema familiar, ao terem suas vidas tomadas pela situação de doença da criança, vivenciava um tempo específico em sua trajetória, dimensionado em função dos acontecimentos, 
pelas interações interpretadas e conjunturas construídas pelo contexto social, que acompanham a existência de cada grupo familiar. Tempos estes, de menores ou maiores lutas e sacrifícios empreendidos na busca do futuro sonhado, em função dos desafios e dificuldades que vinham enfrentando no movimento de construção do projeto de vida.

O tempo familiar vivenciado releva forças, fragilidades e riscos, que influenciam a forma como interpretam, absorvem e lidam com os desafios trazidos pelo tempo da doença que, por sua vez, é ameaçador e transformador das circunstâncias de vida familiar.

Assim, vivendo o tempo da doença refere-se ao recorte temporal da experiência da família, que simboliza a ruptura que a doença provoca entre a história construída e a trajetória de vida familiar, que passa a ser dimensionada pelo tempo da doença.

\subsection{COMPREENDENDO A EXPERIÊNCIA DA FAMILIA}

\section{TENDO O PROJETO DE VIDA FAMILIAR AMEAÇADO}

Na vida familiar, a incidência de uma doença grave e limitadora, tanto das condições, quanto do tempo de vida da criança, é interpretada como uma situação psicossocial potencialmente devastadora, definida como TENDO O PROJETO DE VIDA FAMILIAR AMEAÇADO, devido à percepção concreta dos riscos e da probabilidade de provocar mudanças e danos irreversíveis à vida individual e familiar.

A informação de que o tempo de vida da criança está delimitado em função do diagnóstico, bem como, suas condições de sobrevivência são incertas e condicionadas à tecnologia de suporte à vida, gera uma ruptura na trajetória e no sistema de significados que integravam o universo simbólico 
familiar, diante da percepção de perda de controle sobre o curso da vida familiar, da ausência de garantias para o futuro e da necessidade de se definir uma nova realidade de vida familiar.

Estar sob o impacto da situação de doença da criança, nessas circunstâncias especificas, é simbolizado pelos indivíduos como se estivessem vivendo um desastre na vida familiar, diante da desintegração que provoca entre a história familiar construída e a identidade social dos indivíduos e o futuro sonhado.

O impacto com a condição de vida da criança e da família é visto como sendo algo inaceitável e isso deixa os indivíduos sem rumo diante da ausência de garantias quanto ao futuro.

A família passa a ter de lidar com o caráter definitivo de sua nova condição de vida e com a ausência de garantias para o futuro, com a incerteza quanto ao tempo que irá viver essa condição, o que poderá ser por dias, meses ou anos, e nem os rumos que o sistema familiar seguirá diante da percepção TENDO O PROJETO DE VIDA FAMILIAR AMEAÇADO.

[...] PAI: É... a gente fica... a gente ficou tanto tempo sem vir a $L$. (filha), né? assim a gente esperando, o A. (filho) já grande, depois não, vamos ter mais um filho, e quando vem, aí vem como uma síndrome dessas... aí quando chega, a gente tem que cuidar do $\mathrm{A}$. (filho) tudo, a gente fica com o estado emocional meio abalado, a gente fica, não só a gente, como ele (filho) ficou também. O A. (filho) ficou... precisou passar em psicólogo, o A. (filho) ficou assim que ... quase que adoecido mesmo com a gente aqui... o A. (filho) ficou assim... quase que meio perturbado sabe? A gente já estava com o problema da L. (filha), e tinha que segurar mais o dele (filho) ainda... quando ele viu o desespero da gente, quando a gente soube da doença que ela tinha né? a gente chamou ele (filho) e conversou né? porque eu não ia negar, eu disse não, tem que preparar ele (filho) junto com a gente... MÃ̃ continua: Ah! É difícil né? você reage assim... é um impacto que você fica desorientada! Pensando meu Deus, você ter uma filhinha depois de tanto tempo, e nasce com uma doença que os médicos falam que não tem cura, né? e como a médica das clínicas falou, quem tem essa síndrome geralmente vive só até um ano e meio, aí... chegava aquela fase ali, eu ficava desesperada, aí meu Deus, chegou um ano e meio, é hoje...é amanhã, você vive sabe... num sofrimento né? porque é muito difícil, você fica sem saber o que vai acontecer... seu emocional assim... mexe muito...na sua cabeça assim... você fica contado... ah é hoje, amanhã, porque os médicos falam isso, falam aquilo, que vai acontecer o pior... e que...é desesperador...[...] (Família 1) 
A condição de viver com uma criança com necessidades especiais de cuidado de saúde surge com o nascimento da criança, apresenta-se como um desafio adicional na vida dos indivíduos e dos sistemas familiares, o qual irá fazer parte de suas vidas de forma constante e definitiva.

O confronto com a condição de vida da criança e da família expõe a fragilidade individual e sistêmica da família, diante da percepção TENDO O PROJETO DE VIDA FAMILIAR AMEAÇADO, e, ao ser exposta, os vínculos são colocados sob a ameaça de rupturas definitivas, por conta da fragmentação que a hospitalização prolongada gera na vida familiar. $O$ trabalho é posto em risco e os valores fundamentais que atribuíam sentido à vida familiar são confrontados e as crenças parentais são desafiadas.

[...] MÃE: "no começo para mim... eu achava que ela (filha) iria morrer, porque a primeira vez que eu fui ver, ela (filha) estava muito ruinzinha, ela estava toda intubada, ela era muito pequenininha, aí a gente chegou de tarde... tinha dia que a gente chegava lá, aí o médico falava assim 'olha a gente teve que colocar mais uma droga para ver se ela (filha) fica viva, e... não sei se vocês vão chegar aqui amanhã e ela vai estar'... PAI continua: "Foi bem complicado, eu falo para você... não foi fácil. Até porque eu trabalhava, ela (mãe) trabalhava, a gente tinha o Y. (filho) pequeno, aí de repente surgiu a M. (filha doente) e... foi complicado... para a gente, para a família mesmo, né?, ficou todo mundo meio... sabe? No começo a gente ficou meio... assim... só nós mesmo, porque o pessoal (familiares) não... só falava muito e fazia pouco, e... eu não gostava de... na verdade eu não gostava nem que fossem visitar ela (filha), então, tinha muita gente que ia lá e falava assim 'ah ela não vai conseguir, ela não vai sobreviver, ah... ela vai ficar com defeito', sabe? Aquelas coisas, aquelas conversas que... sei lá... nada a ver!...ai... você entendeu? você está desabituado, você está com um problema para o resto da vida...e se é uma pessoa para ir lá e dar uma força, falar um negócio legal, 'nossa, tenha força' sei lá, ah... 'tenha fé em Deus que ela vai sair dessa', entendeu?, mas meu... ninguém! ... todo mundo que ia lá, botava a gente bem para baixo assim... e... eu preferia que não fosse mesmo... era só a gente mesmo indo lá ver ela e fomos dando força para ela (filha), depois... os médicos falaram que já podia pegar ela (filha) da incubadora, ficar com ela (filha) no colo e ela (filha) se sentia bem...[...] (Família 3).

A incidência da doença desorganiza o espaço relacional do sistema familiar, tanto no âmbito privado, diante da necessidade de convívio com a incerteza e hospitalização prolongada, quanto no âmbito público, afetando o apoio disponível e colocando o sistema familiar em contato com sistemas 
sociais e de cuidado de saúde, com objetos e símbolos que antes não integravam o universo familiar.

A percepção de TENDO O PROJETO DE VIDA FAMILIAR AMEAÇADO diante da vivência de um desastre assume um significado de perda simbólica do futuro sonhado.

[...] "Eu não aceitei. Não. A Dra. L. chegou para mim, por sinal, muito educada para falar as coisas, até então, ela (médica) veio falar para mim que a E. (filha), tinha Síndrome de West, que era um atraso neurológico, que ela não iria ser uma criança normal, e eu não aceitei, eu não aceitei nada, eu falei 'poxa não é, não é, minha filha não é especial', cheguei em casa nervosa e falei 'R. (pai) minha filha tem uma síndrome, minha filha não vai falar, minha filha não vai andar, minha filha vai vegetar', ai foi quando ele (pai) ficou meio abalado também, porque assim... era o sonho dele... acho que o susto maior foi esse, era de ser pai, mas eu não pude dar essa criança para ele, que ele queria, uma criança normal como os sobrinhos dele que são normais, ai ele (pai) começou a falar 'ai fulano minha filha é especial, não sei o que, minha vida desgraçada'... e eu comecei a brigar com ele (pai), a gente tinha brigas seriíssimas porque eu não aceitava que a minha filha era especial, tantas vezes briguei com meu irmão, meu cunhado porque assim eles falavam que a minha filha era especial, e eu 'não minha filha não é especial' [...] (Mãe, família 7).

Ao se dar conta do caráter definitivo da condição de vida, os indivíduos se percebem perdendo o futuro sonhado. A história construída e o projeto que atribuía sentido e aportava à vida familiar passam a ficar distantes, localizados em um tempo passado que dificilmente poderá ser recuperado e que é gradualmente interrompido, consumido ou transformado pelos acontecimentos que acompanham a evolução da doença da criança e, com ela, as novas demandas da vida concreta.

A trajetória de vida é alterada de forma definitiva, devido às fragmentações e descontinuidades que a condição de vida da criança e a dependência tecnológica provocam no sistema familiar.

As ações e interações familiares são modificadas em função dos eventos, das limitações e das necessidades complexas de cuidado que acompanham a condição de vida da criança e a percepção de ameaça ao projeto de vida familiar pode ser potencializada pelo risco de não 
conseguirem manter a coesão interna do sistema e a conexão com a rede social, diante de um tempo de hospitalização.

\section{Ao perceberem-se TENDO O PROJETO DE VIDA FAMILIAR} AMEAÇADO, os indivíduos que integram o sistema familiar passam a viver diferentes níveis de desespero, desamparo, insegurança, desconfiança, incerteza e sofrimento, diante da perda simbólica do futuro sonhado.

Os riscos e os desafios são potencializados, como elementos dinâmicos e presentes na vida familiar. As competências familiares são ameaçadas diante da condição e das necessidades de cuidado da criança, bem como, do senso de capacidade para lidar com a situação no contexto de vida familiar.

A confrontação com a doença da criança, dada suas características de gravidade, de dependência tecnológica, de incurabilidade e de incerteza quanto ao tempo de vida, desestrutura o tempo e o espaço da família. É como se estivessem vivendo em outro mundo.

[...] Assim que eu soube, assim que nasceu eu já percebi que tinha alguma coisa estranha, o diagnóstico veio depois de três meses, mas foi horrível parecia que.. ah eu nem sei explicar porque era muito difícil sabe? Muito pesado para imaginar como seria a minha vida, de imaginar a realidade... isso da A. (filha) quando a A. (filha) nasceu, daí eu tive que me acostumar na marra sabe? Eu falava: 'eu não aguento', mais eu tinha que aguentar... foi muito difícil porque foi o impacto assim, coisa que eu nunca tinha visto na minha vida, nunca imaginava que existia essas doenças assim, ai eu dei de cara com tudo aquilo porque eu nunca tinha visto, além de Síndrome de Down eu nunca tinha visto outra doença na minha vida, sabe dessas igual que a A. (filha) tem que a L. (criança de outra família) tem. Nunca tinha visto, era... parecia que era outro mundo, e é mesmo outro mundo sabe? Tudo muda, muda do começo ao fim da sua vida, muda tudo [...] (Mãe, família 6)

O tempo familiar passa a ser dimensionado em função da doença e dos acontecimentos que acompanham sua evolução e, desse modo, os indivíduos que compõem o sistema familiar se percebem submetendo-se ao o tempo da doença. 
Ao submeter-se o tempo da doença e, dessa maneira, decidir viver o tempo entre a vida e a morte da criança, a vida familiar passa a ser controlada pela trajetória da doença.

Ainda que a situação se apresente como ameaçadora e conflituosa, frente à ruptura que provoca na trajetória de vida e dos sistemas de significados, os indivíduos que compõem o sistema familiar, especialmente os pais, fazem indicações para si mesmos de que precisam agir, no tempo e com os recursos que dispõem, no sentido encarar a realidade e a missão de preservar a vida da criança.

[...] PAl: conforme... a gente foi, a gente já foi pegando os obstáculos logo no começo, por que tanta pressão, tanto isso, tanto aquilo né?, aí... a gente acabou até se acostumando, de certa forma, se adaptando a isso, mas nunca....abandonar nunca (mãe concordando) MÃE: (completa) que os pais abandonam né? PAl: se ela (filha) ficasse lá no hospital um ano ou a vida inteira, se não tivesse como trazer para casa, mesmo, a gente iria ficar lá do mesmo jeito. Já a gente, a prioridade era essa, o tempo que fosse seria desse jeito, o sistema seria esse, ela (esposa) ficava a semana, eu ia três vezes por semana, ela (esposa) vinha no final de semana, e determinadamente iria ser isso... até o fim da vida! Então, como a gente já havia colocado isso como um parâmetro único, então a gente foi se acostumando...sempre nesse ritmo[...] (Família 4)

A vida da criança não se apresenta como uma opção para os pais, que assumem para si o dever de cuidar e manter a vida do filho, independente de quais sejam as condições, tanto da criança, quanto da família, além das consequências que possam gerar para a vida familiar. Diante dessa concepção moral, os pais tornam-se decididos a investir em seus esforços e nos recursos de suporte tecnológico, de forma a prolongar a vida da criança.

Submeter-se ao tempo da doença é definido como o tempo entre o diagnóstico e a morte da criança e faz que determinados indivíduos ou grupos, suspendam a própria vida e a vida familiar para estar junto da criança, o que provoca um desajuste em relação aos outros tempos e demandas familiares e, por vezes, implica em viver entre o futuro sonhado e a nova realidade de vida familiar, que precisa ser assimilada. 
Os indivíduos e sistemas familiares que vinham, em sua trajetória, construindo seu projeto de vida familiar, organizando o viver e construindo uma história, em um movimento de busca pelo futuro sonhado, ao terem suas trajetórias modificadas pela circunstância de vida gerada pela doença, precisam reinterpretar suas lutas e seus sacrifícios, suas crenças, seus deveres e obrigações mútuas, considerando o passado e o futuro, antes, tido como garantido e submeterem-se ao presente.

Submeter-se ao presente é definido como o tempo da doença, demanda uma reorganização do sistema familiar e traz, em si, o desafio da aceitação de renúncias e de restrições, assim como da incorporação de novos sacrifícios à vida familiar.

Mesmo diante de uma situação que se configura como ameaçadora e inaceitável, os indivíduos e grupos familiares, ao submeterem-se ao tempo da doença e, de certo modo, deixarem-se conduzir pelos eventos que acompanham a trajetória da doença, com o tempo vão assimilando a condição de vida da criança e da família; o que, por sua vez, pode tanto potencializar o sentimento de ameaça, quanto mobilizar o desenvolvimento de forças, a depender de como as definições são construídas e partilhadas e, de como o sistema familiar se organiza para lidar com a situação.

\section{ASSIMILANDO A CONDIÇÃO DE VIDA}

Conforme o tempo da doença é vivenciado, os indivíduos e sistemas familiares vão assimilando a condição de vida da criança e da família.

A assimilação da condição de vida da criança e da família representa um processo cognitivo contínuo na experiência da família, que pode ser promovido nos encontros com profissionais de saúde e com outras famílias de crianças com necessidades especiais de cuidado, tanto durante a hospitalização da criança, quanto ao longo do cuidado domiciliar. Entretanto, além da forma como a família vivencia as interações com outros sistemas de 
cuidado, profissionais e leigos, interpretações resultantes das interações que ocorrem no interior dos indivíduos e daquelas que são partilhadas na totalidade dos relacionamentos familiares são determinantes sobre a forma como a condição de vida é assimilada e, por sua vez, vivida.

Desse modo, a assimilação da condição de vida da criança e de vida familiar tem o potencial, tanto para amenizar, quanto para potencializar os conflitos entre a perda do futuro sonhado e a circunstância de vida gerada pela condição de dependência e das necessidades especiais de cuidado da criança. O que, por conseguinte, influencia no comprometimento do sistema familiar, diante da percepção de capacidade ou de incapacidade para lidar com a situação.

A doença da criança e a dependência tecnológica, como meio de manter a vida, introduzem tensões e ambiguidades ao universo simbólico familiar, diante da ruptura que provoca entre escolha e destino, entre a vida constituída, segundo as leis da natureza, e a vida que a tecnologia produz. Por meio da tecnologia de suporte de vida, o sistema familiar absorve símbolos que são mediados pela força do imaginário sociocultural e que, por sua vez, devem ser interpretados e assimilados pelo sistema familiar.

Desse modo, no processo de assimilação, os esforços são direcionados tanto à irem assimilando a condição da criança, que envolve a aceitação e a internalização, quanto parte do papel e da identidade parental; à assimilando a cultura técnica do cuidado envolve um processo de socialização para a construção e o desempenho dos papéis parentais de cuidadores de uma criança com necessidades especiais de saúde; e o processo de elaborando as possibilidades de vida é direcionado à assimilação da complexidade desse evento na vida familiar, o que, por sua vez, os remete aos meios que encontram para inserir o cuidado da criança à vida e ao ambiente familiar.

Assim, ao irem assimilando a condicão da criança, os indivíduos que compõem o sistema familiar são confrontados com os dilemas de aceitação das limitações de vida e da dependência tecnológica da criança. Muitas 
famílias se veem confrontadas com a aceitação da necessidade de a criança viver no hospital, diante de uma situação que excede os recursos familiares para cuidar da criança em casa. Especialmente os pais, se percebem sendo desafiados em suas crenças.

A aceitação da condição de vida da criança apresenta-se como um desafio para os pais, demanda ajustamentos cognitivos e nem sempre é internalizada como parte da construção de suas identidades. Os pais podem ter dificuldade em reconstruir suas crenças e em assimilar essa condição circunstancial de paternidade, o que pode implicar em constantes tensões e conflitos internos e na vida familiar, ao sentirem-se incapazes de aceitar a condição de vida da criança e da própria condição de serem pais.

A dificuldade em aceitar a condição de vida da criança pode gerar barreiras cognitivas que conduzem aos desajustes constantes, entre a realidade de vida da criança e as projeções dos pais e, por sua vez, dificultam a vida familiar.

Desse modo, a forma como os pais interpretam a condição da criança influencia suas decisões e ações ao longo da experiência. Enquanto a decisão de preservar a vida da criança apresenta-se como algo inquestionável para os pais, as projeções e ações estabelecidas variam em função de suas crenças.

[...] MÃE: "eu penso que você tem que aceitar, a partir do momento que você aceitar, se Deus lhe deu essa missão é para você aceitar, aceita, vai cuidando, vai vivendo o dia-a-dia, amanhã não sei o que vai acontecer, né? [...] eu sempre estou conversando com outras mães... isso ajuda porque num momento você acha que só você tem aquele problema, você fala: nossa! mas isso aqui acontece só comigo? Então... eu fiquei cinco meses no hospital e fui aprendendo, não é só com a gente que acontece... PAl continua: igual... as outras crianças chegavam na UTI, chegavam hoje, quando era amanhã já...já falecia né? e aqueles pais dentro daquele quartinho com a gente ali, né? aí eu falava para a Neuza, olha a gente tem que dar graças à Deus porque nossa filha está é viva, imagina se a gente estivesse passando o mesmo que esses pais aí, né? [...] (Família 1).

[...] "Ah, eu tento relevar, não que eu aceite, sabe? Eu sei que tem, mas não é que eu aceite que ela (filha) tenha isso, eu não aceito, para falar a verdade...assim, eu não aceito. Quando eles (profissionais) comentam tudo ou quando entrou em óbito alguma 
criança assim lá (no hospital), eles (profissionais) falam ah 'S. é tão ruim ter que passar por isso' tipo assim, que eu vou passar, eles querem dizer, e eu não aceito isso, eu não aceito ter que passar por isso, sabe? Ah, é muito difícil isso na minha cabeça, muito difícil! Tanto que quando ela interna assim, eu não quero sair de perto, sabe? Ah, não sei, não sei se eu tenho muito medo de perder, se eu não sei o que acontece assim comigo (debruçase sobre a cama, de frente para mim para falar e chora) porque eu sinto assim muito, eu me apeguei muito assim com a S., devido ao sofrimento que ela teve lá (na UTI), por que ela lutou muito para viver, a S. teve três paradas! Ela lutou muito! $\mathrm{E}$ eu sempre pedia, sabe? e pedi muito para ela (filha), assim ' $\mathrm{S}$. eu sei que você está escutando a mãe e a mãe te pede pelo amor de Deus para você não morrer, a mãe quer cuidar de você, a mãe te ama do jeito que você é e eu vou cuidar de você', sabe? Conversando com ela, mesmo sabendo que ela não estava ali escutando, mas eu também não sei se ela não estava escutando né? Mas eu falava para ela, fala assim: 'volta filha! Por favor, a mamãe te ama, a mamãe quer cuidar de você, eu vou cuidar de você direitinho, a mãe nunca vai te deixar', sabe? Eu falava um monte de coisa para ela, sabe, e ela voltou, na ultima tentativa deles (médicos) ela voltou. Aí, eu não sei, eu tenho muito medo de perder a S., muito medo, eu não sei assim se eu vou aguentar (chora novamente $e$ começa a falar com dificuldade)[...] (Mãe, família 3)

As crenças parentais também são desafiadas ou ampliadas nos encontros com os profissionais de saúde. Os pais se veem desafiados em suas crenças, especialmente quanto se veem sendo pressionados a aceitar a verdade médica, no que diz respeito ao prognóstico da criança e ao contínuo investimento em tecnologia de suporte de vida. Os pais se recusam a aceitar a verdade médica como única, diante da necessidade de manterem um sentido para suas ações e seus valores associados à preservação da vida da criança. Desse modo, os pais passam a ver a perda da criança como um risco e não como algo concreto, "fechado", em função de um tempo prédeterminado.

As crenças parentais, por outro lado, também podem ser ampliadas nos encontros com os profissionais e famílias que vivem situações semelhantes, especialmente, quando os pais acreditam que não são capazes de suportar o sofrimento.

[...] "Essa é a pressão que eu falo que foi colocada, foi isso, né?, porque enquanto tiver uma esperança é uma coisa, mas quando já chegam na sua cara e falam 'oh, ela esta indo para lá (hospital), mas praticamente vai, mas não volta', né? 'vai, mas não volta', 'vai e vai ficar lá, o resto da vida, precisando de um aparelho para 
respirar, por que se tirar esse parelho ela morre na hora, não pode nem ficar meio segundo sem o aparelho que para ela já... já pode ter uma parada respiratória e tudo, né?'. A pressão maior, no inicio, foi essa! Ela (esposa) até chorou na sala, os médicos acharam até que eu fui meio 'Robert', por que tudo que eles me falaram... o que eles me falaram era uma coisa, mas na minha cabeça era outra, por que eles podiam falar que ela ia 'coisar' e... que para mim nada daquilo ali, enquanto não acontecia era real, por que eu já tenho isso de mim, eu só acredito no que acontece, o que está para vir ninguém sabe, porque hoje a gente está bem e amanhã pode estar ruim, mas do mesmo jeito a gente pode estar ruim hoje e amanhã estar bem, então... o que eu acho que a pressão maior foi essa... um dia lá o médico também falou, mais falou para ela (esposa) do que para mim, por que ela (esposa) começou a chorar ali, e eu nem... nem me... tipo... igual como eu estava lá... igual... como eu entrei eu sai, por que eu não posso ficar me abalando na frente dela (esposa), por que eu sou o apoio dela (esposa), né?, ela (esposa) é a parte sensível e eu sou a parte forte, se a parte forte cair, então, dessa parte sensível o quê resta? Nada né? [...] (Pai, família 4)

[...] A S.(outra mãe) me ajudou... exatamente..., porque você já percebeu que ela (outra mãe) tem um jeito calmo de contar?, ela chegou em mim e contou assim 'você vai conseguir porque eu estou conseguindo, a A (filha) nunca falou, nunca andou, mas a L. andava, a L. falava, e agora olha como que ela está'... e sabe? eu olhei assim, eu vi aquela coisa de que...ela (outra mãe) estava ali, ela estava bem, ela não estava chorando, ela (outra mãe) não tinha morrido, então isso para mim já foi o suficiente, para eu ver que iria aguentar! E também eu conheci um médico assim, que para mim ele (médico) foi a parte da fé assim... e chegou para mim e falou ' $C$., você não deve acreditar só em tudo que os médicos falam, porque as vezes eles (médicos) falam coisas que eles acham que vai acontecer, mais só quem sabe o que vai acontecer é Deus, não estou falando que os médicos não sabem, mas que nem tudo que os médicos falam acontece...' foi um médico que conversou muito... ele falava: 'você tem que pensar que não é só aqui, você tem que pensar que existe muito mais coisa, entre o céu e a terra, existe Deus, não é só os médicos que existem, eles sabem de muita coisa, a gente sabe de muita coisa, mas não sabe tudo'... aí foi todas essas coisas sabe? Assim da S. (outra mãe) eu consegui ver essa outra parte de falar 'eu vou conseguir', sabe? [...] (Mãe, família 7)

A condição da criança, a gravidade e instabilidade clínica, adicionada à dependência tecnológica, também desafiam a crença dos pais, quanto à capacidade de proverem o complexo cuidado que a criança precisa. Os pais se percebem sentindo-se ameaçados em suas competências, diante de uma situação que excede a capacidade de compreensão, suas habilidades e os recursos disponíveis para prover o cuidado e preservar a vida da criança em seu próprio ambiente familiar. 
Entretanto, diante do sentimento de ameaça às competências, a atitude tendo disposição para aprender, adicionada à concepção dos pais que devem ser constantes na vida da criança, pelo tempo que for possível, aproxima o sistema familiar ou determinados indivíduos de outros sistemas de cuidado de saúde, como forma de encontrar os meios para capacitaremse, para prover o cuidado e, desse modo, irem assimilado e adquirindo o senso de controle sobre a vida da criança e sobre a vida familiar.

[...] "Quando a gente chega, no começo a gente não sabe de nada, você não sabe o que está fazendo com seu filho, se vai ser bom ou se não vai... e a gente fica assim meio... eu aprendi, porque eu aprendi a perguntar tudo para o médico, então com aquelas dúvidas minhas, eu fui perguntando e aprendendo, hoje eu cuido dela mais fácil, porque quando a gente vê que é assim mesmo, eu não sabia o que era nada disso... esse tipo de coisa, esses aparelhos, a gente nunca tinha visto, nunca tinha convivido com isso e na nossa casa, para a gente 'labutar' com aquilo, mexer com o aparelho... primeiro era eu, depois eu ligava para ele (esposo), se o médico me falava, alguma coisa nova" [...] (Mãe, família 11)

[...] "Você nunca imagina, você numa situação daquelas, daí quando você está, você... eu achava que eu nunca iria conseguir cuidar da S. (filha), e nisso eu sofria muito, por que eu não aceitava que ela ficasse no hospital e ter que as outras pessoas cuidar dela, e não eu que era a mãe dela, entendeu? [...] (Mãe, família 3)

Desse modo, a doença da criança introduz o grupo familiar em um novo universo, ampliando seu espaço relacional, colocando-os em contato com sistemas e culturas de cuidado que antes não faziam parte de suas vidas e que alteram a lógica simbólica para o desempenho de papéis.

A aproximação entre o sistema familiar e o sistema profissional de cuidado de saúde, no ambiente hospitalar, é delimitada como um tempo na trajetória da doença e da vida familiar. Tal tempo é definido de diferentes maneiras, a depender de sua extensão e da forma como os indivíduos que compõem o sistema familiar se organizam para integrarem-se, bem como, das formas como partilham dessa experiência.

A doença, ao ampliar o espaço relacional do sistema familiar, colocando-o em contato com profissionais e instituições, compreendidos 
como sistemas e culturas de cuidado de saúde, em muitos aspectos divergentes da cultura familiar, introduz o grupo a uma experiência de socialização.

Assim, a depender de como o sistema se organiza para viver o tempo de hospitalização, integra-se à experiência de socialização e esta assume significados os quais, por sua vez, podem alterar a forma como a condição de vida é assimilada.

O tempo vivido no hospital pode ser visto como um tempo de aprendizado e, portanto, fundamental para a assimilação do conhecimento e das habilidades técnicas de cuidar; por outro, também pode ser visto como um tempo de ameaça à coesão interna e conexão do sistema familiar com sua rede social. Se por um lado a hospitalização prolongada pode gerar aprendizados, por outro também gera riscos para a vida familiar, pois desafia o sistema em seus esforços para manter-se integrado ao ter a vida familiar dividida entre a casa e o hospital.

O sentimento de ameaça às competências familiares, tanto para prover o cuidado, quanto para manter a coesão são potencializados pela distância da casa e entre os indivíduos que compõem a família, as limitações financeiras e pela vivência de fragilidade dos vínculos familiares, especialmente os vínculos conjugais. No entanto, a fragmentação do sistema familiar também pode ser secundária à própria forma como a assistência para a criança é organizada no ambiente hospitalar.

Assim, o tempo de hospitalização pode ser visto, tanto como um tempo de preparo para lidar com a condição da criança, que permite 0 desenvolvimento e fortalecimento das competências do sistema familiar, quanto um tempo de privação, de preparo quando o sistema familiar não consegue viver de forma integrada o processo de assimilação da experiência de doença e cuidado no hospital ou não dispõe de tempo ou de espaço para tal processo. 
[...] "eu acho assim... que se a gente não tivesse se esforçado em... em... que nem ela (esposa) falou, ninguém ensinou a gente a fazer nada com a L.(filha) aspirar, a trocar uma traqueo, a trocar uma sonda, ninguém nunca falou: 'olha vocês têm que fazer isso' e nem nada, a gente foi olhando e fazendo e aprendendo, eu acho que se a gente não tivesse feito isso, eu acho que hoje ela não estava em casa, estava no hospital ainda, por que... ninguém ensinou nada e você sabe que se a gente não for aprendendo isso aos poucos, que nem a gente teve esse tempo de um ano para ir aprendendo...então, a gente foi tendo esse tempo para poder ser adaptar, para poder cuidar, bem aos poucos, cicatrizando a ferida e... né?, acabou dando tudo certo, graças a Deus, a gente acabou sabendo fazer bem direitinho (risos)" [...] (Pai, família 4)

[...] MÃE: "a gente sofre pela falta de informação... (chorando, quase não consegue falar, faz uma pausa) PAl continua: E é aí que você sofre mais, você ver sua criança internada, ali sem se mexer, sem nada, é muito complicado, é onde o sofrimento é maior... sem saber o que está acontecendo, sem poder fazer nada... MÃE retoma a fala: o que me fez sofrer muito, foi que... não sentaram com a gente para passar o diagnóstico do $P$. (filho), cada dia que você ia visitar na UTI, era uma coisa diferente, ah... 0 seu filho tem fenda palatina, num outro dia era outra coisa... não teve aquela conversa, assim ... 'não, vamos sentar, conversar' , tipo... os médicos, a equipe tudo... então cada dia que você ia, ia passando... e ia ficando mais preocupada, não hoje o "P. (filho) tem a mão caída'... o 'P. tem o coração maior'... então aquilo ali... sabendo que eles mesmos, os médicos já sabiam, porque também, que o P. (filho) sofre de apnéia, tudo é por que?... mas cada dia falando coisa com coisa, você não sabe nada, né?... você fica insegura, cada dia era mais insegurança ainda, não passam tranquilidade, você ficava mais... era como se você não tivesse chão para pisar, tentava pisar e... ai, meu Deus, parece que ia cair... e cada dia isso aumentava [...] (Família 10)

Em muitos contextos assistenciais, a participação da família é condicionada às aprovações dos profissionais e, quando não encontra espaço para negociar, é totalmente excluída dos processos de tomada de decisão e os pais podem se deparar indo para casa com a criança sem o tempo de assimilação necessário e nem o preparo para assumirem a responsabilidade pelo cuidado. O que gera conflitos e faz que a assimilação da condição de vida da criança se mantenha como um desafio na vida familiar.

A privação de convívio familiar, devido às atitudes dos indivíduos que compõem o sistema familiar de modo a integrarem-se à experiência e proverem apoio mútuo ou barreiras institucionais que priorizam a presença materna e, ao mesmo tempo, geram impedimentos para a participação de 
outros, pode potencializar a fragmentação do sistema familiar, quando este já apresenta dificuldades de cooperação para a resolução dos problemas ou inabilidade de negociação de papéis, frente ao contato com sistemas sociais mais amplos ou em situações que se sentem destituídos de poder de decisão.

No processo de aprendizagem, os meios empreendidos por cada indivíduo e as barreiras sociais, limitações financeiras e jornada de trabalho, ou institucionais, limites e regras que encontram têm efeitos no sentimento de capacidade para lidar com a situação.

Dessa maneira, a mãe tende a viver de forma mais intensa o tempo de hospitalização, abdicando de suas demais funções sociais para estar presente de forma contínua, a fim de assimilar a condição da criança, enquanto o pai e os demais membros da família assumem papéis variados, a depender, sobretudo, de como interpretam seus deveres e obrigações mútuas, da habilidade e do espaço que encontram para negociar suas participações nos eventos que acompanham a doença da criança, o que, muitas vezes, faz que se sintam impedidos de participar. Em outras situações, as ações daqueles que não participam são interpretadas como ausência de compromisso e de lealdade com o grupo familiar, experienciados como desamor nas relações familiares.

O processo de assimilação da condição da criança exige, além de habilidades cognitivas e comunicacionais, um reordenamento de vínculos, papéis e funções dentro do sistema familiar. Por sua vez, alguns indivíduos tendem a tornarem-se personagens centrais na cena do cuidado e outros periféricos ou completamente excluídos. O que gera ou expõe o comprometimento do sistema familiar, devido à sua maior ou menor capacidade de desenvolvimento de papéis e funções complementares que possibilitam o apoio mútuo e a manutenção de um funcionamento efetivo ao longo da experiência.

Desse modo, diante da necessidade de aprendizado, como uma condição que permite que os pais e a família se mantenham de forma 
constante na vida da criança, estes se organizam de diferentes modos para assimilar o conhecimento e as habilidades técnicas de cuidar.

[...] "Eles (profissionais) viram a minha vontade de trazer ela (filha) para casa, teve mãe que já não demonstrou tanta vontade entendeu, que nem eu que abri mão de tudo assim, que nem eles (profissionais) achavam que no começo eu iria ter essa vontade, mas que depois eu iria cansar, né?, assim... de abrir mão do serviço, da vida que eu tinha... então eles viram isso, e foram me ajudando assim, me ensinando os cuidados que ia ter com a S. em casa, ensinado eu aspirar, né?, tudo aquilo que eu iria ter que ter, tudo que elas faziam lá né?, ai elas (enfermeiras) passavam isso para mim, isso foi muito bom, né?, por que eu aprendi tudo muito rápido, então foi muito assim, muito mais fácil, para eu trazer, sabe?, teve mãe que demorou mais, por que não tinham coragem... aí elas (enfermeiras) falavam para mim que não era para eu pensar, tipo assim, quando eu ia aspirar a S., começava a colocar a sonda e já tirava, por que para mim aquilo doía dentro do peito assim, aí elas (enfermeiras) falavam assim, 'não S., você tem que pensar que você não está fazendo isso para machucar ela, você está fazendo isso como um bem para ela' sabe? essas coisas, assim, elas conversavam muito comigo, elas falavam 'é que nem a gente, quando a gente vai puncionar uma criança, a gente não pensa que está fazendo ela chorar de dor, não, a gente está pegando a veia para dar remédio, para poder sarar', sabe? Nossa! elas conversavam muito comigo, aí acho que você vai criando mais coragem para fazer as coisas, porque no começo é muito difícil” [...] (Mãe, família 3).

[...] 'Não é que eles falem 'vocês tem que fazer isso, isso e isso'... a gente prestava atenção em tudo, assim que chegou lá (hospital) como tem acompanhante, eles (profissionais) deixam por nossa conta, os cuidados, e eu cuidei da L. lá tudo, quando chegou lá (no hospital) as meninas de enfermagem perguntaram 'você sabe aspirar?' e eu falei 'sei', de ver a gente acaba aprendendo... ele (esposo) também faz tudo, ele ia lá (hospital) também, segunda, quarta e sexta, saia as duas horas do serviço, chegava lá as 6 horas da tarde, e chegava em casa de volta eram umas onze horas da noite... ficava lá uma hora e meia, foi bem puxado, ela (filha) ficou onze meses e quinze dias lá (hospital), e eu ficava com ela de segunda até sábado, sábado a tarde eu vinha para casa e voltava na segunda de manhã, e ele (esposo/pai) ia na segunda, quarta e sexta, só na quarta que ele (esposo/pai) ia mais cedo, que era folga dele, ele ia mais cedo e ficava o dia todo com a gente... final de semana eu vinha para casa, ele (esposo) fazia comida, chegava já estava tudo pronto, cuidava de mim, e na segunda eu voltava... e essa é a história...então a gente foi aprendendo assim... do nosso jeito" [...] (Mãe, família 4)

Os modos de organização familiar podem refletir, tanto padrões culturais determinantes para a associação do cuidado, quanto uma função predominantemente feminina, como padrões prévios de interação familiar, que evidenciam resistência e rigidez diante da necessidade de 
transformação ou padrões de interação adaptativos, que permitem flexibilidade para absorver as mudanças. Tais padrões, por sua vez, podem interferir na capacidade do sistema em lidar com a situação e gerar diferentes níveis de percepção de ameaça ao projeto de vida familiar.

Diante das diferentes percepções de ameaça ao projeto de vida familiar, seja por conta da condição da criança, diante do tempo prolongado de hospitalização ou diante da exposição da fragilidade dos vínculos familiares, voltar a viver com a criança em casa passa a ser visto como uma possibilidade concreta de se reduzir os riscos e de reintegrar a vida familiar no espaço que the pertence e, portanto, passa a se configurar como uma possibilidade de resgate da capacidade de autodirecionamento da vida pessoal e familiar.

Desse modo, a concepção de que viver no hospital não pode ser uma condição definitiva na vida da criança e da família, motiva os indivíduos, fragmentados ou unidos, a direcionarem seus esforços à meta de voltar com a criança para casa. Então, a decisão de voltar a viver com a criança em casa, pode partir da família e esta precisa negociar com o sistema profissional para conseguir atingir as competências necessárias para prover o cuidado no domicilio.

Diante dessa definição, os indivíduos que compõem o sistema vão assimilando a condição da criança, ao empreenderem esforços para a participação das ações de cuidado e de tomada de decisão; e, com isso, vão adquirindo consciência das implicações definitivas da situação na vida familiar, o que pode reduzir ou aumentar as tensões entre o futuro sonhado, a realidade de vida e a percepção de capacidade para lidar com a situação em seu próprio ambiente.

Entretanto, a concepção dos pais segundo a qual devem ser constantes na vida da criança e voltar com ela para casa é o meio de integrar a vida familiar, o que motiva a presença, por vezes, solitária da mãe e, por outras, partilhada dos pais com outros membros da família, junto da 
criança de forma a irem inteirando-se de suas necessidades de cuidado e irem assimilando a cultura técnica de cuidado.

Ao irem assimilando a cultura técnica do cuidado os pais e demais membros da família que encontram espaço para participação, vão adquirindo conhecimentos, adquirindo habilidades, desenvolvendo papéis, desenvolvendo padrões de comportamento adaptativos ou reproduzindo padrões de comportamento. Os padrões de comportamento são influenciados, sobretudo, pela forma como interagem entre si, com a situação da criança, pelos valores construídos ao longo de sua história e pela forma com interagem, absorvendo os valores e símbolos, por meio da tecnologia de cuidado e da comunicação estabelecida com os profissionais de saúde.

Desse modo, a assimilação da cultura técnica de cuidado pode resultar em incorporando a cultura ou integrando a cultura. A incorporação da cultura técnica do cuidado leva à reprodução dos padrões organizacionais, de comportamento e de valores do sistema profissional no ambiente doméstico, o que pode acentuar a dificuldade e o conflito nas relações familiares. Enquanto que, na integração da cultura técnica do cuidado, os valores assimilados e as habilidades adquiridas são ajustados à cultura familiar, o que tende facilitar a forma como absorvem e lidam com a condição no ambiente doméstico e a cooperação nas relações familiares.

Esses dois modos distintos de assimilação refletem a forma como os indivíduos se organizam e se preparam para lidar com a condição de vida, em suas dimensões instrumentais e comunicacionais e, por sua vez, a capacidade de sociabilidade do sistema familiar.

A forma como o sistema familiar se organiza para participar dos processos de assimilação da condição de vida, mais integrado ou fracionado, a fim de possibilitar a intercomunicação, a expressão de sentimentos e a circulação de informações, pode propiciar tanto a integração, quanto desintegração entre as vivências e aprendizados. O que terá reflexos definitivos na forma de como ordenam a vida privada e seguem 
suas vidas. A desintegração entre as vivências e aprendizados gera desacordo entre os significados das dimensões da realidade percebidos, sentidos, vividos, interpretados e possíveis de serem comunicados.

A experiência de socialização, como um meio de assimilar a condição, a cultura técnica e de tornarem-se preparados para assumir as responsabilidades e lidarem com a condição de vida da criança e de vida familiar, é um processo complexo, envolve reorganização cognitivo-afetiva, estrutural e funcional do sistema familiar, de forma a internalizar as mudanças em seus referenciais simbólicos de ação e interação.

Entretanto, ao mesmo tempo em que precisam assimilar a nova condição de vida e a cultura técnica de cuidado, também precisam desenvolver meios de preservar a cultura e a identidade familiar. Enquanto adquirem o preparo para assumir novos papéis, também precisam preservar papéis e valores que fazem parte da biografia e da identidade individual e coletiva.

Desse modo, o processo de assimilação da condição de vida, pode conduzir, tanto a uma desorganização pessoal e familiar diante da perda de capacidade de autodeterminação, quanto a uma reorganização pessoal e familiar, caracterizada pelo sentimento de confiança em si mesmos e de autodeterminação, dada a capacidade de definir situações e tomar decisões e, portanto, direcionar projetos, mantendo referências e valores sociais, culturais e familiares.

A participação integrada do sistema familiar nos processos que promovem a assimilação da condição de vida capacita para a tomada de decisão partilhada e ajuda os indivíduos a tornarem-se conscientes das consequências de suas decisões em um longo prazo, bem como, das alterações definitivas que devem ser incorporadas à vida familiar, quando se tornam decididos a voltar a viver com a criança em casa.

O espaço que o sistema familiar encontra para negociar entre si e com os sistemas de cuidado de saúde, acerca de suas expectativas, medos, 
dúvidas, desejos e metas, pode fortalecer ou fragilizar os indivíduos, diante do conjunto de desafios e obrigações que assumem, ao decidir levar a criança para casa.

Além da forma como participam, vivem e interpretam os eventos que acompanham a trajetória da doença da criança, o tempo assume uma dimensão determinante para o sentimento de incapacidade ou de capacidade para lidar com a situação. Os indivíduos precisam de tempo para assimilar a dimensão desse evento na vida familiar, se conformar com a doença e a condição de vida, acomodar a realidade dentro si mesmos e do contexto de vida familiar, de forma a entrarem em acordo com a circunstância definitiva de vida. Além de tempo, muitos precisam ser apoiados e fortalecidos nesse processo.

Desse modo, a capacidade para lidar com a situação envolve mais que a aquisição de habilidades complexas de cuidado e de domínio da condição da criança. A decisão de inserção do cuidado da criança ao ambiente familiar demanda mais que preparo para assumir o papel de cuidares e a responsabilidade pela preservação da vida da criança.

Ao irem assimilando as transformações geradas nas circunstâncias de vida familiar, os indivíduos também vão elaborando suas possibilidades de vida, frente às condições e opções que dispõem para a inserção do cuidado da criança ao ambiente familiar.

Desse modo, ao sentirem-se ameaçados em suas competências para prover o cuidado no ambiente domiciliar, os indivíduos se engajam em um processo mental de elaboração das possibilidades de vida. Em muitas circunstâncias a elaboração das possibilidades de vida restringe-se às vivências no hospital e, ir para casa com a criança, passa a ser visto como o meio de sair de uma condição de reclusão e de privação de convívio, o que não permite espaço para pensar nas implicações em um longo prazo.

A urgência de voltar para casa com a criança, e sair de uma condição de reclusão, é expressa de forma mais contundente, quando o sistema vive 
a esse tempo de forma fragmentada. Especialmente, quando um membro da família, em geral, a mãe, vive o tempo de hospitalização de forma solitária e não consegue lidar com a angústia do afastamento de seus demais papéis e funções sociais.

Em outras situações familiares a elaboração das possibilidades de vida envolve mais do que o desejo de sair de uma condição de privação, de convívio, e sim tornar-se um processo cuidadosamente incorporado ao raciocínio empregado pela família para definir e agir em suas situações, de forma a tornarem-se conscientes e seguros na decisão de levar a criança para a casa. Quando a família vive esse tempo de forma integrada, consegue controlar a angústia da espera para voltar para casa e obtém maior sucesso na forma como assimila a condição de vida e ordena a cena doméstica.

[...] PAI: "quando eu falei que queria trazer minha filha para casa a primeira coisa que eu ouvi foi: 'você quer levar sua filha para casa, mas você não tem condições? Você tem condições? Para levar sua filha para casa precisa disso, disso, disso', fez (médico) uma lista de coisas que precisava, respirador tudo... tudo dava uns 65 mil reais. Aí, ele (médico) perguntou 'você tem condições de levar a sua filha para casa?' Aí eu (pai) respondi, 'não hoje eu não tenho, mas eu tenho boca, braços e pernas e eu vou conseguir' MÃE continua: "a decisão partiu de a gente estar conversando, porque você imagina, a gente pensou, pensou e conversou. Imagina a L. sendo transferida para outro hospital, mesmo lá na UTI ela era esperta, ela brincava... então a gente pensou, a gente não vai poder ficar lá (no outro hospital). Hoje, eu acho que se ela estivesse no hospital, ela não estaria mais viva, porque iria sentir falta da gente, do amor, do carinho, do afeto que a gente dá para ela... então a gente se uniu, no começo a gente falou assim, vai ser difícil, é difícil, porque muda, a rotina, tive que parar de trabalhar, porque eu trabalhava fora né?, tive que parar de trabalhar... então a gente se uniu e disse não, vamos levar ela para casa, porque com a gente, ela estando em casa, lá vai ser melhor para ela, é meio cansativo tem dias, com a gente, mas... está dando tudo certo, ela esta bem... foi uma decisão tomada assim... da gente mesmo... vamos levar ela!" [...] (Família 1)

[...] "eu só queria sair de lá (hospital), eu fiquei muito tempo lá, e eu não vivi, eu ficava só trancada naquele hospital, comendo aquela comida, não que seja ruim, mas é muito chato... eu não saia do quarto para ficar assistindo televisão com as outras mães, eu só ficava ali dentro do quarto, eu não quero mais ficar lá naquele lugar fechado, meu medo é ela ficar lá internada de novo" [...] (Mãe, família 2) 
Assim, às expectativas e ao desejo de voltar para casa, adicionam-se os pensamentos de acerca das condições concretas que a família dispõe em seu meio para atender as demandas de cuidado da criança e da unidade familiar. Além de pensar nos benefícios de cuidar em casa, o pensamento é orientado a avaliar as condições da família, pensando nas condições financeiras, pensando nos custos do cuidado e pensando nas escolhas definitivas que terão que incorporar à vida familiar. A avaliação das condições da família diante das demandas da doença e necessidades especiais de cuidado da criança, bem como, de suas possibilidades de mobilizar os recursos, se torna um parâmetro para a persistência em levar a criança para casa.

Entretanto, a necessidade emocional de voltar para casa com a criança, faz que muitos grupos familiares pensem apenas nos potenciais benefícios que o cuidado domiciliar possa ter para a criança e para a família. Quando essa necessidade se torna a base para a persistência na decisão de levar a criança para casa, as potenciais dificuldades ou riscos adicionais não são visualizados.

A avaliação das condições da família também é um parâmetro da equipe de saúde e influencia na forma como a família é vista e qual o tratamento que recebe no ambiente hospitalar. Em algumas situações, diante da elaboração de possibilidade de vida que a família faz, se vê lutando para levar a criança para casa, encarando os múltiplos desafios de forma a superar as condições impostas pela equipe e provar que é capaz de cuidar da criança em seu próprio ambiente. Em outras situações, a família não tem nem tempo para elaborar suas possibilidades de vida e se vê tendo que cuidar da criança em casa. O que faz que algumas famílias interpretem o cuidar da criança em casa como uma vitória e, em outras situações, como algo assustador.

Assim, a elaboração das possibilidades de vida fornece as bases simbólicas para decisão de voltar a viver com a criança em casa; entretanto 
se mantém como um processo contínuo, diante da necessidade constante de assimilação dos novos desafios e mudanças que surgem na vida familiar.

Desse modo, ao elaborarem suas possibilidades de vida, o sistema familiar pode sentir-se, tanto capaz, quanto incapaz de lidar com a situação, frente ao sentimento de preparo, frente ao apoio disponível, frente à característica dos vínculos familiares e à habilidade para ativar sistemas de apoio, pedir e aceitar ajuda de forma a mobilizar recursos instrumentais e econômicos. E, diante da necessidade de conexão interna e com a rede familiar e social, como formas primárias de apoio emocional.

Logo, o processo de assimilação da condição de vida da criança e da família, tem como consequência: sentindo-se capaz de lidar com a situação ou sentindo-se incapaz de lidar com a situação, o que por sua vez tem relação com a história, com os sistemas de significados, com tempo vivenciado, as fragilidades presentes na vida familiar $e$ as forças desenvolvidas, as quais podem facilitar o ajustamento à situação ou potencializar o sentimento de ameaça ao projeto de vida familiar.

\section{SENTINDO-SE CAPAZ DE LIDAR COM A SITUAÇÃO}

A capacidade em lidar com a situação reflete um conjunto de forças desenvolvidas frente às circunstâncias de vida e à integração dos indivíduos que compõem o sistema familiar. A capacidade de lidar com a situação se manifesta na forma como organizam a vida privada.

A capacidade do sistema familiar em lidar com a situação representa a consequência da forma como seus integrantes assimilam a condição de vida da criança e da família, expressas em um conjunto de habilidades cognitivas, instrumentais e expressivas, conjunto este que envolve a habilidade de conformar-se à situação, a habilidade para negociar expectativas de vida, o preparo para cuidar, as habilidades comunicacionais direcionadas à resolução de problemas, a habilidade para negociar papéis, a 
habilidade para a manutenção da coesão do sistema familiar e a habilidade para ativar sistemas de apoio. Tais habilidades refletem a capacidade do sistema familiar desenvolver padrões adaptativos, que evidenciam a flexibilidade do sistema ao entrar em contato com diferentes padrões culturais e a integração destes na totalidade de seu universo simbólico.

Portanto, conformando-se à situação é uma habilidade cognitiva de aceitação, gerada a partir de estratégias de atribuição de significados e de valores positivos à criança e de sua condição de vida, que são partilhados e fortalecidos na relação estabelecida entre os pais, de forma a entrarem em acordo mútuo e internalizarem tais valores e definições como parte da construção de suas identidades parentais. A conformação à situação permite a acomodação da realidade e o fortalecimento da identidade parental. Os pais tornam-se confiantes para encarar os desafios, os questionamentos e as reações sociais.

[...] "eu falo que o meu é especial, meu é especial, tem cuidados diferentes dos outros, então eu já coloco na minha consciência 'meu filho é especial', 'ah o que seu filho tem, e isso e aquilo', 'ele é dependente de um oxigênio', 'ah mas ele anda', eu falo 'ele anda, ele conversa, ele tudo, mais ele precisa da comida na boca, ele precisa ter tempo só para ele, então ele é especial', eu já estou conformada com isso, sinto vontade de sair? Sinto. Meu marido está de férias, domingo e tal, ontem a gente achou de juntar a família, a gente assou uma carnezinha aqui, ai um dos parentes meu veio, e um dos parentes dele veio, e daí quando chegou a noite, ele falou 'ah foi tudo bem né?', 'ah esta tudo bem', esta bom esta todo mundo em casa, o filho esta em casa, para que melhor, então ele esta de férias, a gente podia estar viajando ne? Nas condições que dava, mas a gente podia estar viajando, ir para o norte isso e aquilo, mas como eu vou na Bahia com ele? Eu já estou conformar com isso" [...] (Mãe, família 8)

Os valores e definições construídos pelos pais são transmitidos nas interações com demais membros da família, como forma de prover uma perspectiva partilhada da situação da criança. A conformação à situação permite aos pais adequarem suas ações conforme as demandas da criança, o que por sua vez permite o ajustamento destas às demandas da vida familiar. 
Ao conformarem-se à situação, os pais vão construindo uma "nova" normalidade para a criança e para suas vidas negociando expectativas de vida familiar.

Negociando expectativas de vida familiar refere-se à habilidade para aceitar novas restrições e os novos sacrifícios que passam a fazer parte da vida familiar como forma de acolher a condição da criança. Desse modo, negociar expectativas de vida envolve um conjunto de estratégias direcionadas a entrar em acordo com as decisões que acompanham a trajetória de cuidado da criança e que, por sua vez, transformam e geram limitações à vida familiar.

Negociar expectativas de vida familiar requer a substituição de um significado por outro igualmente efetivo. Desse modo, ao deixar o trabalho para cuidar do filho, o significado do trabalho materno é sobreposto pelo significado do cuidado, o que permite à mãe entrar em acordo com suas escolhas. O cuidado é visto como um meio de preservar a vida da criança e a coesão do grupo, o que traz em si satisfação. Assim como o significado da vida pessoal e familiar é transformado de forma a permitir adequação ao fato de viver dentro de casa, como uma limitação imposta pela condição de vida da criança.

A negociação das expectativas de vida é pautada nos valores atribuídos às relações interpessoais e aos significados positivos, associados a elementos da dinâmica familiar, como o valor de partilhar sentimentos, preocupações, visões, aprendizados e recursos.

A negociação das expectativas de vida, por sua vez, também permite o desenvolvimento de habilidades de negociação de papéis e funções dentro do sistema familiar.

Ao ir negociando papéis, o sistema familiar como um todo se capacita para o cuidado da criança e para o desempenho de suas demais funções vitais de apoio mútuo, sustento, proteção e de socialização de seus 
membros. Essa é uma habilidade contínua do sistema de forma a manter o funcionamento efetivo.

Negociar papéis é uma habilidade que permite o desenvolvimento de padrões de complementaridade dentro do sistema familiar, onde papéis de homens e mulheres, de trabalhador ou de cuidador não são estáticos ou contrapostos, mas sim complementares e integrados à dinâmica familiar. $\mathrm{A}$ negociação de papéis permite o desenvolvimento de padrões de ajuda, de aprendizagem partilhada e de afetividade, o que facilita a aceitação de novas funções ou suas substituições.

A constante negociação de papéis e suas reconstruções expressam as características de sociabilidade, como uma qualidade sistêmica que permite $\mathrm{o}$ desenvolvimento e $\mathrm{o}$ fortalecimento da identidade familiar na situação de viver com uma criança com necessidades especiais de cuidado.

Desse modo, a negociação de papéis se torna uma habilidade fundamental que permite o preparo do sistema familiar para integrar a função de cuidar da criança com necessidades especiais de saúde.

Sentindo-se preparados para cuidar apresenta-se como consequência da interação desenvolvida com os sistemas profissionais de saúde promotores do fortalecimento das competências familiares para prover 0 cuidado no ambiente familiar e da integração da cultura técnica à cultura familiar de cuidado de saúde.

O sentimento de preparo para cuidar da criança com necessidades especiais de saúde envolve a aquisição de forças e de confiança para o desempenho do papel de cuidadores.

[...] Pai: "a gente já estava interado com o cotidiano dela (filha), então tudo que acontece com ela (filha) a gente está inteirado, esta sempre por dentro, por que nesse ponto, quando se trata dela (filha), eles (profissionais) não escondem nada, tipo, eles (profissionais) já falam na bucha o que vai ser e o que não vai ser, não tem meio termo, não tem meio diagnóstico, eles já falam tudo na lata para a gente... então assim... a gente já sabia que ela (filha) iria vir, até mesmo pelo tempo que ela (filha) ficou lá no quarto separado (no Hospital), a gente já sabia quando ela (filha) ia vir para casa, o que ela (filha) precisava e o que a gente podia 
disponibilizar para ela (filha), entendeu? então a gente... vamos dizer... assim... de ela (filha) vir para casa e precisar de alguma coisa ... de suporte... técnico..." MÃE completa: "foi tudo tranquilo"...PAl continua: "foi tudo tranquilo... graças a Deus... a gente acaba... a gente vive tanto quando ela (filha) está no hospital, a gente vive tanto para isso, tentando se atualizar, tentando se inteirar do que está acontecendo, que... quando vem para casa a gente já está tão... como é... adaptado... que..." MÃE completa: "já não é mais tão novidade..." PAl completa:... já não é um bicho de sete cabeças né? (Família 4)

As forças relacionadas ao desempenho do papel de cuidadores envolvem habilidades de atribuição de significados efetivos à natureza do cuidado que é provido para a criança, de uma ação que causa dor e sofrimento para uma ação que mantém a vida.

O preparo para cuidar também envolve aquisição de conhecimentos que capacitam à compreensão da condição da criança, de suas fragilidades, limitações e necessidades, bem como, de habilidades instrumentais altamente técnicas e complexas, habilidades de julgamentos médicos e a habilidade para a tomada de decisão contínua em relação ao melhor cuidado para a criança de forma a ajustar as necessidades da criança aos recursos disponíveis no contexto de vida familiar.

O preparo para cuidar também envolve a habilidade para manejar as complexas responsabilidades, as obrigações, os custos e a carga de trabalho que acompanham a inserção do cuidado no domicílio. Ele exige aprendizado e perspectivas partilhadas, negociação de papéis e expectativas dentro do sistema familiar, de forma a que todos possam viver a experiência de cuidar de forma integrada. Quando isso ocorre, os indivíduos, além de tecnicamente habilidosos, tornam-se confiantes e seguros em suas competências de cuidar e manter a coesão do sistema.

Dessa maneira, as habilidades de comunicação direcionadas à resolução dos problemas são potencializadas, pois todos falam a mesma linguagem dentro do sistema familiar, o que capacita o entendimento mútuo e o constante alinhamento de forças internas e a busca de forças e recursos externos. 
A habilidade em manter a coesão do sistema é fortalecida pelo desempenho de papéis complementares; nele cada ação é alinhada à ação do outro de forma a prover apoio mútuo. Os indivíduos que compõem o sistema desenvolvem sensibilidade única para adequar suas ações de cuidado à criança, mas também para identificar as necessidades dos demais membros da família e articular o apoio.

Desse modo, a abertura para o diálogo, dentro do sistema familiar e com outros sistemas mais amplos, permite criatividade para a solução dos problemas. As estratégias de resolução são criadas na comunicação sobre os problemas o que permite a circulação de informações, de ideias, de opiniões que ocorre na conexão com os sistemas comunitários, profissionais e entre famílias que vivem com crianças com necessidades especiais de cuidado.

\section{SENTINDO-SE INCAPAZ DE LIDAR COM A SITUAÇÃO}

A incapacidade em lidar com a situação reflete a fragilidade diante das circunstâncias de vida e a ausência de integração entre os indivíduos que compõem o sistema familiar. A incapacidade em lidar com a situação é refletida na forma como organizam e significam a vida privada.

A incapacidade do sistema familiar em lidar com a situação representa a consequência da forma como assimilam a condição de vida da criança, da família e as dificuldades cognitivas, instrumentais e expressivas presentes na vida familiar. Tais dificuldades refletem a rigidez e a reprodução de padrões comportamentais, o que gera impedimentos para a transformação dos indivíduos e do sistema familiar para integrarem às mudanças em seus referenciais simbólicos para atuação.

Desse modo, o sistema pode experienciar os diferentes níveis de dificuldade e sobrecarga, que envolvem a dificuldade em conforma-se à situação, a inabilidade de negociação de papéis, o sentimento de 
despreparo para cuidar, as barreiras comunicacionais que dificultam a resolução dos problemas e a busca de sistemas de apoio.

A forma como os pais assimilam a condição da criança pode gerar impedimentos para a aceitação. Assim, não se conformando à situação reflete a dificuldade dos pais, especialmente da mãe, de internalizar a condição da criança, como parte da construção de suas identidades parentais. O que implica em viver entre o sonho de se ter um filho normal e a realidade de ter um filho com necessidades especiais de saúde.

A dificuldade de conformação à situação, por sua vez, conduz a constantes tensões e conflitos secundários à fragilidade da identidade parental. Os pais sentem-se diferentes dos demais pais e expostos aos julgamentos sociais, o que potencializa a angústia vivida por eles. A situação da criança é vista como algo que gera pesar em si mesmos e nos outros.

A não conformação à situação gera ações que vão além das demandas da criança. Os pais agem de acordo com suas crenças e necessidades de normalizar a vida da criança. $O$ intenso investimento de estratégias focalizadas a normalizar a vida da criança, não permite a adequação de esforços direcionados às demais demandas da vida familiar. A normalização da vida da criança aqui é simbolizada como "curar a doença".

[...] "Tantas vezes eu briguei com meu irmão, meu cunhado porque assim eles falavam que a minha filha era especial, e eu 'não minha filha não é especial', por esse gênio meu, por esse jeito meu, eu não sei o que ajudou até então o desenvolvimento da E. (filha), porque a Síndrome de West, não sei se você já ouviu falar da síndrome de West, a criança não tem muito movimento...você já viu uma criança com Síndrome de West? A criança fica parada, a criança não tem movimento nenhum, ela não se mexe, a minha filha é totalmente diferente... quando alguém falava, sua filha tem problema, eu falava, 'minha filha não tem problema, minha filha nasceu de seis meses', 'ai que ela parece...', daí eu 'ah não parece nada. Eu fui perdendo as pessoas sabe?.Eu não aceito que ela fique parada [...] (Mãe, família 7) 
A inabilidade de conformar-se à situação gera dificuldades para a aceitação dos sacrifícios e restrições que passam a fazer parte da vida familiar. Os pais, especialmente a mãe, passam a viver a tensão constante entre as renúncias que acompanham e a escolha de cuidar e preservar vida da criança no domicílio.

Ao mesmo tempo em que querem cuidar e preservar a vida da criança, os pais não se conformam com as limitações e com a dependência que a criança gera na vida pessoal e familiar. O que conduz à atribuição de significados negativos a elementos da dinâmica familiar alterada pela doença e dependência da criança. O cuidado é visto como uma ação que aprisiona. Desse modo, o viver dentro de casa é visto como uma experiência de reclusão social.

A dificuldade de conforma-se a situação conduz a sentimentos e ações desagregadores dentro do sistema familiar. Especialmente quando a intensa sobrecarga física e emocional não é partilhada nas relações familiares.

Desse modo, a inabilidade de negociar papéis, associa-se à dificuldade conformar-se com a situação, potencializando o desequilíbrio do sistema familiar. Ao agirem não negociando papéis, a tendência é o desempenho de papéis isolados, onde cada indivíduo dentro do sistema se especializa em uma única função e vão estabelecendo esferas de atuação que, por vezes, não se conectam com o todo. Enquanto que a mãe assume o papel de cuidadora e especializa-se na função de cuidar da criança com necessidades especiais, o pai pode mergulhar cada vez mais no trabalho e em suas funções de sustento econômico da unidade familiar. Assim, cada um interpreta que está fazendo sua parte, sem negociar as expectativas de vida familiar. A ausência de negociação de papéis não permite que o sistema como um todo se capacite para o cuidado da criança. O que gera sobrecarga e compromete o desempenho de suas demais funções vitais de apoio mútuo, proteção e de socialização de seus membros. 
A inabilidade para negociar papéis compromete o desenvolvimento de padrões de ajuda, de aprendizagem partilhada e de afetividade. O que, por sua vez, dificulta a inserção da função de cuidar da criança com necessidades especiais na dinâmica das relações familiares.

A inabilidade de negociação de papéis, tanto dentro do sistema familiar, quanto com os profissionais de saúde, gera o sentimento de despreparo para cuidar, como uma qualidade interacional que permite $o$ fortalecimento da unidade familiar.

Sentindo-se despreparado para cuidar apresenta-se como consequência da dificuldade de assimilação da condição e das necessidades da criança, de privação de tempo de preparo ou de ausência de vivências e aprendizagens partilhadas.

O preparo para viver em casa, com a condição de ter uma criança com necessidades especiais de saúde, que demanda cuidados complexos e dependerá continuamente dos pais, influencia a forma como o sistema familiar se organiza e reflete um maior ou menor controle sobre suas vidas, articulado ao senso de incapacidade para lidar com situação.

Os pais vivenciam tensões e conflitos relacionados à insegurança de terem que assumir a responsabilidade de cuidar da criança no domicílio, sem o preparo necessário. Diante do sentimento de despreparo, a experiência de cuidar da criança se torna ameaçadora para os pais que se veem tendo que agir em uma situação que não sabem definir, seja pela falta de informações ou pelo choque entre o imaginado que seria o cuidado em casa e a realidade.

[...] MÃE: "Foi um choque para ele (esposo/pai) e para todos nós né $\mathrm{N}$. (falando com o esposo), na época que o P. estava na UTI, você perguntava para eles, e eles não explicavam que o $P$. ia sair de sonda não é?" PAl continua: é e... de repente você vir para casa com uma criança com sonda, com vários cuidados complexos... isso... gera um conflito, para você mesmo gera um conflito, não saber lidar, não saber o que na realidade, o que é real e o que não é... quando o P. saiu do hospital, ele não tinha nada, nem um encaminhamento, nada, nem para tratamento nada... aí através de uma amiga dela (esposa) a gente ficou sabendo de uma instituição [...] (Família, 10) 
[...] "eu achei difícil porque eu não tinha experiência, não tinha experiência de nada, eu senti difícil, com um ano de idade quando ele (filho) veio para casa, os médicos não tinham certeza se ele precisava do oxigênio, então ficava naquela, eu vinha para casa, daí de repente ele (filho) precisava, eu tinha que sair correndo com o inalador ligado nele, ligava para ambulância, tinha que ficar com o inalador ligado nele, porque não tinha suporte de atendimento, ele ficava roxo, ai chegava no hospital depois que os médicos vinham diagnosticar 'S. ele vai ter que usar um oxigênio também, para você controlar o U. em casa, para ele ficar em casa ele vai ter que ter usar oxigênio', ai ficamos pensando 'o que nós vamos fazer com isso? Como? Comprar? onde vamos comprar isso?' Nós não tínhamos noção de nada, foi muito difícil" [...] (Mãe, família 8)

Ao sentirem-se despreparados para cuidar, os pais tornam-se excessivamente dependentes dos profissionais de saúde, tanto para prover cuidados complexos, quanto para a obtenção de conhecimentos sobre a condição da criança. Quando os pais não dispõem da habilidade de negociação com os sistemas de saúde ou quando não são inclusos como clientes dos serviços pelos profissionais, a fragilidade diante da ausência e preparo é acentuada, o que gera dificuldades na vida familiar.

A ausência de preparo, adicionada à dificuldade de estabelecer um vínculo efetivo com os profissionais, seja pela desconfiança, seja pela instabilidade da assistência domiciliar, geram um intenso desgaste emocional e não permitem aos pais concentrarem-se sua atenção em outros aspectos da vida familiar, direcionando todo o tempo e os esforços para adequar os serviços disponíveis às necessidades da criança e da família e também adquirir o conhecimento sobre a condição da criança.

O desespero dos pais diante de uma situação que não sabem como lidar, somado a ausência de informação sobre os direitos da criança, faz que tomem decisões imponderadas e esgotem seus escassos recursos e bens materiais como forma de amparar a criança no domicílio.

O sentimento de despreparo para cuidar também pode surgir como consequência da forma como o cuidado é assimilado e refletir a incorporação da cultura profissional. Nesse padrão, apenas aquele que recebe 0 treinamento necessário é capaz de cuidar. $O$ que gera 
impedimentos para a participação de outros membros da família, quando tal preparo é vivido de forma individualizada e os membros não dispõem de habilidade para negociar papéis dentro do sistema familiar ou valores associados ao aprendizado partilhado. A incorporação da cultura técnicohospitalar de cuidado reflete a rigidez do sistema familiar, diante de exigências funcionais adaptativas.

Desse modo, o sentimento de despreparo para cuidar, reflete a inabilidade para o manejo das complexas responsabilidades, custos e carga de trabalho.

O sentimento de despreparo para cuidar, articulado à incapacidade para lidar com situação, juntos, refletem as dificuldades instrumentais e também comunicacionais do sistema familiar.

A dificuldade de comunicação direcionada à busca de soluções partilhadas para os problemas não permite o entendimento mútuo e alinhamento de forças internas ou mesmo a busca de recursos ou aceitação de ajuda externa.

Os sentimentos de capacidade ou incapacidade para lidar com a situação, por sua vez, configuram-se como elementos interacionais dinâmicos que passam a fazer parte da vida familiar, dada instabilidade e constante necessidade de adaptação.

A capacidade ou incapacidade desenvolvida ao longo da assimilação da condição de vida influencia a maneira como os indivíduos estabelecem o projeto de vida familiar e seguem suas vidas, sendo, portanto, determinante da maneira como vivem a transição, inserem o cuidado da criança no ambiente familiar, de como ordenam a cena doméstica e significam o viver dentro de casa. 


\section{VIVENDO DENTRO DE CASA}

Viver em casa com a criança com necessidades especiais de saúde representa a possibilidade de manter a integração do sistema familiar com e em seu ambiente social e representa uma vitória diante da trajetória de luta, de persistência e de superação de desafios empreendida para que o desejo e a meta de voltar a viver com a criança em casa se concretizassem na experiência da família.

Ainda que possa se apresentar como uma experiência assustadora e desafiadora, o estar em casa é visto como uma vitória em relação à doença, diante das limitadas chances de vida da criança.

No entanto, viver em casa com a criança, impõe ao sistema familiar restrições e sacrifícios constantes. O "viver dentro de casa" se sobrepõe ao "viver fora de casa", se antes a família vivia a maior parte do tempo fora de casa, pela extensa jornada de trabalho e atividades sociais que se davam no âmbito da comunidade e a casa era vista como lugar de descanso, essa relação com a casa e com a vida fora de casa se altera. A casa é o lugar do trabalho e do sacrifício e é o lugar da família e que também contém a dor e o sofrimento.

A "vida social" que se dava no âmbito público é consumida pelas demandas da "vida privada". A vida familiar, predominantemente, ocorre "dentro de casa", dada a imobilidade gerada pela dependência e limitação da criança. A casa torna-se um dos únicos espaços de possibilidade de convívio partilhado por todos os membros da família e entre estes e as demais pessoas significativas que compõem a rede social familiar.

Viver em casa com a criança com necessidades especiais de saúde requer habilidades constantes do sistema familiar, para lidar com essa condição circunstancial de vida, com as restrições e os sacrifícios, o que determina um movimento de continuidade da luta. 
A luta diária empreendida pelo sistema familiar a fim de assegurar a continuidade do cuidado e da vida, assume diferentes significados e dimensões no domicílio, a depender, sobretudo, da perspectiva adotada pelos indivíduos que integram o sistema familiar, para definirem suas vidas e seus projetos, dos valores, das metas e sentimentos partilhados, que mobilizam suas atitudes e ações, da capacidade de transformação cognitivoafetiva para acolherem e ajustarem-se às mudanças definitivas, que por sua vez influenciam as escolhas determinantes da forma como vivem o presente e seguem suas vidas.

A forma como o sistema familiar organiza suas interações para viver com as circunstâncias de vida definitivas geradas pela situação de ter uma criança com necessidades especiais de saúde, que dependerá continuamente do cuidado dos pais como meio de manter a vida, é simbolizado na experiência interacional da família por dois fenômenos: PRESERVANDO A VIDA DA CRIANÇA, que contém as categorias ESTABELECENDO COMO META INEGOCIÁVEL; LUTANDO CONTRA A CIRCUNSTÂNCIA DE VIDA; CRIANDO UM MUNDO DE PRIVAÇÃO VITIMIZANDO O FILHO E A SI MESMA; VIVENDO CADA UM POR SI; VIVENDO O ESGOTAMENTO; ESFORÇANDO-SE PARA AGUENTAR; e TENDO A VIDA IMERSA NO SOFRIMENTO; e PRESERVANDO A VIDA FAMILIAR, que contém as categorias: INTEGRANDO O CUIDADO À VIDA FAMILIAR; INCORPORANDO AS MUDANÇAS DEFINITIVAS; CUIDANDO UM DO OUTRO; CUIDANDO DO ESPAÇO FAMILIAR; REDIMENSIONANDO O PROJETO DE VIDA FAMILIAR; CRIANDO UM MUNDO PARTILHADO; CRIANDO UM AMBIENTE DE CURA E PERSEVERANDO, representativos das diferentes formas de viver essa experiência, as quais refletem os movimentos do sistema familiar e os padrões interacionais de organização.

Os padrões organizacionais, representados pelos fenômenos PRESERVANDO A VIDA DA CRIANCCA E PRESERVANDO A VIDA FAMILIAR, refletem o nível de fragmentação e de coesão do sistema familiar, representativos do comprometimento do sistema familiar e dos 
movimentos que evidenciam a capacidade para lidar e assumir o controle da situação, com maior ou menor grau de renuncia às funções vitais do sistema familiar, de proteção, socialização e apoio mútuo, para a manutenção de seu sentido de continuidade.

\section{PRESERVANDO A VIDA DA CRIANCQA}

É a forma como o sistema familiar se organiza tendo com foco PRESERVAR A VIDA DA CRIANCCA. Preservar a vida da criança é uma ação legítima da família. Cuidar do filho, zelando pela vida e protegendo-o, independente de suas condições e pelo tempo que for preciso não é visto como uma opção, mas sim como um dever dos pais, ação esta permeada de componentes emocionais e morais.

Entretanto, estabelecer como uma meta única PRESERVAR A VIDA DA CRIANCCA reflete um tipo de organização que coloca a vida familiar em risco. Assumir a função exclusiva de PRESERVAR A VIDA DA CRIANÇA implica em renunciar a todas as outras funções vitais do sistema familiar.

A centralização e o contínuo movimento PRESERVANDO A VIDA DA CRIANCA, em detrimento da vida individual e da vida familiar, impõem intensas restrições, privações e sacrifícios a todos os indivíduos que integram o sistema familiar.

Esse movimento também evidencia elementos da história de vida familiar, como carência de recursos adaptativos, de sentimentos de lealdade e de pertencimento, de compromisso e de interdependência para ativar sistemas de apoio. Também reflete a cultura de cuidado especializado e a reprodução do padrão de organização temporal das ações, incorporados no processo de transição do hospital para casa. Representa o conflito entre a cultura técnica e a cultura familiar. Reflete, sobretudo, a dificuldade de assimilação da situação e da condição de vida individual e familiar gerada 
pela doença e a dependência tecnológica da criança, em sua complexidade e totalidade.

PRESERVANDO A VIDA DA CRIANÇA, como padrão único e inegociável, quase sempre, é reflexo de uma decisão que ocorre por via da perspectiva materna e é imposta ao sistema familiar. Ao decidir preservar a vida da criança e, para tanto, sacrificar a própria vida e a vida familiar, a mãe tem como foco os riscos, as limitações, as perdas e os vazios gerados pela condição de ter uma criança com necessidades especiais de cuidado de saúde, o que envolve, tanto a não aceitação da condição de vida, quanto a projeção de expectativas catastróficas para o futuro.

Desse modo, PRESERVAR A VIDA DA CRIANCCA passa a ser a opção de vida materna. Esse movimento de entrega e sacrifício pessoal é acompanhando do sentimento de renúncia. Ao mesmo tempo em que assume essa função e a responsabilidade incondicional, a mãe ressente-se por ter abandonado sua própria vida, por não estar cumprindo com as demais funções e pela sensação de que os outros indivíduos também não estão desempenhando os deveres e as obrigações que lhes cabem dentro do sistema familiar.

Esse padrão reflete a rigidez do sistema familiar, a intensa centralização no movimento PRESERVANDO A VIDA DA CRIANÇA e consequente privação à vida individual e familiar - CRIANDO UM MUNDO DE PRIVAÇÃO - que não permite espaço para os esforços de conciliação entre as complexas demandas e os escassos recursos e nem para pensar nas consequências, em longo prazo, que este estado de desequilíbrio, quando mantido de forma constante, possa acarretar para a unidade familiar.

Esse padrão de intensos sacrifícios para preservar a vida da criança e de privação pode ser um padrão transitório, ou seja, um estágio inicial de ajustamento à condição de vida da criança e da família, como também pode ser um padrão constante e, nesse caso, reflete a inabilidade do sistema familiar em trabalhar em conjunto de forma a atribuir significados efetivos, 
que permitam integrar as mudanças, definir seus projetos individuais e coletivos e prosseguir sua trajetória de vida.

\section{ESTABELECENDO COMO META INEGOCIÁVEL}

A meta de cuidar exclusivamente do filho doente é uma opção de vida materna, que pode ou não ter a concordância dos demais membros da família e a consequente colaboração ou conflito nas relações familiares.

Ao estabelecer como meta inegociável, a mãe age impondo o cuidado da criança com necessidades especiais de saúde como uma ação exclusiva e contínua para si mesma e ao sistema familiar. Quando não encontra colaboração por parte dos demais membros da família, por não compartilharem da mesma perspectiva de vida, a mãe acaba assumindo para si e sozinha as obrigações e as responsabilidades pelo cuidado, acompanhada de uma carga física e emocional difícil de suportar.

Esse padrão de comportamento materno de imposição e privação é mobilizado por crenças sobre o cuidado e sobre seu dever de mãe: acreditando que é seu dever; acreditando que se não tiver afeto pelo filho, ninguém terá; acreditando que é a única que sabe cuidar; e acreditando que o filho doente, que sofre, é o único que precisa de cuidado.

Ao impor o cuidado, a mãe estabelece as regras de conduta acompanhadas de cobranças e de exigências para que os outros indivíduos que fazem parte da família se adéquem à sua perspectiva sem, no entanto, conseguir abrir espaço para tal ação.

A habilidade para negociar papéis e expectativas mútuas é comprometida nesse tipo de organização. A discordância constante entre os membros da família conduz ao afastamento e ações isoladas dentro do sistema familiar. 
A determinação de que cuidar do filho com necessidades especiais é seu dever, faz que a mãe assuma para si a responsabilidade e a carga integral do cuidado, que se percebe vivendo em função do filho com necessidades especiais: procurando fazer tudo pelo filho e estabelecendo vigília constante. Ao focalizar o risco de vida da criança, a mãe acredita que sua presença contínua junto ao filho é uma forma de prevenir danos pessoais, um meio de não se sentir culpada ou ter remorso no futuro. É como se a mãe não aceitasse o risco e ao mesmo tempo estivesse se preparando para a morte do filho.

[...] Bom, eu... penso que se eu não cuido, não tem quem cuida, então acho que foi isso que... como eu sou mãe e eu fiz...eu tenho agora que me virar né? Então foi isso que... que me fez cuidar dela, se eu não tiver afeto quem vai ter... eles (pai/avó) convivem, mas não sabem... se ela fizer alguma coisa... não sabem o que é, e eu sei. Então fico aqui dentro só cuidando dela (filha), por que o que eu quero eu não posso, até ela (filha) ficar bem... eu não posso nem ficar doente.[...] (Mãe, família 2)

[...] "eu não sei ele (esposo), mas eu, eu quero que eles (filhos) fiquem bem só isso, sabe que o tempo que eles viverem, porque eles (médicos) falam assim que não tem cura, e que pode ser que eles (filhos) morram, mais eu quero que assim o tempo que eles viverem eles tenham o melhor de mim, então hoje eu só me vejo como mãe" [...] (Mãe, família 7)

Ao manter o foco do pensamento nos riscos e na incerteza, a mãe segue vivendo em estado de medo constante. O futuro é visto como ameaçador e torna-se foco de sua preocupação. O risco de vida da criança consome os pensamentos maternos e a aprisiona na relação de cuidado com o filho. Enquanto mantém o pensamento no risco e na incerteza quanto ao futuro, a mãe vive uma série de medos, que reforçam as ações de vigília e aumentam a sensação de sobrecarga materna: tendo medo de dormir e tendo medo de sair de casa.

"[...] eu cuido dela assim com muito amor, com muito carinho, por que eu não sei até quando eu vou ter ela (filha), então eu tento fazer de tudo assim, por ela entendeu? para depois não ter remorso, não sei! [...] eu não sinto confiança de deixar ela com ninguém, nem com o pai dela, não sei, isso é coisa de mãe, por 
que ah eu fico tão preocupada, para mim eu que tenho que estar fazendo as coisas para ela entendeu? até quando eu vou no mercado assim, eu fico meia...agoniada assim sabe?, para fazer as coisas tudo rápido, assim sabe?, para não demorar e chegar logo em casa, antes quando eu fazia compra eu demora muito no mercado, hoje em dia não, não olho nem preço das coisas sabe, já vou colocando no carrinho, para vir logo para casa, para ficar logo com ela, para ver se ela esta bem, essas coisas assim, se o telefone toca, o celular, e eu estou no mercado meu coração já dispara, por que já fico imaginando uma notícia ruim, sabe? Essas coisas assim... é... uma coisa assim que você fica meia.... com medo sabe? Não sei...se é pelo fato de você achar que vai receber um dia uma notícia ruim, então... e você não quer receber! e você fica pânico, eu fico![...] (Mãe, família 3)

A incerteza quanto ao tempo que terá que manter a força e a saúde para cuidar do filho, também é fonte de preocupação e medo: tendo medo de ficar doente e de não conseguir cuidar. Entretanto, apesar dessa ser uma preocupação constante, cuidar de si mesma é uma ação negligenciada, seja pela ausência de tempo, que é consumido pelas demandas constantes de cuidado da criança, ou mesmo de vontade.

No entanto, ao acreditar que o filho com necessidades especiais é o único que precisa de cuidado, a mãe age deixando de cuidar de si mesma e dos outros e direcionando os recursos prioritários para a criança. Tais ações potencializam as restrições e privações vividas pelos outros indivíduos que compõem a família, que passam a viver com "o que sobra". Muitas vezes o que sobra é o vazio na casa e na vida familiar.

[...] "Eu não tenho tempo de cuidar de mim, eu não tenho tempo sabe? O importante é que eu estou cuidando dela (filha), ate agora eu consegui cuidar dela, mas assim, eu já não cuido, eu vou ser sincera com você, eu já não cuido dela como eu cuidava antigamente, com aquela força" [...] (Mãe, família 7)

[...] "o que mais mudou assim, na vida do P.(filho saudável), por exemplo, era que antes eu tinha mais tempo para ele, quando o J. quando a $\mathrm{A}$. nasceu eu não tive tempo mais, nenhum, porque a gente acaba priorizando aquele que está mais precisando, então tipo assim, se você vê que está bem, se você vê que esta brincando, você vê que está comendo, se você vê que está estudando, você fala 'eu vou cuidar desse, que eu vejo que precisa mais de mim', então foi aquela..., eu acabei priorizando mais, por que eles são mais sofridos" [...] (Mãe, família 6) 
[...] "não pode deixar faltar as cosias da S.(filha doente)... por que as coisas dela é em primeiro lugar, né?o que sobrar a gente se vira, se tiver que comer arroz com feijão, a gente come, mas as coisas dela não pode falar, né?, Jamais nós vamos deixar faltar as coisas dela para né, levar eles para sair. As vezes eles (outros filhos) sentem, choram, ficam triste... já faz tempo que eles não passeiam" [...] (Mãe, família 3)

Esse vazio gera uma atmosfera de angústia e tristeza e que é sentida por todos. Quando o sistema familiar é composto por outras crianças, estas se sentem excluídas da relação com a mãe e, por vezes, da relação com ambos os pais, uma vez que são privadas da proteção, do carinho, da atenção e das atividades de diversão e de socialização que faziam parte de sua vida cotidiana. Isso coloca o desenvolvimento das crianças saudáveis que integram o sistema familiar em risco concreto, visto que são privadas dos referenciais simbólicos para organizarem suas condutas e desenvolverem seus autoconceitos, como preparo para a vida adulta.

Enquanto o foco permanecer em PRESERVAR A VIDA DA CRIANCAA, há o comprometimento do sistema familiar, como uma unidade de cuidados, o que gera uma experiência de cuidar e ao mesmo tempo serem privados do cuidado.

As privações impostas à vida familiar são fontes de sofrimento para todos os indivíduos. No entanto, a interpretação de que a criança doente é quem é vulnerável e está sofrendo não permite espaço para que os demais indivíduos expressem seu próprio sofrimento e ou sintam-se fragilizados.

Criar um espaço para a expressão de sentimentos e comunicação aberta é também uma ação negligenciada nas relações familiares dentro desse padrão rígido de organização e que, portanto, não permite ações de cuidado mútuo.

A crença da mãe de que é a única que sabe cuidar é reflexo de uma construção histórica e social acerca do lugar e do papel da mulher e que é incorporada no universo simbólico do sistema familiar. No entanto, essa situação é ressaltada e fortalecida pela experiência vivida durante o 
processo de assimilação da condição da criança e da cultura do cuidado, vivido no tempo de hospitalização, onde o espaço para o exercício do papel masculino de pai e de cuidador é limitado.

As instituições que tem como função preparar a família para viver com a condição de doença priorizam a presença da mulher/mãe e ao mesmo tempo impõem barreiras para a presença do pai e para a manutenção do convívio familiar. Assim, quando os indivíduos não possuem habilidades para negociar a inclusão dos demais membros da família, acabam vivendo a experiência de forma fragmentada e isso, por sua vez, conduz às quebras e barreiras nas relações familiares no âmbito doméstico.

Dessa forma, a mãe vê o pai/marido, bem como os outros integrantes que fazem parte de seu convívio, como se não estivessem preparados para participar do cuidado no domicílio ou mesmo compreender a situação, por não terem tido a mesma vivência que a sua, durante o tempo de hospitalização e por não terem participado das decisões relacionadas à vida da criança. Diante de tal constatação, a mãe também questiona o sofrimento vivido dentro da família, evidenciando a sensação de que está sofrendo sozinha.

Ao acreditar que é a única que sabe cuidar, age desqualificando o cuidado dos outros, culpando o marido/pai por não ter vivido e sofrido tudo o que viveu no hospital e não aceitando visões e práticas divergentes daquilo que acredita ser o certo, o que faz que a mãe não consiga aceitar a ajuda disponível e ainda afaste as pessoas que são, constantemente, desmotivadas a continuar na tentativa de querer partilhar do cuidado ou mostrar diferentes caminhos para a vivência da situação.

[...] "ele (esposo) só levanta de manhã e vai trabalhar, daí chega lá... tudo bem, ele trabalha, todo trabalho é pesado, mas assim, ele (esposo) não escuta o que os médicos falam, não esta na hora que tipo... o J. (filho) teve uma parada, quem estava na hora era eu, todas as coisas ruins que acontecem no hospital sou eu que estou, o sofrimento é igual? [..] (Mãe, família 6)

[...] Ele (pai) foge, até então, com o problema da E. (filha), ele (pai) finge, agora eu estou muito estressada, estou nervosa, ontem eu comecei a chorar, chorar, chorar, e do nada a E. (filha) começou a 
chorar, sabe tipo, estava com dor uma coisa assim, e eu fiquei nervosa, e dai que ele (pai) foi lá e falou 'S. vai para lá', ai eu sai de perto, que ele (pai) foi cuidar dela (filha), e ficou lá um pouco com ela (filha) mais ele (pai) não tem esse interesse, de dizer assim 'minha filha é especial, eu vou cuidar da minha filha, eu quero saber da minha filha, eu quero saber o porquê disso'[...] (Mãe, família 7)

Ao determinar o cuidado do filho doente como opção e, portanto, viver em função do filho doente, a mãe tem consciência que não é apenas a vida da criança que está em risco, mas, sobretudo, que a vida familiar também é colocada.

A parceria desenvolvida dentro do sistema familiar é um processo que tem a ver com as perspectivas adotadas para definir a situação, quando as visões do pai, de outros membros da família e de pessoas significativas, e suas consequentes ações não se adéquam à perspectiva adotada pela mãe. Ela se vê como se estivesse sozinha e passa a agir isoladamente, criando barreiras simbólicas que a conectam com a criança doente e ao mesmo tempo fragmentam o sistema familiar, afastando as pessoas de seu convívio e apegando-se mais ao filho doente.

[...]"tem as outras crianças também né?, mas eu não sei se é devido a situação dela, então eu me apeguei muito assim com ela(filha doente) [...] (Mãe, família 3)

[...] Não deixava a pessoa falar, antes da pessoa falar eu já falava não quero crítica, se quiser me dar um apoio me da a mão ou então não faz nada, se não quiser ficar do meu lado e me apoiar se afasta e isso foi acontecendo... as pessoas foram se afastando...é como se eu estivesse sem ninguém, é só eu, eles (filhos), que ai eu fico até com medo, porque daí eu fico pensando assim... 'já pensou se não tem o V (marido/pai)?' Sabe assim, é que eu não falo para ele (marido), que eu não quero dar ousadia... falo que 'eu não estou nem ai pra você', mas assim..., porque eu acho que se eu não tivesse ele (marido), acho que eu morreria, eu morro, porque eu não vou conseguir, porque ele (marido) pelo menos, ele chega, ele não é muito assim... sabe?... igual aos pais que eu vejo, que cuidam também... ele (esposo) não, já é mais assim...ele cuida se eu mandar, se eu ficar brigando, fazendo aquele escarcéu, mas não por aquele amor, aquela coisa sabe?" (Mãe, família 6)

O comportamento materno influencia o comportamento dos demais indivíduos e quando estes, por sua vez, não têm habilidade ou mesmo 
disposição para tentar negociar e romper com esse ciclo negativo, podem acabar por desistirem uns dos outros e decidirem seguir vivendo cada um por si, o que evidencia a fragmentação do sistema familiar e o isolamento entre os indivíduos dentro do ambiente doméstico.

Quando isso ocorre, a mãe se percebe tendo medo de ficar sozinha, especialmente quando a cooperação começa a ceder lugar ao conflito e ao perceber o distanciamento dos indivíduos de seu convívio e ao mesmo tempo a sensação de incapacidade de reinvestir esforços na vida e nas relações familiares, já desgastadas e imersas no sofrimento.

Com isso, a mãe sente-se abandonada pela própria família e interpreta o afastamento como desprezo, rejeição e ausência de amor nas relações familiares. Os esforços maternos são direcionados a lutar contra a circunstância de vida.

\section{LUTANDO CONTRA A CIRCUNSTÂNCIA DE VIDA}

Os significados que a mãe atribui a si mesma e a situação que enfrenta resultam de uma série de projeções simbólicas, que criam definições, pensamentos, expectativas e ações, que negam e geram desconexão, manifesta em um contínuo de ações, as quais determinam o movimento LUTANDO CONTRA A CIRCUNSTÂNCIA DE VIDA.

LUTANDO CONTRA A CIRCUNSTÂNCIA DE VIDA é o movimento materno diante da dificuldade de aceitar e internalizar as suas circunstâncias de vida e envolve as linhas de ações: lutando contra a doença; não aceitando os limites da criança e seus próprios, cuidando continuamente, projetando expectativas que não se ajustam à realidade e não vendo resultado.

Lutar contra a doença é uma ação secundária a não aceitação das condições de vida da criança e reflete a dificuldade materna em aceitar sua identidade e seu papel de mãe de uma criança com necessidades especiais 
de cuidado de saúde. O "sonho" e o desejo de que o filho seja uma criança normal, impulsiona a mãe a lutar contra.

A mãe acredita que, ao lutar contra, não aceitando as limitações da criança, pode influenciar na cura da doença. Nesse movimento de lutar contra a doença, a mãe age não aceitando os limites da criança, a dependência tecnológica e nem os seus próprios limites físicos e emocionais.

[...] "Minha filha está tentando falar, eu já consegui tirar uma foto da E. (filha) em pé, entendeu?, ela firmando nas minhas pernas assim eu levantei a mão, e ela ficou em pé certinho, então assim..., eu luto, luto bastante igual você viu, você me pegou em um dia muito nervosa igual na quinta-feira (referindo-se a visita anterior). Eu acho assim, por eu ser assim, sabe? não aceitar a filha que você tem, sabe?, eu não aceito minha filha ficar parada, eu creio que a minha filha vai ser... eu tenho esse sonho, de ser normal" [...] (Mãe, família7).

A mãe mantém uma "corrida contra o tempo" cuidando continuamente como uma forma de tentar impedir a progressão da doença e de influenciar na melhora da criança, tendo como foco o que quer para si como mãe e não as necessidades da criança.

O ter como foco o que quer como mãe e, consequentemente, a não aceitação das condições de vida da criança e da família, a mãe mantém uma "esperança ingênua", pouco efetiva para o enfrentamento, diante da projeção de expectativas que não se ajustam à realidade.

Ao seguir projetando de expectativas que não se ajustam à realidade, como querer ver o filho andar, falar, comer, não permite que a mãe perceba os benefícios de seus cuidados, não vendo resultado.

[...] "tem horas, tem dias que... você faz, faz, faz e... quando põe na ponta do lápis assim... que você chega no médico, parece que você não fez nada sabe? E você olha assim... vê aquele infinito de coisas para fazer, que não dão em nada também, é o mesmo que você não estiver fazendo nada, é o mesmo que estiver parado com eles (filhos) deitados na cama...eu, pelo menos da minha parte, eu tento fazer de conta que o futuro não existe, sabe? Eu tento...tipo...hoje assim eu olho e não vejo mais nada, hoje eu vou fazer de tudo para melhorar, mas eu não faço mais planos porque 
foi cinco anos de planos sabe? Foi cinco anos eu passando em fono, e... ela (filha) nunca comeu (choro, voz embargada)" [...] (Mãe, família 7)

A mãe espera que seus esforços sejam premiados com os resultados projetados e, nesse caso, com uma melhora na condição da criança. Diante disso, passa a viver um ciclo de intenso investimento de esforços - $\underline{\text { cuidando }}$ continuamente e intensamente - e ausência de compensação, derivada da percepção que suas ações não têm efeito. Essa ausência de percepção de retorno ou efeito do cuidado é vivida como uma experiência frustrante e desgastante para a mãe, que não percebe o valor de suas ações e de si mesma, diante da função que desempenha.

Esse movimento LUTANDO CONTRA A CIRCUNSTÂNCIA DE VIDA se torna fechado, cíclico e tem como consequências CRIANDO UM MUNDO DE PRIVAÇÃO, VIVENDO O ESGOTAMENTO e ESFORÇANDO-SE PARA AGUENTAR o que determina o contínuo de intenso sofrimento, TENDO A VIDA IMERSA NO SOFRIMENTO expresso nas ações VITIMIZANDO O FILHO E A SI MESMA e VIVENDO CADA UM POR SI.

Esse contínuo de intenso sofrimento é permeado pelo desespero, alternado entre a imposição para agir desesperadamente pela criança, ir além dos limites, lutando contra a doença e, ao mesmo tempo, desesperança, tanto em relação às expectativas de vida projetas para a criança (desajustadas), quanto em relação à vida pessoal e familiar desamparada diante do movimento CRIANDO UM MUNDO DE PRIVAÇÃO.

A dúvida é constante. Ao mesmo tempo em que a mãe sente-se capaz de prover o melhor cuidado para o filho, também sente que não está fazendo nada pelo filho e, em relação ao tempo, terá que manter a força e a saúde para continuar cuidando, diante do intenso desgaste que esse tipo de organização gera em si mesma. A incerteza e o desespero interrompem o fluxo de vida familiar, o convívio partilhado se torna raro e a casa é vista como um ambiente de privação e de intenso sofrimento. 


\section{CRIANDO UM MUNDO DE PRIVAÇÃO}

As interpretações da situação, as metas estabelecidas e as barreiras simbólicas criadas, como ações que integram o comportamento materno, e que por sua vez não é transformado pelas ações dos demais indivíduos que compõem o sistema familiar, são refletidas simbolicamente no processo CRIANDO UM MUNDO DE PRIVAÇÃO.

Ao agir criando barreiras para a conexão, a mãe é conduzida ao sentimento de solidão e de confinamento, o que traz em si intenso sofrimento e a vivência do esgotamento de forças diante da ausência de percepção e busca de apoio.

O mundo de privação criado pelo sistema familiar como consequência de suas ações desagregadoras reflete e devolve essas ações como ineficiência, incapacidade para lidar com a situação e de prevenir consequências negativas, inefetividade diante dos significados e expectativas projetadas, além de ausência de poder de autodirecionamento.

Ao criar um mundo de privação, o ambiente familiar é transformado em um contexto de carência afetiva, onde todos se sentem sendo privados do convívio familiar, e sendo privados do cuidado, como forma de proteção psicossocial para todos os indivíduos que integram o sistema familiar.

Ao criar um mundo de privação, dado as barreiras comunicacionais geradas no âmbito doméstico e para a conexão com o ambiente social, o sistema familiar sofre os efeitos negativos da sobrecarga física e emocional, das restrições econômicas, da ausência de informações e da incomunicabilidade social, o que por sua vez dificulta transformações na vida familiar, diante de uma situação de intensas privações e de ausência ações que gerem forças e recursos, que podem resultar na vivência de esgotamento. 


\section{VIVENDO O ESGOTAMENTO}

O movimento cíclico e fechado de lutar contra as circunstâncias de vida e criar um mundo de privação gera a vivência de esgotamento na vida familiar, no âmbito financeiro, relacional e moral, face às ações devolvidas como inefetividade e contínua ausência de visualização de opções para a resolução dos problemas.

As intensas privações e sacrifícios impostos à vida familiar, a fragmentação do sistema familiar e as contínuas demandas de cuidado da criança, adicionada ao ciclo de cobranças que ordenam os relacionamentos familiares, gera a sensação de exaustão física e metal. A mãe, por sua vez, devido à carga que assume e à ausência de limites no movimento de lutar contra a doença, tem o potencial de sofrer mais diante da exaustão e se vê perdendo a força com o tempo.

O tempo, recurso fundamental para a preservação do espaço relacional do sistema familiar, é consumido nesse tipo de organização familiar em torno das ações de cuidado contínuas, que não permitem espaço para o descanso, para o lazer, e para o diálogo. A mãe, ao assumir o cuidado contínuo da criança como sua função exclusiva dentro do sistema familiar, se vê não tendo tempo para mais nada e não vendo mais nada na vida.

A intensa dedicação materna ao cuidado da criança não permite tempo para cuidar de si mesma e dos demais; não permite tempo para o diálogo e para o convívio social, o que, por sua vez, faz que a mãe mantenha-se aprisionada ao cuidado do filho doente e não consiga visualizar opções para direcionamento de sua própria vida.

O ciclo contínuo de sobrecarga e a criação de barreiras para a conexão, adicionada da dificuldade de mobilização de sistemas de apoio, gera a percepção diminuindo o apoio e esgotando os recursos com o tempo, o que potencializa o sentimento de incapacidade para lidar com a situação. 
[...] "precisar das coisas sempre a gente precisa né?, a gente que é pobre né? precisa de ajuda financeira para as coisas que não podem falatar, mas é difícil assim, a ajuda. Então, eu nem fico correndo atrás assim muito, não sou muito de pedir, sabe?" [...] (Mãe, família 3)

[...] "Sabe o que é Aline, eu sempre bato nessa tecla, a ajuda de uma família para uma pessoa é fundamental, eu não tenho uma ajuda de ninguém, que nem eu estava falando para minha cunhada, eu tenho que aceitar isso porque ninguém bate na minha porta e fala 'vim pegar a E.(filha) para passear' porque ela não é uma criança normal, eu tenho que aceitar isso. Então assim, ajuda familiar, a ajuda do companheiro, levanta a auto-estima, o que eu sempre digo é isso, o minha auto-estima...sempre esta lá em baixo, sabe? Não tenho ninguém, igual você vê, minha casa está vazia, só eu dentro de casa sabe?[...] (Mãe, família 7)

Os problemas são potencializados diante do isolamento entre os indivíduos e suas fontes de apoio e de vínculos desgastados pelo excesso de exigências, restrições e conflitos na vida familiar. Desse modo, os esforços são direcionados ao aguentar, diante da percepção TENDO A VIDA IMERSA NO SOFRIMENTO.

Desse modo, TENDO A VIDA IMERSA NO SOFRIMENTO é reflexo das dimensões que o sofrimento assume com os vazios gerados na vida familiar e ausência de perspectivas para o futuro expressas simbolicamente nas ações VITIMIZANDO O FILHO E A SI MESMA e VIVENDO CADA UM POR SI.

\section{VITIMIZANDO O FILHO E A SI MESMA}

Diante da vivência de esgotamento de forças e ausência de apoio, a mãe se torna vítima de suas próprias ações e das ações dos outros. Assume a posição de vítima dentro do sistema familiar e, portanto, age VITIMIZANDO O FILHO E A SI MESMA.

Sofrer pela condição de vida da criança é secundário à forma como os pais interpretam a situação e reflete a dificuldade em aceitar e em incorporar essa condição circunstancial de serem pais e os limites para o exercício da 
paternidade, pois projetam na criança suas próprias angústias e frustrações, diante de expectativas que não podem ser realizadas.

O sofrimento pela condição de vida da criança pode atingir todos os indivíduos que fazem parte da vida familiar. A intensidade que o sofrimento é vivido, a tolerância e as formas de manifestação variam dentro do sistema familiar. O que reflete o grau de impacto e domínio dos indivíduos sobre o próprio sofrimento.

A mãe tem o potencial de imergir no sofrimento, diante da carga que assume, do padrão de comportamento que adota, frente à vivência de esgotamento e da não aceitação de sua condição de vida, VITIMIZANDO O FILHO E A SI MESMA. Ao fazer isso, a mãe tem o potencial de transformar o espaço familiar em um lugar de tristeza, dor e intenso sofrimento para todos os membros da família.

A mãe sofre por acreditar que o filho está sofrendo e, ao perceber-se sozinha, sofre por não ter com quem partilhar a carga do cuidado, sofre por ver que a vida do outros está seguindo e por ver sua própria vida parada no tempo, sem conseguir ver sentido e nem os meios que permitam o autodirecionamento, culpando os outros por seu próprio sofrimento VITIMIZANDO O FILHO E A SI MESMA.

A VITIMIZAÇÃO DO FILHO E DE SI MESMA é o meio utilizado pela mãe para expressar seu sofrimento diante da condição da criança e de sua própria condição de vida, devido à não aceitação que traz em si, à ambiguidade vivida pela mãe na relação de cuidado com o filho, a culpa por não ter tido um filho normal ou mesmo o arrependimento por ter tido um filho doente e o descontentamento por ter parado sua própria vida para cuidar do filho.

Vitimizar-se representa o conflito materno entre capacidade de doarse e de assumir o lugar que lhe pertence, dentro do sistema familiar, e a sensação de renúncia. Se, para estar junto ao filho, é preciso deixar o trabalho, ação que traz em si a renúncia e o sacrifício, voltar a trabalhar e 
delegar o cuidado do filho para outra pessoa da família também é fonte de sofrimento, pela sensação de estar renunciando a seu dever e papel de mãe.

VITIMIZANDO O FILHO E A SI MESMA é uma ação da mãe que manifesta sua visão negativista da situação, sua constante centralização nas limitações, na dificuldade de desprender-se das perdas do passado e conciliar-se com o presente, de forma a transformar-se para internalizar as mudanças definitivas que acompanham sua circunstância de vida. Ele reflete um estado de alienação materna e, por consequência, de todos os membros da família em relação ao presente que precisa ser apreendido e vivido.

Ao olhar para o passado, a mulher/mãe só consegue visualizar as perdas e, no presente, são as dificuldades, a ausência e o vazio que são ressaltados. Enquanto se preocupa com o futuro, frente às expectativas catastróficas projetas, em relação à vida da criança, sua própria e da família, não consegue viver o presente e não consegue visualizar direcionamento para a própria vida e para a vida familiar.

A VITIMIZAÇÃO DO FILHO E DE SI MESMA surge em função da perspectiva e do tipo de raciocínio empregado para definir sua própria situação fazendo comparações, lamentando as perdas e sofrendo com os vazios.

Ao pensar em si mesma, sua criança e sua família fazendo comparações as limitações, os déficits, as dificuldades, as ausências e a anormalidade são ressaltadas. Ao comparar o apoio que possuiu com o tipo de ajuda de outras famílias, o foco é apenas naquilo que falta para si mesma e a mãe se vê precisando de muito e não tendo nada.

Ao comparar o jeito que o marido cuida, o percebe não cuidando como os outros pais, o que a faz buscar um padrão ideal de cuidado, cobrar do marido/pai um comportamento igual ao dos outros pais e não aceitar aquilo que ele pode oferecer, dentro de suas características individuais. $\mathrm{O}$ que faz, por sua vez, que a mãe assuma para a si a responsabilidade e a 
carga do cuidado e afaste-se do convívio e, por consequência, sinta-se vítima.

Os recursos instrumentais para o cuidado e o acesso a serviços também são fontes de comparação e angústia: pensando que o filho não está recebendo tudo que precisa; pensando que não está fazendo sua parte e imaginando que está deixando o filho piorar. Sobretudo a mãe acredita que o filho está sofrendo, porque constantemente utiliza como parâmetro de comparação o padrão de normalidade de uma criança saudável. E, desse modo, sofre por sentir-se impotente e não conseguir aliviar o sofrimento do filho, diante das expectativas de melhora que projeta, de forma desarticulada da realidade de vida da criança.

[...] "você sabe que está sofrendo, e você finge que não está, sabe assim? Sabe quando você fala 'ah...ele...', mas você sabe que não é assim, você sabe que está sofrendo, porque você sabe que o normal não é desse jeito, não é estar ali dependente de oxigênio, até para respirar[...] as coisas que faltam para eles (filhos), o que falta para mim não é tão importante, se eles tivessem, uma comparação, se eles tivessem uma fisioterapia, três vezes por semana em casa como outras crianças têm, por exemplo, a parte pior é, como eu te falei, de você imaginar que eles (filhos doentes) estão ali, e está faltando alguma coisa, que você não está fazendo tudo que você pode, o que me causa mais sofrimento é isso... de as vezes você ter que contar moeda para poder comprar uma fralda, por exemplo, sabe assim? é esse o sofrimento maior, você imaginar que esta deixando eles (filhos) piorarem sem fazer nada, o que me causa mais sofrimento e de ver essa situação, de olhar assim, e saber que estão precisando de alguma coisa ainda..." (Mãe, família 6).

Outra forma de a mãe agir VITIMIZANDO O FILHO E A SI MESMA é lamentando as perdas. Ao lamentar as perdas, a mãe sofre pelas já passadas e antecipa outras, frente às suas expectativas catastróficas, pensando que o tempo de vida da criança está se esgotando e vendo que sua vida e a vida familiar está se acabando.

Ao focalizar as perdas passadas, a mãe age lamentando não ter 0 filho normal, o que evidencia a não aceitação de sua condição e de identidade materna, lamentando por perder as pessoas que antes faziam parte de seu convívio e com quem mantinha vínculos afetivos. 
Ao pensar sobre seu cotidiano, a mãe age lamentando por viver confinada ao ambiente doméstico cuidando do filho, o que revela a ambiguidade gerada pelas ações maternas, a dificuldade em aceitar as limitações inerentes à condição de viver com uma criança com necessidades especiais de saúde em casa e às privações geradas pelo movimento de preservar a vida da criança como meta única e inegociável.

Ao viver a solidão dentro de casa, age lamentando não ter o amor do marido e da família. Diante da renúncia para viver em função do filho doente age lamentando não ter liberdade, lamentando não poder trabalhar e sofrendo ao ter de pedir, o que reflete a dificuldade de incorporar os limites socioeconômicos, o status de dependência ou a interdependência, seja em relação ao homem ou mesmo em relação à família extensiva e à comunidade, como meios para ativar sistemas de apoio.

Diante da tristeza, da dor, do sofrimento e da privação gerados no ambiente doméstico, os sentimentos são direcionados à ausência daquilo que queria ter para si e para os outros sentindo falta de ver os filhos saudáveis felizes. Em relação à vida do casal sentindo falta de sair juntos, sentindo falta de conversar, sentindo falta de ter um tempo para o casal e sentindo falta do companheirismo do apoio, do estar junto olhando na mesma direção e da afetividade do marido. Diante de tantas privações e da perspectiva adotada, a mãe se percebe não podendo ser feliz.

[...] "a minha vida... é uma vida assim programada aos mesmos sentidos, não tem outro tipo de programação e a minha vida acabou assim... até então devidamente sabe? à saúde da minha filha, sabe?...não pela minha filha, não por ela, mas pela saúde da minha filha, a falta financeira, sabe? Por eu ter parado a minha vida, eu ter lutado tanto sempre sabe? E hoje minha vida parou, parou no tempo, não posso sair, não posso me divertir, nem na Igreja eu posso ir, nem tenho vontade de ir...eu não tive a minha vida normal como eu tinha antes, antes eu vivia e não sabia entendeu? Antes eu tinha ar livre e não sabia, tinha liberdade e não sabia, e agora em questão do nascimento da minha filha é que parou tudo, porque eu não posso trabalhar, eu não posso sabe? Não posso ir no mercado, não posso em uma loja sabe? Não posso ir ao centro, não posso nada mais, não posso ir numa farmácia, nada sabe? Se eu quiser um cosmético, alguma coisa, eu não posso entendeu? Porque tudo que eu for fazer eu tenho que estar com a minha filha, entendeu? Tudo que eu tiver que fazer eu tenho que estar com a minha filha, então parou nisso, 
parou nisso, minha vida não teve mais sentido, a única alegria que tenho Aline, a única que ainda me faz sorrir é o sorriso da minha filha, então assim é... essa é a única alegria, o única o sorriso que eu tenho da minha filha. Eu não tenho mais sentido de viver assim sabe?...eu queria que alguém falasse, 'olha $S$. você vai por esse caminho aqui, que você vai consegui chegar lá', porque eu não estou conseguindo distinguir a minha vida, não estou conseguindo direcionar a minha vida, não estou conseguindo sabe? Ser dona de mim é muito ruim você achar que você não é ninguém, eu to me achando assim, uma ninguém, antes eu era uma pessoa, agora eu sou outra. Sabe o que é você estar mal, e ninguém percebe que você existe, ninguém vem ter dar uma palavra de apoio? Eu falo que eu tive muitos sonhos, que eu sonhei muito, talvez se eu não tivesse sonhado nada disso teria acontecido. P. Que sonhos você tinha? ser feliz... ter paz. P. E você acha que isso não é possível? Não, porque eu nunca tive (choro). Queria uma mãe que me amasse, um marido que me amasse, uma criança saudável, só esses três, só, me fazia uma mulher muito feliz. São muitos anos de luta, são muitos anos de batalha, e não ter sucesso (choro) (Mãe, Família 7)

Sofrendo com os vazios representa a vida completamente devastada e imobilizada pela ausência de perspectivas efetivas que permitam aprender e viver o presente e manter a continuidade da vida. A desolação que surge ao se ter a vida imersa no sofrimento não permite a visualização de saída, de alternativas ou possibilidades e a mãe se vê não conseguindo mais pensar em si mesma e nos outros, pensando apenas que precisa cuidar do filho doente; não fazendo mais planos; planejar algo que não inclua o cuidado do filho doente é uma ação considerada impossível e mesmo inadmissível nas relações familiares, ao mesmo tempo em que a mãe não consegue fazer planos para si mesma, também não permite que os outros 0 façam ou partilhem suas ideias com o grupo familiar, acreditando que se deva pensar apenas na criança doente.

A mãe, ao contemplar o vazio de sua vida e seu profundo sofrimento, percebe-se não tendo mais sonhos. A mulher/mãe projetava seus sonhos a partir do trabalho, o sonho de ter uma vida melhor, de adquirir independência e valor fora do ambiente doméstico, o sonho de ser feliz, de ter uma casa própria. Os sonhos adquiriam vida graças ao trabalho, deixá-lo implica em renunciar aos sonhos. 
Diante da ausência de planos e sonhos, diante da solidão e da falta de apoio, a mãe vive a angústia constante não conseguindo direcionar a própria vida e não vendo sentido na vida. Vazio que a mantém reclusa em seu mundo de privação, em estado de medo e desânimo e sem confiança para investir nas possibilidades para a continuidade da vida.

Os vazios existenciais vivenciados pela mulher também expressam a imersão no sofrimento, vendo-se apenas como mãe e sentindo-se invisível.

A rigidez das barreiras estabelecidas entre a mãe e a criança doente, e entre si e sua própria realidade impedem a aproximação dos outros membros da família e impedem que a mãe focalize seu interesse e energia em outros aspectos e relacionamentos centrais para a manutenção da vida familiar e a satisfação com sua própria vida. Esse movimento da mãe de assumir para si toda a carga faz que encontre dificuldades para conciliar demandas pessoais e dos demais membros da família com os quais também tem um compromisso.

Vendo-se apenas como mãe representa a invasão da situação de ter uma criança com cuidados especiais na vida materna. O papel de mãe e sua identidade materna se sobrepõem a todos os outros: de mulher/esposa, de filha, de irmã, de trabalhadora, restringindo suas possibilidades de ser algo além de mãe-cuidadora.

[...] Então para mim hoje em dia eu só me vejo como mãe, eu não me vejo como outra coisa, porque não da tempo nem de ser irmã porque eu não tenho tempo nem de conversar com as minhas irmãs direito se elas não virem aqui; não da tempo de ser filha porque eu não consigo conversar com a minha mãe direito se ela não vir aqui, e quando vem, ela (mãe/avó) fica morrendo de pena de mim e eu fico com dó dela porque ela fica só 'ah minha filha' sabe?, daí eu fico com dó dela porque eu sei que assim através de mim ela (mãe) sofre também; mulher já não é, esposa já não é a mesma coisa, igual, a gente vive juntos, porque a gente achou que tinha que ser assim, melhor... tanto ele (esposo) quanto eu, a gente sabe que o melhor não é se separar, o melhor é continuar assim... melhor para eles (filhos), e melhor para tudo, mas assim como era antes acho que nunca mais vai ser sabe assim?[...] (Mãe, família 6) 
Ao ver-se apenas como mãe e ao atuar apenas como mãe, por sua vez, gera instabilidade na relação conjugal, cobranças por parte do esposo, além de dificuldade no relacionamento com os outros filhos e, igualmente, cobranças por parte dos demais filhos. As cobranças direcionadas à mãe, por parte dos demais membros da família, especialmente do esposo, são percebidos pela mãe como estressores adicionais, para os quais não vê meios de lidar e se vê ainda mais exigida e sobrecarregada. Com isso também direciona cobranças aos demais membros da família e a si mesma, tendo como justificativa o fato de ter de se dedicar mais ao filho doente. Esse ciclo de autocobranças restringe cada vez mais as possibilidades de convívio dentro de casa.

Dessa maneira, o viver dentro de casa se torna uma experiência de intenso sofrimento, quando a mãe se vê sozinha, aprisionada em casa e ao cuidado do filho, sem tempo para agir e ser alguém além de mãe, que se percebe sentindo-se invisível.

A mulher/mãe vê sua vida como "parada no tempo" e não consegue se movimentar por conta do esgotamento dos recursos, pela percepção de ausência de apoio dentro de casa e um sentido que possibilite 0 direcionamento da própria vida. A sensação de que sua vida acabou e que os outros estão seguindo em frente, deixando-a relegada ao abandono e ao confinamento doméstico representa a forma de expressão do sofrimento materno, como vazio existencial sentindo-se invisível.

A sobrecarga e o sofrimento materno resultam de um conjunto de fatores cognitivos e interacionais. As indicações que a mãe faz para si mesma em direção ao self, assumindo para si a responsabilidade integral pelo cuidado, vendo-se apenas como mãe e sentindo-se invisível, ou mesmo, não aceitando a condição de vida, mas tendo que aguentá-la, vendo apenas aspectos negativos em sua vida referem-se à dificuldade da mãe em reorganizar-se cognitivamente, de modo a transformar-se para internalizar sua realidade de vida. 


\section{VIVENDO CADA UM POR SI}

Vivendo cada um por si expressa a desintegração do sistema familiar frente à ausência de tempo e perspectivas de vida partilhadas. A ausência de conciliação com o presente e sua condição de vida não permitem o empreendimento de ações articuladas à resolução dos problemas que se apresentam e isso resulta em constantes conflitos de perspectivas e em desintegração entre os indivíduos que compõem o sistema familiar, que passam a agir VIVENDO CADA UM POR SI.

A perspectiva materna que orienta as definições e ações na situação, nem sempre é partilhada pelos demais e, desse modo, tendo conflitos de perspectivas gera valores, pensamentos, visões, ações e metas desintegradas dentro do sistema familiar, o que, por sua vez, leva os integrantes a projetos de vida individualizados. Enquanto que a mãe estabelece como meta lutar contra a circunstância de vida da criança, o pai estabelece como meta voltar a estudar e melhorar suas condições de trabalho, o que, por sua vez, não é aceito na perspectiva materna e conduz a conflitos e desintegração das ações familiares.

[...] "não tem tempo, não dá para sair, não sai mais, não conversa mais, quando conversa é tudo sobre doença, porque é muita coisa... e o problema é mais meu, porque ele (esposo/pai) consegue ficar calmo, tranquilo, mais eu não consigo, para mim, eu só penso neles, daí ele (esposo) vem falar 'ai eu vou fazer isso, vou fazer aquilo', e eu já fico 'ah mais e eles (filhos)? Tem que pensar neles'. Então, ai a gente já briga, porque tipo assim... ele (esposo) consegue ver a outra parte, eu não consigo ver mais, para mim a única coisa que eu vejo é meus filhos, é a única coisa que eu vejo, pra mim não tem essa de falar, 'ah vou estudar, para fazer uma faculdade, fazer isso', eu não vejo isso, porque para mim isso não é necessário agora, para mim eu tenho que cuidar deles, se eu estudar e pagar duzentos reais, vai faltar para eles, porque a gente já ganha pouco, já é tudo pouco, se eu for pensar em outra coisa para mim falta para eles e ai? Como que vai ficar? Então minha cabeça é só para isso! eu tenho certeza que o problema é mais comigo também, porque eu não passo em um psicólogo, primeiro porque assim, todo mundo fala, eu já peguei até os encaminhamentos, mas não dá tempo, eu vou ir para psicólogo, nem para isso eu consigo tempo, não dá! Então eu fico assim, exigindo demais dele (esposo), as vezes nem é demais, mas eu quero, eu não entendo o lado dele (esposo)[...] (Mãe, família 6)

[...] "Penso... não admito me separar do pai da E. (filha) ele viver a vida dele de solteiro, e eu continuar sofrendo com a minha filha 
sozinha, porque ele pediu a criança, eu não estou dizendo que eu não quis, eu quis também lógico, mas eu não me imaginava ser mãe, é o que eu sempre falei antes, não imagina ser mãe, sempre falava 'eu amo criança, mais não quero ser mãe', devido a ele (esposo/pai), por eu antes amá-lo, querer fazer, querer agradá-lo, fiz tratamento para ter a minha filha, mas antes eu se não tivesse feito, porque foi um pedido dele não meu, eu quis dar para ele (esposo/pai) uma coisa que eu imaginava... que ele seria um pai de verdade, ele é um pai carinhoso, mas não é um pai responsável, tudo para ele (pai) é trabalhar, tudo 'eu tenho que trabalhar' [...] (Mãe, família 7)

É como se estivessem vivendo em mundos diferentes. Enquanto que a mãe mergulha no mundo de privação e sente-se aprisionada na relação de cuidado com o filho doente, o pai mergulha no mundo do trabalho e as demais crianças que compõem o sistema familiar, passam a viver mais tempo na rua ou sob o cuidado de membros da família extensiva.

Ao viver cada um por si, as crianças saudáveis integrantes do sistema familiar vão tornando-se independentes dos cuidados maternos e expostas aos riscos psicossociais da ausência de proteção.

A ausência de tempo para o diálogo resulta em um padrão de ação e reação, segundo o qual os indivíduos não procuram entender 0 comportamento um do outro. Há ausência de busca por entendimento acerca dos motivos das ações uns dos outros, dos pensamentos, sentimentos, o que por sua vez não permite o rompimento de padrões negativos e conduz à continuidade do padrão agindo isoladamente.

[...] "eles vão se virando aí, sabe? Eles (filhos) dormem aqui, acordam, de manhã, eles limpam a casa, dividem aí a função deles, e vai né?, a S. (filha) já é grande (10 anos), ela toma banho, se arruma e vai para a escola, o L. (filho) também, o J.(filho) como é pequeno, a minha cunhada que dá banho quando eu não tenho tempo, arruma e põe para ir para a escola, O L.(filho), o meu mais velho, como não está trabalhando, ele busca o J.(filho) na escola, e assim vai indo... eles vão se virando [...] eles (filhos) têm que me ajudar mais né?, por causa da S. (filha doente) antigamente não existia, por que eu não tinha a S. e tinha mais tempo para cuidar da casa, para fazer as coisas para eles, agora com a S. fica mais difícil, eu tenho que me dedicar mais à ela" [...] (Mãe, família 3)

[...] "você não tem mais tempo para nada, se eu não tivesse $o \mathrm{Y}$. (filho saudável) ainda teria, mas como eu tenho o Y... Tem hora que dá vontade de deixar tudo aqui e sair correndo... você olha, ficar com duas crianças pequenas, a D. com esse problema dá vontade, porque que nem o Y., está numa fase que é.. isso aí... 
qualquer coisa fica jogado no chão, e não adianta eu querer arrumar a casa e querer que ele (filho) fique sentado 24 horas no sofá assistindo televisão que ele não vai ficar e tem horas que você perde a cabeça, e tem horas que se eu estou trocando a D., que eu estou fazendo alguma coisa com ela que...e ele (filho) está me puxando e chorando, e gritando e esperneando, aí você fica doida da cabeça... e eu não saio não vou para lugar nenhum, então você fica só aqui dentro, aqui dentro, cuidando deles e daí você fica com a cabeça meio atormentada" [...] (Mãe, família 2)

Esse padrão de relacionamento gera um ciclo de cobranças externas e autocobranças, sobrecarga, dificuldade para visualizar alternativas para a resolução dos problemas e intenso desgaste físico e emocional, em que todos se percebem sentindo-se excessivamente exigidos.

A desintegração do sistema familiar é uma experiência desoladora, que inviabiliza transformações, aumenta a rigidez do padrão estabelecido e impede os indivíduos de seguirem suas vidas (como gostariam de segui-las), alterando profundamente a visão de si mesmos e de suas possibilidades de emergir do sofrimento. A vida é consumida pela mágoa, pela dor, pela solidão, pela ausência de solução frente aos problemas e pela luta frente à não aceitação da condição de vida da criança e da família.

A vitimização do filho e de si mesma e o viver isoladamente representam a invasão devastadora do sofrimento na vida familiar que, diante da inabilidade do sistema familiar em lidar em não se deixar dominar pelo sofrimento, atribuir significados efetivos e proporcionar apoio mútuo, geram o sentimento TENDO A VIDA IMERSA NO SOFRIMENTO.

\section{ESFORÇANDO-SE PARA AGUENTAR}

Dentro desse mundo de privação as opções disponíveis para o enfrentamento efetivo se tornam quase imperceptíveis, diante do intenso sofrimento e do esforço que é direcionado a aguentar.

Nesse esforço em aguentar, a mãe que se vê, muitas vezes, completamente sozinha e procura agir tentando manter a fé, buscando 
conforto na religiosidade e nas orações diárias, acreditando que um milagre possa acontecer, como forma de manter a esperança projetada na melhora da saúde da criança. Com a melhora da criança, a possibilidade de resgatar sua própria vida que, em sua percepção, parou no tempo.

$\mathrm{Na}$ busca por significados que promovam a esperança diante da desolação de viver em um mundo de privação, a mãe tenta consolar-se Imaginando que a vida poderia ser pior, se a criança ainda estivesse no hospital ou não tivesse sobrevivido, tentando manter a auto-estima, valorizando-se por ter aprendido e conseguir manter o cuidado do filho e também por pensar que está fazendo o bem, cuidando para mantê-lo vivo a seu lado. A mãe também tenta manter a autoestima, valorizando poder contar com os profissionais de saúde, não só para o cuidado da criança, mas para ouvi-la e ampará-la nos momentos de extrema aflição, como uma percepção de que alguém no mundo ainda se importa, quando não encontra apoio dentro da própria família.

No esforço para tentar aguentar, a mãe se vê acreditando em si mesma, pensando que é forte e que irá conseguir superar, mesmo sozinha, que irá encontrar uma saída diante da privação e do sofrimento; e questionando-se diante da desolação como forma de tentar encontrar significados para o investimento de esforços na tentativa de melhorar a vida pessoal e familiar.

No esforço materno para aguentar, há também uma luta para encontrar aspectos positivos, e evitar a deteriorização das relações e colapso definitivo do "mundo familiar".

[...] "eu me faço essa pergunta, eu me pergunto 'o que eu posso fazer para me ajudar? A ser um pouquinho melhor?', mas eu não acho respostas... Eu falo puxa vida! Por que só eu? Porque que eu tenho que largar tudo, porque eu tenho que, sabe? Eu tenho que deixar a minha vida, eu tenho que pensar em outro ritmo" [...] (Mãe, família 7)

[...] "eu tenho fé ainda, eu sei que se for da vontade de Deus, num piscar de olho, mais eu sei que... agora eu tenho consciência que é um milagre mesmo, tem que ser um milagre muito grande, tem que ser um milagre para ela (filha) poder, porque se não ela já tinha falado, ela tem cinco anos, e ela nunca falou mãe, só em 
sonho né?, mas eu tenho consciência que eu vou conseguir...tipo assim todo mundo se acostumou com aquilo, nem liga para saber como que está mais... mais eu sei que posso, eu sou forte, eu vou conseguir, e é por isso que eu tenho conseguido, mas assim... igual as pessoas falam, eu não sei, eu conheço muita gente (outras mães) que fala que é tranqüilo, mas não é!, é assim... é um sofrimento contínuo, é coisa de você olhar assim para o futuro e não ver nada, é só sabe? Não consegue você olhar assim e imaginar... uma coisa boa mais... você sabe que está sofrendo, e você finge que não está, sabe assim? [...] (Mãe, família 6)

[...] "eu tento dar a volta por cima, de tudo que aconteceu, por que se eles (filhos saudáveis) me vêm chorando e choravam também, quando eu estou meio triste... eu não sei se você percebeu, mas eu estava conversando aqui a S. (filha) subiu, me viu chorando e já desceu, ela já estava chorando também... e se eles me vêem triste, chorando até o J.(filho) chora ele fica 'mãe, por que você está chorando? Mãe você está chorando por que a S. (irmã) está assim?, ah Deus cura minha irmã para a minha mãe não ficar chorando!', assim, sabe? Eles sofrem junto comigo, então, eu tento relevar, dar a volta por cima, mas é muito difícil" [...] (Mãe, família 3)

Nesse esforço para aguentar a experiência que vive, a mãe pode encontrar uma esperança efetiva, mudar ou ampliar o foco para o qual dirige suas ações e encontrar uma saída que a possibilite movimentar-se para fora do mundo de privação e emergir do sofrimento SENTINDO-SE CAPAZ DE LIDAR COM A SITUAÇÃO, como pode manter o movimento cíclico e fechado VIVENDO O ESGOTAMENTO e ESFORÇANDO-SE PARA AGUENTAR, secundário a CRIANDO UM MUNDO DE PRIVAÇÃO e o contínuo de desolação TENDO A VIDA IMERSA NO SOFRIMENTO, gerado pelo isolamento, pelo desamparo, intensa tristeza e aflição diante do sentimento de incapacidade para lidar com a situação.

Se a mulher/mãe tem o potencial de gerar um ambiente de privação, de intenso sacrifício e de sofrimento, também tem o potencial de modificarse e de transformar a vida familiar, quando direciona seus esforços no sentido a recuperar e manter a coesão interna do sistema familiar, além da integração com seu ambiente.

O sentimento de capacidade de lidar com a situação impulsiona os indivíduos a direcionarem seus esforços de modo a saírem de uma condição 
de desolação e serem mais proativos e acreditarem no potencial que possuem para gerar transformações em suas próprias vidas.

A capacidade para lidar com a situação deriva de um conjunto de habilidades aprendidas nessa experiência circunstancial de vida, especialmente, a habilidade cognitiva para modificar crenças, atribuir significados efetivos, incorporar novas definições para a situação e para o próprio self, habilidades para negociar papéis, expectativas, perspectivas e metas; e também, habilidade para buscar parcerias e estabelecer conexões efetivas em seu próprio ambiente de vida.

O sentimento de capacidade para lidar com a situação permite ao sistema familiar ampliar o foco de PRESERVAR A VIDA DA CRIANCA para PRESERVAR A VIDA FAMILIAR e movimentar-se efetivamente de um MUNDO DE PRIVAÇÃO para um MUNDO PARTILHADO.

\section{PRESERVANDO A VIDA FAMILIAR}

É a forma como o sistema familiar se organiza, tendo com foco PRESERVAR A VIDA FAMILIAR. Preservar a vida familiar é uma forma de organização que reflete a integração das ações direcionadas a preservar a vida da criança na totalidade da vida familiar.

Esse padrão de organização reflete um conjunto de valores construídos e preservados ao longo das experiências de vida em família, que relevam componentes morais e emocionais de forte compromisso uns com os outros e com a história familiar, de pertencimento ao sistema familiar, representado pelo valor de estarem juntos, aprenderem juntos e superarem as dificuldades juntos e por sentimentos de interdependência entre si e em relação ao meio em que vivem. Valores estes que fazem parte da cultura da família, que como unidade se mantém graças ao apoio e ao cuidado mútuo. Junto à cultura familiar de cuidado, adicionam-se as 
habilidades adaptativas aprendidas na experiência de doença da criança e na transição para o cuidado domiciliar.

Desse modo, esse padrão interacional que tem como elemento central PRESERVAR A VIDA FAMILIAR pode ser, tanto reproduzido frente às mudanças nas circunstâncias de vida da família, provocadas pela condição da criança e aprimorado na experiência de transição, quanto produto da experiência de socialização vivida no tempo de preparo para cuidar da criança em casa, como pode ser aprendido circunstancialmente ao longo da experiência de doença, uma evolução derivada do padrão PRESERVANDO A VIDA DA CRIANÇA.

Em tal contexto, o sacrifício empreendido é visto como meio de alcançar uma vida digna e envolve a crença na possibilidade de vencer os desafios cotidianos com coragem e confiança, graças ao esforço persistente e partilhado do sistema familiar.

Esse padrão interacional e o movimento PRESERVANDO A VIDA FAMILIAR refletem a capacidade individual e coletiva para lidar com a situação INTEGRANDO O CUIDADO À VIDA FAMILIAR, a flexibilidade do sistema familiar e a habilidade de agir em conjunto de forma a manter um equilíbrio dinâmico, criando estabilidade nas interações em meio à instabilidade gerada pela circunstância de vida e de criar espaço para conciliar as complexas demandas da vida familiar e de cuidado de saúde da criança e, ao mesmo tempo, de potencializar os recursos CRIANDO UM MUNDO PARTILHADO.

O padrão de organização, que tem como centralidade das ações as refletidas no movimento PRESERVANDO A VIDA FAMILIAR, permite ao sistema familiar constantemente gerar significados efetivos diante das dificuldades e do sofrimento, INCORPORANDO AS MUDANÇAS DEFINITIVAS e INTEGRANDO O CUIDADO À VIDA FAMILIAR e, com isso, definir seus projetos individuais e coletivos REDIMENSIONANDO $O$ PROJETO DE VIDA FAMILIAR e CRIAR UM AMBIENTE DE CURA, 
CUIDANDO UM DO OUTRO e CUIDANDO DO ESPAÇO FAMILIAR, de forma a prosseguir sua trajetória de vida PERSEVERANDO.

\section{INCORPORANDO AS MUDANÇAS DEFINITIVAS}

A forma como os indivíduos veem as mudanças definitivas geradas pela condição de vida da criança, influenciados por um conjunto de crenças sobre as mudanças e sobre a possibilidade de viver com as mudanças, é determinante sobre a forma como a família assimila a condição de vida e organiza-se interacionalmente para manter um funcionamento efetivo.

A perspectiva compartilhada adotada pela família permite a concepção de que as circunstâncias de vida se transformam a partir do evento de doença e que essa transformação é irreversível e, portanto, os indivíduos que compõem o sistema familiar devem modificar-se cognitivamente, para internalizarem as mudanças em suas vidas, em suas identidades, papéis e expressividade.

A concepção de que as mudanças na vida familiar sejam definitivas e irreversíveis mobiliza a tomada de decisão, sobre a forma de como viver o presente, incorporando situações que não podem ser controladas ou vencidas.

Ao acreditar que é preciso continuar vivendo, a família é impulsionada a continuar sua trajetória e, para isso, precisa agir desprendendo-se das perdas passadas. Desprender-se das perdas passadas, significa superar e reparar, transformando-as em aprendizados de vida.

[...] "Tem que tocar a vida para frente. O que passou, passou... a gente tem que né?, tem só exemplo para dar para quem vem vindo atrás... que a gente batalhou, lutou e continua batalhando e lutando sem nunca baixar a cabeça, e nem desistir... entendeu?[...] (Pai, família 4)

[...]" Muitas vitórias eu já consegui do U. (filho) para mim mesmo, muitas vitórias que eu já consegui, de orientar outras mães pelo o que eu já passei, e a mãe vai e fica, me agradece, e isso e aquilo 
e eu fico 'oh meu Deus o que, que eu fiz?' eu já me sinto, praticamente vitoriosa" [...] (Mãe, família 8)

O passado torna-se um instrumental para lidar com os desafios e dificuldades presentes, pois ao acessá-lo os indivíduos procuram ressaltar as conquistas, a superação por meio da mobilização de forças inimagináveis, as vitórias e os aprendizados. O passado torna-se motivo de orgulho e, ao sentirem-se orgulhosos de si mesmos, sentem-se motivados e confiantes na linha de luta orientada para a melhora das condições de vida familiar, dentro das possibilidades e dos limites impostos pela circunstância de se viver em casa com uma criança com necessidades especiais de cuidado de saúde.

O presente é percebido como benéfico, diante das transformações possibilitadas pelas vivências do passado e a unidade familiar sente-se mais fortalecida e com fortes sentimentos de solidariedade, expressos na capacidade e na disponibilidade para prover ajuda, tanto internamente, por meio de ações de cuidado mútuo, quanto para a comunidade em que vivem. A postura do sistema familiar frente à vizinhança, à comunidade e para outras famílias é ativa, tanto para a obtenção, quanto para a promoção de aprendizados e ações que visem o bem-estar.

A aprendizagem é utilizada como instrumental para lidar com os constantes desafios impostos ao sistema familiar e também é direcionada para prover ajuda para outras famílias que vivem circunstâncias de vida semelhante em função da doença da criança.

A transformação dos indivíduos que compõem o sistema familiar, para aceitar e internalizar as mudanças de vida, por meio da busca de compreensão e sentido compartilhado para as dificuldades passadas e para os desafios presentes, permite à unidade familiar tornar-se mais integrada, manter-se coesa ao longo do tempo e adquirir controle sobre sua situação de vida. 
Para tanto, é preciso aceitar e internalizar as condições que se apresentam, aceitar os riscos, os limites, as novas identidades e negociar papéis sociais, que envolvem a escolha e a capacidade de doar-se para assumir novas atribuições dentro do sistema familiar e, ao mesmo tempo, aceitar ter de deixar funções sociais, sem a sensação de renúncia, perda ou abandono.

Para que a família adquira controle da situação e continue vivendo, também é preciso incorporar a ideia de aspectos da vida que independem do esforço ou da vontade pessoal e, portanto, não podem ser previstos ou controlados e ir aceitando os riscos, aceitando que não pode controlar o futuro nem da criança e nem da unidade familiar é uma ação que permite a família aceitar a imprevisibilidade da condição da criança e centrar-se em suas opções disponíveis e em suas escolhas sobre a forma como pode viver o presente.

[...] "a gente que tem filho especial sabe do risco, pode não aceitar, mas sabe do risco de perder, tem que estar ciente, tem que aceitar, o risco é constante, então, é complicado, faz falta, vai fazer, mas você pode brigar com algo que você não pode lutar?, não dá, é complicado, é difícil, mas tem que aceitar" [...] (Mãe, família 5)

As opções disponíveis para a família apresentam-se limitadas, seja pela condição da criança, pela imprevisibilidade do tempo de vida, seja pelas próprias condições socioeconômicas da família. No entanto, é preciso continuar vivendo com tempo e com os recursos que possui, aceitando a limitação como parte da vida, que envolve ainda aceitar os limites e a dependência da criança como algo que não pode ser modificado e reconhecer os limites físicos e emocionais de cada indivíduo que compõe o sistema familiar, reconhecendo as fragilidades individuais e as necessidades de cuidado e também envolve aceitar as limitações financeiras, instrumentais e sociais, as quais modificam a forma como o sistema familiar interage internamente e com seu entorno social. 
Ao incorporar a ideia de que o futuro não pode ser controlado, mas que é possível escolher como o presente pode ser vivido, o sistema familiar vai aprendendo a viver com a incerteza e o risco, centrando-se no presente e ocupando-se com um dia de cada vez.

[...] "eu procuro não pensar no que vai acontecer, porque se você pensar, você não vive né... se vai acontecer isso, vai acontecer aquilo, se você for pensar, você já... eu já não penso muito nisso... se você pensar você já começa a chorar... as vezes ele (esposo) fica pensando 'ah minha filha tão bonitinha', e eu sempre estou conversando com ele (esposo) digo 'está bom, não pensa nisso não', que Deus é quem sabe né?[...] (Mãe, família 1)

[...] MÃE: "a gente não pensa no que vai acontecer, que nem uma médica, na última consulta da neuro, falou "ah.. você já está pensando, por que pode acontecer alguma coisa com ela (filha)? Aí eu disse "não, não estou pensando" e ela (médica), "ah, então pensa", eu falei "não, não vou pensar, vou deixar para pensar quando acontecer" sabe?, eu falei "ficar sofrendo antes para quê?, acontecer pode acontecer, comigo, com ele (esposo), com ela (filha), com qualquer um de nós...pode acontecer qualquer coisa, mas vai ficar pensando, pensando?"... e ela (médica) "ah, mas já tem que pensar, por que se for para desligar o aparelho, você que tem que falar que é para desligar o aparelho", a médica falando, uma neuro lá que nem atendeu direito a L. (filha), por que tem médicos e médicos né?, tem uns que seria melhor que nem fossem médicos... mas assim... para que ficar pensando né?, a gente tem que aproveitar enquanto ela está bem assim, cuidar e dar carinho, enquanto ela (filha) está bem...PAl: até mesmo por que a gente sabe que as chances dela de vida assim... a vida dela é muito limitada... o mundo né?, fechado que a gente vive com eles né?, então não é que... a gente não pensa no amanhã (mãe concordando), a gente pensa no hoje, a gente cuida dela hoje e amanhã seja o que Deus quiser (mãe concordando) (Família 4).

\section{INTEGRANDO O CUIDADO À VIDA FAMILIAR}

Integrar o cuidado à vida familiar reflete os esforços do sistema para conciliar as demandas de cuidado da criança com as necessidades especiais de saúde e as demandas de cuidado da unidade familiar como um todo, que mantêm sua continuidade pelas relações de cuidado que estabelece entre si.

Desse modo, os indivíduos agem em conjunto ajustando as expectativas à circunstância de vida da criança e da família; barrando comparações é a atividade mental do sistema familiar utilizada para 
internalizar o padrão de vida da criança e da família, que é único em função da condição da criança e das particularidades de cada família. Barrando comparações também é uma estratégia que permite aos indivíduos a respeitar as individualidades dentro do sistema familiar no que se diz respeito às diferenças nas formas de prover o cuidado ou de responder às circunstâncias de vida.

Entendendo e aceitando as limitações da criança também é uma forma de os pais irem ajustando as expectativas, internalizando as condições e os limites para o exercício da paternidade, que corroboram para a construção das identidades, tanto paterna quanto materna, e para a consolidação dos papéis a serem desempenhados no contínuo da experiência de produção de cuidados de saúde à criança integrada ao contexto interacional do sistema familiar, de forma a possibilitar a participação de todos os indivíduos que partilham da vida familiar e a minimizar a carga e as restrições inerentes à circunstância de vida.

Assim, ao entenderem e aceitarem as limitações da criança, os pais conseguem alterar o foco de pensamento dos riscos e perdas para os benefícios e as possibilidades. Desse modo, a condição de vida da criança passa a ser vista como uma "nova" normalidade e a tecnologia de suporte de vida é vista como um recurso essencial para a preservação da vida da criança e não como uma fonte de sofrimento.

[...] para mim é muito fácil de eu entender as necessidades da $\mathrm{M}$. (filha), porque eu, hoje, entendo o que ela tem. Então para mim não dói uma gastro, não dói uma traqueo, não é um choque, para mim é fácil porque eu sei da necessidade da $M$. eu entendo tudo o que a $M$. tem, para outra mãe talvez não seja fácil, não é fácil talvez, porque ela não compreenda a necessidade do filho ou porque ela pensa... 'ah meu filho não vai andar, não vai falar...'a sociedade que infelizmente te julga, infelizmente eles olham diferente, mas para mim não dói uma traqueo, gastro, não, pelo contrário eu fico feliz que ainda tem um recurso, pior ser for uma doença que eles chegam para mim e falam assim: ' $F$. não tem $o$ que fazer', ai eu vou ficar ruim..., mas enquanto tiver recurso e puder, ah eu estou feliz, está ótimo... é ruim quando a pessoa não aceita, isso dói [...] (Mãe, família 5)

[...] "A L. (filha) tem o probleminha dela, dos aparelhos, tipo o respirador, mas a gente leva como se fosse uma criança normal, a gente cuida, a gente dá banho, então, assim, no conceito assim... familiar, a gente leva tudo normal, para a gente o normal é 
ter ela (filha) assim... o normal é a gente cuidando dela (filha) do jeito que ela (filha) é, o normal dela é isso, e esse é o nosso normal [...] (Pai, Família 4)

Ao internalizarem a realidade de vida da criança, da família e irem ajustando as expectativas, os pais vão adequando o cuidado às necessidades da criança, pois conseguem alterar o foco de seu próprio self, ou seja, daquilo que esperavam para si mesmos como pais e, ao mesmo tempo, irem moldando a possibilidade de serem pais. Desse modo, os pais internalizam a ideia de que o cuidado, como meio de preservar a vida da criança, manter o bem-estar e manter a criança em casa no ambiente familiar pelo tempo em que a criança viver, é o melhor que podem fazer como pais e se veem cuidando da melhor maneira possível.

Quando os pais se percebem cuidando da melhor maneira possível, conseguem identificar os benefícios do cuidado produzido pelo sistema familiar em seu próprio ambiente doméstico, acreditando que o mais importante é a criança estar em casa. Estar com o filho em casa, independente de suas condições de vida, sendo cuidado pelos pais e integrado à vida e ao ambiente familiar é o principal benefício, o que confere naturalidade e normalidade à vida familiar.

Conforme os pais vão ajustando suas expectativas em relação à circunstância de vida da criança e da família, ao cuidado e ao tempo, vão direcionando seus esforços e sacrifícios de forma a transformar a experiência de viver com a criança em casa em um benefício para todos os membros do sistema familiar.

[...] "o que me dá mais força assim é ver que ela está bem...ver que a gente lutou até agora e ela está bem né? o que me dá mais força ainda né, todo o dia eu peço a Deus me dar saúde, para eu estar cuidando dela (filha), o que eu posso fazer para ela estar bem eu faço... ou seja, se eu estou cansada, seu eu estou triste eu procuro não transmitir para ela (filha), porque ela não transmite isso aí para mim, ela transmite que sempre estar bem, em paz, estar feliz, assim... então é isso que me motiva a cada dia, a cada dia estar lutando, por ela estar bem, e eu quero que ela esteja melhor ainda, as vezes eu fico triste com ela aqui... de cabeça baixa... só basta ela dizer mamãe, mamãe, mamãe achou! Então aquilo passa, eu penso ah, ela está tão feliz, porque que eu vou reclamar, eu peço todo dia para Deus, muito, sabe? Que me dê 
saúde para cuidar dela, que me dê forças para poder estar cuidando dela, porque ela está bem hoje, então isso me dá força, eu ver ela bem, sabe? E ficar melhor ainda" [...] (Mãe, família 1)

As interpretações que os pais fazem acerca dos benefícios do cuidado produzido de forma integrada ao ambiente e à vida familiar permitem que sigam fortalecendo-se nos resultados do cuidado. Os pais identificam os resultados do cuidado: ao verem o bem-estar da criança e a estabilidade clínica proporcionada pelo cuidado provido no ambiente domiciliar; ao verem, também, que a criança superou as expectativas de vida limitadas pelo diagnóstico; ao acreditarem que a criança transmite estar em paz e feliz por estar junto da família.

Assim, os pais sentem-se confiantes e recompensados por seus esforços, o que traz em si motivação para continuarem lutando para preservar a vida da criança e preservar a vida familiar, conciliando as demandas do sistema familiar como um todo, de forma a seguirem sua trajetória, cuidando e vivendo o dia a dia.

Os esforços para conciliar as demandas do sistema familiar consistem um conjunto de habilidades relacionais, direcionadas à resolução dos problemas, ao manejo das mudanças e dos desafios da vida cotidiana de forma partilhada, de modo a integrar as demandas impostas pela circunstância, gerada pela necessidade de cuidado especial da criança de forma contínua e complexa no domicilio, bem como, as demandas desenvolvimentais do sistema familiar.

[...] "Eu consigo conciliar tudo, a $\mathrm{M}$ (filha doente). nunca foi um problema. E como eu te falei eu não deixo nem de mim, nem dos outros por causa da M.A M. é assim, é o que eu falo, a M., eu acho que é a pessoa mais amada aqui dentro. $\mathrm{O}$ bom é que eles (filhos) entendem isso e não me cobram com a M.Eles sempre souberam respeitar que a hora dá $M$. é a hora da $M$. não existe cobrança. Agora é assim não é justo deixar de viver e deixar dos outros viverem por causa da $M$. porque a $M$. querendo ou não, o tempo que ela tiver aqui vai ser assim. Eu não posso me privar e nem privar a vida deles por conta da M. Então eles têm que são, eles (filhos) tem que se divertir, eles tem médico, eles têm dentista, eles têm escola, eu não posso deixar interferir na vida deles que tem que seguir por causa da M. Do mesmo jeito que eu não vou deixar de viver por causa da M. É assim, eu vou cuidar ao 
máximo como eu sempre cuidei da M. Eu, eles (filhos) e minha família que é minha mãe e meu pai [...] (Mãe, família 5).

Para tanto, o sistema familiar empreende estratégias de forma a organizar-se de acordo com as opções que dispõe em seu próprio espaço relacional para enfrentar os desafios cotidianos, os quais envolve linhas de ação desenvolvidas em conjunto e que são refletidas no processo CRIANDO UM MUNDO PARTILHADO.

\section{CRIANDO UM MUNDO PARTILHADO}

As habilidades sistêmicas para o estabelecimento de parcerias, de busca de cooperação para a resolução dos problemas e de aprendizagem partilhada contínua, como uma qualidade de sociabilidade individual e coletiva, são refletidas no processo CRIANDO UM MUNDO PARTILHADO.

Desse modo, CRIANDO UM MUNDO PARTILHADO envolve as linhas de ação negociando o cuidado, estabelecendo limites, potencializando recursos, dividindo os desafios, administrando o tempo familiar e abrindo canais de comunicação

Ao ir negociando o cuidado, as demandas são continuamente ajustadas aos recursos disponíveis no ambiente familiar. $O$ que envolve potencializar os recursos, capacitando pessoas para cuidar, de forma que todos que partilham do convívio familiar assumam atribuições e engajem ao movimento de manter o equilíbrio funcional do sistema familiar, dividindo os desafios financeiros e sociais com a rede de apoio social.

[...] "a gente comprou uma cadeira para ela, fez uma cota, todos os parentes ajudaram, daqui, da Bahia, cada um deu um pouquinho para a gente conseguir comprar a cadeira, a gente tem ajuda de uma pessoa, que ela vê que a gente precisa e ela divide com a gente... mas... é uma mãe que tem um coração muito bom...a gente recebe bastante visita, final de semana, dos irmãos, tios que moram aqui... vira e mexe a gente recebe uma visitinha. Tem os vizinhos também que gostam de ajudar" [...] (Mãe, família 11) 
[...] quando tem alguma coisa, a gente quer sair junto (casal), a gente "F. você pode ficar com a L.?" , ela sabe aspirar, sabe tudo, esses dias minha irmã veio, eu disse "C., não vai aprender não? a aspirar a L.?" tem que aprender, se precisar... e ela "ah, hoje não", vai aprender que dia?... só a F. que sabe, além de nós dois, só ela que sabe cuidar [...] (Mãe, família 4)

Além de negociar o cuidado de forma a que todos possam participar, é preciso estabelecer limites para a provisão do cuidado. Agindo-se dessa forma, a adequação do cuidado às necessidades da criança torna-se fundamental para o controle da carga de responsabilidades, papéis e obrigações que os pais assumem, bem como da sobrecarga física e emocional. Assim, os pais proveem o melhor cuidado para a criança, tendo consciência do que realmente irá beneficiá-la e evitam esforços e desgastes desnecessários, no sentido a preservarem seu próprio bem-estar físico, emocional e social, além do bem-estar da unidade familiar.

A negociação, o cuidado e estabelecimento de limites são estratégias que permitem que o tempo familiar, espaço relacional, sejam administrados de modo a não serem consumidos pelas intensas atividades instrumentais e rotineiras, geradas pela demanda de cuidado da criança.

[...] "eu respeito a limitação da M (filha). Eu tento dar o suporte do que ela precisa, não do que eu quero, é diferente, entendo... toda a limitação eu entendo, toda doença eu entendo, eu entendo tudo dela. Então eu sei o que dá para M. e o que vai beneficiar a M. e não o meu ego, vamos dizer assim. Então, eu faço pra ela o que ela precisa, nada além do que ela precisa. Ela está precisando do que hoje? De cuidado." (Mãe, família 5)

Administrar o tempo familiar implica em um conjunto de ações direcionadas à organização da dinâmica interna do sistema familiar, direcionada a programar e estruturar as atividades diárias, de forma que permita, tanto a individualização do tempo da criança com necessidades especiais de cuidado, quanto a individualização do tempo pessoal e dos demais relacionamentos familiares e sociais. 
Como forma de compensar a imobilidade gerada pela condição da criança, o sistema familiar vai abrindo canais de comunicação como forma de manter-se continuamente atualizado, o que potencializa as habilidades de criar alternativas para a resolução dos problemas cotidianos.

[...] "A gente conversa muito, que na escolinha que ela (filha) freqüenta, as mães todas passam por essa mesma dificuldade, então tem mães que já estão nessa luta há muito anos atrás, muito tempo, assim que os filhos já são bem maiores né?, então já enfrentaram várias experiências, várias dificuldades, e a gente começa a conversar 'ah, fulana como você conseguiu isso, com quem você falou...' e 'ah, a gente foi atrás, de um lugar assim e assim que fornece, a gente falou com fulano...' e a gente assim 'ah, então passa o endereço para a gente', e é assim, sempre, indo atrás de informações... quando eu vejo uma mãe que está assim recente, com criança assim, eu passo todas as informações, mesmo não sendo... mesmo não tendo amizade, eu pego amizade com as mães que eu não conheço, e falo 'olha eu consegui tal coisa, assim e assim para a minha filha, você conseguiu também?', 'não, não consegui, onde você conseguiu'... aí eu falo 'consegui em tal lugar, assim e assim', já passo logo todas as informações 'em tal lugar, fornece isso, fornece aquilo, nos conseguimos isso e aquilo, o endereço é tal, o telefone é tal'... tudo sabe, e as mães vão atrás também, teve uma mãe que conseguiu uma cadeira no mesmo lugar que a gente conseguiu a da L. (filha), no advogado também, até fui eu que fui lá com ela buscar a cadeira da filha dela. E isso ajuda, porque a gente passa experiência uma para outra, porque que conviveu com isso sabe né? não custa a gente passar... e eu sempre estou em contato com elas (mães), de todas eu tenho o telefone. As vezes no hospital, quando ela (filha) fica internada, a gente conversa com algumas mães que tem criança assim, também... pesquisar também as informações delas para a gente, a convivência, as experiências que elas passam, tem umas que já passaram por várias experiências na nossa frente, que foram aprendendo. $\mathrm{E}$ a gente vai aprendendo a correr atrás dos nossos direitos.... por que a convivência mesmo com ela (filha) a gente vai aprendendo no dia a dia dia, mas os nossos direitos que a gente não sabia [...] (Mãe, família 9)

O conjunto de ações articuladas no processo CRIANDO UM MUNDO PARTILHADO permite ao sistema familiar ampliar seu espaço relacional, configurado pelas interações internas e externas ao ambiente doméstico. Criar um mundo partilhado é uma estratégia que permite abertura e disposição para a interconexão e o apoio, o que torna possível a continuidade do sistema familiar, representada pelas ações REDIMENSIONANDO O PROJETO DE VIDA FAMILIAR e PERSEVERANDO. 


\section{REDIMENSIONANDO O PROJETO DE VIDA}

Ao criar um mundo partilhado, o sistema familiar readquire os meios para viabilizar o projeto de vida familiar. O redimensionamento do projeto de vida refere-se ao ajustamento de ações e interações do sistema familiar, articulados às mudanças em suas circunstâncias de vida, e reflete a habilidade sistêmica de negociar as expectativas de vida familiar.

O redimensionamento do projeto de vida permite ao sistema familiar manter o sentido de continuidade, diante da concepção que é preciso continuar vivendo. O redimensionamento do projeto de vida permite aos indivíduos manterem o senso de autonomia e autodirecionamento, além de se engajarem em um movimento de busca de realização pessoal e de satisfação no contexto da vida familiar.

Redimensionando o projeto de vida familiar, envolve agir ajustando os planos de acordo com as condições que a vida concreta oferece, o que envolve um conjunto de possibilidades restritas às circunstâncias geradas pela condição da criança.

[...] "Os planos de ir embora 'arriou', os planos de ir embora, agora vai ser um pouco difícil, porque ele (esposo) falou do tratamento, mas agora a medicina não tem um tratamento para ela (filha), que cure, na medicina não tem, talvez, igual ele (esposo) falou seja possível um dia ter... então a gente iria... PAl continua: já que a gente está aqui, tenho planos de conseguir assim as coisas... MÂE: então o plano da gente é um só, conseguir uma casa aqui, os planos, tanto para gente como para nossa filha, um conforto maior para ela, e para a gente" [...] (Família 11)

Desse modo, ajustar os planos no contexto de um mundo partilhado, envolve estabelecer metas conjuntas que possam ser realizadas em um curto prazo, dentro das limitações socioeconômicas, espaciais e temporais da família e que tragam benefícios à vida familiar. Assim, as metas estabelecidas são direcionadas à melhora do espaço familiar, das condições educação, de trabalho e de renda da família.

O redimensionamento do projeto de vida familiar tem como foco a totalidade, mas também a individualidade dentro do sistema familiar; 
encorajando a busca de satisfação é uma ação que visa à promoção do movimento de busca de realização dos planos pessoais.

Ao redimensionar o projeto de vida, os indivíduos se percebem resgatando sonhos que foram de certo modo interrompidos diante das demandas de adaptação provocadas pelas transformações nas circunstâncias de vida. Além de continuar vivendo, é preciso manter a capacidade de sonhar, como algo que gera motivação e ilumina o futuro. Assim, cada indivíduo mantém seus sonhos vivos, como o sonho de ter outros filhos ou de adquirir um automóvel, como meio de poder realizar o sonho de sair de casa com a criança com necessidades especiais.

[...] eu já falei para ele (marido), eu estou com um sonho na minha cabeça, eu pretendo ter esse sonho e conseguir, pode ser obsessão, pode ser, mas pode falar você esta obcecada por isso e aquilo, eu estou é vontade de aprender a dirigir, e a vontade de conseguir a minha carta um dia, ate porque eu estudo mais por causa disso, porque eu pretendo conseguir a carta algum dia, e eu vou tentar conseguir, porque se eu conseguir tirar a carta, ferro velho, fusca isso e aquilo, você tenta conseguir da maneira possível, não pensa em carro novo, não pensa em carro bom, mais o que importa e que você pode levar ele (filho) no mercado, pode levar em uma terra diferente da rua da gente para pisar, então ultimamente, para ser sincera eu estou obcecada nesse sonho, e eu vou conseguir! [...] (Mãe, família 8)

\section{PERSEVERANDO}

Ao redimensionar o projeto de vida familiar, o sistema mantém sentido e o amparo para as relações familiares, de forma a prosseguir sua trajetória PERSEVERANDO.

No movimento perseverando, os indivíduos seguem suas vidas acreditando que tudo é possível. A crença de que tudo é possível, permite que eles encontrem solução para seus problemas e que não haja espaço para a dúvida ou preocupação.

[...] "E eu acredito que na nossa vida é assim, é cheia de altos e baixos, a nossa vida é uma estrada, uma estrada, quando você vai viajar para um lugar, para um país, um estado, para onde quer que seja, aquela rodovia não é um tapete até chegar lá, tem curva, tem 
buraco, tem subida, tem lombada, não é? tem farol, você não vai daqui direto... mesmo que você planeje ir pela Castelo Branco 'vou pegar a Castelo que é um tapete', não, tem pedágio, tem que parar... e na nossa vida é assim, você está indo... e daqui a pouco, você opa!, apareceu um problema, tem que parar também, então você tem que aprender, aprender a viajar, logo lá na frente... quantos que já passaram por essa vida né Aline?, quantos que já enfrentaram tantos problemas, se for ver a vida deles atrás, quantos problemas que eles já enfrentaram, passaram... a vida da gente é essa, nós temos que passar por isso, então vamos passar, mas vamos passar feliz, logo, logo passa tudo, e lá na frente é outra vida, e... né L. (falando com a filha) tem que confiar em Deus, não tem nada impossível [...]" (Mãe, família 9)

Ao acreditar que tudo é possível, os indivíduos e grupos familiares aprendem a viver sem medo e seguem suas vidas confiando, mantendo o otimismo diante dos desafios cotidianos, mantendo a fé e fortalecendo a esperança. Desse modo, a fé é componente presente nas ações e interações familiares, pois estimula os indivíduos a pensarem para além da situação concreta e, desse modo, visualizarem suas vidas de forma mais ampla, assumindo diferentes verdades acerca do futuro e a sentirem-se constantemente amparados nos momentos de fragilidade.

O fortalecimento da esperança é o que promove o sistema familiar em sua luta empreendida diariamente diante de uma perspectiva orientada à confiança de que irão conseguir alcançar suas metas e de que a vida familiar seguirá preservada.

\section{CRIANDO UM AMBIENTE DE CURA.}

A preservação da vida familiar, por meio dos esforços integrados do sistema familiar, tem como consequência CRIANDO UM AMBIENTE DE CURA.

Criando um ambiente de cura representa o processo de envolvimento cooperativo do sistema familiar, de forma a criar um ambiente caracterizado pelo tempo e espaço relacional da família, no sentindo de promover a cura para o sofrimento. Independente de existir cura física para a doença da 
criança, a unidade familiar cura-se emocional, social e espiritualmente graças ao cuidado: CUIDANDO UM DO OUTRO E CUIDANDO DO ESPAÇO FAMILIAR.

\section{CUIDANDO UM DO OUTRO}

\section{O padrão de comportamento CUIDANDO UM DO OUTRO é} mobilizado pela crença de que todos sofrem e todos precisam de cuidado para manterem suas forças ao longo da trajetória, o que evidencia a percepção reconhecendo a vulnerabilidade do sistema familiar.

Assim, ao agirem reconhecendo a vulnerabilidade do sistema, coenvolvem o reconhecimento da fragilidade e das forças como uma interação dinâmica, que se altera em função da realidade que está sendo vivida e que é preciso estar apto a prover o apoio para todos, de acordo com as particularidades das manifestações do sofrimento e das dificuldades vividas por cada um dos indivíduos dentro do sistema familiar.

[...] MÃE: "a gente conversa né? (olhando para o marido) muito (risos), tem dia que a gente fica aí só conversando... do sofrimento assim das coisas..." PAl: "dia de sábado..." MÃE: "porque a gente já passou por muita coisa né? muita, muita coisa, tem muita gente que se afasta né?..." PAl: "a gente consegue muito amigo né, Aline, com o problema da L., mas a gente perde aqueles amigos antigos, que a gente tinha, a gente perde...mas em compensação a gente conseguiu muita gente, muito amigo mesmo...então tem dias que a gente fica só conversando... por tudo que a gente já passou... MÃE: e eu estou sempre conversando com ele (marido/pai), falando, porque ele já mais nervoso do que eu, então eu tento ser mais forte, para dar força para ele, então a gente sempre está conversando" [...] (Família 1)

[...] "se éramos unidos antes, hoje somos muito mais unidos ainda e... não por causa que ela (filha) é doente nada... por que até mesmo por que a gente (casal) se gosta, sempre se gostou e... né? (olhando para a esposa)... a gente tem um relacionamento de marido e mulher normal, e... que nem, tem muitos casais que ficam juntos por causa da criança, e... a gente não a gente já gosta um do outro, a gente gosta da L. (filha), e... é isso aí... a estabilidade familiar, a gente pode falar que é nota mil, não é verdade? (olhando para a esposa, que concorda e sorri). Eu cuido delas (filha e esposa) e ela (esposa) cuida de mim, e o resto a gente vai ganhando com o tempo [...] (Pai, família 4)

[...] "a gente se tornou mais unidos sabia? A união da família ficou maior, a gente consegue passar pelas dificuldades, bastante 
coisa, unidos. A nossa união é bem estável, lógico que causa uma tensão na sua vida, o cansaço e questão financeira, mas a união ficou maior (a mãe concorda)... [...] (Pai, família 10)

Diante dessa percepção de que todos precisam de cuidado específico, há uma especialização contínua do sistema familiar permitida pela estratégia, abrindo espaço para a expressividade de todos para a expressão de sentimentos e comunicação aberta. Abrir espaço para a expressividade permite a contínua compreensão da fragilidade e do sofrimento individual e a identificação das contínuas necessidades de cuidado.

O fortalecimento das interações de cuidar um do outro permite à família, como unidade, reconhecer e seguir promovendo as individualidades, por meio do respeito e do estímulo constantes ao crescimento individual, o que, por sua vez, promove e fortalece a vida familiar.

\section{CUIDANDO DO ESPAÇO FAMILIAR}

CUIDANDO DO ESPAÇO FAMILIAR representa as ações que visam preservar a convivência, como aspecto central, que simboliza a dinâmica, a complexidade e a subjetividade da vida familiar, construída em seu mundo interno partilhado.

O ambiente criado pela família dimensiona o espaço de suas relações internas e externas. Ao CRIAR UM MUNDO PARTILHADO, o sistema familiar amplia seu espaço relacional e se abre para as possibilidades de convivência e sociabilidade. Ao CRIAR UM AMBIENTE DE CURA, o espaço familiar delimitado pela casa se torna um santuário que preserva o que há de mais sagrado e íntimo na vida familiar, representado pelos valores, memória e história da família e que, portanto, deve ser cuidado.

O espaço e tempo familiar se fundem para a criação de um ambiente de cura e conferem dinamismo para as interações familiares internas e com seu entorno social. O tempo é dimensionado em função dos processos 
envolvidos na trajetória familiar, articulados às transformações nas circunstâncias de vida. O tempo também se torna um recurso estruturante para o cuidado do espaço físico e das relações familiares.

O cuidado do espaço físico envolve um conjunto de ações desempenhadas pelo sistema familiar que permitem o direcionamento, mantendo a casa em ordem, que significa zelar pelo espaço físico de modo a prover conforto e proteção para todos os membros da família, mas também significa manter ordem na vida familiar.

Mantendo a casa em ordem e, portanto, a vida familiar em ordem, envolve ações contínuas de negociação de papéis, tarefas e trabalhos específicos a serem assumidos e desempenhados por cada indivíduo que compõe o sistema familiar, de forma a proporcionar a participação relativa de todos tendo como foco a totalidade. É preciso partilhar das tarefas e dos desafios cotidianos, fazer tudo juntos, como forma de garantir que todos sejam beneficiados.

[...] "A principal coisa é nunca fazer a mesma coisa, sempre ir variando, sempre mudando, esse é o principal ponto, por que se você cair na rotina, já era! ... é o fim da linha... E você de certa forma, você variando... tipo...o seu cérebro variando, você falar hoje eu vou fazer isso, amanhã eu vou fazer aquilo, então você nunca esta repetitivo, nunca esta centrado numa coisa só... vocês está centrado em vários objetivos para uma coisa só, então...né?... você acaba lidando de um jeito mais fácil... que nem... tipo... se eu deixar tudo só para ela (esposa), ela vai se sentir pressionada, né?, e de certa forma, isso não vai acabar, num futuro, dando muito certo, justamente por causa disso, pressiona muito ela (esposa), tipo... só ela (esposa) cuidando da L., só ela fazendo as coisas para a L., então... aí acaba dando desentendimento, um quer falar que faz isso, o outro faz aquilo... né?... por que aqui a gente faz tudo junto de $\mathrm{A}$ a $\mathrm{Z}$, né? (olhando para a esposa, que concorda)... é comida, é lavar roupa, cuidar da L., é tudo! Entendeu? o que ela (esposa) faz eu faço, e o que eu faço ela (esposa) faz... não acaba...não acaba... como que se diz assim... não acaba sendo monótono, não acaba sendo repetitivo, e a gente consegue, mesmo com tantos desafios, ir driblando isso e tocando para frente... isso eu acho que é o ponto principal, por que ela (esposa) me apóia e eu apoio ela (esposa)... e... a gente esta sempre procurando fazer o melhor para poder manter tudo no seu devido lugar" [...] (Pai, família 4) 
Os papéis sociais ordenam a cena doméstica. Eles são assumidos e desempenhados por cada indivíduo e, constantemente, negociados dentro do sistema familiar, delimitam espaços de ação e interação, demarcam a expressividade do sistema e sua sociabilidade, tendo impacto sobre a afetividade, senso de autoridade e de poder, que envolvem o senso de controle sobre a própria vida, relacionados à sabedoria construída no espaço que lhes pertence e pela interpretação de ações efetivas.

Cuidar do espaço relacional familiar requer o constante investimento de energia e esforços do sistema de forma a transformar a experiência de viver dentro de casa, diminuindo a sensação de limitação da liberdade e gerando uma atmosfera acolhedora para todos que partilham do espaço familiar, mantendo relações harmoniosas por meio de ações que preservam a cooperação e evitando o conflito como modo de vida.

Diante de tantos desafios o sistema familiar sabe que é preciso evitar conflitos adicionais e manter a cooperação, mediante constante exercício de entendimento mútuo e alinhamento de ações, de forma a refletir perspectivas partilhadas sobre a situação vivenciada e os problemas cotidianos.

A harmonia, como reflexo do funcionamento integrado do sistema familiar, é possibilitada pelo desempenho de papéis complementares, como um mecanismo de compensação e distribuição constante da carga física, emocional e social e das dificuldades extras geradas pela necessidade de cuidado especial da criança. É, sobretudo, uma forma de não permitir vazios ou ausência de confiança nas relações familiares.

A confiança nas relações familiares permite que cada indivíduo mantenha seus esquemas de referência simbólicos para a atuação e construção de suas identidades. Assim, o papel de mulher é complementado pelo papel do homem, o papel de esposa é complementado pelo papel de marido, os papéis paternos são preenchidos na relação com os filhos saudáveis e doentes, bem como, as crianças adquirem seu lugar dentro do 
sistema familiar, demandando proteção, atenção, carinho e socialização por parte dos adultos.

O reconhecimento das individualidades proporciona a complementaridade das ações de apoio e, desse modo, o frágil deve ser amparado pelo forte, o desesperado pelo tranquilo e assim, continua e sucessivamente, o sistema familiar protege a si mesmo e ajuda a manutenção de um foco de otimismo e perseverança no constante desafio de seguir PRESERVANDO A VIDA FAMILIAR.

A rede familiar e a comunidade adquirem novas funções estruturantes para as relações familiares. O sistema familiar amplia sua sociabilidade e apoio, abrindo espaço para a distraccão e alegria, celebrando os aniversários, como um meio de reunir a família e, ao mesmo tempo, registrar a existência da criança. Reunir a família é uma ação de extremo valor que gera felicidade simplesmente por estarem juntos com sua rede familiar e com as gerações anteriores e mais: por permitir aos pais serem, nesse tempo, também filhos.

Cuidar do espaço familiar, abrindo espaço para a família, os vizinhos e amigos, faz que os indivíduos se percebam extraindo o máximo de felicidade da vida. As estratégias direcionadas a cuidar do espaço familiar, desse modo, permitem que o sistema siga sua trajetória, mantendo a conexão com sua rede de apoio social, mantendo-se amparados, preservando o convívio social e partilhando os desafios, a carga e o custo do cuidado com a rede familiar e social.

[...] "a gente conversa, as vezes ele (marido/pai) não quer ir para algum lugar, quando tem alguma coisa ... eu digo não, vai! E ele (marido/pai) 'ah não eu não vou', porque acostumado sempre a sair junto né?... aí eu falo não, vai! As vezes quando tem algum aniversário, assim, alguma coisa aqui por perto, ele (marido/pai) fala 'não, eu vou um pouco, aí eu venho para casa, aí você vai...(risos)'.Tem que sair um pouco, porque a gente precisa conversar, sair um pouco, conversar mais com as pessoas, distrair também a cabeça tem que sair um pouco também...tem que a prender a conviver não é? Porque antes era... eu tinha medo de sair! Se eu saia eu tinha medo... sabe...pensava se eu saísse se casa alguma coisa ia acontecer... depois eu fui aprendendo a conviver, falei ah, se eu tiver em casa ou não, se tiver que acontecer vai ter que acontecer, então eu vou ter que sair aos poucos...agora eu já saio...deixo com ele (esposo)! Saio... por que 
ele (esposo) cuida muito bem... saio despreocupada..." PAl: "é... quando tem churrasco na casa do nosso amigo, e eles 'vocês vêem' opa, vamos sim... põe a L. (filha) na cadeira dela ali e... vamos L., vem dois, três pega, sobe escada, desce escada, e eu digo oh não pode fumar aqui! Todo mundo respeita, ninguém fuma... ou vai para a casa da irmã dela (esposa), a gente faz churrasco...'MÃE: 'no apartamento da minha sobrinha, a gente também levou ela, quero ver agora quando ela tiver a cadeira dela nova... foi num casamento...da minha sobrinha... nossa! Precisa ver como ela (filha) gosta! Bastante! Para fazer ela vir embora de uma festa, ela vem chorando, o dia que nos fomos no casamento da minha sobrinha, eu dizia L. (filha) 'acabou', ela foi chorando, eu dizia 'L. todo mundo está indo embora', e ela chorando, querendo ficar...ela gosta...(risos)" [...] (Família 1)

[...] PAl: "a gente é mais caseiro também assim (mãe sorri, dizendo ele é mais caseiro)... eu sou mais caseiro!, Por ela (esposa) a gente sairia mais, mas é que não dá para deixar a minha irmã cuidando da L.(filha) sozinha por causa do filho dela que se soltar ele já corre direto para a escada... entendeu? então, não tem como ela (irmã) cuidar dos dois ao mesmo tempo, então a gente não sai, mas a gente... que nem a gente já falou né, os meus parentes vem para cá, a mãe dela (esposa) vem, as irmã dela (esposa), a C.(tia) vem para cá, dorme, fica aqui... (a mãe concorda)" MÃE: "a minha tia vem..."PAl: "o que a gente não sai eles trazem para a gente, proporcionam para nós (mãe concorda), então... eles vem, conversam, sempre os aniversários fazem aqui, faz almoço de domingo..." MÃE: "sempre a gente faz bolo, tem de janeiro até julho aniversário... todo mês... domingo mesmo foi do K, aqui em casa..."PAl: "mês que vem é o dela (esposa)...então, assim... num resumo... a gente não se afastou do mundo, o mundo vem até a gente. Entendeu?... por que a gente não se afastou, nós não perdemos... a gente pode ter perdido um pouco a liberdade de sair de casa, para passear assim né?, mas... assim... de sair os dois juntos... a gente sai assim... vai ao mercado juntos (mãe fala é, vamos no mercado, a F. fica), fazemos compras juntos, quando precisa comprar alguma coisa para ela (filha) a gente vai junto, que minha irmã... quando é assim coisa de uma hora, uma hora e meia, dá para ela ficar... de vez em quando a gente vai ao shopping dar uma olhada nas vitrines [...] (Família 4).

Assim o sistema familiar constantemente investe esforços para preservar seu mundo partilhado e, consequentemente, o sentimento de capacidade para lidar com a situação é promovido e atualizado nas ações e interações familiares. A capacidade sistêmica para lidar com a situação é fortalecida pelo contínuo retorno, de ações e interações interpretadas como efetivas.

Entretanto, o senso de capacidade ou de incapacidade para lidar com a situação, como componentes interacionais dinâmicos, podem sofrer alteração em função de novas mudanças nas circunstâncias de vida 
individual, da criança e da família. A instabilidade e incerteza são constantes na vida familiar, especialmente no que se tange à condição de fragilidade da criança e a disponibilidade de apoio social.

\subsection{O MODELO TEÓRICO}

A compreensão teórica, resultante da análise interpretativa das categorias conceituais e suas conexões, permitiu a construção do modelo teórico DEFININDO O PROJETO DE VIDA FAMILIAR (Diagrama 1), representativo da experiência interacional simbólica da família, na transição para o cuidado domiciliar da criança com necessidades especiais de saúde.

As categorias identificadas, bem como a análise conceitual das relações e conexões teóricas realizadas, evidenciam que a experiência da família na transição para o cuidado domiciliar da criança com necessidades especiais de saúde é um processo complexo e subjetivo que pressupõe a construção de múltiplas realidades de vida familiar e suas conexões com o tempo, com o espaço, com a cultura e com a situação familiar vivenciada.

O processo DEFININDO O PROJETO DE VIDA FAMILIAR releva os movimentos dos indivíduos que compõem a família, a partir da interpretação de sua realidade de vida e da interpretação de suas ações e interações, que evidenciam padrões de organização familiar na situação vivenciada e suas inter-relações com perspectivas derivadas de experiências sociais e culturais construídas ao longo de sua história.

O projeto de vida é o que atribui sentido e aporta à vida familiar, articula-se aos valores incorporados, como legados, e que são, reafirmados ou reconstruídos, diante de sucessão de acontecimentos que acompanham a existência de cada família e orientam suas obrigações futuras. $O$ projeto 
de vida familiar é dinâmico em sua essência, visto que é um processo que se manifesta nas ações e interações familiares e que, por sua vez, envolve o alinhamento de ações individuais, estruturadas pelo tempo e pelo espaço da família. O projeto de vida familiar promove ligações com a história e integra os planos para o futuro, que partem dos meios que a vida concreta proporciona e envolve um conjunto de componentes emocionais e diferentes níveis de sonho e de fantasia.

O projeto de vida integra os elementos que compõem o universo simbólico familiar, que conferem singularidade, complexidade e dinamizam a vida familiar e está sujeito a constantes transformações, conforme as circunstâncias de vida se alteram.

A incidência, na vida familiar, de uma doença grave, incurável, limitadora, tanto do tempo, quanto das condições de vida da criança é interpretada pela família como uma situação psicossocial potencialmente devastadora definida como TENDO O PROJETO DE VIDA FAMILIAR AMEAÇADO, diante da percepção dos riscos e da probabilidade de modificar definitivamente as circunstâncias de vida individual e familiar. $O$ impacto da situação é simbolizado como se estivessem vivendo um desastre na vida familiar, diante da desintegração que provoca entre a história, a identidade construída e a perda simbólica do futuro sonhado. A situação gera rupturas nos sistemas de significados e expõe a fragilidade sistêmica da unidade familiar, diante da necessidade de definir uma nova realidade de vida que excede suas capacidades de assimilação e não se releva de imediato.

O projeto que atribuía sentido e aportava à vida familiar é transformado pela circunstância e passa a ficar localizado em um tempo passado. A vida familiar passa a ser controlada pela trajetória da doença. $O$ futuro é visto como ameaçador e o tempo familiar passa a ser dimensionado em função dos acontecimentos que acompanham a doença, frente às indicações que os pais fazem para si mesmos, que precisam agir no 
sentindo de preservar a vida da criança que traz em si o significado de submetendo-se ao tempo da doença.

A situação desorganiza o espaço relacional familiar, colocando os indivíduos que integram o grupo em interação com sistemas e culturas de cuidado, objetos sociais, que alteram a lógica simbólica para o desempenho de papéis. Dessa forma, ao engajar no processo ASSIMILANDO A CONDIÇÃO DE VIDA os indivíduos que compõem o sistema familiar são introduzidos em uma experiência de socialização e trazem para a situação suas perspectivas, suas experiências passadas, seus padrões de relação, seus símbolos, selfs, mentes e habilidades para assumir e desempenhar papéis. A assimilação da condição de vida tem o potencial, tanto para amenizar, quanto para potencializar os conflitos entre a perda simbólica do futuro sonhado e a realidade de vida.

A forma como o grupo familiar se organiza e as atitudes empreendidas para assimilar a condição de vida podem gerar, tanto perspectivas partilhadas e a preservação da figura do outro generalizado determinante para a cooperação e preservação da cultura nas relações familiares SENTINDO-SE CAPAZ DE LIDAR COM A SITUAC̣ÃO, quanto gerar diferentes perspectivas dentro do grupo familiar, o que acentua 0 conflito nas relações familiares e o sentimento de ameaça ao projeto de vida SENTINDO-SE INCAPAZ DE LIDAR COM A SITUAC̣ÃO.

Desse modo, a capacidade como produto da interação simbólica que ocorre no interior dos indivíduos e entre estes e seus mundos sociais é consequência do modo como cada grupo familiar assimila sua condição e elabora suas possibilidades de vida. Assim, SENTINDO-SE CAPAZ PARA LIDAR COM A SITUAÇÃO reflete forças desenvolvidas na interação simbólica, como SENTINDO-SE INCAPAZ PARA LIDAR COM A SITUACÃO reflete potencialização das fragilidades existentes na vida familiar. 


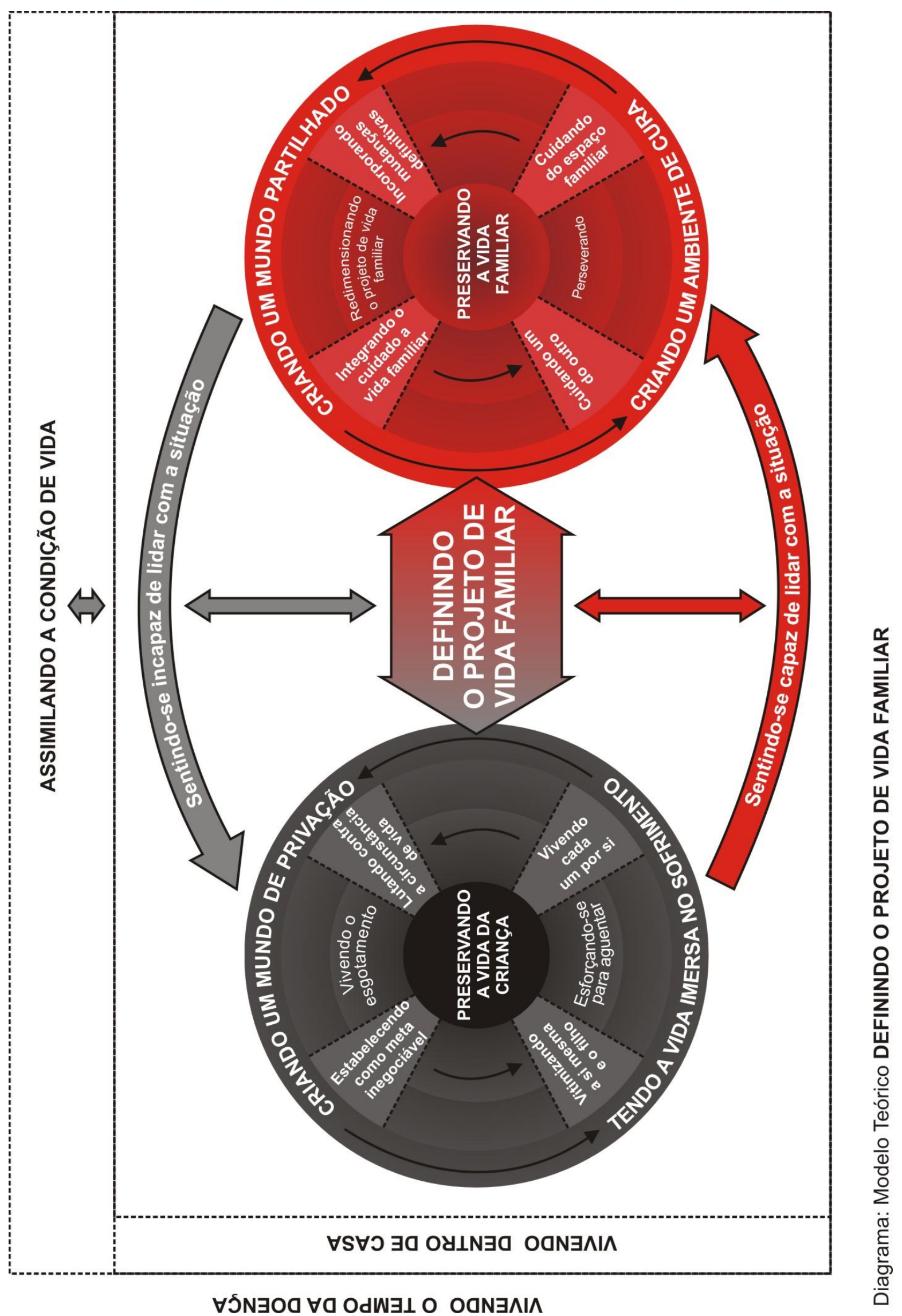


O sentimento de capacidade ou incapacidade de lidar com a situação influencia a maneira como os indivíduos e grupos familiares seguem suas vidas, DEFININDO O PROJETO DE VIDA FAMILIAR em função das ações e das interações interpretadas e orientadas às metas pré-estabelecidas, que ordenam a cena do cuidado e a vida privada.

O processo DEFININDO O PROJETO DE VIDA FAMILIAR integra dois fenômenos representativos dos movimentos dos indivíduos e grupos familiares, a partir das perspectivas utilizadas para definir a situação, simbolizados na experiência interacional da família como PRESERVANDO A VIDA DA CRIANCCA e PRESERVANDO A VIDA FAMILIAR que refletem as decisões $e$ as ações familiares que conduzem a diferentes padrões interacionais de organização da vida familiar, na experiência de transição para o cuidado domiciliar da criança com necessidades especiais de saúde.

PRESERVANDO A VIDA DA CRIANCA representa a forma como o sistema familiar se organiza, tendo como meta única e inegociável a preservação da vida da criança. A centralização e o contínuo movimento PRESERVANDO A VIDA DA CRIANCA, em detrimento da vida individual e familiar, reflete uma decisão que ocorre quase sempre por via da perspectiva materna, que integra uma série de projeções simbólicas catastróficas, que refletem a dificuldade materna de internalizar a condição de vida da criança, sua própria e da família. O padrão de organização PRESERVANDO A VIDA DA CRIANCCA reflete a ausência de perspectivas partilhadas e de ações cooperativas simbólicas, direcionadas à solução dos problemas que acompanham a circunstância de vida. Ao agir simbolicamente ESTABELECENDO COMO META ÚNICA E INEGOCIÁVEL, a mãe impõe um padrão de comportamento derivado da forma como define a situação para si, que nem sempre é aceito pelos demais membros da família. A contínua centralização da mãe em preservar a vida da criança é um padrão mobilizado pelas indicações maternas em direção para seu self, vendo-se apenas como mãe, assumindo para si a responsabilidade integral pelo cuidado e não aceitando a condição de vida da criança, que reflete sua dificuldade de internalizar a condição de vida da criança, como parte da 
construção de sua identidade materna e representada na ação simbólica LUTANDO CONTRA A CIRCUNSTÂNCIA DE VIDA. Estabelecer o cuidado como meta inegociável e lutar contra a circunstância de vida se torna um movimento materno cíclico e fechado, refletido simbolicamente no processo CRIANDO UM MUNDO DE PRIVAÇÃO, representativo das barreiras simbólicas geradas pela mãe que a aprisionam na relação de cuidado do filho doente e, ao mesmo tempo, não permitem espaço para o convívio familiar e a visualização das demandas de cuidado pessoais e dos demais membros da família. A criação de um mundo de privação tem como consequências VIVENDO O ESGOTAMENTO e ESFORÇANDO-SE PARA AGUENTAR. Ao criar barreiras para a conexão e comunicação, os problemas e a sobrecarga são potencializados. As ações são interpretadas como inefetivas $e$, diante da percepção de incapacidade de autodirecionamento, o esforço é direcionado a aguentar. A contínua ausência de negociação de perspectivas, papéis e expectativas de vida familiar conduz a ações isoladas: VIVENDO CADA UM POR SI, que expressa a consequência da ausência de ações cooperativas simbólicas direcionadas à solução dos problemas. A fragmentação da vida familiar é vista como uma experiência desoladora e a mãe se torna vítima de suas próprias ações e das ações dos outros. Ao assumir o lugar de vítima, age VITIMIZANDO O FILHO E A SI MESMA, o que contém, em seu simbolismo, as dimensões do sofrimento materno e o potencial de transformar o espaço familiar em um ambiente de intensa tristeza, angústia e sofrimento sentidos por todos que partilham da vida familiar. As ações isoladas, VIVENDO CADA UM POR SI e VITIMIZANDO A SI MESMA E O FILHO, potencializam o sofrimento e assumem a expressão simbólica: TENDO A VIDA IMERSA NO SOFRIMENTO, diante da dificuldade dos indivíduos em estabelecerem estratégias efetivas de enfrentamento.

PRESERVANDO A VIDA FAMILIAR representa o movimento e forma como o sistema familiar se organiza, ao estabelecer como meta, preservar a vida familiar. O padrão interacional PRESERVANDO A VIDA FAMILIAR reflete a capacidade individual e coletiva para lidar com a situação, como um 
produto de perspectivas internalizadas e partilhadas, que permite, tanto a preservação, quanto a ampliação dos referenciais simbólicos para o desempenho de papéis expressa nas ações INTEGRANDO O CUIDADO À VIDA FAMILIAR e INCOPORANDO MUDANÇAS DEFINITIVAS, diante da percepção que as mudanças na vida familiar são definitivas e devem ser internalizadas como parte da construção de seus papéis, identidades e funções. As ações cooperativas simbólicas, direcionadas à solução dos problemas são refletivas no processo CRIANDO UM MUNDO PARTILHADO, que representa a abertura para a comunicação, que permite a constante negociação de ações e expectativas e também potencializa os recursos, ampliando as visões e a capacidade de resolução dos problemas. Criar um mundo partilhado é uma estratégia interacional simbólica que permite o senso de autodirecionamento na situação vivenciada, expresso nas ações e movimentos REDIMENSIONANDO O PROJETO DE VIDA FAMILIAR e PERSEVERANDO, secundários a constante geração de significados efetivos, diante das dificuldades e do sofrimento que impelem o sistema familiar a prosseguir sua trajetória de vida. As ações cooperativas direcionadas para PRESERVAR A VIDA FAMILIAR revelam a dimensão simbólica do cuidado, expressa no processo CRIANDO UM AMBIENTE DE CURA, que representa o envolvimento cooperativo do sistema familiar, de forma a promover a cura para o sofrimento, mediante o cuidado um do outro e o cuidado do espaço relacional familiar.

Assim, o movimento simbólico da família DEFININDO O PROJETO DE VIDA FAMILIAR assume direções diferenciadas a depender da forma como a família vinha construindo sua história e organizando o viver, além de como reinterpreta seus valores, lutas e sacrifícios e define a circunstância vida, gerada pela situação de ter uma criança com necessidades especiais de cuidado.

No movimento DEFININDO O PROJETO DE VIDA FAMILIAR, que conduz ao PRESERVANDO A VIDA DA CRIANÇA, pode representar um padrão inicial de adaptação à circunstância de vida ou à reprodução de padrões organizacionais e esquemas de referência simbólicos da cultura 
hospitalar, enquanto que o movimento que conduz ao PRESERVANDO A VIDA FAMILIAR pode representar um padrão adaptativo e a preservação dos esquemas de referência simbólicos que integram a cultura familiar.

O processo DEFININDO O PROJETO DE VIDA FAMILIAR é dinâmico, em sua essência, e representa 0 movimento e o padrão de enfrentamento familiar na transição para o cuidado domiciliar, que podem sofrer alterações em função da instabilidade da vida familiar e da constante necessidade de interpretação, definição e ação no sentido de manter o funcionamento adaptativo efetivo. 
Discussão dos resultados

\section{CAPÍTULO V}




\subsection{RECONTEXTUALIZANDO A COMPREENSÃO DA EXPERIÊNCIA DA FAMÍLIA}

A compreensão sobre a experiência da família, que fora obtida nesse estudo, permitiu aprender e apreender a transição para o cuidado domiciliar da criança com necessidades especiais de saúde como um processo interacional simbólico e sistêmico. $\mathrm{O}$ estudo procurou entender a maneira pela qual a família como um sistema atua frente às mudanças nas circunstâncias de vida dela e se organiza para viver com a criança com necessidades especiais de saúde em seu próprio ambiente. A interpretação do processo vivido pela família possibilitou a construção de um modelo teórico representativo de padrões de interação familiar a partir dos significados simbólicos atribuídos à experiência.

Acredita-se que o modelo teórico traz contribuições para 0 conhecimento sobre a família, permitindo a compreensão de distintos padrões de interação que refletem o funcionamento familiar interno e revelam os modos como os sistemas familiares ordenam seu universo simbólico e constroem sua realidade a partir do significado que atribuem à situação, as ações e interações delas e a própria trajetória de vida.

O modelo permite pensar a família desse modo. Os padrões de interação familiar revelados na situação de viver com a criança com necessidades especiais permitem um olhar para a subjetividade, a recursividade e a complexidade presente no contexto da vida familiar, cujos conceitos como vulnerabilidade, resiliência, enfrentamento e apoio social se integram e atuam de forma dinâmica.

Ao se compreender a narrativa familiar como um sistema constituído por atores ou personagens engajados em conversações, ações e contextos, incluindo cenários nos quais transcorrem ações, histórias e contextos prévios ligados entre si pela trama narrativa ${ }^{(135)}$, entra-se no mundo da complexidade e da riqueza da vida familiar. A trama narrativa estabelece a relação entre os atores, a história e o contexto de tal modo que toda 
mudança nos atores altera a história, assim como toda mudança na história altera os atores e toda a mudança no contexto altera a natureza dos atores e de suas histórias. Essa trama narrativa, que integra atores, contextos e histórias, possui corolários morais (propõe vítimas, vilões, heróis), corolários interpessoais (com quem, como e por quais motivos a pessoa se conecta) e corolários comportamentais (a pessoa fundamenta sua conduta nessas histórias, que operam como guias bem como contextos de justificação). Tais corolários, por sua vez, reconstituem, reconfirmam e solidificam a história, compondo o "sistema narrativo".

As histórias que as pessoas contam não operam isoladas de seu entorno, existe uma imensa "ecologia de histórias", que vai desde a relação entre as histórias da experiência pessoal e familiar, partilhadas ou não com seus significativos, até histórias que constituem o patrimônio da cultura e subcultura familiar. $O$ olhar para a família como sistema que tem uma história construída e em constante reconstrução requer o reconhecimento de constelações de histórias que afetam e são afetadas, mutuamente ${ }^{(135)}$.

A narrativa da família sobre sua experiência de doença e transição para o cuidado domiciliar da criança revelou-se parte de uma supra-história de vida, simbolizada pelo movimento de construção do projeto de vida familiar, que abarcam histórias de forças e de fragilidades, de lutas e de sacrifícios, de sonhos e de sofrimento, interconectando-se com os significados simbólicos atribuídos à incidência da doença como um evento que transforma de forma definitiva as circunstâncias e sua trajetória de vida.

Nesse sentido, olhando-se para o sistema familiar sob uma perspectiva desenvolvimental, destaca-se aqui o impacto do processo de migração no ciclo de vida familiar e suas possibilidades de reestruturação das relações familiares frente a vivencia da situação de doença da criança. No presente estudo, esse aspecto da história de vida da família revelou-se como uma fragilidade vivida quando a família não encontra os meios para a reconstrução de sua rede de apoio social e de reconexão com sua rede familiar que funcionaria como fonte primária para o fortalecimento da identidade, da cultura e dos processos de enfrentamento. Aspectos estes 
que, por sua vez, dificultam a organização familiar de forma a integrar as mudanças e desafios gerados pela doença e a cronicidade do evento na vida familiar.

Em total acordo com a literatura nacional ${ }^{(136)}$ e internacional ${ }^{(135,137)}$, a migração provoca um impacto decisivo no ciclo vital da família, tendo consequências variadas, tanto em termos de comportamento individual de seus integrantes, afetando o processo saúde-doença, quanto em termos da configuração das relações, principalmente no sentido de dar novos significados e gerar referências de ação e comunicação entre os membros do sistema familiar.

O ciclo vital é um conceito integrador das fases e etapas dos indivíduos que constituem uma família ${ }^{(138)}$, evidenciando a trama relacional deles através dos tempos, conectando as distintas gerações que a compõe (139). Assim, cada família constrói sua história e tal processo de construção da realidade se dá no dia a dia, ao longo do ciclo vital ${ }^{(140)}$.

O estresse familiar geralmente é maior nos períodos de transição de um estágio para outro no processo de desenvolvimento familiar, pois gera mudanças na percepção que as pessoas têm de si mesmas e dos outros com quem interagem, bem como das relações que estabelecem com outros significativos ${ }^{(138)}$.

Apesar de ser considerado um ciclo vital a parte ${ }^{(138)}$, a migração se converteu em uma transição normativa. No entanto, a análise da dinâmica familiar que se segue à migração releva que o estresse pessoal e os conflitos familiares são consequências inevitáveis desse processo, visto ser uma transição que gera tensões extremas e impacta de forma central na saúde física e mental dos indivíduos ${ }^{(135)}$. Ao migrarem, os indivíduos perdem seus referenciais emocionais e funcionais, suas necessidades aumentam fortemente, ao passo que sua rede social de apoio se fragmenta e fica extremamente perturbada; além disso, as necessidades pessoais ficam apenas parcialmente satisfeitas, tanto ao se considerar o contexto das relações familiares, quando a família migra em conjunto, quanto às novas relações. 
É importante destacar que estudos que abordam a relação entre migração e processo saúde-doença ainda se limitam a contextos internacionais. A relação entre migração, saúde e estresse familiar, abordada na literatura nacional, releva que entre eles existem níveis significativos de estressores mais elevados entre populações migrantes quanto comparados com populações não migrantes ${ }^{(141)}$. Em concordância com essa evidência, o estudo sobre o processo migratório e a condição de saúde da criança acrescenta que diversas circunstâncias familiares como competência, organização ou desorganização, características de hierarquia e qualidade dos relacionamentos, tanto no sistema familiar quanto em seu contexto, influenciam a condição de saúde ${ }^{(142)}$.

De acordo com Wright e Leahey ${ }^{(1)}$, a experiência de migração não é causal em cuidados de saúde, mas, sim, central. Aqui, questões como sobrevivência econômica, mudanças na família extensiva e sistemas de apoio, bem como valores associados ao trabalho e à carência afetiva, foram fatores intervenientes na forma pela qual determinados grupos migrantes enfrentam o evento crônico da doença. Também foi possível perceber que, com o tempo, estes grupos familiares podem tanto integrarem-se como isolarem-se da comunidade na qual se inserem, evidenciando tanto as forças quanto a fragilidade da estrutura familiar.

Outro aspecto relevante de ser destacado é reconhecimento do contexto sociocultural nas quais as famílias se inserem e suas ligações com o modo pelo qual as famílias encontram significado e se organizam para viver com a condição da criança.

As crenças têm sido referidas como diretamente associadas ao nível de sofrimento ${ }^{(143)}$ e a classe social como o principal modelador dos valores e sistemas de crenças da família ${ }^{(1)}$. O significado que os indivíduos atribuem aos fatos da vida, ao estilo de vida, ao emprego, à moradia, ao casamento e à criação dos filhos revelaram-se influências na interação da família e na expressividade do cuidado.

A combinação de estressores econômicos, sociais e emocionais, pode tornar as famílias sobrecarregadas e desestabilizadas, especialmente diante de uma situação de crise, quando a família se vê atingida por 
pressões internas e externas para as quais não tem controle e que oprimem seu funcionamento ${ }^{(24)}$. Cabe destacar que as diferenças intrafamiliares em relação à classe social aqui estudadas atuaram tanto para impulsionar quanto para impedir o enfrentamento efetivo do sistema familiar, especialmente no que se refere ao sistema de crenças e padrões de afetividade familiar.

Nesse sentindo, concorda-se com a definição de cultura familiar apresentada por Elsen ${ }^{(122)}$, que diz que a família, em seu processo de viver, constrói um mundo de símbolos, significados, valores, saberes e práticas, em parte oriundos de sua família de origem, de seu ambiente sociocultural e, em parte, do viver e conviver da nova família em suas experiências e interações cotidianas. Esse mundo de significados é próprio de cada família, muito embora contenha elementos do contexto no qual ela está inserida.

Historicamente, a família tem sido reconhecida como uma unidade social que atua mediando crenças e tradições de uma geração para a outra. Isso inclui a transmissão de crenças e práticas em relação à saúde, à doença e à condição crônica. As tradições, em si, dão à família um senso de estabilidade, de suporte, orientação e significado de enfrentamento frente aos problemas da vida diária ${ }^{(144)}$.

No que se refere à resolução dos problemas e ao manejo da vida diária quando a criança tem uma doença ou disfunção crônica, a cultura familiar exerce influência em dois níveis do processo de avaliação do estresse envolvidos na adaptação familiar: os esquemas de referência e os paradigmas da família. Esses processos da vida familiar são os modos pelos quais a família atribui significado ao fato de ter uma criança com doença crônica e desempenham um papel fundamental na elaboração de respostas e estratégias da família, tanto no início quanto no seguimento domiciliar do cuidado e tratamento médico ${ }^{(144)}$.

Os esquemas de referência e os paradigmas provêem proteção e, no caso da doença crônica, ajudam a unidade familiar a determinar estratégias de enfrentamento. Os esquemas de referência consistem nos valores e convicções fundamentais da família, enquanto que os paradigmas 
guiam diferentes aspectos da vida familiar, tal como a relação matrimonial, a parentalidade, o trabalho e a família, as relações intergeracionais e o cuidado de saúde. Ambos (esquemas de referência e paradigmas) atuam de forma a orientar e sustentar o funcionamento familiar ${ }^{(144)}$.

Articulando-se a abordagem de sistemas ao desenvolvimento da família ${ }^{(145)}$, pode-se observar a relatividade de gênero, de cultura, de transições, de recursos e de dimensões e processos familiares que se estabilizam e se modificam em função das circunstâncias de vida. Os padrões de organização familiar para viver com a condição crônica da criança, aqui identificados, revelam tanto padrões de continuidade quanto padrões de mudança de comportamento, aprendidos ou reproduzidos na experiência de doença, e determinam os diferentes movimentos do grupo familiar para se adequar à situação em questão.

A partir daí, pode-se concluir que a cultura influencia 0 funcionamento familiar dos mais variados modos. Neste estudo, os padrões de interação familiar, os modos como a família organiza a vida e o ambiente doméstico, a estrutura familiar e a dinâmica estabelecida entre a família e a comunidade têm íntima relação com a história, a cultura e o contexto de vida da família.

Ao articular-se o padrão de interdependência identificado como um modo de organização que permita a preservação da vida familiar aos conceitos interacionistas de sociedade e de ação cooperativa simbólica ${ }^{(5)}$, pode-se afirmar que é a interdependência que existe na ação dos indivíduos, ajudando-se a resolver os problemas que estejam enfrentando, o que permitirá a estabilidade e a continuidade da vida familiar.

Por meio da experiência, percebe-se que esse padrão de comportamento manifesta-se como um modo de organização familiar característico do viver de determinadas famílias e se mantém na situação de doença pela contínua interação simbólica partilhada, que permite aos indivíduos que compõe o sistema familiar interpretar e definir suas situações de forma a gerar uma perspectiva comum a todo o grupo familiar e, desse modo, alinhar suas ações a partir dessa definição, agir de forma cooperativa 
para a resolução dos problemas e, constantemente, desempenhar a habilidade para assumir papéis, o que permitirá a construção de uma realidade de vida partilhada.

A interdependência entre o sistema familiar e os sistemas comunitários, os quais incluem a rede de vizinhos, parentes, outras famílias de crianças com necessidades, também se apóia no conceito de ação cooperativa simbólica. O que leva a se pensar nos conceitos de apoio social e de resiliência como uma qualidade sistêmica e interacional que integra esse padrão de interação familiar.

Como apontado por Walsh ${ }^{(24)}$, a resiliência é forjada pela abertura às experiências de vida e à interdependência com outras pessoas. $\mathrm{Na}$ construção da resiliência, os esforços são direcionados a integrar a plenitude da experiência de dor e sofrimento como parte da identidade individual e coletiva, o que influenciará a maneira pela qual vida familiar será seguida.

As estratégias "criando um mundo partilhado" e "criando um ambiente de cura" refletem as ações cooperativas simbólicas, o padrão de enfrentamento instituído como forma de lidar com o sofrimento, proteger a unidade familiar e potencializar os recursos, os quais, por sua vez, permitem a coesão e a continuidade da vida familiar.

Desse modo, o apoio social situa-se na dimensão interpessoal ${ }^{(146)} \mathrm{e}$ integra um processo interacional que tem efeitos comportamentais e emocionais positivos, tanto para o sujeito que recebe quanto para aquele que oferece apoio, permitindo que ambos tenham mais controle sobre suas vidas.

Relacionando-se o conceito de resiliência e apoio social a uma perspectiva sistêmica, ambos podem ser compreendidos como um resultado das relações familiares. As famílias resilientes não apenas obtém apoio social de suas comunidades, mas também correspondem ao devolverem tal apoio à comunidade ${ }^{(147)}$.

A rede social desempenha função estruturante para as relações familiares, especialmente na situação de doença crônica e de imobilidade, 
como é o caso das famílias que cuidam de crianças com necessidades especiais em seus domicílios. As relações sociais contribuem para dar sentido à vida. As habilidades sociais podem ser aprendidas em um contexto de apoio e estímulo a fim de que novos vínculos sejam criados e mantidos ao longo do tempo e das circunstâncias de vida ${ }^{(135)}$.

O agir cooperativamente como um modo que permita ações de cuidado, de amparo e de manutenção da coesão do grupo familiar também fora identificado em outro estudo com famílias na situação de adoecimento crônico, como um modo de agir de maneira inerente à história de vida do grupo estudado ${ }^{(148)}$.

Outra evidência relacionada ao conceito de ação cooperativa simbólica como um aspecto central para a compreensão do funcionamento do sistema familiar na situação de doença leva a defender-se a ideia de que o individualismo e o senso de independência dentro do sistema familiar e entre os sistemas comunitários geram impedimentos para a plena ajuda mútua e para o agir cooperativamente para a resolução dos problemas.

O padrão de interação familiar que tem como foco preservar a vida da criança manifesta-se como uma reprodução de padrões de comportamento prévios ao evento de doença e a resistência para se incorporar padrões alternativos. Enquanto a vida da criança é preservada na interação simbólica estabelecida entre a mãe e a criança, a vida familiar se fragmenta.

A ausência de perspectivas partilhadas e de compreensão mútua sobre os problemas não permite, por sua vez, que os indivíduos alinhem suas ações às dos outros com quem convivem, o que conduz a ações isoladas e à construção de distintas realidades simbólicas de vida.

A ausência de ações cooperativas simbólicas é expressa no padrão de comportamento instituído pela mãe que "cria um mundo de privação" e aprisiona-se na relação de cuidado com o filho, não permitindo a visualização de alternativas para a resolução dos problemas e que acaba por conduzir a um intenso sofrimento e sobrecarga de todos os membros da família. A situação de vulnerabilidade ${ }^{(149)}$ é perpetuada pelo sentimento 
ameaça ao projeto de vida e de incapacidade para lidar com a situação que se apresenta.

Esse padrão de comportamento é reforçado pelo sistema de cuidado de saúde, cujo foco é o preservar a vida da criança, e depositam sobre a mãe o papel de cuidadora, fragmentando, assim, a unidade familiar especialmente no que se refere à aquisição de preparo para viver com a criança no domicílio.

Corroborando com essa evidência, outros estudos desenvolvidos com famílias de crianças com necessidades especiais têm apontado que as mulheres, influenciadas por matrizes socioculturais da socialização no contexto da família e da sociedade e atendendo ao legado da obrigação moral, assumem o papel de cuidadoras e desenvolvem um cuidado solitário e solidário ${ }^{(150)}$. Ao mesmo tempo em que a relação de subordinação as isolam socialmente, tornando-as vulneráveis em sua dimensão afetiva, as empoderam no nível individual para prover o cuidado. Tais mulheres vivem um ciclo de opressão e estresse que compromete seu bem-estar ${ }^{(150)}$.

A forma como as mães enfrentam a situação apoia-se, fundamentalmente, em moderadores da cultura e de gênero como o "mito da boa mãe" que, quando mais dedicada e for, mais será reconhecida pela sociedade, que a valoriza em sua condição materna e não feminina ${ }^{(150)}$. $O$ cuidado materno como meio de garantir a sobrevivência da criança com doença crônica é, também, apontado como uma crença que sustenta os comportamentos de dedicação e envolvimento absoluto da mãe ${ }^{(151)}$.

Apesar das mudanças nos papéis e responsabilidades familiares, o cuidado familiar continua associado à mulher ${ }^{(92)}$. Cabe a mulher desempenhar as tarefas invisíveis e não remuneradas que ocorrem no interior da casa ${ }^{(152)}$. Na situação de cuidado domiciliar da criança com necessidades especiais de saúde, a associação do cuidado à mulher impacta de forma expressiva no funcionamento familiar, provocando um desajuste entre as complexas demandas de cuidar da criança e demais dimensões da vida familiar ${ }^{(92)}$. 
A complexidade da situação de viver com uma criança que tenha uma doença grave, dependente de tecnologia e de cuidados altamente especializados e contínuos como uma condição de sobrevivência está articulada à história, à cultura e ao contexto de vida da família e nos termos de suas capacidades de absorver os desafios trazidos por tal situação.

As narrativas das famílias relevam que o impacto da doença assume proporção de um desastre na vida familiar. No entanto, algumas famílias desenvolvem comportamentos de enfrentamento que possibilitam a restauração, enquanto outras potencializam o impacto.

O comportamento de enfrentamento é compreendido como um esforço específico (encoberto ou manifesto) desempenhado pelos membros individuais da família, ou a família como um todo, para reduzir ou manejar uma demanda no sistema familiar ou para trazer recursos para trabalhar melhor a situação ${ }^{(153)}$. Assim, o enfrentamento envolve os domínios cognitivo, comportamental e interpessoal como um padrão partilhado pelo sistema familiar.

Os diferentes padrões de interação familiar identificados no estudo permitem olhar para os esforços empreendidos pelo sistema familiar, mesmo em meio ao sofrimento e a incerteza, por suas linhas de ação a partir dos focos e metas que estabelecem e as conseqüências na vida familiar.

Poucos estudos de famílias que cuidam de crianças com necessidades especiais de saúde têm focalizado, especificamente, sobre a intersecção de aspectos do funcionamento familiar. Entretanto, estudos que abordem a vida familiar no contexto da doença crônica da criança descrevem distintos padrões de manejo da doença ${ }^{(154,155)}$. Tais padrões identificam como a família, como uma unidade, responde à doença e como incorpora a doença e o tratamento à vida familiar, tendo como foco o componente comportamental. As autoras identificaram cinco tipos de manejo: prosperando, acomodando, suportando, lutando e debatendo-se, os quais refletem diferentes níveis e fontes de dificuldades vivenciados pela família com uma criança com doença crônica para normalizarem suas vidas. 
A normalização caracteriza-se como um processo adaptativo. No entanto, muitas famílias são incapazes de normalizar suas vidas e vivenciam extrema dificuldade em incorporar o manejo da doença em uma rotina familiar estável. Nessas famílias, a doença permanece como um indesejável foco da vida familiar ${ }^{(95)}$. Associada a esse aspecto, a incerteza em relação ao curso de uma doença grave pode atuar como uma séria ameaça aos esforços da família para minimizar a invasão da doença e normalizar a vida familiar $^{(156-158)}$.

Acredita-se que os resultados integram conceitos trabalhados individualmente nas pesquisas com famílias e que ajuda a pensá-los sob o ponto de vista da complexidade. Também permite pensar nos padrões de causalidade circular ${ }^{(159)}$ presentes nos comportamentos familiares, trazendo idéias de como determinados ciclos comportamentais prejudiciais que conduzem os sistemas familiares ao esgotamento podem ser quebrados ou prevenidos.

O modelo apresentado destaca as forças e as fragilidades que influenciam o enfrentamento do sistema familiar as quais foram desenvolvidas ou potencializadas frente às dificuldades. Evidencia a capacidade de o sistema familiar trabalhar em conjunto para a proteção de seus membros, de se beneficiar das relações e recursos e, também, contribuir dentro do contexto no qual vivem. O modelo permite relacionar crenças, estratégias de resolução de problemas e suporte social como processos que influenciam a adaptação familiar ${ }^{(24)}$.

A compreensão dos padrões interacionais e suas intersecções permitem a proposição de intervenções com família, articuladas a problemas específicos em um contexto de vida particular, bem como orientado para as forças e recursos e para o potencial de cada família.

Acredita-se que o presente trabalho acrescentou contribuições para a abordagem do fortalecimento familiar ${ }^{(24,160)}$. Quando se amplia as evidências de que as famílias têm força, habilidade e capacidade para crescerem, se reestruturarem e tornarem-se cada vez mais competentes em viver com a doença, tornam-se visíveis seus esforços e suas áreas de 
dificuldades. A colaboração e parceira entre família como uma unidade de cuidado e os profissionais de saúde têm efeitos sobre o senso de capacidade da família para lidar com a situação, sobre a habilidade para reorganização de papéis e responsabilidades dentro do sistema familiar, sobretudo no que tange à preservação da vida familiar.

\section{Considerações e implicações deste estudo}

O modelo apresentado neste estudo retrata a realidade da vida familiar com a criança com necessidades especiais de saúde, provendo uma estrutura para conhecer as experiências das famílias a partir da forma como estas constroem seu mundo, como enfrentam e se adaptam aos desafios cotidianos e como encontram a cura para o sofrimento. Também propiciou uma maneira de auxiliar na forma como olhar para aquelas famílias que estão com suas vidas imersas no sofrimento e que precisam de ajuda para seguirem em frente.

Reconhece-se os esforços valiosos dos profissionais que promovem e fortalecem as competências das famílias e as preparam para assumir o cuidado da criança no domicílio. Entretanto, acredita-se que seja possível implementar novas ações e ampliar o olhar para a família.

Por acreditar-se que o modelo possa contribuir para Pensar a Família na prática clínica, à medida que se incorpora essa perspectiva, passou-se a olhar para dentro da vida familiar, com todas as suas tensões, ambiguidades e aprendizados profundos. Pensar a Família significa compreendê-la como um sistema em interação e que tal interação é fundamental para sua coesão interna e preservação da própria vida familiar. Assim, o cuidado deve ser centrado na família e envolve muito mais que o treinamento dos pais para assumirem o cuidado da criança no domicílio.

Nesse sentido, o modelo teórico possibilitará um caminho para a compreensão e intervenção sistêmica com a família, a fim de se alterar o próprio movimento dela: de um mundo de privação e sofrimento para um partilhado e de cura. O modelo é um convite que precisa ser experimentado 
na prática para, então, avaliar seu potencial de mudança na família, bem como identificar quais as intervenções são efetivas nessa situação particular de vida familiar.

Acredita-se que existam inúmeras implicações para as pesquisas futuras, pois os resultados aqui obtidos proporcionaram a resposta para a pergunta específica, mas, eventualmente, fizeram emergir outras. Por esse motivo é possível perceber que se compartilha a ideia de que o modelo precisa ser testado (seja para contestado ou para validado) e ampliado. $\mathrm{O}$ modelo apresenta um caminho para o fortalecimento da família, mas as intervenções precisam ser desveladas, nomeadas e transformadas em conceitos.

Portanto, ao ter-se claro que o modelo reflete um contexto específico de vida familiar, a aplicação dos conceitos identificados à famílias de diferentes padrões socioculturais poderá contribuir para a validação e ampliação das categorias apresentadas.

Os padrões de interação familiar são dinâmicos em sua essência. Como já dito, o modelo representa um recorte em um momento da trajetória de vida da família e tal recorte acaba por relevar a continuidade e a estabilidade desses padrões. No entanto, uma compreensão mais precisa poderá ser obtida por meio de estudos longitudinais.

Os desafios para a Enfermagem da Família, com relação a esse grupo familiar específico, são inúmeros, quer seja na pesquisa, na prática assim como no âmbito das políticas públicas. Acredita-se que eles estejam interligados e que à medida que se busca dar maior visibilidade aos dilemas e desafios que essas famílias concretamente vivem - dando voz à família poder-se-á influenciar várias outras áreas. 
Referencias 
1. Wright LM, Leahey M. Enfermeiras e famílias: um guia para a avaliação e intervenção na família. São Paulo: Roca; 2008.

2. Bell JM, Wright LM. La recherche sur la pratique des soins infirmiers a la famille [Research on family interventions]. In: Duhamel F. La santé et la famille: Une approche systémique en soins infirmiers [Families and health: A systemic approach in nursing care] 2nd ed. Quebec: Gaetan Morin editeur, Chenelière Éducation, 2007. Chap. 5, p. 87-99.

3. Angelo M. The Emergence of Family Nursing in Brazil. J Fam Nurs. 2008; 14(4): 436-41.

4. Schober M, Affara F. The Family nursing: frameworks for practice. Geneva: International Council of Nurses. 2001.

5. Angelo M. Com a família em tempos difíceis: uma perspectiva de enfermagem [Tese]. São Paulo: Escola de Enfermagem, Universidade de São Paulo; 1997.

6. Pereira WR, Silveira AO. Estudo diagnóstico das condições de atendimento aos direitos da pessoa que procura atendimento em um serviço público hospitalar na cidade de Cuiabá - MT. In: Anais do X Encontro de Iniciação Científica; 2002; Cuiabá - MT. Cuiabá - MT: Ed UFMT, 2002. p. 233.

7. Silveira AO, Gaíva MAM. Preparo de Mães de Recém-Nascidos Prematuros e de Baixo Peso para a Alta: Uma Proposta de Intervenção. [Trabalho de Conclusão de Curso]. Cuiabá (MT): Faculdade de Enfermagem e Nutrição da UFMT; 2002.

8. Gaíva MAM, Neves AQ, Silveira AO, Siqueira FMG. A alta em unidade de cuidados intensivos neonatais: perspectiva da equipe de saúde e de familiares. Rev Min Enf 2006; 10(4): 387-92.

9. Wright LM, Leahey M. Calgary family intervention model: one way to think about change. J Mar Fam Therapy 1994; 20 (4): 381-95.

10. Wright LM, Watson WL, Bell JM. Beliefs: The heart of healing in families and illness. New York: Basic Books; 1996.

11. Von Bertalanffy L. General systems theory: foundations, development, applications. New York: George Braziller; 1968.

12. Blumer H. Symbolic interactionism: perspective and method. Englewood Cliffs: Prentice-Hall; 1969.

13. Thorne S, Robinson CA. Reciprocal trust in health care relationships. J Adv Nurs 1988; 13(6): 782-89.

14. Robinson CA. Nursing interventions with families: a demand or an invitation to change? J Adv Nurs 1994; 19(5): 897-904. 
15. Wright LM, Bell JM. The future of family nursing research: interventions, interventions, interventions. Jap J Nurs Res 1994; 27(2-3): 4-15.

16. Robinson CA, Wright LM. Family Nursing Interventions: What families say makes a Difference. J Fam Nurs 1995; 1(3): 327-45.

17. Silveira AO. Buscando segurança para desenvolver suas competências: a experiência de interação da família [Dissertação]. São Paulo: Escola de Enfermagem, Universidade de São Paulo; 2005.

18. Silveira $A O$, Angelo $M$. A experiência de interação da família que vivencia a doença e hospitalização da criança. Rev Latino-Am Enf 2006; 14(16): 893900.

19. Hopia H, Tomlinson PS, Paavilainen E, Åstedt-Kurki. Child in hospital: family experiences and expectations of how nurses can promote family health. J Clin Nurs 2005; 14(2): 212-22

20. Hopia H, Paavilainen E, Åstedt-Kurki. Promoting health for families of children with chronic conditions. J Adv Nurs 2004; 48(6): 575-83.

21. Bell JM. Process and outcome in family intervention research: Methodological challenges. In: International Nursing Research Conference. Vancouver, British Columbia: Canada; 1994.

22. Bell JM. Advanced practice in family nursing: One view [Editorial]. J Fam Nurs 1996; 2(3): 244-7.

23. Silveira AO, Angelo M, Martins SR. Doença e hospitalização da criança: identificando as habilidades da família. Rev Enf UERJ 2008; 16: 212-7.

24. Walsh F. Fortalecendo a resiliência familiar. São Paulo: Roca; 2005.

25. Angelo M, Fracolli RA. Lives in context: vulnerability of the families of technology-dependent child. In: Conference Book of 8th International Family Nursing Conference. Bangkok, Thailand; 2007; p. 90.

26. McPherson $M$. et al. A new definition of children with special health care needs. Am Acad Pediatr 1998; 102(1): 137-41.

27. Leite NSL, Cunha SR. A Família da Criança Dependente de Tecnologia: Aspectos Fundamentais para a Prática de Enfermagem no ambiente Hospitalar. Esc Anna Nery R Enf 2007; 11(1): 92-7.

28. Neves ET, Cabral IE. A fragilidade clínica e a vulnerabilidade social das crianças com necessidades especiais de saúde. Rev Gaúcha Enf 2008; 29(2): 182-90.

29. Fracolli RA, Angelo M. A experiência da família que possui uma criança dependente de tecnologia. Rev Min Enf 2006; 10(12): 125-31. 
30. Kirk S. Negotiating lay and Professional roles in the care of children with complex health care needs. J Adv Nurs 2001; 34(5): 593-602.

31. Fracolli RA. A experiência da família que possui uma criança dependente de tecnologia [Dissertação]. São Paulo: Escola de Enfermagem, Universidade de São Paulo; 2005.

32. Maltby HJ, Kristjanson L, Coleman ME. The parenting competency framework: Learning to be a parent of a child with asthma. Int $\mathrm{J}$ Nurs Prac 2003; 9(6): 368-73.

33. Omran AR. The Epidemiologic Transition - a Theory of the Epidemiology of Population change. Bull World Health Organ 2001; 79(2): 161-70.

34. Cabral IE. Aliança de saberes no cuidado e estimulação da criança-bebê: concepções de estudantes e mães no espaço acadêmico de enfermagem. Rio de Janeiro: Editora da Escola de Enfermagem Anna Nery; 1999.

35. Cabral IE, Moraes JRMM, Santos FF. O egresso da terapia intensiva neonatal de três instituições públicas e a demanda de cuidados especiais. Esc Anna Nery Rev Enf 2003; 7(2): 211-8.

36. Heller R, Mcklindon D. Families as "faculty": parents educating caregivers about family-centered care. J Pediatr Nurs 1996; 22(5): 428-31.

37. Mentro AM. Health care policy for medically fragile children. J Pediatr Nurs 2003; 18(4): 225-32.

38. Haas DL, Herman BG, Beverly M. Parent/Professional Partnerships in Caring for Children with Special Health Care Needs. Compr Ped Nurs 1992; 15(1): 39-53.

39. Glendinning C, Coleman A, Shipman C, Malbon G. Primary care groups: Progress in partnerships. BMJ 2001; 323:28-31.

40. Dyck PC, Kogan MD, McPherson MG. Prevalence and characteristics of children with special health care needs. Arch Ped Adolesc Med 2004; 158(9): 885-90.

41. Wang KK, Barnard AB. Technology-dependent children and their families: a review. J Adv Nurs 2004; 45(1): 36-46.

42. Heaton J, Noves J, Sloper P, Shah R. Families' experiences of caring for technology-dependent children: a temporal perspective. Health Soc Care Com 2005; 13(5): 441-50.

43. Rehm RS, Bradley JF. Normalization in families raising a child who is medically fragile/technology dependent and developmentally delayed. Qual Health Res 2005; 15(6): 807-20. 
44. Cabral IE, Silva JJ, Zillmann DO, Moraes JR, Rodrigues EC. A criança egressa da terapia intensiva na luta pela sobrevida. Rev Bras Enf 2004; 57(1): 35-9.

45. Vernier ETN, Cabral IE. Caracterização de crianças com necessidades especiais de saúde e seus familiares cuidadores. Santa Maria (RS). 20042005: subsídios para intervenções de enfermagem. Rev Soc Bras Enf Ped 2006; 6(1): 37-45.

46. Hazlett DE. A study of pediatric home ventilator management: medical, psychosocial, and financial aspects. J Ped Nurs 1989; 4(4): 284-94.

47. Cohen $\mathrm{MH}$. The technology dependent child and the socially marginalized family: a provisional framework. Qual Health Res 1999; 9(5): 654-68.

48. Kirk SA. Caring for children with specialized health care needs in the community: the challenges for primary care. Health Soc Care Com1999; 7(5): 350-7.

49. Kirk S, Glendinning C, Callery P. Parent or nurse? The experience of being the parent of a technology-dependent child. J Adv Nurs 2005; 51(5): 45664.

50. Smith SJ. Promoting family adaptation to the at-home care of the technology-dependent child. Compr Ped Nurs 1991, 14(4): 249-58.

51. Wong D. Transition from hospital to home for children with complex medical care. J Ped Onc Nurs 1991; 8(1): 3-9.

52. Lewis CC, Alford-Winston A, Billy-Kornas M, McCaustland MD, Tachman $\mathrm{CP}$. Care management for children who are medically fragile/technology dependent. Com Ped Nurs 1992; 15(2): 73-91.

53. Lewis M, Noyes J. Discharge management for children with complex needs. Ped Nurs 2007; 19(4): 26-30.

54. Hass DL, Gray HB, McConnel B. Parent/professional partnerships in caring for children with special health care needs. Com Ped Nurs 1992; 15(1): 3953.

55. Kirk S, Glendinning C. Trends in community care and patient participation: implications for the roles of informal carers and community nurses in the United Kingdom. J Adv Nurs 1998; 28(2): 370-81.

56. Danvers L, Freshwater D, Cheater F, Wilson A. Providing a seamless service for children with life-limiting illness: experiences and recommendations of professional staff at the Diana Princess of Wales Children's Community Service. J Clin Nurs 2003; 12: 351-59.

57. Hewitt-Taylor J. Caring for children with complex and continuing health needs. Nurs Stand 2005; 19(42): 41-47. 
58. Department of Health. National Service Framework for Children, Young People and Maternity Services: Disabled Children and Young People and Those with Complex Health Needs. London: The Stationery Office; 2004.

59. Lenton S, Franck L, Salt A. Children with complex health needs: supporting the child and family in the community. [Editorial]. Child Care H Dev 2004; 30(3): 191-2.

60. Leal RJ, Cabral IE, Perreault M. Experiência Brasil-Canadá no cuidado social e na saúde da criança com necessidades especiais: aproximações e distanciamentos. Interfaces Brasil/Canadá 2010; 11:95-119.

61. Brasil. Lei no 8.742 de 7 de dezembro de 1993. Dispõe sobre a organização da Assistência Social e da outras providências. Brasília: Diário Oficial [da] República Federativa do Brasil. 8 dez; 1993.

62. Brasil. Lei no 8.080 de 19 de Setembro de 1990. Regulamenta o Sistema Único de Saúde. Brasília: Diário Oficial [da] República Federativa do Brasil. 20 set; 1990.

63. Brasil, Ministério da Saúde. Programa de Saúde da Família. Brasília: COSAC; 1994.

64. Brasil, Ministério da Saúde. Estatuto da Criança e do Adolescente. Lei no 8.069 de 13 de Julho de 1990. Dispõe sobre a proteção integral a criança e ao adolescente. Brasília: Diário Oficial [da] República Federativa do Brasil.16 jul; 1990.

65. Kirk S, Glendinning C. Diving services to support parents caring for a technology-dependent child at home. Child Care H Dev 2004; 30(3): 20918.

66. Sloper P. Models of service support for parents of disabled children. What do we know? What do we need to know? Child Care H Dev 1999; 25: 8599.

67. Aguiar RCB. Saberes e práticas de familiares cuidadores no cuidado à criança em terapia anticonvulsivante: o processo de produção do almanaque [Dissertação]. Rio de Janeiro: Escola de Enfermagem Anna Nery/UFRJ; 2005.

68. Castro EK, Piccinini CA. Implicação da doença orgânica crônica na infância para as relações familiares: algumas questões teóricas. Psicol Refl Crit 2002; 15 (3): 625-35.

69. Glass KC. Ethical issues in neonatal intensive care: perspectives for the neurologist. Sem Ped Neurol 2002; 9(1): 35-40.

70. Glass KC, Carnevale FA. Decisional Challenges for Children Requiring Assisted Ventilation at Home. HEC Forum 2006; 18(3): 207-21. 
71. Sritippayawan S, Kun SS, Keens TG, Davidson WSL. Initiation of home ventilation in children with neuromuscular disorders. J Ped 2003; 142(5): 481-5.

72. Carnevale FA, Rehm RS, Kirk S, McKeever P. What we know (and do not know) about raising children with complex continuing care needs. J Child $\mathrm{H}$ Care 2008; 12(4): 4-6.

73. Carnevale FC, Canouï P, Hubert P, Farrel C, Leclerc F, Doussau A. The moral experience of parents regarding life-support decisions for their critically-ill children: a preliminary study in France. J Child H Care. 2005; 10(1): 69-82.

74. Carnevale FA, Alexander E, Davis M, Rennick J, Troini R. Daily Living With Distress and Enrichment: The Moral Experience of Families with ventilatorassisted children at home. Pediatr 2006; 117(1): 48-60.

75. Gibson B. Long-term ventilation for patients with Duchenne muscular dystrophy: physicians' beliefs and practices. Chest 2001; 119(3): 940-6.

76. McIntosh J, Runciman P. Exploring the role of partnership in the home care of children with special health needs: qualitative findings from two service evaluations. Int J Nurs Stud 2008; 45(5): 714-26.

77. Cohen $\mathrm{MH}$. Ethical issues in discharge planning for vulnerable infants and children. Ethics Behav 1995; 5: 1-13.

78. Noddings N. Moral obligation or moral support for high-tech home care. Hast Cent Rep 1994; 24: 6-10.

79. Davis RH. Home ventilation of a child with motor and sensory neuropathy. BMJ 1996; 313: 153-5.

80. Marcon SS, Waidman MAP, Carreira L, Decesaro MN. Compartilhando a situação de doença: o cotidiano de famílias de pacientes crônicos. In: Elsen I, Marcon SS, Silva MRS. O viver em família e a interface com a saúde e a doença. Maringá: Eduem. 2002; p. 311-36.

81. Guimarães TMR, Miranda WL, Tavares MMF. O Cotidiano das famílias de crianças e adolescentes portadores de anemia falciforme. Rev Bras Hemat 2009; 31(1): 9-14.

82. Franck LS, Callery P. Re-thinking family-centred care across the continuum of children s healthcare. Child Care H Dev 2004; 30(3): 265-77.

83. Wang KW, Barnard A. Caregivers' Experiences at Home With a VentilatorDependent Child. Qual H Res 2008; 18(4): 501-8.

84. Ray LD. Parenting and Childhood Chronicity: Making Visible the Invisible Work. J Ped Nurs 2002; 17(6): 424-38. 
85. Reeves E, Timmons S, Dampier S. Parents' experience of negotiating care for their technology-dependent child. J Child H Care 2006; 10(3): 228-39.

86. Avis $M$, Reardon R. Understanding the views of parents of children with special needs about the nursing care their child receives in hospital: a qualitative study. J Child H Care 2008; 12(1): 7-17.

87. Rempel GR, Harrison MJ. Safeguarding Precarious Survival: Parenting Children Who Have Life-Threatening Heart Disease. Qual H Res. 2007; 17(6): 824-37.

88. Ray L. The social and political conditions that shape special needs parenting. J Fam Nurs 2003; 9(3): 281-304.

89. O'Brien ME. Living in a house of cards: family experiences with long-term childhood technology dependence. J Ped Nurs 2001; 16(1): 13-22.

90. Wilson S, Morse JM, Penrod J. Absolute involvement: the experience of mothers of ventilator-dependent children. H Soc Com 1998; 6(4): 224-33

91. McKeever P, Miller KL. Mothering children who have disabilities: a Bourdieusian interpretation of maternal practices. Soc Sci Med 2004; 59(6): 1177-91.

92. Neves ET, Cabral IE. Cuidar de crianças com necessidades especiais de saúde: desafios para as famílias e enfermagem pediátrica. Rev Eletr Enf. 2009a; 11(3):527-538.

93. Earle EA, Rennick JE, Carnevale FA, Davis GM. 'It's okay, it helps me to breathe': the experience of home ventilation from a child's perspective. Child Care H Dev 2006; 10(4): 270-82.

94. Vieira SS, Dupas G, Ferreira NMLA. Doença Renal Crônica: a experiência da criança. Esc Anna Nery Rev Enf 2009; 13(1): 74-83.

95. Knafl KA, Gilliss CL. Families and Chronic Illness: A Synthesis of Current Research. J Fam Nurs 2002; 8(3): 178-98.

96. Kirk S. Families experiences of caring at home for a technology-dependent child: a review of the literature. Child Care H Dev 1998; 24(2): 101-14.

97. Deatrick JA, Knafl KA, Murphy-Moore C. Clarifying the concept of normalization. J Nurs Sch 1999; 31(3): 209-14.

98. Barnet D, Clements M, Kaplan-Estrin M, Fialka J. Bulding new dreams: supporting parent's adaptation to their child with special needs. Infants and Young Children 2003; 16(3): 184-200.

99. Dyck I, Kontos P, Angus J, McKeever P. The home as a site for long-term care: meanings and management of bodies and spaces. H Place 2005; $11(2): 173-85$. 
100. Thyen U, Kuhlthau K, Perrin JM. Employment, child care and mental health of mothers caring for children assisted by technology. Pediatr 1999; 103(6): 1235-42.

101. Baumgardner DJ, Burtea ED. Quality of life in technology dependent children receiving home care and their families: a qualitative study. WMJ 1998; 97(8): 51-5.

102. Teague BR, Fleming JW, Castle A, Kiernan BS, Lobo ML, Riggs S, Wolfe JG. High tech home care for children with chronic health conditions: a pilot study. J Ped Nurs 1993; 8(4): 226-32.

103. MacDonald $\mathrm{H}$, Callery $\mathrm{P}$. Parenting children requiring complex care: a journey through time. Child Care H Dev 2008; 34(2): 207-13.

104. Guerrero-Gamboa NS. Edificando uma fortaleza: a experiência de pais no cuidado do filho estomizado no Brasil e na Colômbia. [Tese] São Paulo: Escola de Enfermagem, Universidade de São Paulo; 2009.

105. Molinari DL, Freeborn D. Social support needs of families adopting special needs children. J Psyc Nurs Ment H Serv 2006; 44(4): 28-34.

106. Doig JL, McLennan JD, Urichuk L. 'Jumping through hoops': parents' experiences with seeking respite care for children with special needs. Child Care H Dev 2009; 35(2): 234-42.

107. Patterson JM, Leonard BJ, Titus JC. Home care for medically fragile children: impact on family health and well-being. J Dev Behav Ped 1992; 13(4): 248-55.

108. Leonard BJ, Brust JD, Nelson RP. Parental distress: caring for medically fragile children at home. J Ped Nurs 1993; 8(1): 22-9.

109. Raina P, O'Donnell M, Rosenbaum P, Brehaut J, Walter SD, Russell D, Swinton M, Zhu B, Wood E. The health and well-being of caregivers of children with cerebral palsy. Pediatr 2005; 115(6): 626-36.

110. Kuster PA, Badr LK, Chang BL, Wuerker AK, Benjamin AE. Factors influencing health promoting activities of mothers caring for ventilatorassisted children. J Ped Nurs 2004; 19(4): 276-87.

111. Agazio JG. Family Transition through the termination of Private Duty Home Care Nursing. J Ped Nurs 1997; 12(2): 74-84.

112. Brinchmann BS. When the home becomes a prison: living with a severely disabled child. Nurs Ethics 1999; 6(2): 137-43.

113. Angelo M, Bousso RS, Rossato LM, Damião EBC, Silveira AO, Castilho AMCM. Família como categoria de análise e campo de investigação em enfermagem. Rev Esc Enf USP 2009; 43(esp.2): 1337-41. 
114. Charon JM. Simbolic interactionism. $3^{\text {rd }}$ ed. Englewood Cliffs: PrenticeHall; 1989.

115. Mead GH. Mind, Self, and Society from the standpoint of a social behaviorist. Chicago: University of Chicago Press; 1972.

116. Glaser BG, Strauss AL. The discovery of grounded theory. New York: Aldine; 1967.

117. Glaser BG. Theoretical sensitivity. Mil Valley: The Sociology Press; 1978.

118. Charmaz K. A construção da teoria fundamentada: guia prático para análise qualitativa. Porto Alegre: Artmed; 2009.

119. Bell L, Paul D, Tribble DSC. Strategies to elicit and analyze relational family data. J Fam Nurs 2000; 6(4): 380-99.

120. Feetham SL. Conceptual and methodological issues in research of families. In: Bell JM, Watson WL, Wright LM, editors. The cutting edge of family nursing. Alberta; 1990. p.35-49.

121. Friedman MM. Bowden VR, Jones EG. Family nursing research: theory and pratice. 5ed. Upper Saddle River: Prentice Hall; 2003.

122. Elsen I. Cuidado familial: uma proposta inicial de sistematização conceitual. In: Elsen I, Marcon SS, Silva MRS. O viver em família e sua interface com a saúde e a doença. 2 ed. Maringá: Eduen; 2004. p. 11-24.

123. Kleinman A. Patients and Healers in the Context of Culture. Berkeley: University of California Press; 1980.

124. Brasil, Conselho Nacional de Saúde. Resolução no 196 de 10 de outubro de 1996. Estabelece diretrizes e normas de pesquisas envolvendo seres humanos. Brasília: Diário Oficial [da] Republica Federativa do Brasil.16 out; 1996.

125. Frank AW, What Is Dialogical Research, and Why Should We Do It? Qual H Res 2005; 15 (7): 964-74.

126. Rosenblatt PC, Fischer LR. Qualitative Family Research. In: Boss WJ, Doherty WJ, LaRossa R, Schumm WR, Steinmetz SK. Sourcebook of family theories and methods: A contextual approach. New York: Plenum; 1993. p. 167-77.

127. Hewitt J. Ethical Components of Researcher - Researched Relationships in Qualitative Interviewing. Qual H Res 2007; 17(8): 1149-59.

128. Thorne S, Darbyshire P. Land Mines in the Field: A Modest Proposal for Improving the Craft of Qualitative Health Research. Qual H Res 2005, 15(8): 1105-13. 
129. Brasil, Ministério da Saúde. Agência Nacional de Vigilância Sanitária. Resolução da ANVISA $n^{\circ} 11$ de 26 de janeiro de 2006. Dispõe sobre o regulamento técnico de funcionamento de serviços que prestam atenção domiciliar. Brasília: Diário Oficial [da] República Federativa do Brasil. 30 jan.; 2006.

130. Lacerda MR, Giacomozzi CM, Oliniski SR, Truppel TC. Atenção à saúde no domicílio: modalidades que fundamentam sua prática. S Soc 2006; 15(2): 88-95.

131. Glaser BG. Conceptualization: On Theory and Theorizing Using Grounded Theory. Int J Qual Meth 2002; 1(2): 23-38.

132. Minayo MCS. Pesquisa social teoria método e criatividade. Petrópolis: Vozes; 1994.

133. Mayan MJ. An Introduction to Qualitative Methods: A Training Module for Students and Professionals. Canada: International Institute for Qualitative Methodology; 2001.

134. Lofland J, Lofland LH. Analyzing social settings: A guide to qualitative observation and analysis. 3 ed. Belmont: Wadsworth Publishing Co; 1995.

135. Sluzki CE. A rede social na prática sistêmica - alternativas terapêuticas. São Paulo: Casa do Psicólogo; 1997.

136. Mota E, Franco A, Motta M. Migração, estresse e fatores psicossociais na determinação da saúde da criança. Psicol Refl Crit 1999; 12(1): 119-32.

137. Falicov CJ. O significado cultural dos triângulos familiares. In: McGoldrick M. Novas abordagens da terapia familiar: raça, cultura e gênero na prática clínica. São Paulo: Roca; 2003. p. 43-56.

138. Carter B, McGoldrick, M. As mudanças no ciclo da vida familiar: uma estrutura para a terapia familiar. 2 ed. Porto Alegre: Artmed; 2001.

139. Moré CLOO, Queiroz AH. Migração, movimento e transformação: Irrupção do novo nas relações familiares. In: Cerveny CMO. Família e movimento. São Paulo: Casa do Psicólogo; 2007. p. 54-68.

140. Cerveny CMO, Berthoud CME. Família e ciclo vital: nossa pesquisa em realidade. São Paulo: Casa do Psicólogo; 1997.

141. Almeida-Filho N. The psychosocial costs of development: labor, migration and stress in Bahia, Brazil. Latino-Am Rev 1982; 17(3): 91-118.

142. Boyce WT. Social support, family relations and children. In: Cohen S, Syme SL. Social Support and Health. Orlando: Academic Press; 1985. p. 151-73. 
143. Wright LM. One idea for healing families and communities: Soften suffering through spiritual care practices. J Fam Nurs 2008; 14(4): 394411.

144. McCubbin HI, Thompson MA, Thompson Al, McCubbin MA, Kaston AJ. Culture, ethnicity, and the family: Critical factors in childhood chronic illnesses and disabilities. Pediatr 1993; 91(5): 1063-70.

145. Falicov CJ. Immigrant family process. In: Walsh F. Normal Family Process: growing diversity and complexity. 3ed. New York: Guilford Press; 2003. p. 280-300.

146. Pedro ICS, Rocha SMM, Nascimento LC. Apoio e rede social em enfermagem familiar. Rev Latino-am Enf 2008; 16(2): 324-7.

147. Black K, Lobo M. A Conceptual Review of Family Resilience Factors. J Fam Nurs 2008; 14(1): 33-55.

148. Girardon-Perlini NMO. Cuidando para manter o mundo da família amparado: a experiência da família rural frente ao câncer. [Tese]. São Paulo: Escola de Enfermagem, Universidade de São Paulo; 2009.

149. Pettengill MAM, Angelo M. Vulnerabilidade da família: desenvolvimento do conceito. Rev Lat Am Enf 2005; 13(6): 982-8.

150. Neves ET, Cabral IE. Empoderamento da mulher cuidadora de crianças com necessidades especiais de saúde. Tex Cont Enf. 2009b; 17(3): 55260

151. Damião EBC. Crenças da família da criança com fibrose cística. [Tese]. São Paulo: Escola de Enfermagem, Universidade de São Paulo; 2002.

152. Sarti CA. A família como espelho: um estudo sobre a moral dos pobres. 2 ed. São Paulo: Cortez; 2003.

153. McCubbin MA, McCubbin HI. Family coping with health crises: The resiliency model of family stress, adjustment, and adaptation. In: Danielson C, Hamel-Bissel B, Winstead-Fry P. Families, health, and illness. New York, NY: Mosby; 1993. p. 239-306.

154. Knafl K, Breitmayer B, Gallo A, Zoeller L. Family response to childhood chronic illness: Description of management styles. J Ped Nurs 1996; 11(5): 315-26.

155. Knafl KA, Deatrick JA. Further refinement of the family management style framework. J Fam Nurs 2003; 9(2): 232-56.

156. Cohen $\mathrm{MH}$. The unknown and the unknowable: managing sustained uncertainty. West J Nurs Res 1993; 15(1): 77-96. 
157. Dodgson JE, Garwick A, Blozis SA, Patterson JM, Bennett FC, Blum RW. Uncertainty in Childhood Chronic Conditions and Family Distress in Families of Young Children. J Fam Nurs 2000; 6(3): 252-66.

158. Cunha MLR. Incerteza e sacrifício: o sofrimento na vida familiar invadida pelo câncer da criança. [Tese]. São Paulo: Escola de Enfermagem, Universidade de São Paulo; 2009.

159. Bell J. encouraging nurses and families to think interactionally: revisiting the usefulness of the circular pattern diagram. J Fam Nurs. 2000; 6(3): 203-9.

160. Hulme PA. Family Empowerment: A Nursing Intervention With Suggested Outcomes for Families of Children With a Chronic Health Condition. J Fam Nurs 1999; 5(1): 33-50. 
Anexos 


\section{ANEXO 1 - Carta de Aprovação Comitê de Ética}

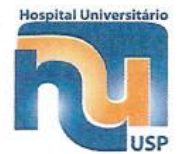

São Paulo, 7 de novembro de 2008.

$I l^{m o(a)} \cdot S^{r(a)}$.

\section{Profa. Dra. Margareth Angelo}

Departamento de Enfermagem Materno-Infantil e Psiquiatria

Escola de Enfermagem

UNIVERSIDADE DE SÃO PAULO

REFERENTE: Projeto de Pesquisa "Intervenções sistêmicas com famílias na transição para o cuidado domiciliar da criança com necessidades especiais de cuidado de saúde" Co-autor(es): Aline de Oliveira Silveira - Registro CEP-HU/USP: 831/08 - SISNEP CAAE: 0043.0.198.196-08

Prezado(a) Senhor(a)

O Comitê de Ética em Pesquisa do Hospital Universitário da Universidade de São Paulo, em reunião ordinária realizada no dia 7 de novembro de 2008, analisou o Projeto de Pesquisa acima citado, considerando-o como APROVADO, bem como o seu Termo de Consentimento Livre e Esclarecido.

Lembramos que cabe ao pesquisador elaborar e apresentar a este Comitê, relatórios anuais (parciais ou final, em função da duração da pesquisa), de acordo com a Resolução 196/96 do Conselho Nacional de Saúde, item IX.2.c.

O primeiro relatório está previsto para 7 de novembro de 2009.

Atenciosamente,

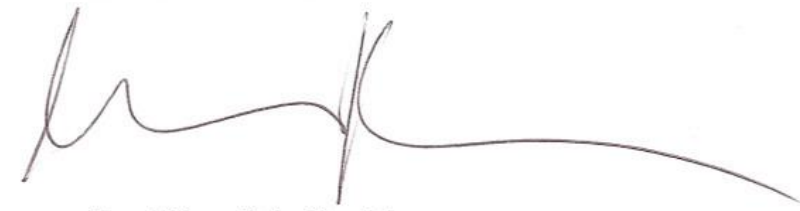

Dr. Maurício Seckler

Coordenador do Comitê de Ética em Pesquisa

Hospital Universitário da USP 


\section{ANEXO 2 - Termo de Consentimento Livre e Esclarecido ${ }^{1}$}

Meu nome é Aline Oliveira Silveira, enfermeira, doutoranda da Escola de Enfermagem da Universidade de São Paulo, sob a orientação da Professora Doutora Margareth Angelo, professora Titular da Escola de Enfermagem da Universidade de São Paulo.

Estou realizando um estudo intitulado "Intervenções sistêmicas com famílias na situação de transição para o cuidado domiciliar da criança com necessidades especiais de cuidado de saúde", que tem como objetivo compreender como as famílias enfrentam e se adaptam a situação de cuidar da criança em casa, e o que ajuda as famílias nessa situação de doença. Esse estudo resultará na elaboração de minha tese de doutorado e os resultados serão divulgados em eventos e publicações científicas.

Para tanto estou realizando entrevistas com as famílias que vivenciam o cuidado da criança com necessidades especiais de cuidado de saúde, que estejam se preparando para a alta hospitalar ou estejam cuidando da criança em casa, e que aceitem voluntariamente contar-me sobre suas experiências de cuidar da criança com necessidades especiais. A entrevista será realizada em local privado, podendo ser solicitada mais de uma entrevista com o mesmo participante. O conteúdo da entrevista será gravado em áudio para posterior transcrição e análise dos dados. As fitas com conteúdo das entrevistas permanecerão guardadas com a pesquisadora, e somente a pesquisadora e a orientadora do estudo terão acesso a seu conteúdo.

Ao participante do estudo será garantido o sigilo das informações, o anonimato, bem como a liberdade para retirar o consentimento a qualquer momento e deixar de participar do estudo, mesmo após ter assinado o termo, sem que isto traga prejuízos à continuidade da assistência prestada à criança e à família. Após a concessão da entrevista, caso desejar que os dados não sejam mais utilizados, poderá contatar a pesquisadora, com a certeza da devolução da fita e destruição da transcrição.O participante do estudo terá direito a receber informações adicionais sobre o estudo a qualquer momento, mantendo contato com a pesquisadora principal.

Caso o participante do estudo for menor de idade, o termo de consentimento deverá ser assinado pelo responsável legal.

Diante do exposto, eu declaro que fui convenientemente esclarecido sobre o estudo a ser realizado por Aline Oliveira Silveira e Margareth Angelo e consinto em participar.

A pesquisa terá a duração de um ano. Durante este período, caso necessite de informações adicionais ou decidir pela retirada do consentimento e que os dados não sejam mais utilizados, entrar em contato com as pesquisadoras responsáveis, Margareth Angelo, pelo telefone: 3061-7610 e Aline Oliveira Silveira, pelo telefone 3735-9639.

(Este documento possui duas vias, uma ficará em posse do entrevistado e a outra será arquivada com a pesquisadora).

São Paulo, de de

\footnotetext{
${ }^{1}$ Comitê de Ética em Pesquisa do Hospital Universitário da Universidade de São Paulo (HU-USP). Endereço: Av. Prof. Lineu Prestes, 2565 - Cidade Universitária - CEP: 05508-000 - São Paulo - SP. Telefone: 3091-9457 - Fax: 3091-9452 - E-mail: cep@hu.usp.br
} 
ANEXO 3 - Ficha da Família

\section{(1)Identificação da Família}

Nome da Família:

Endereço:

Telefone:

Membros da Família Presentes na Entrevista:

Local e Data da Entrevista:

(2) Problema de Saúde da Criança e História Pertinente:

(3) Genograma da Família: (nomes, idades, posição na família, atividades e outros dados significativos como: doença familiar, óbito, aborto, adoção, casamento, divórcio)

Avós

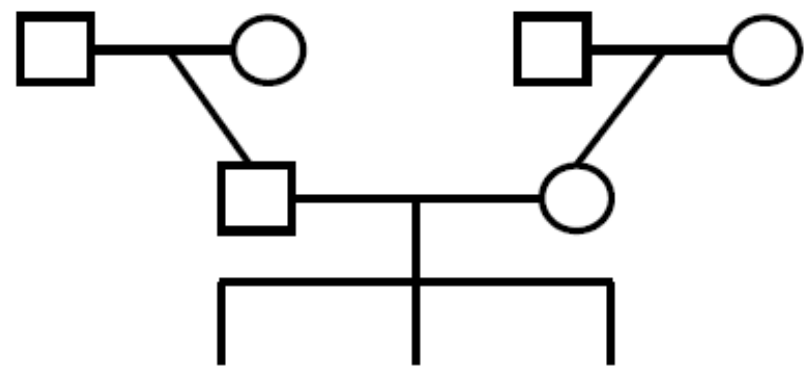

Filhos

(4) Ecomapa da Família (relações significativas entre os subsistemas familiares, família extensa e sistemas mais amplos)

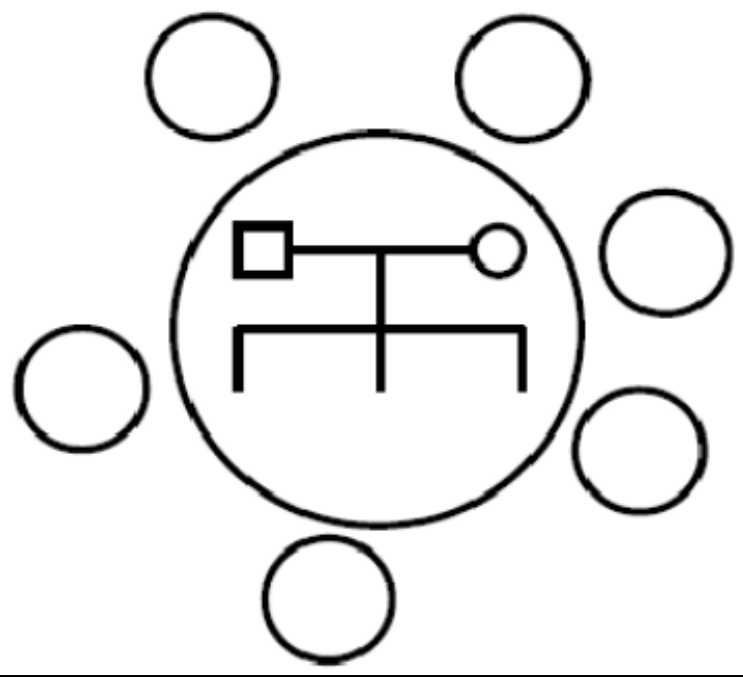

